\title{
DISCLAIMER
}

This report was prepared as an account of work sponsored by an agency of the United States Government. Neither the United States Government nor any agency thereof, nor any of their employees, makes any warranty, express or implied, or assumes any legal liability or responsibility for the accuracy, completeness, or usefulness of any information, apparatus, product, or process disclosed, or represents that its use would not infringe privately owned rights. Reference herein to any specific commercial product, process, or service by trade name, trademark, manufacturer, or otherwise does not necessarily constitute or imply its endorsement, recommendation, or favoring by the United States Government or any agency thereof. The views and opinions of authors expressed herein do not necessarily state or reflect those of the United States Government or any agency thereof.

\section{OAK RIDGE \\ NATIONAL LABORATORY \\ INSTITUTIONAL PLAN \\ FY 1984-FY 1989}

DATE PUBLISHED-NOVEMBER 1983

$\begin{array}{ll}\text { Senior Planning Group } & \text { Planning Staff } \\ \text { H. Postma } & \text { F. E. Sharples } \\ \text { C. R. Richmond } & \text { T. D. Anderson } \\ \text { M. W. Rosenthal } & \text { R. H. Dilworth } \\ \text { K. W. Sommerfeld } & \text { K. A. Erb } \\ \text { D. B. Trauger } & \text { E. L. Preston } \\ \text { A. Zucker } & \text { J. W. Roddy }\end{array}$

Contract No. W-7405-eng-26

OAK RIDGE NATIONAL LABORATORY

OPERATED BY

This document is

THE UNION CARBIDE CORPORATION FOR THE DEPARTMENT OF ENERGY

PUBLICLY RELEASABL

3 Steelo

Authorizing Official

Date: $\quad 3-20-07$ 


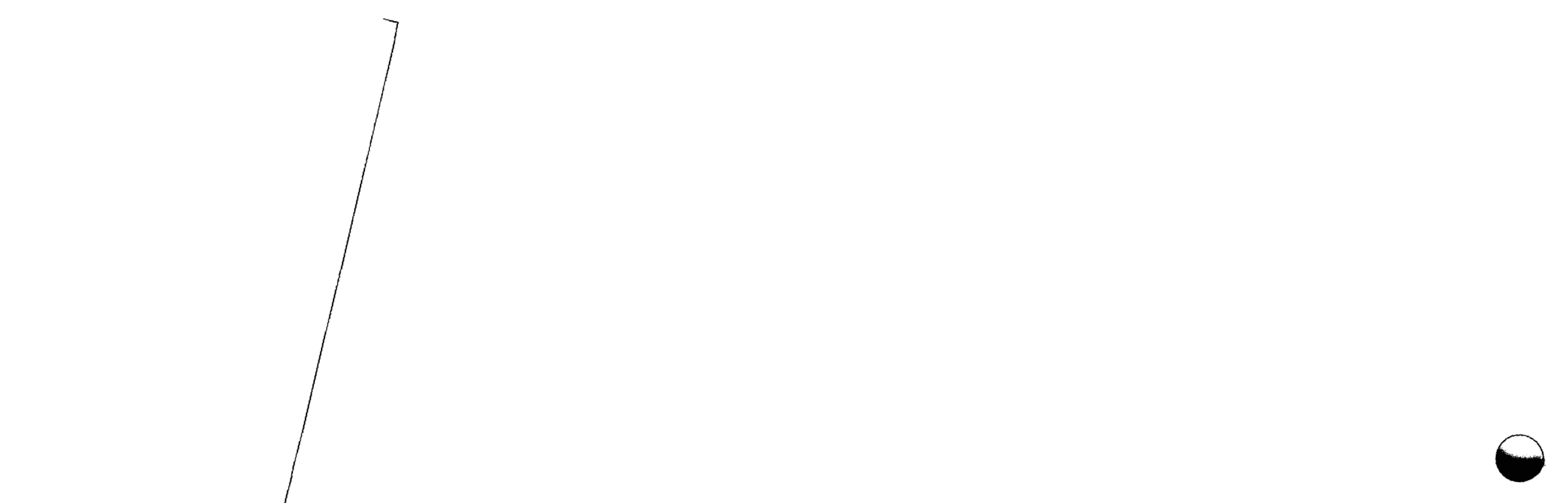




\section{TABLE OF CONTENTS}

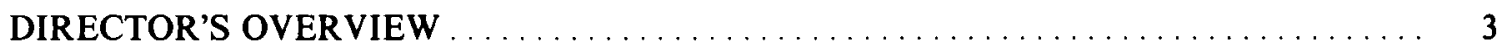

\section{ROLE STATEMENT OF THE OAK RIDGE}

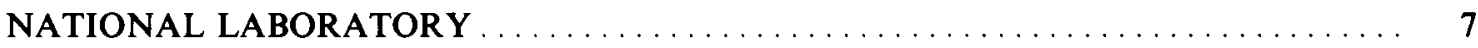

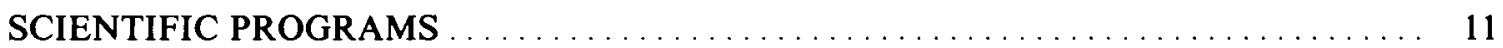

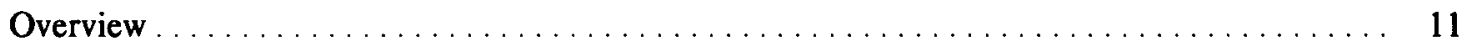

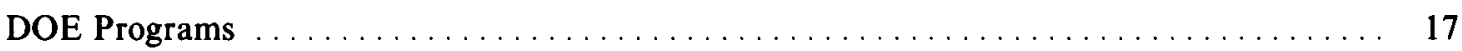

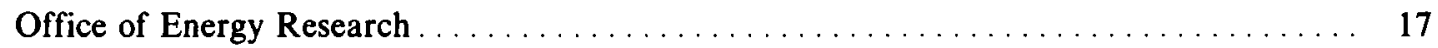

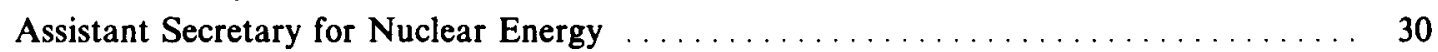

Assistant Secretary for Defense Programs . . . . . . . . . . . . . . . . . . . . . . 37

Assistant Secretary for Conservation and

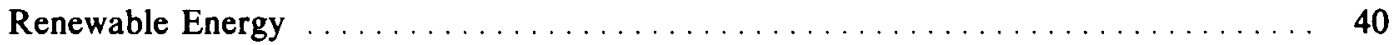

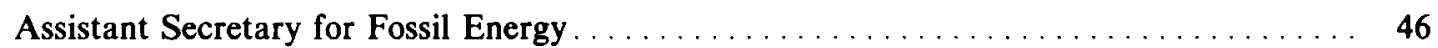

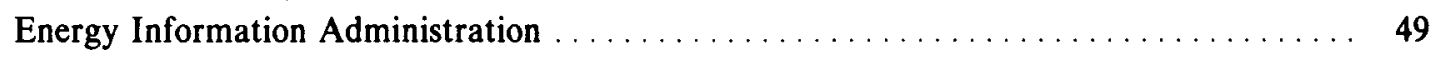

Assistant Secretary for Environmental Protection, Safety, and

Emergency Preparedness .................................. 50

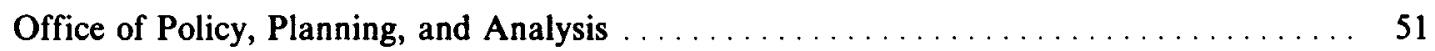

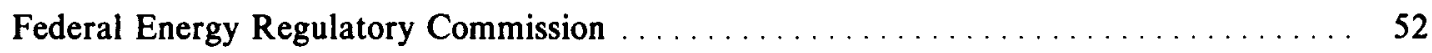

Assistant Secretary for Management and Administration .................. 52

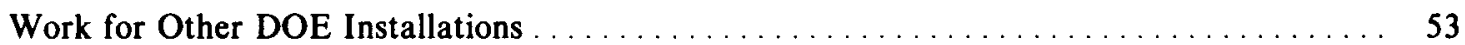

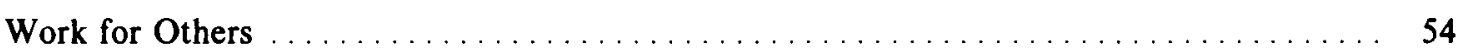

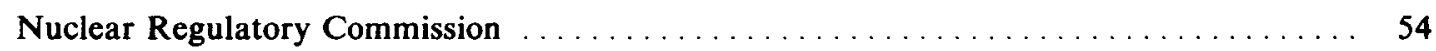

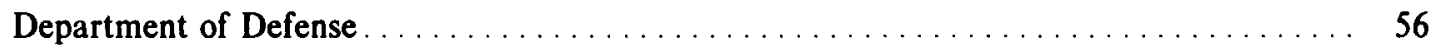

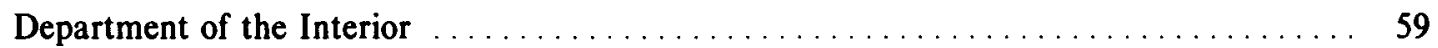

Department of Health and Human Services . . . . . . . . . . . . . . . . . . . . 59

Environmental Protection Agency ........................... 60

National Science Foundation . . . . . . . . . . . . . . . . . . . . . . . . . $\quad 61$

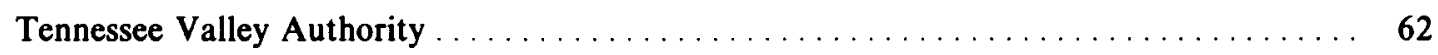

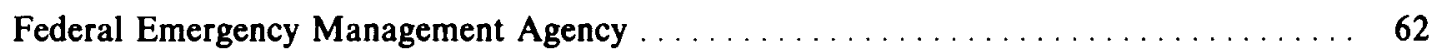

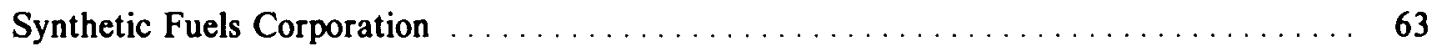

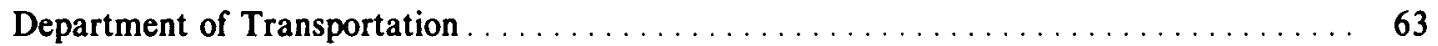

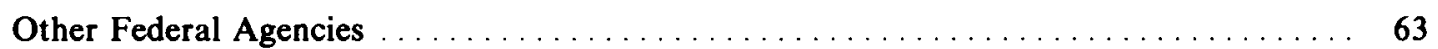

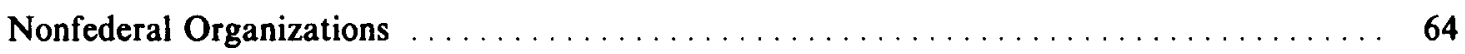

Electric Power Research Institute . . . . . . . . . . . . . . . . . . . . . . . . . . 64

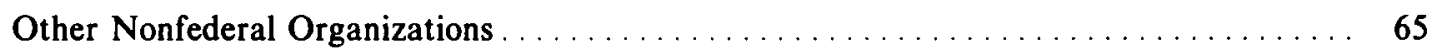


LABORATORY RESOURCE DEVELOPMENT $\ldots \ldots \ldots \ldots \ldots \ldots \ldots \ldots \ldots \ldots \ldots \ldots$

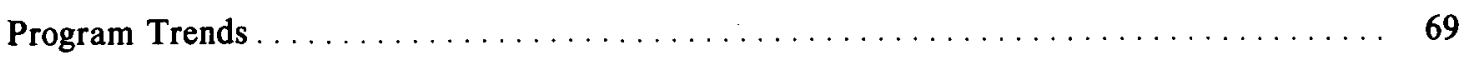

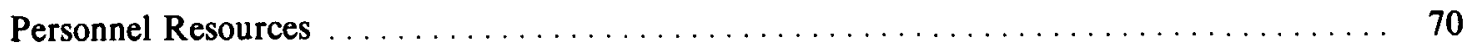

Site Development and Facilities Management $\ldots \ldots \ldots \ldots \ldots \ldots \ldots \ldots \ldots \ldots \ldots \ldots \ldots$

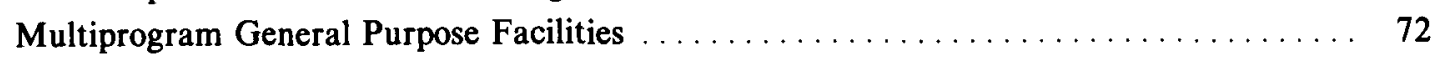

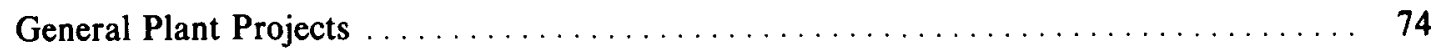

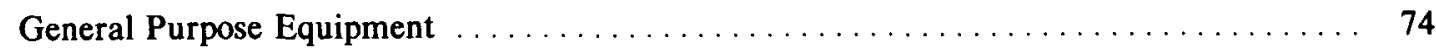

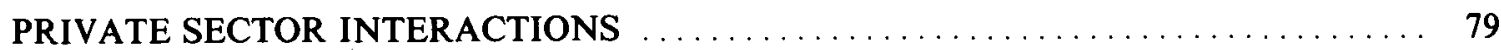

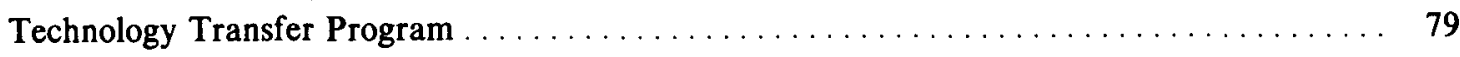

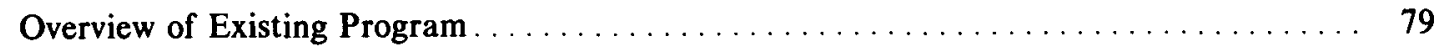

Proposed Expanded Activities: New Initiative

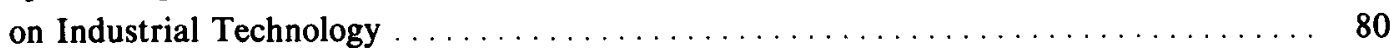

Laboratory Collaborative Research Centers $\ldots \ldots \ldots \ldots \ldots \ldots \ldots \ldots \ldots \ldots \ldots \ldots \ldots$

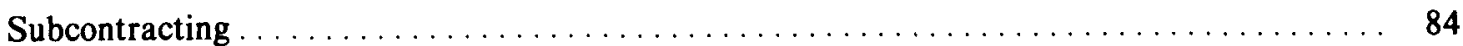

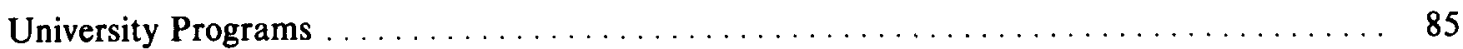

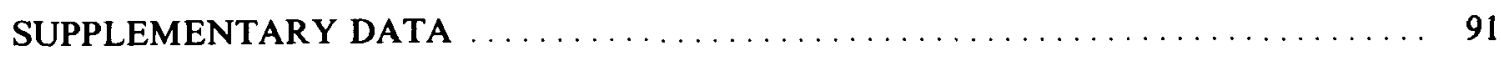

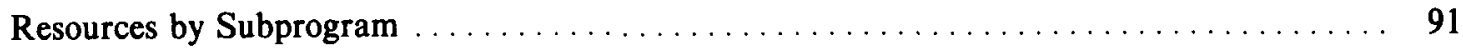

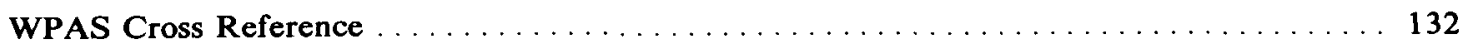

Expenditures on Behalf of Historically Black Colleges $\ldots \ldots \ldots \ldots \ldots \ldots \ldots \ldots \ldots \ldots$

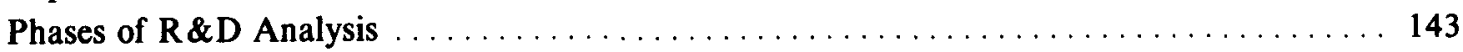




\section{LIST OF ACRONYMS}

AEC

AID

AIM

AMSL

ANL

AR\&TD

ARIM

ASCE

ASDP

ASEP

ASFE

ASMA

ASNE

ATF

AVLIS

BER

BES

BLM

BRET

BTESIM

CAD/CAM

CESAR

CFRP

CRBR

DHHS

DOD

DOE

DOI

DOT

EBT

EBT-P

EBT-S

EEDB

EIA

EPA

EPRI
Atomic Energy Commission

Agency for International Development

Accelerator Improvement and Modification

Analytical Mass Spectrometry Laboratory

Argonne National Laboratory

Advanced Research and Technology Development

Accelerator and Reactor Improvement and Modification

Assistant Secretary for Conservation and Renewable Energy

Assistant Secretary for Defense Programs

Assistant Secretary for Environmental Protection, Safety, and Emergency

Preparedness

Assistant Secretary for Fossil Energy

Assistant Secretary for Management and Administration

Assistant Secretary for Nuclear Energy

Advanced Toroidal Facility

Atomic Vapor Laser Isotope Separation

Building Equipment Research

Basic Energy Sciences

Bureau of Land Management

Breeder Reprocessing Engineering Test

Building Thermal Envelope Systems and Insulating Materials

computer-aided drafting/computer-aided manufacturing

Center for Engineering Systems Advanced Research

Consolidated Fuel Reprocessing Program

Clinch River Breeder Reactor

Department of Health and Human Services

Department of Defense

Department of Energy

Department of the Interior

Department of Transportation

Elmo Bumpy Torus

EBT-proof-of-principle

EBT-scale

Energy Economic Data Base

Energy Information Administration

Environmental Protection Agency

Electric Power Research Institute 


\begin{tabular}{|c|c|}
\hline ERAB & Energy Research Advisory Board \\
\hline ETP & Emergency Technology Program \\
\hline FBC & fluidized-bed combustion \\
\hline FDA & Food and Drug Administration \\
\hline FEDC & Fusion Engineering Design Center \\
\hline FEMA & Federal Emergency Management Agency \\
\hline FERC & Federal Energy Regulatory Commission \\
\hline FFTF & Fast Flux Test Facility \\
\hline FTE & full-time equivalent \\
\hline GCEP & Gas Centrifuge Enrichment Program \\
\hline GPE & General Purpose Equipment \\
\hline GPP & General Plant Project \\
\hline $\mathrm{HBCU}$ & historically black colleges and universities \\
\hline HEDL & Hanford Engineering Development Laboratory \\
\hline HFIR & High Flux Isotope Reactor \\
\hline HHIRF & Holifield Heavy Ion Research Facility \\
\hline HPRR & Health Physics Research Reactor \\
\hline HTGR & high-temperature gas-cooled reactor \\
\hline HTML & High Temperature Materials Laboratory \\
\hline IAEA & International Atomic Energy Agency \\
\hline IDB & Integrated Data Base \\
\hline IET & Integrated Equipment Test \\
\hline INTOR & International Tokamak Reactor \\
\hline JAERI & Japanese Atomic Energy Research Institute \\
\hline JET & Joint European Torus \\
\hline LCTF & Large Coil Test Facility \\
\hline LLNL & Lawrence Livermore National Laboratory \\
\hline LMFBR & liquid-metal fast-breeder reactor \\
\hline LSSFP & Life Sciences Synthetic Fuels Program \\
\hline LWR & Light-Water Reactor \\
\hline MFTF-B & Mirror Fusion Test Facility \\
\hline MGPF & Multiprogram General Purpose Facilities \\
\hline MIT & Massachusetts Institute of Technology \\
\hline MMS & Minerals Management Service \\
\hline NASA & National Aeronautics and Space Administration \\
\hline $\mathrm{NCI}$ & National Cancer Institute \\
\hline NCSASR & National Center for Small Angle Scattering Research \\
\hline NEPA & National Environmental Policy Act \\
\hline NERP & National Environmental Research Park \\
\hline NLM & National Library of Medicine \\
\hline NRC & Nuclear Regulatory Commission \\
\hline NSF & National Science Foundation \\
\hline NSIC & Nuclear Safety Information Center \\
\hline NSLS & National Synchrotron Light Source \\
\hline NTP & National Toxicology Program \\
\hline
\end{tabular}




$\begin{array}{ll}\text { OER } & \text { Office of Energy Research } \\ \text { OHER } & \text { Office of Health and Environmental Research } \\ \text { ORAU } & \text { Oak Ridge Associated Universities } \\ \text { ORELA } & \text { Oak Ridge Electron Linear Accelerator } \\ \text { ORIC } & \text { Oak Ridge Isochronous Cyclotron } \\ \text { ORNL } & \text { Oak Ridge National Laboratory } \\ \text { ORO } & \text { Oak Ridge Operations } \\ \text { ORR } & \text { Oak Ridge Research Reactor } \\ \text { ORTA } & \text { Office of Research and Technology Applications } \\ \text { PIUS } & \text { Process Inherent Ultimate Safety } \\ \text { PPPL } & \text { Princeton Plasma Physics Laboratory } \\ \text { RASCA } & \text { Remedial Action Survey and Certification Activity } \\ \text { RCS } & \text { Residential Conservation Service } \\ \text { rf } & \text { radio frequency } \\ \text { RPI } & \text { Rensselaer Polytechnic Institute } \\ \text { SANS } & \text { small-angle neutron scattering instrument } \\ \text { SAXS } & \text { small-angle x-ray-scattering camera } \\ \text { SCSS } & \text { Sequence Coding and Search System } \\ \text { SFC } & \text { Synthetic Fuels Corporation } \\ \text { SNL } & \text { Sandia National Laboratory } \\ \text { TFTR } & \text { Tokamak Fusion Test Reactor } \\ \text { THORS } & \text { Thermal Hydraulic Out-of-Reactor Safety } \\ \text { TIC } & \text { Technical Information Center } \\ \text { TVA } & \text { Tennessee Valley Authority } \\ \text { UCC-ND } & \text { Union Carbide Corporation-Nuclear Division }\end{array}$


DIRECTOR'S OVERVIEW DO NOT MOROFILM
THS PAGE 


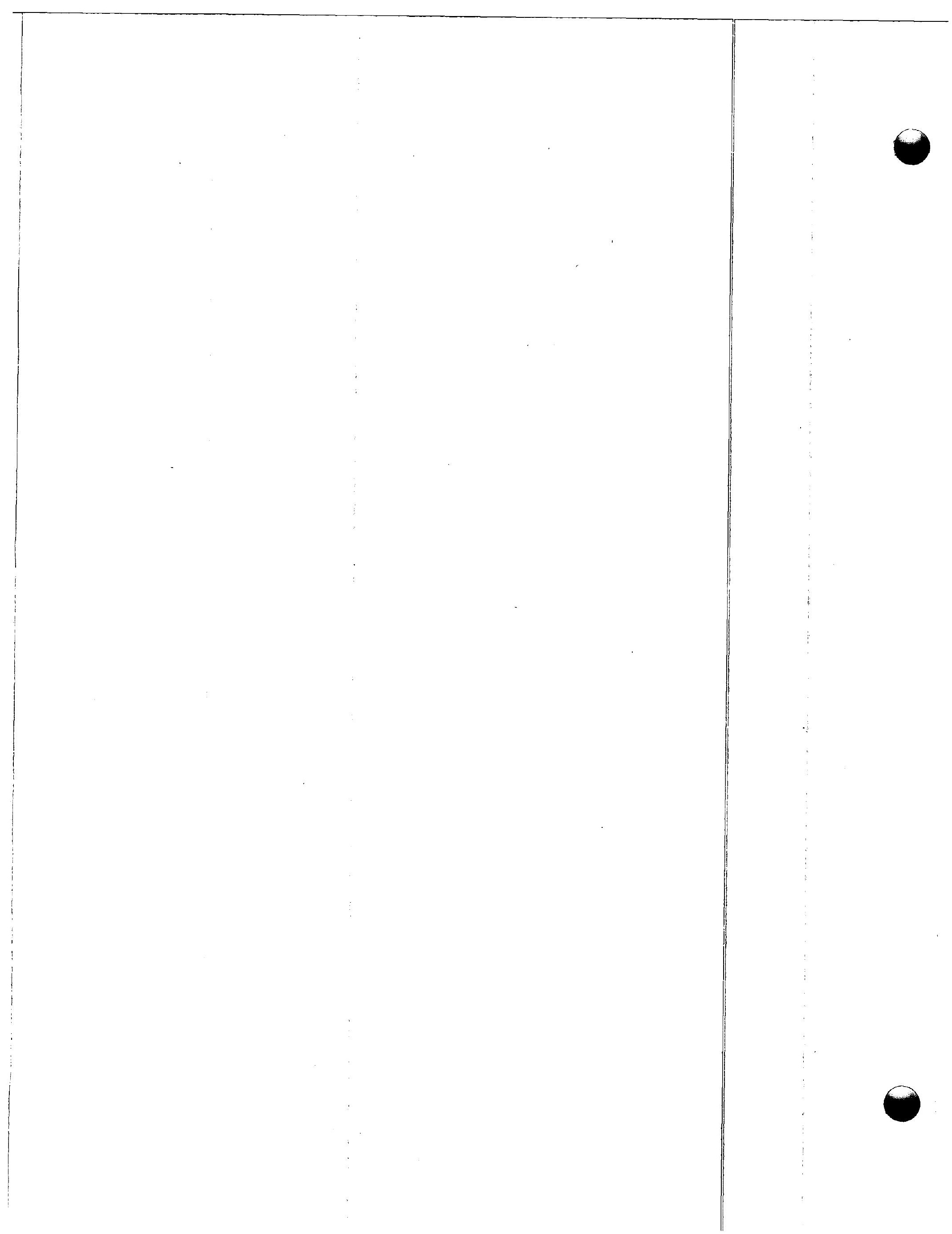




\section{DIRECTOR'S OVERVIEW}

The primary indicator of an Administration's science policy is its research and development (R\&D) budget and particularly its incremental changes. In what is still very much an austere budget climate, $R \& D$ is scheduled this year to receive a very healthy increase in overall funding-amounting to about $13.5 \%$ after inflation. Although much of this increase will be dedicated to defense work, the basic research component of nondefense $R \& D$ will also receive a substantial boost. The FY 1984 budget explicitly favors basic research in the physical sciences, mathematics, and engineering. Thus, the general picture for R\&D funding, as represented by the Administration's budget, is an upbeat one. The FY 1984 budget is a reflection of the growing national consensus that scientific research is the essential underpinning for the technological innovation that is our best hope for breaking the cycle of economic stagnation.

Because of these factors and additional positive reviews of the Department of Energy (DOE) laboratories this year, it is exciting to be a part of the system during a time of reaffirmation of the importance of national scientific and technological resources. The mounting support for a more concerted effort to encourage high-technology development for the sake of the nation's economic future provides us with both an enormous challenge and an enormous opportunity. In this plan, Oak Ridge National Laboratory (ORNL) continues to be committed to scientific and technological research that is based on technical excellence and innovation and that provides a foundation for and a stimulus to broader and more sustained economic growth. We are asking DOE to assist us in establishing a new program for Laboratory cooperation with industry, beginning with an initial focus on materials science, an area which is both one of traditional ORNL expertise and which the Administration has identified as among the top priorities for economic revitalization. The current Institutional Plan thus projects growth in the materials science area as well as in other basic physical science areas and suggests a new initiative designed to extend all of our various technology transfer activities and to make them more effective by using ORNL as the trial Laboratory for some of these different approaches.

On the other hand, the emphasis in Washington has been shifting away from support for other important scientific fields. For example, the increases in R\&D funding in the physical sciences comes at the expense of areas such as the life sciences. The trend in support for biomedical and environmental research has been downward for the last several years. At ORNL many years have been spent in building substantial basic research endeavors in the energy-related life sciences disciplines. The recent history of funding reductions of more than $30 \%$ has substantially weakened many ongoing projects, compromised our ability to perform work in well-established programs, and resulted in the complete elimination of some important program elements. Clarification of where the emphasis will be in DOE's long-range commitment to biological and environmental research and its relation to the energy mission is urgently needed. Without major guidance from DOE, significant questions about the maintenance of a unique and experienced research staff and of important facilities cannot be effectively resolved. 
ORNL would like to see the recommendation of the Energy Research Advisory Board (ERAB) that Congress adopt a rolling two-year appropriation for energy $R \& D$ actually implemented, and ORNL supports the Secretary's efforts to do so. Nevertheless, we also recognize that the sluggish condition of the national economy and the enormous federal budget deficits projected for this year and future years will continue to have an impact on ORNL. Based on this recognition, this Institutional Plan projects a stable future for ORNL-with only modest amounts of growth in selected areas of research for the FY 1984-FY 1989 planning cycle. Tables 1 and 2 provide summaries of the overall picture of the proposed budget and personnel levels for the current planning cycle.

Table 1. Laboratory funding summary"

\begin{tabular}{|c|c|c|c|c|c|c|c|c|c|c|c|c|c|c|c|c|}
\hline \multirow{2}{*}{ ( $\$$ in Millions) } & \multicolumn{2}{|c|}{ FY 1982} & \multicolumn{2}{|c|}{ FY 1983} & \multicolumn{2}{|c|}{ FY 1984} & \multicolumn{2}{|c|}{ FY 1985} & \multicolumn{2}{|c|}{ FY 1986} & \multicolumn{2}{|c|}{ FY 1987} & \multicolumn{2}{|c|}{ FY 1988} & \multicolumn{2}{|c|}{ FY 1989} \\
\hline & BA & BO & BA & BO & $\mathbf{B A}$ & BO & BA & BO & BA & BO & BA & BO & BA & BO & BA & BO \\
\hline DOE Effort & 269.7 & 273.9 & 268.6 & 269.9 & 278.7 & 288.8 & 341.4 & 313.1 & 316.0 & 315.4 & 315.9 & 315.1 & 316.6 & 316.0 & 318.4 & 317.8 \\
\hline Work for Others & 55.9 & 54.1 & 56.4 & 58.7 & 79.6 & 76.4 & 85.0 & 78.2 & 85.8 & 83.1 & 86.1 & 84.7 & 85.6 & 85.7 & 84.8 & 85.4 \\
\hline Total Operating & 325.6 & 328.0 & 325.0 & 328.6 & 358.3 & 365.2 & 426.4 & 391.3 & 401.8 & 398.5 & 402.0 & 399.8 & 402.2 & 401.7 & 403.2 & 403.2 \\
\hline Capital Equipment & 22.2 & & 23.7 & & 24.8 & & 35.3 & & 24.6 & & 24.4 & & 24.1 & & 24.3 & \\
\hline \multicolumn{17}{|l|}{ Program Construction } \\
\hline Funded/budgeted & 27.9 & & 5.0 & & 13.6 & & 9.0 & & 2.6 & & & & & & & \\
\hline Proposed $^{b}$ & 0.0 & & 3.5 & & 5.6 & & 11.1 & & 18.2 & & 36.2 & & 8.5 & & 3.5 & \\
\hline \multicolumn{17}{|l|}{ General Purpose } \\
\hline Facilities & & & & & & & & & & & & & & & & \\
\hline Funded & 2.6 & & 3.6 & & 4.7 & & 0.9 & & & & & & & & & \\
\hline Budgeted/proposed & & & & & 1.8 & & 6.0 & & 18.1 & & 47.4 & & 34.0 & & 27.0 & \\
\hline $\begin{array}{l}\text { General Plant } \\
\text { Projects }\end{array}$ & 4.3 & & 3.5 & & 4.2 & & 9.0 & & 14.0 & & 20.0 & & 21.0 & & 21.0 & \\
\hline General Purpose & 3.3 & & 4.0 & & 4.4 & & 4.7 & & 6.0 & & 7.5 & & 8.0 & & 8.0 & \\
\hline $\begin{array}{l}\text { Total Laboratory } \\
\text { funding }\end{array}$ & 387.4 & & 368.3 & & 417.4 & & 502.4 & & 485.3 & & 537.5 & & 497.8 & & 487.0 & \\
\hline
\end{tabular}

${ }^{\circ}$ An $8.5 \%$ inflation factor has been used between FY 1983 and FY 1984 and between FY 1984 and FY 1985. FY 1986-FY 1989 amounts are in constant FY 1985 dollars.

${ }^{b}$ Includes Waste Management General Plant Projects (GPPs) and Energy Conservation GPPs.

Table 2. Laboratory personnel summary

\begin{tabular}{lrrrrrrrr}
\hline (in FTEs ${ }^{a}$ ) & FY 1982 & FY 1983 & FY 1984 & FY 1985 & FY 1986 & FY 1987 & FY 1988 & FY 1989 \\
\hline Direct & & & & & & & & \\
$\quad$ DOE Effort & 1662.9 & 1578.9 & 1562.7 & 1600.1 & 1622.5 & 1643.3 & 1653.2 & 1665.6 \\
Work for Others & 451.0 & 378.6 & 455.9 & 451.8 & 462.9 & 458.0 & 454.7 & 450.7 \\
$\quad$ Isotopes & 54.0 & 43.0 & 44.0 & 45.0 & 45.0 & 45.0 & 45.0 & 45.0 \\
$\quad$ Total Direct & 2167.9 & 2000.5 & 2062.6 & 2096.9 & 2130.4 & 2146.3 & 2152.9 & 2161.3 \\
Indirect & 2557.1 & 2442.5 & 2516.4 & 2558.2 & 2599.1 & 2618.5 & 2626.5 & 2636.8 \\
$\quad$ Total Laboratory & 4725.0 & 4443.0 & 4579.0 & 4655.1 & 4729.5 & 4764.8 & 4779.4 & 4798.1 \\
$\quad$ personnel & & & & & & & & \\
\hline
\end{tabular}

${ }^{a}$ FTEs $=$ full-time equivalents. 


\section{ROLE STATEMENT OF THE OAK RIDGE NATIONAL LABORATORY}

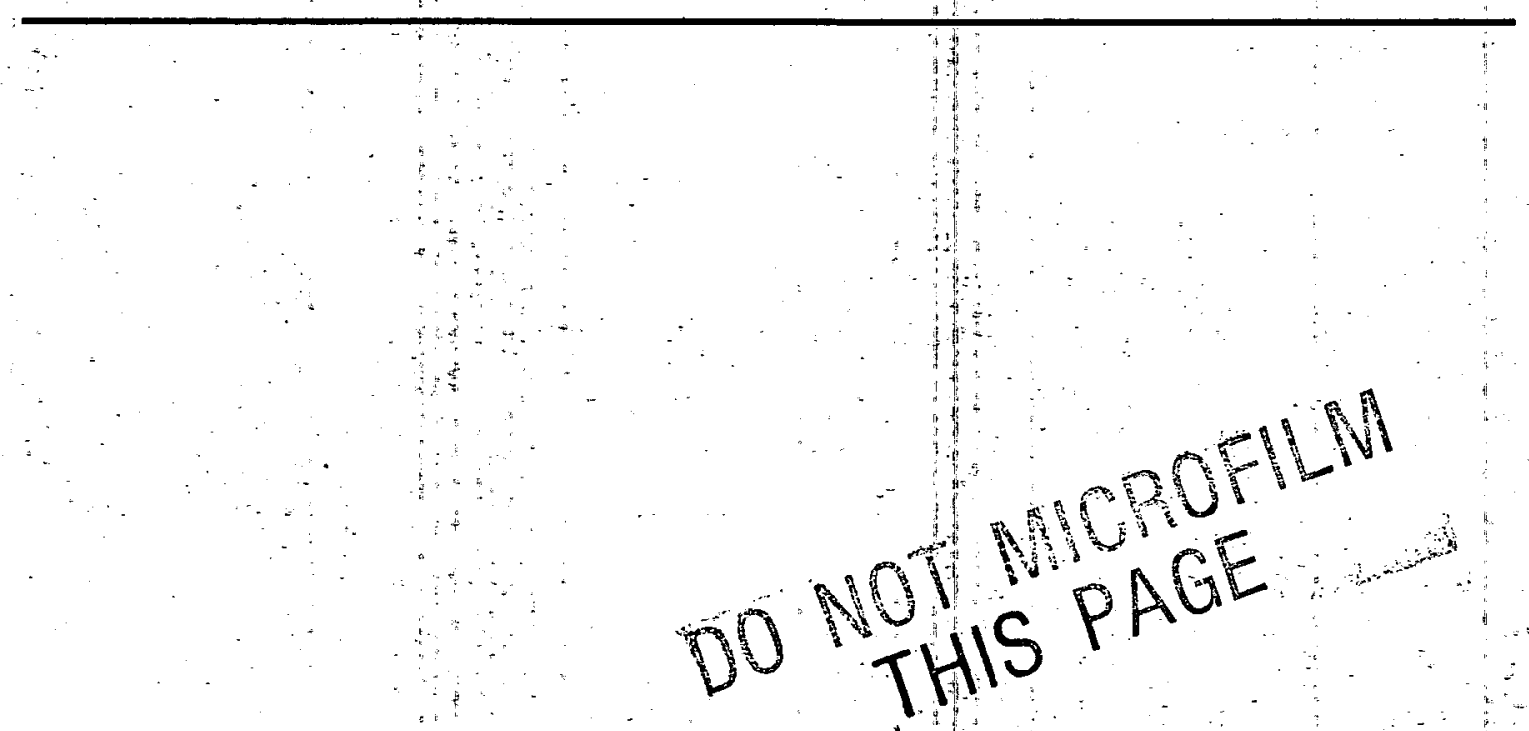




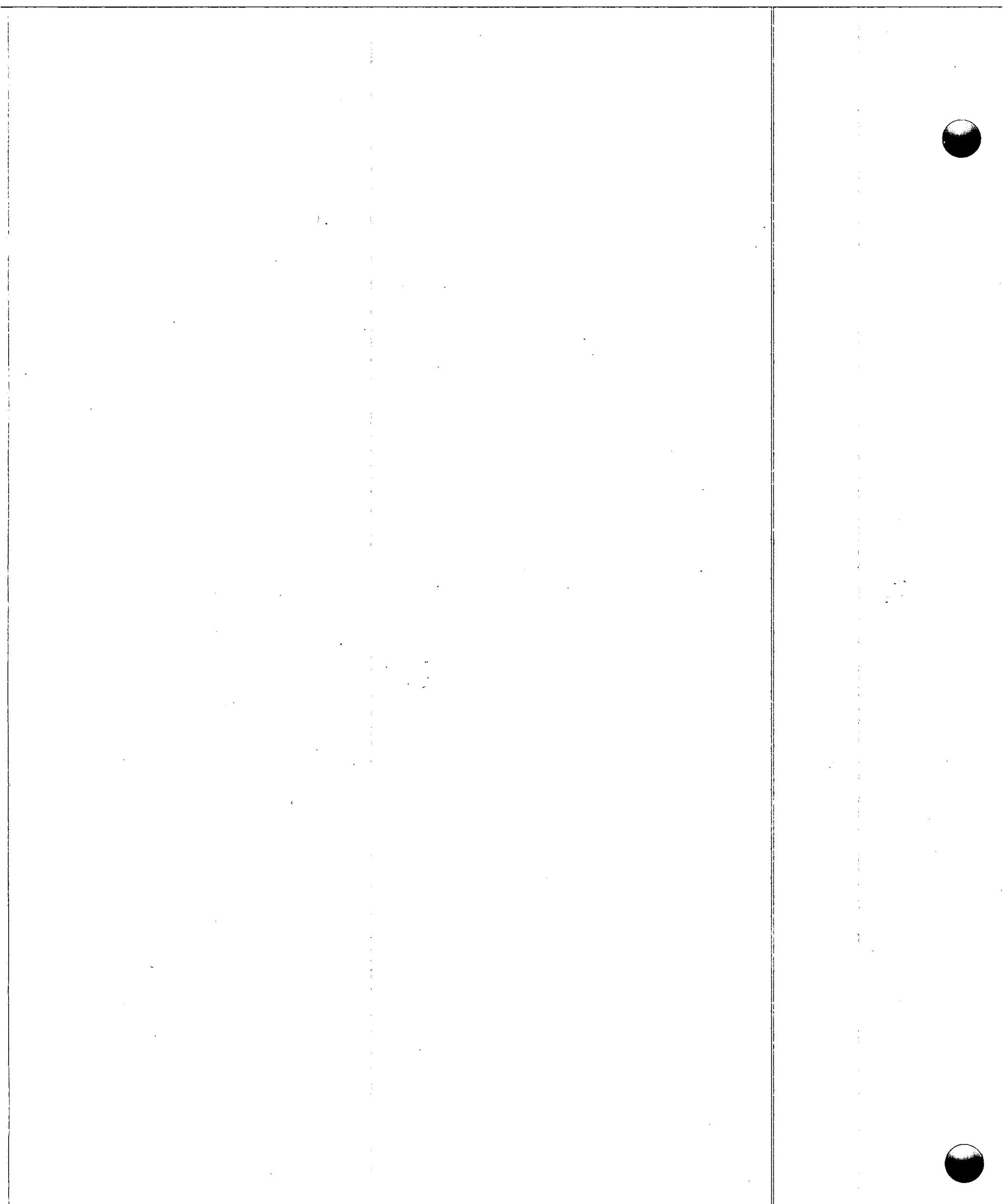




\section{ROLE STATEMENT OF THE OAK RIDGE NATIONAL LABORATORY}

The primary role of ORNL is to conduct R\&D in support of the objectives of DOE. Our major efforts are devoted to the performance of scientific research and technology development for fission and fusion energy. Although the nuclear fields represent the largest share of ORNL's endeavors, the Laboratory also makes important contributions in other areas of energy $R \& D$, such as fossil energy and conservation. The scope of our activities also includes basic and applied research in the physical and life sciences and generating technical and scientific data (e.g., energy-related health, safety, and environmental data) that are broadly needed in the national energy R\&D effort. The emphasis is on high-risk, high-payoff technology development and scientific research that are nationally important but that are not appropriate for the private sector or universities to undertake.

The philosophy of reinforcing fundamental thrusts in a few, well-chosen technologies (multiprogram) with broad, long-term, and more basic research in a variety of pertinent disciplines (multidiscipline) characterizes ORNL as a multiprogram Laboratory. ORNL's role as a performer of R\&D is also broadened by virtue of the Laboratory's stewardship of many unique or rare national research facilities and resources. These include reactors, animal research laboratories, heavy-ion facilities, and the National Environmental Research Park.

In addition to DOE activities, ORNL also does work for other federal agencies and, to a lesser extent, for state and local governments and for the private sector. This "Work for Others" is conducted in areas where the Laboratory has special expertise or facilities and where the work is consistent with DOE program interests. Work for the U.S. Nuclear Regulatory Commission (NRC) constitutes the single largest non-DOE effort, but a significant amount of work is done for other agencies such as the Department of Health and Human Services (DHHS) and the Environmental Protection Agency (EPA). The Work for Others component amounts to about $20 \%$ of the Laboratory's programs.

A significant non-R\&D role performed by ORNL is the manufacture and sale of radioactive and stable isotopes that are not available from the private sector. The Laboratory is a major national source of radioactive and stable isotopes, which are distributed for use by the medical, industrial, and research communities.

ORNL expends special effort to transfer technology to the private sector; to involve industry, where appropriate, in ORNL programs; and to encourage cooperative uses of facilities, both formally in users' groups and informally through professional contacts and participation. Similarly, ORNL provides universities with ready access to major research facilities and programs. At ORNL, university guests may use state-of-the-art research capabilities and training facilities for faculty and students and may participate in collaborative research by using facilities and techniques that are not otherwise available to universities. 
Finally, ORNL plays a special regional role for energy-related activities in the southeastern United States by supporting and collaborating with other institutions-state and local governments and organizations such as the Tennessee Valley Authority (TVA) - that are primary R\&D influences in the area. ORNL is also linked to and supports other DOE-sponsored development activities in the area, such as the Clinch River Breeder Reactor, the uranium enrichment programs, and DOE's Oak Ridge Operations Office. 


\section{VA SIHI W7HOUOWN LON Od}

\section{SWVYDOXd DIHILNĞIDS}




\section{SCIENTIFIC PROGRAMS}

\section{OVERVIEW}

Since 1979 DOE's Office of Energy Research (OER) has been our largest single supporter. Since DOE's 1981 reorganization, this office has been funding over $40 \%$ of our total effort (Fig. 1). The Director of OER also has overall responsibility for the Laboratory. The Office of the Assistant Secretary for Nuclear Energy, the Office of the Assistant Secretary for Defense Programs (which funds ORNL's defense waste work), the Office of the Assistant Secretary for Conservation and Renewable Energy, and the Office of the Assistant Secretary for Fossil Energy also support large efforts at the Laboratory.

The major areas of work at ORNL are in fission energy, magnetic fusion, basic physical sciences, biological and environmental sciences, conservation, and fossil energy (Figs. 2 and 3). Most of these areas are supported by several sources including both DOE and non-DOE organizations. For example, in 1983 ORNL's fission funding came from the Assistant Secretary for Nuclear Energy, NRC, the Assistant Secretary for Defense Programs (for our defense waste work), and other sources.

Numerous non-DOE sponsors currently fund the work of almost $20 \%$ of the Laboratory's direct full-time equivalents (FTEs) (Fig. 4). Supporting 179 direct FTEs in FY 1983, NRC is our largest non-DOE funding source. Our research support for this agency is mandated by the Energy Reorganization Act of 1974. The second largest non-DOE sponsor is currently the Department of Defense (DOD). While FY 1983 DOD funding supported about 43 direct FTEs, this work is expected to expand to a level of about 97 FTEs by FY 1985. Many of our other non-DOE sponsors, including the EPA and DHHS, fund various life sciences programs at ORNL. The relatively large EPA support has resulted, in part, from transfers of funds from DOE to EPA in 1979.

The Laboratory and DOE have benefited greatly from these non-DOE programs. Through these efforts, we have been able to enter or develop new areas of research that have proven useful to DOE. Non-DOE funding has been particularly valuable in complementing DOE research in the life sciences. Each program from other sponsors is approved by DOE and complements DOE's own programs; thus, DOE receives significant benefit while the Laboratory is able to maintain institutional and programmatic flexibility. The current proportion of non-DOE work is expected to remain about the same throughout the planning cycle.

Summaries of ORNL funding and personnel by assistant secretarial level offices are presented in Tables 3 and 4. 


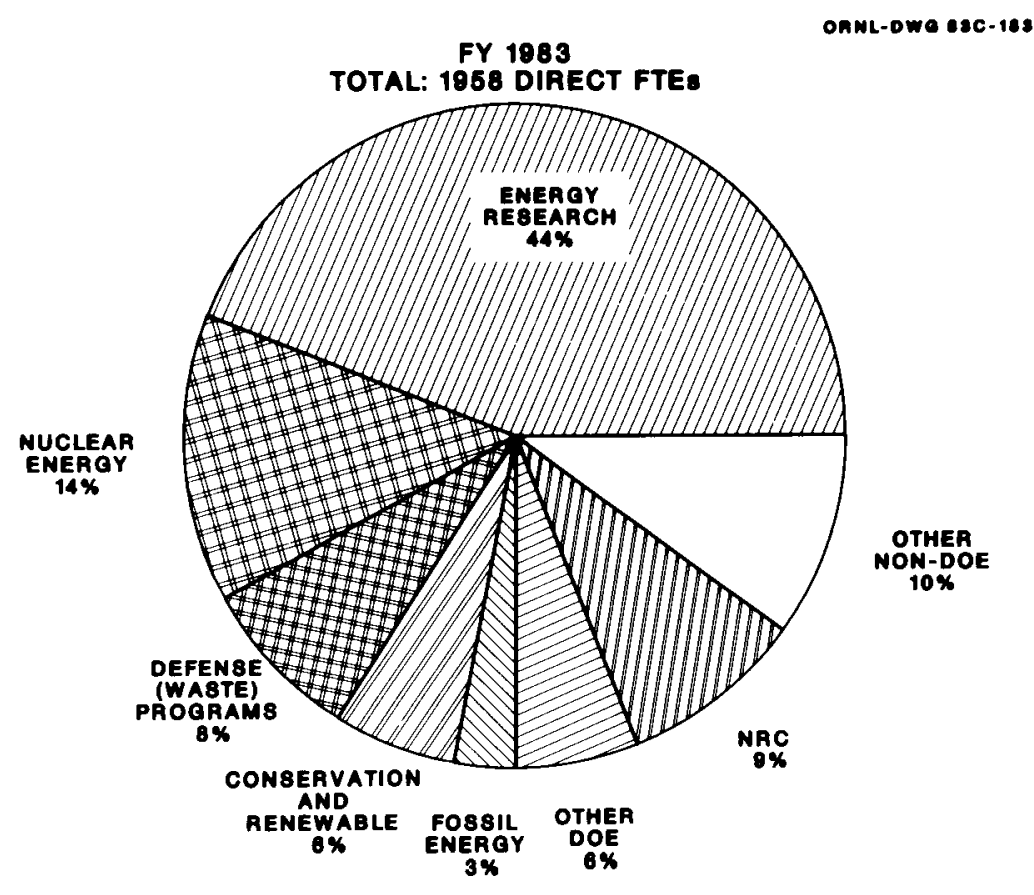

Fig. 1. The OER supports over $40 \%$ of ORNL's direct FTEs. Other major DOE sponsors include the Assistant Secretaries for Nuclear Energy, Defense Waste Programs, Conservation and Renewable Energy, and Fossil Energy.

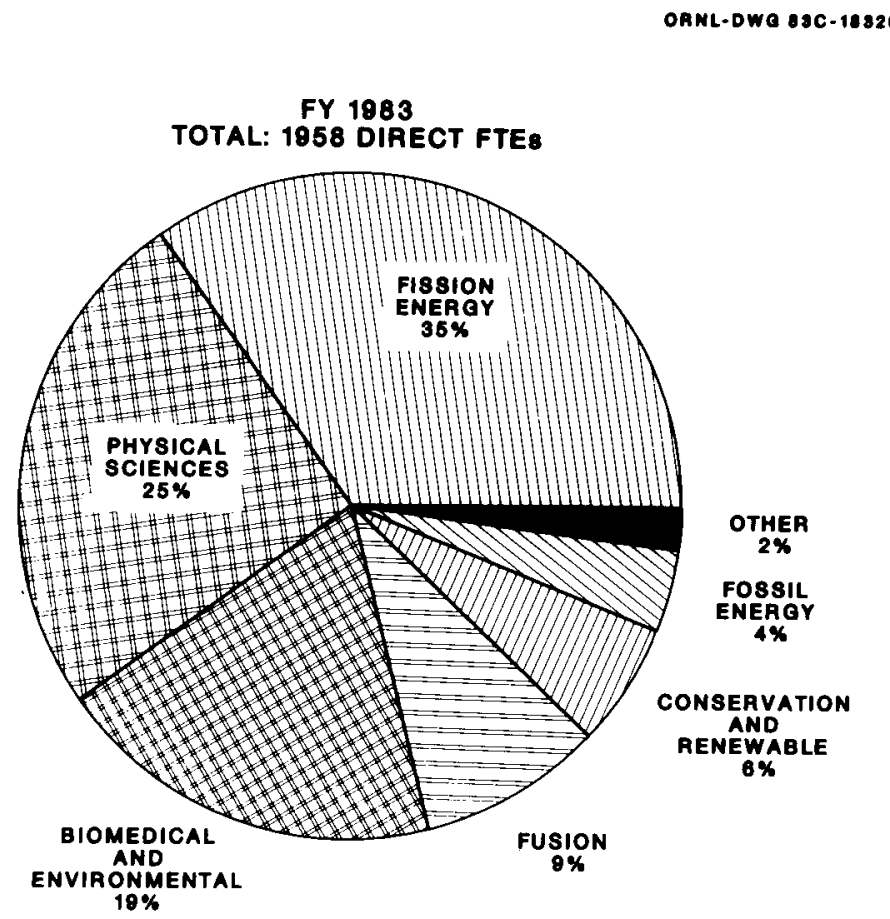

Fig. 2. As a percentage of FTEs, Fission Energy is the largest ORNL program area, but large efforts are carried out in many other areas. (These program areas are defined internally by ORNL and do not necessarily correspond directly with DOE's program structure.) 
FY 1883

TOTAL: \$328 MILLION

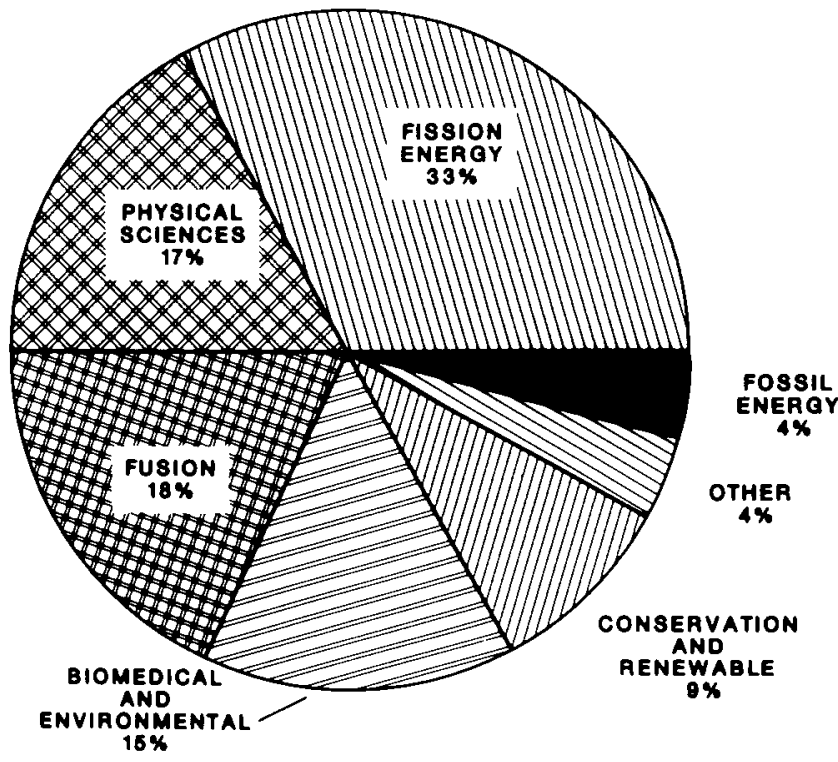

Fig. 3. The distribution of ORNL's operating budget is similar to the distribution of personnel except in areas (e.g., the Fusion and the Conservation programs) where considerable funding is spent outside the Laboratory.

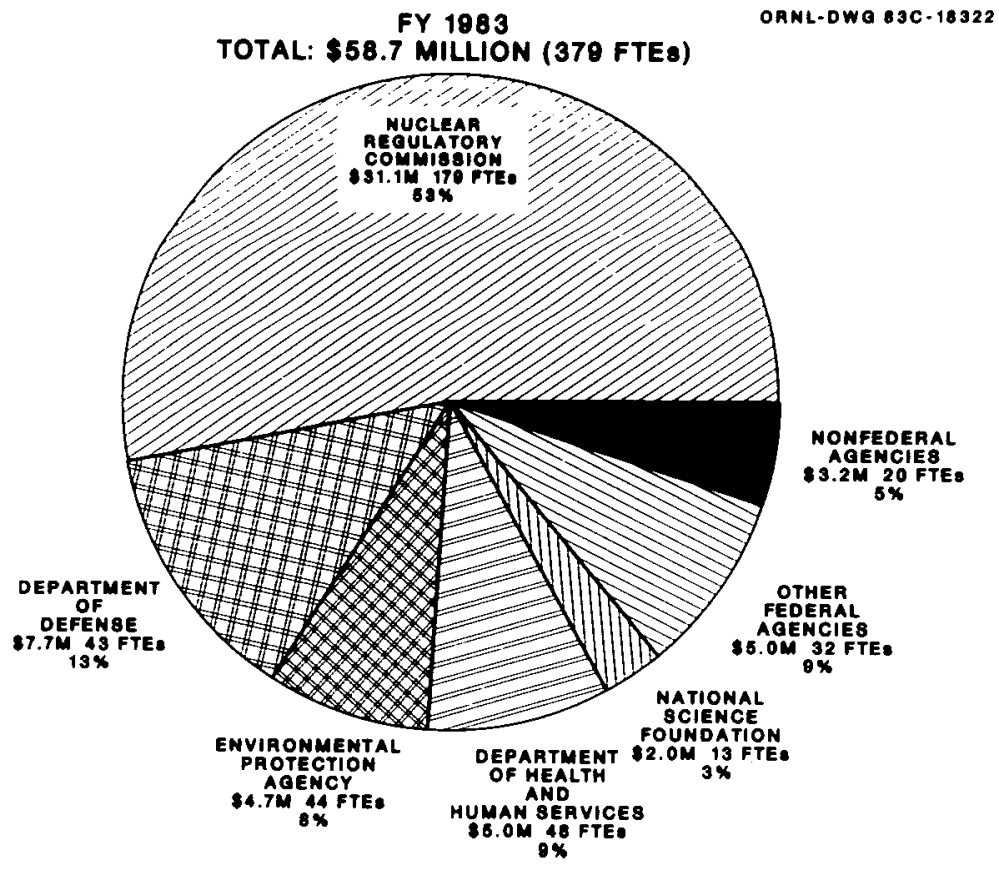

Fig. 4. NRC sponsors about one-half of ORNL's non-DOE work. 
Table 3. Funding by assistant secretarial level office

\begin{tabular}{|c|c|c|c|c|c|c|c|c|c|c|c|c|c|c|}
\hline \multirow{2}{*}{ ( $S$ in Millions) } & \multicolumn{2}{|c|}{ FY 1983} & \multicolumn{2}{|c|}{ FY $1984^{a}$} & \multicolumn{2}{|c|}{ FY $1985^{a}$} & \multicolumn{2}{|c|}{ FY $1986^{b}$} & \multicolumn{2}{|c|}{ FY $1987^{b}$} & \multicolumn{2}{|c|}{ FY $1988^{b}$} & \multicolumn{2}{|c|}{ FY $1989^{b}$} \\
\hline & BA & BO & BA & BO & BA & BO & BA & BO & BA & BO & BA & BO & $\mathbf{B A}$ & BO \\
\hline \multicolumn{15}{|l|}{ Assistant Secretary for } \\
\hline Total Operating & 9.0 & 10.2 & 9.8 & 10.7 & 16.5 & 15.1 & 16.6 & 16.6 & 16.6 & 16.6 & 16.6 & 16.6 & 16.6 & 16.6 \\
\hline Capital Equipment & 0.1 & & 0.5 & & 0.6 & & 0.7 & & 0.7 & & 0.7 & & 0.7 & \\
\hline Total Asst. Secretary & 9.2 & & 10.3 & & 17.1 & & 17.3 & & 17.3 & & 17.3 & & 17.3 & \\
\hline \multicolumn{15}{|l|}{ Assistant Secretary for } \\
\hline Total Operating & 42.8 & 45.5 & 51,4 & 49.9 & 53.6 & 52.6 & 55.3 & 54.5 & 58.0 & 57.4 & 58.5 & 58.3 & 59.2 & 59.0 \\
\hline Capital Equipment & 5.1 & & 6.5 & & 12.3 & & 5.4 & & 5.5 & & 5.2 & & 5.4 & \\
\hline Total Asst. Secretary & 47.9 & & 57.9 & & 65.9 & & 60.6 & & 63.5 & & 63.7 & & 64.6 & \\
\hline \multicolumn{15}{|l|}{ Assistant Secretary for } \\
\hline \multirow{2}{*}{\multicolumn{15}{|c|}{$\begin{array}{l}\text { Conservation and } \\
\text { Renewable Energy }\end{array}$}} \\
\hline & & & & & & & & & & & & & & \\
\hline Total Operating & 27.1 & 28.0 & 32.0 & 34.1 & 33.0 & 33.5 & 34.8 & 35.1 & 34.8 & 34.8 & 34.8 & 34.8 & 34.8 & 34.8 \\
\hline Capital Equipment & 1.4 & & 1.6 & & 1.4 & & 0.4 & & 0.4 & & 0.4 & & 0.4 & \\
\hline Construction & 0.0 & & 9.0 & & 9.0 & & 2.6 & & 0.0 & & 0.0 & & 0.0 & \\
\hline Total Asst. Secretary & 28.5 & & 42.6 & & 43.4 & & 37.9 & & 35.3 & & 35.3 & & 35.3 & \\
\hline \multicolumn{15}{|l|}{$\begin{array}{l}\text { Office of Policy, Planning, } \\
\text { and Analysis }\end{array}$} \\
\hline Total Operating & 0.0 & 0.1 & 0.2 & 0.1 & 0.2 & 0.2 & 0.2 & 0.2 & 0.2 & 0.2 & 0.2 & 0.2 & 0.2 & 0.2 \\
\hline \multicolumn{15}{|l|}{ Office of Energy Research } \\
\hline Total Operating & 147.3 & 141.4 & 144.5 & 151.5 & 190.6 & 165.4 & 168.2 & 167.6 & 169.5 & 169.1 & 170.8 & 170.4 & 172.1 & 171.8 \\
\hline Capital Equipment & 14.4 & & 12.4 & & 16.5 & & 14.9 & & 14.9 & & 14.9 & & 14.9 & \\
\hline Construction & 0.0 & & 0.6 & & 0.0 & & 0.0 & & 0.0 & & 0.0 & & 0.0 & \\
\hline Total Asst. Secretary & 161.8 & & 157.5 & & 207.2 & & 183.2 & & 184.4 & & 185.7 & & 187.1 & \\
\hline \multicolumn{15}{|l|}{$\begin{array}{l}\text { Assistant Secretary } \\
\text { for Defense }\end{array}$} \\
\hline Total Operating & 24.2 & 23.6 & 28.4 & 28.9 & 34.2 & 32.8 & 28.1 & 28.7 & 24.0 & 24.4 & 22.9 & 23.0 & 22.6 & 22.6 \\
\hline Capital Equipment & 1.3 & & 1.5 & & 1.8 & & 1.4 & & 1.1 & & 1.1 & & 1.1 & \\
\hline Construction & 5.0 & & 4.0 & & 0.0 & & 0.0 & & 0.0 & & 0.0 & & 0.0 & \\
\hline Total Asst. Secretary & 30.5 & & 34.0 & & 36.0 & & 29.5 & & 25.1 & & 24.0 & & 23.7 & \\
\hline \multirow{2}{*}{\multicolumn{15}{|c|}{$\begin{array}{l}\text { Assistant Secretary for } \\
\text { Protection, Safety, and } \\
\text { Environmental } \\
\text { Energy Preparation }\end{array}$}} \\
\hline & & & & & & & & & & & & & & \\
\hline Total Operating & 3.5 & 3.8 & 2.4 & 2.3 & 2.8 & 2.8 & 2.8 & 2.8 & 2.8 & 2.8 & 2.8 & 2.8 & 2.8 & 2.8 \\
\hline Capital Equipment & 0.1 & & 0.0 & & 0.1 & & 0.1 & & 0.1 & & 0.1 & & 0.1 & \\
\hline Total Asst. Secretary & 3.6 & & 2.5 & & 2.8 & & 2.8 & & 2.8 & & 2.8 & & 2.8 & \\
\hline \multicolumn{15}{|l|}{ Federal Energy } \\
\hline Total Operating & 0.3 & 0.3 & 0.7 & 0.5 & 0.6 & 0.6 & 0.6 & 0.6 & 0.6 & 0.6 & 0.6 & 0.6 & 0.6 & 0.6 \\
\hline \multicolumn{15}{|l|}{ Energy Information } \\
\hline Total Operating & 0.5 & 4.9 & 1.4 & 2.2 & 2.2 & 2.2 & 2.2 & 2.2 & 2.2 & 2.2 & 2.2 & 2.2 & 2.2 & 2.2 \\
\hline \multicolumn{15}{|l|}{$\begin{array}{l}\text { Assistant Secretary } \\
\text { for Management and } \\
\text { Administration }\end{array}$} \\
\hline Total Operating & 0.9 & 0.9 & 1.1 & 1.0 & 1.2 & 1.2 & 1.3 & 1.2 & 1.3 & 1.3 & 1.4 & 1.3 & 1.4 & 1.4 \\
\hline Capital Equipment & 0.1 & & 0.1 & & 0.1 & & 0.0 & & 0.0 & & 0.0 & & 0.0 & \\
\hline Total Asst. Secretary & 1.0 & & 1.2 & & 1.3 & & 1.3 & & 1.3 & & 1.4 & & 1.4 & \\
\hline $\begin{array}{l}\text { DOE Contractors and } \\
\text { Operations Offices }\end{array}$ & & & & & & & & & & & & & & \\
\hline Total Operating & 12.8 & 11.3 & 6.9 & 7.3 & 6.4 & 6.8 & 5,9 & 5.9 & 5.9 & 5.9 & 5.9 & 5.9 & 5.9 & 5.9 \\
\hline Capital Equipment & 0.1 & & 0.1 & & 0.1 & & 0.1 & & 0.1 & & 0.1 & & 0.1 & \\
\hline Total Program & 12.9 & & 7.0 & & 6.5 & & 6.0 & & 6.0 & & 6.0 & & 6.0 & \\
\hline
\end{tabular}


Table 3 (cootinued)

\begin{tabular}{|c|c|c|c|c|c|c|c|c|c|c|c|c|c|c|}
\hline \multirow{2}{*}{ ( $\$$ in Millions) } & \multicolumn{2}{|c|}{ FY 1983} & \multicolumn{2}{|c|}{ FY $1984^{a}$} & \multicolumn{2}{|c|}{ FY $1985^{a}$} & \multicolumn{2}{|c|}{ FY $1986^{b}$} & \multicolumn{2}{|c|}{ FY $1987^{b}$} & \multicolumn{2}{|c|}{ FY $1988^{b}$} & \multicolumn{2}{|c|}{ FY $1989^{b}$} \\
\hline & BA & BO & BA & BO & BA & BO & BA & BO & BA & BO & BA & BO & BA & BO \\
\hline \multicolumn{15}{|l|}{ Total DOE Programs } \\
\hline Total Operating & 268.6 & 269.9 & 278.7 & 288.8 & 341.4 & 313.1 & 316.0 & 315.4 & 315.9 & 315.1 & 316.6 & 316.0 & 318.4 & 317.8 \\
\hline Capital Equipment & 22.5 & & 22.8 & & 32.8 & & 23.0 & & 22.9 & & 22.5 & & 22.8 & \\
\hline Construction & 5.0 & & 13.6 & & 9.0 & & 2.6 & & 0.0 & & 0.0 & & 0.0 & \\
\hline Total DOE Programs & 296.1 & & 315.1 & & 383.2 & & 341.6 & & 338.8 & & 339.1 & & 341.2 & \\
\hline \multirow{2}{*}{\multicolumn{15}{|c|}{$\begin{array}{l}\text { Nuclear Regulatory } \\
\text { Commission }\end{array}$}} \\
\hline & & & & & & & & & & & & & & \\
\hline Total Operating & 28.9 & 31.1 & 29.6 & 31.7 & 31.4 & 28.9 & 31.5 & 30.8 & 31.3 & 30.9 & 30.8 & 30.9 & 30.2 & 30.9 \\
\hline Capital Equipment & 1.1 & & 0.0 & & 0.0 & & 0.0 & & 0.0 & & 0.0 & & 0.0 & \\
\hline Total Program & 30.0 & & 29.6 & & 31.4 & & 31.5 & & 31.3 & & 30.8 & & 30.2 & \\
\hline \multicolumn{15}{|l|}{ Department of Defense } \\
\hline Total Operating & 7.7 & 7.7 & 20.8 & 15.5 & 25.6 & 21.3 & 26.0 & 24.0 & 26.5 & 25.5 & 26.5 & 26.5 & 26.5 & 26.5 \\
\hline Capital Equipment & 0.1 & & 1.9 & & 2.5 & & 1.6 & & 1.5 & & 1.5 & & 1.5 & \\
\hline Total Program & 7.7 & & 22.7 & & 28.1 & & 27.6 & & 28.0 & & 28.0 & & 28.0 & \\
\hline \multicolumn{15}{|l|}{ Other Federal Agencies } \\
\hline Total Operating & 16.7 & 16.7 & 22.8 & 22.8 & 24.0 & 24.0 & 23.8 & 23.8 & 23.8 & 23.8 & 23.8 & 23.8 & 23.6 & 23.6 \\
\hline \multicolumn{15}{|l|}{ Nonfederal Agencies } \\
\hline Total Operating & 3.2 & 3.2 & 6.4 & 6.4 & 4.0 & 4.0 & 4.5 & 4.5 & 4.5 & 4.5 & 4.5 & 4.5 & 4.5 & 4.5 \\
\hline \multicolumn{15}{|l|}{ Total Work for Others } \\
\hline Total Operating & 56.4 & 58.7 & 79.6 & 76.4 & 85.0 & 78.2 & 85.8 & 83.1 & 86.1 & 84.7 & 85.6 & 85.7 & 84.8 & 85.5 \\
\hline Capital Equipment & 1.2 & & 2.0 & & 2.5 & & 1.7 & & 1.6 & & 1.6 & & 1.6 & \\
\hline $\begin{array}{l}\text { Total Work for Others } \\
\text { Programs }\end{array}$ & 57.6 & & 81.5 & & 87.5 & & 87.5 & & 87.7 & & 87.2 & & 86.4 & \\
\hline General Purpose Facilities & & & & & & & & & & & & & & \\
\hline $\begin{array}{l}\text { Funded, budgeted, and } \\
\text { proposed }\end{array}$ & 3.6 & & 6.5 & & 6.9 & & 18.1 & & 47.4 & & 34.0 & & 27.0 & \\
\hline General Purpose Projects & 3.5 & & 4.2 & & 9.0 & & 14.0 & & 20.0 & & 21.0 & & 21.0 & \\
\hline General Purpose Equipment & 4.0 & & 4.4 & & 4.7 & & 6.0 & & 7.5 & & 8.0 & & 8.0 & \\
\hline $\begin{array}{l}\text { Proposed Program } \\
\text { Construction }\end{array}$ & 3.5 & & 5.6 & & 11.1 & & 18.2 & & 36.2 & & 8.5 & & 3.5 & \\
\hline Total Laboratory Funding & 368.3 & & 417.4 & & 502.4 & & 485.3 & & 537.5 & & 497.8 & & 487.0 & \\
\hline
\end{tabular}

'Escalation factors from FY 1983 to FY 1984 and from FY 1984 to FY 1985 are both 8.5\%.

${ }^{6}$ Figures from FY 1986 through FY 1989 are in constant FY 1985 dollars. 
Table 4. Personnel by assistant secretarial level office

\begin{tabular}{|c|c|c|c|c|c|c|c|}
\hline (in FTEs) & FY 1983 & FY 1984 & FY 1985 & FY 1986 & FY 1987 & FY 1988 & FY 1989 \\
\hline $\begin{array}{l}\text { Assistant Secretary for Fossil Ene } \\
\text { Direct Personnel }\end{array}$ & 51.4 & 47.3 & 62.6 & 69.6 & 69.6 & 69.6 & 69.6 \\
\hline $\begin{array}{l}\text { Assistant Secretary for Nuclear E } \\
\text { Direct Personnel }\end{array}$ & 266.4 & 289.3 & 312.2 & 333.6 & 353.1 & 357.3 & 361.8 \\
\hline $\begin{array}{l}\text { Assistant Secretary for Conservat } \\
\text { and Renewable Energy } \\
\text { Direct Personnel }\end{array}$ & 113.0 & 126.6 & 109.2 & 95.9 & 93.9 & 93.9 & 93.9 \\
\hline $\begin{array}{l}\text { Office of Policy, Planning, and A } \\
\text { Direct Personnel }\end{array}$ & 0.2 & 0.5 & 0.8 & 1.0 & 1.0 & 1.0 & 1.0 \\
\hline $\begin{array}{l}\text { Office of Energy Research } \\
\text { Direct Personnel }\end{array}$ & 862.5 & 867.2 & 885.2 & 900.4 & 913.2 & 924.4 & 935.3 \\
\hline $\begin{array}{l}\text { Assistant Secretary for Defense } \\
\text { Direct Personnel }\end{array}$ & 159.9 & 162.6 & 168.8 & 160.6 & 151.1 & 145.6 & 142.6 \\
\hline $\begin{array}{l}\text { Assistant Secretary for Environm } \\
\text { Protection, Safety, and Energy } \\
\text { Preparedness } \\
\text { Direct Personnel }\end{array}$ & 24.3 & 10.3 & 12.2 & 12.2 & 12.2 & 12.2 & 12.2 \\
\hline $\begin{array}{l}\text { Federal Energy Regulation Comn } \\
\text { Direct Personnel }\end{array}$ & 2.4 & 3.6 & 3.5 & 3.5 & 3.5 & 3.5 & 3.5 \\
\hline $\begin{array}{l}\text { Energy Information Administrati } \\
\text { Direct Personnel }\end{array}$ & 14.5 & 9.0 & 9.0 & 9.0 & 9.0 & 9.0 & 9.0 \\
\hline $\begin{array}{l}\text { Assistant Secretary for Managem } \\
\text { and Administration } \\
\text { Direct Personnel }\end{array}$ & 0.4 & 0.0 & 0.0 & 0.0 & 0.0 & 0.0 & 0.0 \\
\hline $\begin{array}{l}\text { DOE Contractors and Operations } \\
\text { Offices } \\
\text { Direct Personnel }\end{array}$ & 83.9 & 46.3 & 36.6 & 36.7 & 36.7 & 36.7 & 36.7 \\
\hline $\begin{array}{l}\text { Total DOE Programs } \\
\text { Direct Personnel }\end{array}$ & 1578.9 & 1562.7 & 1600.1 & 1622.5 & 1643.3 & 1653.2 & 1665.6 \\
\hline $\begin{array}{l}\text { Nuclear Regulatory Commission } \\
\text { Direct Personnel }\end{array}$ & 179.0 & 180.2 & 166.6 & 175.6 & 173.7 & 170.4 & 167.7 \\
\hline $\begin{array}{l}\text { Department of Defense } \\
\text { Direct Personnel }\end{array}$ & 42.6 & 81.1 & 97.3 & 99.0 & 96.0 & 96.0 & 96.0 \\
\hline $\begin{array}{l}\text { Other Federal Agencies } \\
\text { Direct Personnel }\end{array}$ & 137.3 & 157.0 & 157.4 & 158.4 & 158.4 & 158.4 & 157.1 \\
\hline $\begin{array}{l}\text { Nonfederal Agencies } \\
\text { Direct Personnel }\end{array}$ & 19.7 & 37.6 & 30.5 & 29.9 & 29.9 & 29.9 & 29.9 \\
\hline $\begin{array}{l}\text { Total Work for Others } \\
\text { Direct Personnel }\end{array}$ & 378.6 & 455.9 & 451.8 & 462.9 & 458.0 & 454.7 & 450.7 \\
\hline Isotopes & 43.0 & 44.0 & 45.0 & 45.0 & 45.0 & 45.0 & 45.0 \\
\hline $\begin{array}{l}\text { Total Direct Personnel } \\
\text { Total Indirect Personnel } \\
\text { Total Laboratory Personnel }\end{array}$ & $\begin{array}{l}2000.5 \\
2442.5 \\
4443.0\end{array}$ & $\begin{array}{l}2062.6 \\
2516.4 \\
4579.0\end{array}$ & $\begin{array}{l}2096.9 \\
2558.2 \\
4655.1\end{array}$ & $\begin{array}{l}2130.4 \\
2599.1 \\
4729.5\end{array}$ & $\begin{array}{l}2146.3 \\
2618.5 \\
4764.8\end{array}$ & $\begin{array}{l}2152.9 \\
2626.5 \\
4779.4\end{array}$ & $\begin{array}{l}2161.3 \\
2636.8 \\
4798.1\end{array}$ \\
\hline
\end{tabular}




\section{DOE PROGRAMS}

\section{Office of Energy Research}

The OER is the largest single sponsor of research at ORNL. Over 40\% of ORNL's operating budget comes from this office. The Laboratory conducts major research programs for OER in the basic physical sciences, fusion energy, and biomedical and environmental sciences areas (see Table 5).

Table 5. OER Major Program summary* $(\$$ in Millions-BA)

\begin{tabular}{llrrr}
\hline B\&R code & \multicolumn{1}{c}{ Major programs } & FY 1983 & FY 1984 & FY 1985 \\
\hline AT & Magnetic Fusion & $76.04^{b}$ & 64.22 & $88.10^{b}$ \\
HAO2 & Biological and Environmental & 25.92 & 28.25 & 31.05 \\
& $\quad$ Research & & & \\
KA & High Energy Physics & 0.64 & 0.62 & $0.99^{b}$ \\
KB & Nuclear Physics & 9.66 & 10.85 & $14.43^{b}$ \\
KC & Basic Energy Sciences & 48.05 & 52.35 & $71.35^{b}$ \\
KD & Energy Research and Analysis & 1.25 & 1.05 & 1.05 \\
KE & University Research Support & 0.19 & 0.19 & 0.23 \\
$\quad$ Total & & 161.75 & 157.53 & $207.20^{b}$ \\
Percent of total & & 45.7 & 39.7 & 44.0 \\
Laboratory funding-BA & & & & \\
\hline
\end{tabular}

${ }^{a}$ Figures include operating BA, capital equipment, and funded/budgeted construction. ${ }^{b}$ Includes forward financing.

\section{AT-Magnetic Fusion}

The Fusion Program at ORNL is a significant component of the U.S. national fusion program, and it encompasses nearly all aspects of magnetic fusion research. The goal of the national fusion program is to determine whether the nuclear energy of the light elements, mainly hydrogen isotopes and lithium, can be released in a useful fashion. The key issues at the current stage of the program are the understanding of the behavior of high-temperature hydrogen isotope plasmas; the development of magnetic configurations that confine plasma effectively and have attractive engineering features; the development of the technologies for producing, heating, and controlling such plasmas; the design of future confinement facilities; and the development of the technologies that will be required for magnetic fusion to move through the engineering phase into the commercial phase.

To accomplish these goals, the major divisions of the ORNL Magnetic Fusion Program are Applied Plasma Physics (AT 05), Confinement Systems (AT 10), and Development and Technology (AT 15).

The Applied Plasma Physics subprogram includes theoretical studies to formulate and apply models of plasma behavior in various confinement systems [tokamak, stellarator, and Elmo Bumpy Torus (EBT)]. This activity also encompasses the development of a data base for atomic physics and the 
development of diagnostic devices and technologies. Substantial advances have been made in all areas. Two new and exciting magnetic configurations have been realized, each of which shows theoretical promise for improved confinement and beta capability. The Advanced Toroidal Facility (ATF) stellarator configuration, which was developed in collaboration with the toroidal experiment group, is the first configuration identified with direct access to the so-called "second" stability regime. A modular version of this device, the "Symmotron," was developed and patented at ORNL. The Elmo Bumpy Square is a variant of the EBT with improved confinement properties. Further studies directed at realizing the full potential of these developments will continue. Significant progress-notably in the areas of excitation-autoionization and low-energy charge exchange-has been achieved in measuring and developing a theoretical base for important atomic cross sections. For the future program, an improved source of multiply charged ions is being constructed.

The Confinement Systems activities include experimental and design studies in both the toroidal and EBT plasma configurations. In the toroidal studies, the investigation of beta limitations with the ISX-B tokamak will continue through mid-FY 1984. The main new features of this program are (1) the addition of a new neutral beam system to allow co-plus counter injection, (2) improved diagnostics to measure the toroidal rotation speed, which can now be varied, and (3) a diagnostic heavy-ion beam for radial potential measurements-a collaborative program with Rensselaer Polytechnic Institute (RPI). In early FY 1985, the Impurity Study Experiment (ISX-B) will be dismantled in preparation for the installation of the ATF torsatron. During the period mid-FY 1984 through early FY 1986, the main part of the toroidal experimental team will move to Princeton Plasma Physics Laboratory (PPPL), where ORNL's researchers will play a major role in the Tokamak Fusion Test Reactor (TFTR) tokamak program. Key personnel in the expanding stellarator program will remain to work on the ATF project with Union Carbide CorporationNuclear Division (UCC-ND) engineering. The ATF experimental program will start in early FY 1987. The ATF is a flexible machine designed to make major contributions to the improvement of the toroidal confinement concept in the areas of high beta and steady-state operation.

Several new EBT-like configurations have been developed which offer the promise of substantially improved confinement. In parallel, recent experiments on EBT-Scale (EBT-S) indicate that while the confinement scaling is consistent with neoclassical models, the magnitude of confinement is less than previous estimates. Together with overall fusion budget constraints these factors have led to a postponement of EBT-P construction. To compensate for this action, the next year will be devoted to an increased emphasis on the EBT-S experiments and an extensive study in collaboration with the national EBT community to identify an improved configuration for a subsequent experiment.

The ORNL Development and Technology Program continues to make progress on all fronts. In the neutral-beam area, the program is close to successfully completing a prototype source for the Mirror Fusion Test Facility (MFTF-B) mirror machine at Lawrence Livermore National Laboratory (LLNL). Current DOE plans call for termination of the beam activity in FY 1984. The ORNL Plasma Technology section-following its selection by the DOE Office of Fusion Energy to lead this activity-will then turn its attention to the development of radio frequency (rf) systems. An of test facility, which is based upon the prototype superconducting EBT-P coils, has been approved and will be in operation in 1985. The pellet-injector program has developed both pneumatic and mechanical injectors capable of repetitively providing pellets at speeds of about 1 $\mathrm{km} / \mathrm{s}$. These injectors are in use at the Massachusetts Institute of Technology (MIT), ORNL, and 
PPPL. The next phase of the program will concentrate on higher velocity pellets and will develop a tritium pellet injector for TFTR.

The Large Coil Test Facility (LCTF) is ready to begin the two-coil test of the large-coil program undertaken through the International Energy Agency. The six superconducting coils of various designs each have an inner bore of $2.5 \mathrm{~m}$ by $3.5 \mathrm{~m}$ and will generate an 8-T magnetic field in a toroidal array. The two-coil test will ulitize the Japanese coil, which was built by Hitachi, and the first U.S. coil, from General Dynamics. The final decision on the extent of work which should be undertaken to complete the General Electric coil will be made shortly. It is hoped that all six coils, including those from Westinghouse, Siemens (European Economic Community), and Brown-Boveri (Switzerland) should be delivered on installed during FY 1984. Also in the superconducting area, prototype EBT-proof-of-principle coils were developed successfully with General Dynamics-Convair Division.

The plasma materials program has been successful in demonstrating control of plasma density by a pumped limiter in ISX-B-a procedure developed in a collaboration with Sandia National Laboratory (SNL). In the radiation materials area, work continues in the High Flux Isotope Reactor (HFIR) and the Oak Ridge Research Reactor (ORR) to test candidate first-wall and blanket materials. An agreement has been made with the Japanese Atomic Energy Research Institute (JAERI) to test materials for the Japanese program. A collaboration with Argonne National Laboratory (ANL) is under way to test tritium production in a lithium-aluminate blanket. In the neutronics area, work continues in assembling computer codes and in calibrating the codes against model experiments with a 14-M(e)V neutron source. A collaborative program for neutronics on TFTR is under way with PPPL. The technical basis document for an Environmental Impact Statement will also be issued shortly. Further work will continue on finalizing a Generic Environmental Impact Statement for fusion.

The Fusion Engineering Design Center (FEDC), which is hosted by ORNL, involves a major collaboration with a number of U.S. industries, national laboratories, and universities. The FEDC developed the engineering design for the Fusion Engineering Device and for the U.S. contribution to the International Atomic Energy Agency-International Tokamak Reactor (IAEA-INTOR) activity. During the past year, the program has expanded. The design center continues to collaborate with PPPL in the engineering of the next phases of the toroidal program. In addition, in collaboration with LLNL, approximately $50 \%$ of its effort is now devoted to the engineering of the next phase of the tandem mirror program. This work is expected to continue for a number of years, and it may well be extended to include supporting studies for other concepts.

AT-Magnetic Fusion Program resource summary

\begin{tabular}{|c|c|c|c|c|c|c|c|c|c|c|c|c|c|c|c|c|}
\hline \multirow{2}{*}{$\begin{array}{c}(\$ \text { in Millions })^{a} \\
(\text { Personnel in FTEs) }\end{array}$} & \multicolumn{2}{|c|}{ FY 1982} & \multicolumn{2}{|c|}{ FY 1983} & \multicolumn{2}{|c|}{ FY 1984} & \multicolumn{2}{|c|}{ FY 1985} & \multicolumn{2}{|c|}{ FY 1986} & \multicolumn{2}{|c|}{ FY 1987} & \multicolumn{2}{|c|}{ FY 1988} & \multicolumn{2}{|c|}{ FY 1989} \\
\hline & $\mathbf{B A}$ & $\mathbf{B O}$ & BA & BO & BA & BO & BA & BO & $\mathbf{B A}$ & BO & $\mathrm{BA}$ & BO & $\mathbf{B A}$ & BO & BA & BO \\
\hline Total Operating & 55.8 & 55.3 & $67.9^{b}$ & 58.5 & 59.0 & 63.5 & $80.1^{b}$ & 68.2 & 68.2 & 68.2 & 68.2 & 68.2 & 68.2 & 68.2 & 68.2 & 68.2 \\
\hline Capital Equipment & 9.5 & & 8.1 & & 5.2 & & 8.0 & & 6.7 & & 6.7 & & 6.7 & & 6.7 & \\
\hline Construction & 19.4 & & 0.0 & & 0.0 & & 0.0 & & 0.0 & & 0.0 & & 0.0 & & 0.0 & \\
\hline $\begin{array}{l}\text { Total for major } \\
\text { programs }\end{array}$ & 84.7 & 55.3 & 76.0 & 58.5 & 64.2 & 63.5 & 88.1 & 68.2 & 74.9 & 68.2 & 74.9 & 68.2 & 74.9 & 68.2 & 74.9 & 68.2 \\
\hline Direct Personnel & 176.5 & & 187.0 & & 175.0 & & 175.0 & & 175.0 & & 175.0 & & 175.0 & & 175.0 & \\
\hline
\end{tabular}

${ }^{a}$ An $8.5 \%$ inflation factor has been used between FY 1983 and FY 1984 and between FY 1984 and FY 1985. FY 1986-FY 1989 amounts are in constant FY 1985 dollars.

${ }^{6}$ Includes approximately $\$ 13 \mathrm{M}$ in forward financing for FY 1984. 


\section{HAO2-Biological and Environmental Research}

OER's Office of Health and Environmental Research (OHER) continues to provide the largest portion of funding (56\%) for the biomedical and environmental sciences program at ORNL. During the past several years, many program elements have been lost, and the size of the staff has been reduced significantly due to reduced budgets and less than cost-of-living increases in many areas. However, we believe that this trend has leveled out. Beginning in FY 1984, the HAO2 (Environmental Research and Development) and HB (Life Sciences Research and Nuclear Medicine Applications) programs will be consolidated under the single activity code HAO2 (Biological and Environmental Research).

The goals of the HAO2 program are to study the interaction of energy-related physical and chemical agents with living organisms, including their transport, chemical evolution, adverse health effects, and ultimate fate in man and his environment; to develop knowledge through basic research programs; and to transfer research findings and technological developments outside the Laboratory. Areas of research include radiation biology, radiation and chemical dosimetry, carcinogenesis, mutagensis, genetics, epidemiology, health and environmental risk analysis, physical and chemical characterization of pollutants and their interactions at the molecular level, development of advanced instrumentation for sensitive detection and monitoring of chemical species, carbon dioxide effects research and assessment, and nuclear medicine. In addition, two unique research resources are supported by the HAO2 budget: the Health Physics Research Reactor (HPRR) and the Oak Ridge National Environmental Research Park (NERP). We are also currently developing plans for a biotechnology user facility at ORNL which would integrate resources in the Biology and Chemical Technology divisions. Physical resources would include bioreactors, a flow cytometry laboratory, large-volume fermenters, and centrifugal analyzers. Users of all of these facilities include staff of industry and national laboratories and students and staff of universities.

The ORNL HAO2 program is among the largest life sciences research programs in the country. It covers a broad range of both basic and applied studies. The work is carried out primarily by the staff of four divisions and one program: the Biology, Environmental Sciences, Health and Safety Research, and Information divisions and the Life Sciences Synthetic Fuels Program (LSSFP), with additional assistance from numerous other ORNL divisions. Overall, the HAO2 program at ORNL is expected to experience little or no real growth in this planning cycle, although some subprogram elements are proposing modest expansion. The most significant change currently projected concerning the research carried out in the Biology Division is a redirection of our biophysics efforts to concentrate on the study of genetic materials, including dioxyribonucleic acid (DNA) adduct formation with energy-related chemicals. We are using electron microscope tomography and smallangle scattering (neutron and $x$-ray) to study macromolecular structure. We think that it is important to maintain a biophysics program that could be built back up as new funds become available. We also anticipate increases in neutron radiobiology.

Environmental research is designed to increase the ability to predict transport and effects of energy-related contaminants in the environment. Basic knowledge is obtained on mechanisms that control and influence total ecosystems, on their resiliency, and on the critical elements within them. Through utilization of model compounds, radionuclides, and mathematical models, data and techniques are developed which will enhance the ability to site and operate energy systems in a 
cost-effective and environmentally safe manner. We will continue to expand our expertise in hydrology and geochemistry in support of the developing DOE programs in hazardous waste disposal.

Assessments of potential health and environmental risks associated with new and existing energy technologies require knowledge of the interaction of potentially hazardous agents with biological and environmental systems and the technical capability for characterizing and quantitatively measuring such agents in various settings. The physical and technological components of the program consist of studies involving the structure and properties of materials of biological or environmental importance, the physical mechanisms that govern transport and chemical evolution of pollutants in the atmosphere, and the interaction of harmful agents with biological materials. The scope of work includes unique applications of laser optical techniques to atomic and molecular physics studies and solid-state and surface physics studies, and the development of advanced instrumentation for characterizing and sensitively detecting a wide variety of chemical species.

In addition to studying the properties of energy-related compounds and how the agents move in the environment and might affect ecosystems, we conduct experimental work to contribute to our understanding of potential health risks to man and other organisms. We use a range of test agents: ultraviolet and ionizing radiation, and numerous chemical pollutants and toxic compounds, including atmospheric halogenated hydrocarbons and compounds produced from the use and conversion of fossil fuels. The study systems employed include bacteria, viruses, fruit flies, mice, and many types of human and animal cells in culture.

The Nuclear Medicine Program involves the design and preclinical testing of new radiopharmaceuticals for use in clinical nuclear medicine and other radiolabeled agents for fundamental biomedical research. A new gamma camera is being installed to provide imaging capability. Current research focuses on the development of radiolabeled fatty acids, phosphonium, and related cations for the evaluation of heart disease and on the perfection of a generator for the production of radioactive iridium from osmium-191. The iridium-191m radionuclide has a short half-life $(5 \mathrm{~s})$ and is an effective agent for evaluating congenital heart disease in children, allowing rapid repeat studies with very low radiation doses absorbed by the patient. A key strength of this program is the strong synthesizing capability; a variety of new, improved radiolabeling techniques are also being developed. An important outreach is the vigorous medical cooperative program with prestigious clinical research groups, such as the Massachusetts General Hospital, to which these new agents are supplied.

The activities of the LSSFP will continue to shift away from site- or technology-specific studies toward more basic, generic research involving a change in program emphasis-if adequate support is available-from short-term acute exposures to long-term chronic exposures. We will, however, continue to monitor specific synthetic fuel industry plants to ensure transfer of relevant information and techniques to prospective users. The erosion of support and the uncertainty in national energy priorities are impediments to LSSFP program planning. However, OHER planning, in which ORNL has had a major role, should help clarify directions for the LSSFP. Emphasis will likely be placed on the genetic and toxicological effects produced by complex mixtures and pure compounds identified within these mixtures.

During the next five years, the global carbon cycling program activities will undergo a significant expansion to encompass new research in terrestrial carbon dynamics and global carbon cycle 
modeling, as well as new responsibilities in carbon cycle research management for DOE. Research efforts will be focused on assembling and implementing disaggregated (multidimensional) models of the global carbon cycle. Management activities will involve the gradual assimilation of a greater share of contract execution activities for the DOE Carbon Cycle Researcch Program, particularly in the areas of oceanic and atmospheric data collection and analysis. This broad array of activities and expertise is necessary to develop the information and models necessary to provide accurate projections of $\mathrm{CO}_{2}$ buildup in the atmosphere over the next century from both natural and anthropogenic sources.

The Carbon Dioxide Information Center, one of 17 specialized information centers at ORNL, supports the nation's Carbon Dioxide and Climate Research Program by providing a focal point for compilation and distribution of $\mathrm{CO}_{2}$-related information under systematic quality control. The prototype center, which was established in FY 1982 and FY 1983, is intended to expand to a fully operational information analysis center in the near future. Expansion is necessary to allow incorporation of data from more research areas and to achieve international-rather than only national-coverage of $\mathrm{CO}_{2}$ research.

HAO2-Biological and Environmental Research Program resource summary

\begin{tabular}{|c|c|c|c|c|c|c|c|c|c|c|c|c|c|c|c|c|}
\hline \multirow{2}{*}{$\begin{array}{c}\text { ( } \$ \text { in Millions })^{a} \\
\text { (Personnel in FTEs) }\end{array}$} & \multicolumn{2}{|c|}{ FY 1982} & \multicolumn{2}{|c|}{ FY 1983} & \multicolumn{2}{|c|}{ FY 1984} & \multicolumn{2}{|c|}{ FY 1985} & \multicolumn{2}{|c|}{ FY 1986} & \multicolumn{2}{|c|}{ FY 1987} & \multicolumn{2}{|c|}{ FY 1988} & \multicolumn{2}{|c|}{ FY 1989} \\
\hline & BA & BO & BA & BO & $\mathbf{B A}$ & BO & BA & BO & BA & BO & BA & BO & BA & BO & BA & BO \\
\hline Total Operating & 27.9 & 27.9 & 24.1 & 27.0 & 26.8 & 29.3 & 29.5 & 29.5 & 29.5 & 29.5 & 29.5 & 29.5 & 29.5 & 29.5 & 29.5 & 29.5 \\
\hline Capital Equipment & 1.9 & & 1.8 & & 1.5 & & 1.6 & & 1.6 & & 1.6 & & 1.6 & & 1.6 & \\
\hline Construction $^{b}$ & 1.0 & & 0.0 & & 0.0 & & 0.0 & & 0.0 & & 0.0 & & 0.0 & & 0.0 & \\
\hline $\begin{array}{l}\text { Total for major } \\
\text { programs }\end{array}$ & 30.8 & 27.9 & 25.9 & 27.0 & 28.3 & 29.3 & 31.1 & 29.5 & 31.1 & 29.5 & 31.1 & 29.5 & 31.1 & 29.5 & 31.1 & 29.5 \\
\hline Direct Personnel & 227.1 & & 198.0 & & 200.0 & & 200.0 & & 200.0 & & 200.0 & & 200.0 & & 200.0 & \\
\hline
\end{tabular}

\footnotetext{
${ }^{\circ}$ An $8.5 \%$ inflation factor has been used between FY 1983 and FY 1984 and between FY 1984 and FY 1985. FY 1986-FY 1989 amounts are in constant FY 1985 dollars.

${ }^{b}$ Does not include proposed construction.
}

Program Construction. ORNL is proposing five line-item construction projects for the HA02 program.

HAO2-Proposed construction summary

\begin{tabular}{|c|c|c|c|c|c|c|c|c|}
\hline ( $\$$ in Millions) & FY 1983 & FY 1984 & FY 1985 & FY 1986 & FY 1987 & FY 1988 & FY 1989 & TEC \\
\hline $\begin{array}{l}\text { Hazardous Waste } \\
\text { Incinerator }\end{array}$ & & 1.8 & & & & & & 1.8 \\
\hline $\begin{array}{l}\text { Health and Safety } \\
\text { Research Laboratory }\end{array}$ & & & 3.0 & & & & & 3.0 \\
\hline $\begin{array}{l}\text { Upgrade Air } \\
\text { Supply System }\end{array}$ & & & 3.0 & & & & & 3.0 \\
\hline $\begin{array}{l}\text { Toxic Substances } \\
\text { Laboratory and } \\
\text { Animal Facility }\end{array}$ & & & & 5.8 & 28.2 & 1.5 & & 35.5 \\
\hline $\begin{array}{c}\text { Upgrade Air Supply } \\
\text { System, Genetics } \\
\text { Facility, Phase II }\end{array}$ & & & & 3.0 & & & & 3.0 \\
\hline
\end{tabular}


The largest item, the Toxic Substances Laboratory and Animal Facility, is a new facility for handling toxic materials. The purpose of the project is to provide specialized laboratories and space for animals to be used in investigating acute and chronic effects of energy-related toxic chemicals and metals. The development and maintenance by DOE of a program to study toxic effects of such materials are essential to future protection of energy industry workers, the general public, and the environment. DOE's recently established toxicology program requires that we have new laboratory and animal space designed specifically to enable personnel to handle toxic materials safely. This proposed construction is also consistent with the Laboratory's long-range goal to consolidate to the maximum extent the life sciences research facilities at the west end of the ORNL (X-10) site. Further discussion of the intention to move the Biology Division from Y-12 to ORNL is included in the Site Development and Facilities Management section of this plan.

\section{KA, KB, KC-Basic Physical Sciences}

Nine ORNL divisions conduct basic research that is supported by the OER. Activities include nuclear and high-energy physics and a broad spectrum of research in the nuclear, chemical, materials, engineering, and mathematical sciences and geosciences. The eight national user facilities for basic physical science research at ORNL hosted over 350 outside researchers during FY 1983.

\section{KA-High Energy Physics}

The High Energy Physics group maintains experimental programs at several accelerator facilities. In addition, the group provides an essential service to the physics community by measuring and calculating multigroup cross sections and transport phenomena for a wide variety of applications. Nuclear cross-section models and nucleon-meson transport methods are developed that facilitate the design of high-energy particle detection systems such as ionization calorimeters and total absorption calorimeters. Design data as well as detailed designs are provided to outside experimental groups engaged in detector construction. A parallel effort provides the information required for meeting radiation shielding requirements.

KA-High Energy Physics Program resource summary

\begin{tabular}{|c|c|c|c|c|c|c|c|c|c|c|c|c|c|c|c|c|}
\hline \multirow{2}{*}{$\begin{array}{c}(S \text { in Millions) } \\
(\text { Personnel in FTEs) }\end{array}$} & \multicolumn{2}{|c|}{ FY 1982} & \multicolumn{2}{|c|}{ FY 1983} & \multicolumn{2}{|c|}{ FY 1984} & \multicolumn{2}{|c|}{ FY 1985} & \multicolumn{2}{|c|}{ FY 1986} & \multicolumn{2}{|c|}{ FY 1987} & \multicolumn{2}{|c|}{ FY 1988} & \multicolumn{2}{|c|}{ FY 1989} \\
\hline & BA & BO & $\mathbf{B A}$ & BO & BA & BO & $\mathbf{B A}^{b}$ & BO & BA & BO & BA & BO & BA & $\mathrm{BO}$ & BA & BO \\
\hline Total Operating & 0.55 & 0.62 & 0.6 & 0.6 & 0.6 & 0.6 & 0.9 & 0.7 & 0.7 & 0.7 & 0.7 & 0.7 & 0.7 & 0.7 & 0.7 & 0.7 \\
\hline Capital Equipment & 0.05 & & 0.05 & & 0.03 & & 0.13 & & 0.13 & & 0.13 & & 0.13 & & 0.13 & \\
\hline Construction & 0.0 & & 0.0 & & 0.0 & & 0.0 & & 0.0 & & 0.0 & & 0.0 & & 0.0 & \\
\hline $\begin{array}{c}\text { Total for major } \\
\text { programs }\end{array}$ & 0.60 & 0.62 & 0.7 & 0.6 & 0.6 & 0.6 & 1.0 & 0.7 & 0.8 & 0.7 & 0.8 & 0.7 & 0.8 & 0.7 & 0.8 & 0.7 \\
\hline Direct Personnel & 5.0 & & 4.5 & & 5.3 & & 5.3 & & 5.3 & & 5.3 & & 5.3 & & 5.3 & \\
\hline
\end{tabular}

${ }^{a}$ An $8.5 \%$ inflation factor has been used between FY 1983 and FY 1984 and between FY 1984 and FY 1985. FY 1986-FY 1989 amounts are in constant FY 1985 dollars.

${ }^{b}$ Includes approximately $\$ 0.2 \mathrm{M}$ in forward financing for FY 1986. 


\section{KB-Nuclear Physics}

The principal activities in the Nuclear Physics Program are centered on the Holifield Heavy Ion Research Facility (HHIRF). The HHIRF is operated as a unique resource for heavy-ion research for the national and international user communities, and it forms the basis of a vigorous in-house nuclear physics research program.

The resources available to users of the HHIRF continue to grow. Laboratory space has been augmented significantly by the completion of a $3500-\mathrm{ft}^{2}$ addition to the experimental halls, constructed under FY 1983 General Plant Projects (GPP) auspices. An additional 2400- $\mathrm{ft}^{2}$ extension is planned as an FY 1984 GPP project to accommodate heavy-ion applications and accelerator-based atomic physics experiments. Construction funded by the State of Tennessee has begun on a $6000-\mathrm{ft}^{2}$ building that will house laboratories, offices, and a conference facility. Combined with the continued development in the KB program of state-of-the-art detectors, data acquisition electronics, computing facilities, and additional accelerated ion-species, these projects have greatly enhanced the capabilities of the HHIRF. A major effort is currently under way to bring the Holifield tandem accelerator to full operating voltage.

Experiments with the spin spectrometer in the past year revealed for the first time evidence for shape changes in highly excited nuclei at very high angular momentum. In another significant accomplishment, time scales for heavy-ion reactions were measured using the phenomenon of channeling in diamond crystals.

A near-term goal for facility improvement is to provide ion beams spanning the periodic table at energies exceeding the uranium Coulomb barrier-5 MeV/nucleon--by converting the Oak Ridge Isochronous Cyclotron (ORIC) coils to superconducting windings.

As a longer range thrust, we are developing concepts for a relativistic heavy-ion accelerator capable of producing the high-energy densities required to form a quark-gluon plasma in nuclear matter. While the ultimate goal of the project would thus be to study quark deconfinement, the facility would provide for forefront research in a variety of fields.

KB-Nuclear Physics Program resource summary

\begin{tabular}{|c|c|c|c|c|c|c|c|c|c|c|c|c|c|c|c|c|}
\hline \multirow{2}{*}{$\begin{array}{c}\text { ( } \$ \text { in Millions) } \\
\text { (Personnel in FTEs) }\end{array}$} & \multicolumn{2}{|c|}{ FY 1982} & \multicolumn{2}{|c|}{ FY 1983} & \multicolumn{2}{|c|}{ FY 1984} & \multicolumn{2}{|c|}{ FY 1985} & \multicolumn{2}{|c|}{ FY 1986} & \multicolumn{2}{|c|}{ FY 1987} & \multicolumn{2}{|c|}{ FY 1988} & \multicolumn{2}{|c|}{ FY 1989} \\
\hline & BA & $\mathrm{BO}$ & BA & BO & BA & BO & $\mathbf{B A}^{b}$ & BO & BA & BO & BA & BO & BA & BO & BA & $\mathrm{BO}$ \\
\hline Total Ope & 8.7 & 8.9 & 8.7 & 9.0 & 9.6 & 9.6 & 13.1 & 11.0 & 11.4 & 11.3 & 11.7 & 11.6 & 12.0 & 11.9 & 12.4 & 12.3 \\
\hline Capital Equipment & 1.0 & & 1.0 & & 1.3 & & 1.4 & & 1.4 & & 1.4 & & 1.5 & & 1.5 & \\
\hline Construction ${ }^{c}$ & 0.5 & & 0.0 & & 0.0 & & 0.0 & & 0.0 & & 0.0 & & 0.0 & & 0.0 & \\
\hline $\begin{array}{l}\text { Total for major } \\
\text { programs }\end{array}$ & 10.2 & 8.9 & 9.7 & 9.0 & 10.9 & 9.6 & 14.5 & 11.0 & 12.8 & 11.3 & 13.1 & 11.6 & 13.5 & 11.9 & 13.9 & 12.3 \\
\hline Direct Personnel & 91.0 & & 73.8 & & 79.3 & & 82.3 & & 85.6 & & 88.9 & & 92.1 & & 96.0 & \\
\hline
\end{tabular}

${ }^{\circ}$ An $8.5 \%$ inflation factor has been used between FY 1983 and FY 1984 and between FY 1984 and FY 1985. FY 1986-FY 1989 amounts are in constant FY 1985 dollars.

${ }^{b}$ Includes approximately $\$ 2.1 \mathrm{M}$ in forward financing for FY 1986.

'Does not include proposed construction. 
Program Construction. An Accelerator Improvement and Modification (AIM) project is proposed for HHIRF as follows:

KB-Proposed construction summary

\begin{tabular}{lcccccccc}
\hline (\$ in Millions) & FY 1983 & FY 1984 & FY 1985 & FY 1986 & FY 1987 & FY 1988 & FY 1989 & TEC \\
\hline AIM-HHIRF & & & & 0.5 & & & & 0.5 \\
Total proposed & & & & 0.5 & & & & 0.5 \\
construction & & & & & & & & \\
\hline
\end{tabular}

\section{KC-Basic Energy Sciences (BES)}

Major components of work in the nuclear sciences are the production, separation, and study of actinide elements; the measurement of neutron cross sections relevant to fusion and fission reactor development; and the preparation of special isotopes.

Several important scientific questions are being addressed in research with transuranium elements and compounds. The possible involvement of the $5 f$ electrons (of the actinide series) in chemical bonding has been investigated in magnetic studies of the metals and compounds of americium through einsteinium at low temperatures, and in structural studies of berkelium and californium metals at high pressures. The results so obtained indicate weaknesses in present-day theories of actinides in the solid state. Investigations of actinides in solution are focusing on hydration, hydrolysis, complexation phenomena, and searches for unusual oxidation states in order to establish the limits of chemical stability of these elements. Chemical behavior under conditions that are relevant to nuclear waste isolation is being emphasized with regard to chemical speciation in the environment and to preparation of potential alternate crystalline waste forms. Measurements of neutron cross sections have indicated that an approximate tenfold increase in the production of 276-d ${ }^{254}$ Es is possible at the ORNL HFIR. Multimicrogram amounts of ${ }^{254} \mathrm{Es}$ are needed for accelerator targets in new superheavy-element searches and in chemical studies of elements 101 through 106. Other new research areas that are being developed include high-temperature thermodynamic and kinetic studies with a dedicated mass spectrometer with Knudsen effusion cell; neutron scattering of solutions at HFIR; and scattering of variable-energy $\mathrm{X}$ rays from solutions at the National Synchrotron Light Source (NSLS).

Although the Oak Ridge Electron Linear Accelerator (ORELA) has been the world's leading facility for time-of-flight measurements using intermediate-energy (keV) neutrons, improvements in two European facilities are bringing them close to parity with ORELA. A study is now under way that examines the many recent advances in accelerator development to determine whether major increases in the pulsed-neutron source strength can be achieved at reasonable cost. The interim finding is that tenfold to hundredfold advances would be quite expensive but might meet multiple objectives. Cost-effective but relatively minor improvements in ORELA facilities are being sought currently.

Stable isotope production continues to be a highly important nuclear science program. Efforts continue to develop funding mechanisms that can accommodate fluctuations in sales and ensure replenishment of inventories. 
Materials science is the largest BES program and is shared among the Solid State, Metals and Ceramics, Chemical Technology, and Chemistry divisions. This program, which is guided by the needs of the DOE missions, deals with fundamental studies of mechanical, physical, chemical, optical, electrical, and magnetic properties of materials.

Important basic experimental research is performed on diverse problems having to do with energyrelated materials, such as radiation effects in fission and fusion reactor materials, photovoltaic conversion in solar cells, storage of nuclear wastes in minerals, fast-ion conduction in solid electrolytes for batteries and fuel cells, and flux-line pinning effects in type II superconductors for magnets. Closely coupled to the experimental work are theoretical studies that involve state-of-theart investigations, including relevant extensions of existing theories as well as the development of new concepts, theories, and procedures, when appropriate. The theoretical research falls very generally under the classifications of electronic and magnetic properties, lattice dynamics, surface physics, particle-solid interactions, laser annealing, and theory of alloys.

Materials preparation and characterization are major components of the program. Ceramic processing emphasizes designing materials for use at elevated temperatures and developing an understanding of mechanical properties at elevated temperatures. Metallic alloys based on $\mathrm{Ni}_{3} \mathrm{Al}$ are being prepared, and their properties are being controlled by thermal-mechanical processing as well as by microalloying. Titanium diboride is being prepared by homogeneous nucleation from gaseous phases, and various techniques are being used to improve the mechanical, high-temperature properties of this ceramic.

Ion-implantation doping and pulsed-laser annealing are being used to modify the surface properties of many types of materials. These surface modifications significantly affect such phenomena as friction, wear, corrosion, catalysis, and superconductivity, as well as the electronic properties of semiconductors. Recent studies of ion-implanted ceramic materials have demonstrated that the mechanical properties of ceramic surfaces can be controlled by selective implantations and thermal annealing. The continuing development of laser-annealing techniques has resulted in routine laboratory production of very high efficiency, single-crystal silicon solar cells. The strong interest in the alteration and analysis of surfaces of materials by both in-house and outside users has resulted in a flourishing national user facility for surface modification and characterization research.

Several large, unique facilities are available at ORNL for research in the materials sciences. Included among them are (1) a variety of neutron-scattering facilities at the HFIR, which furnishes the most intense beams of thermal neutrons now available for research; (2) facilities at the Bulk Shielding Reactor for closely controlled investigations of radiation effects at very low temperatures; (3) several accelerators for research in ion-radiation damage, ion implantation, ion scattering, and ion channeling; (4) high-voltage and high-resolution electron microscopes; and (5) a unique 10-m, small-angle, X-ray-scattering camera. User groups have been formed for many of these facilities so that they will be readily accessible to scientists both within and outside ORNL. Architectural engineering work is beginning on the new High Temperature Materials Laboratory (HTML). Completion of the building to house HTML is anticipated for the second quarter of FY 1987. HTML will be a state-of-the-art facility for materials science research and will be available to Laboratory, industry, and university scientists.

Synchrotron radiation is rapidly becoming a major tool for materials science research. For example, fundamental studies of melting processes and other transient phenomena are made possible by 
diffraction measurements with synchrotron $X$ rays. ORNL has built equipment to be installed at the NSLS. The NSLS will have a flexible $X$-ray-scattering facility with a very efficient focusing device and a multipurpose facility on the vacuum uv ring for surface studies.

Chemical sciences work is conducted in four ORNL divisions. Analytical research in the Analytical Chemistry Division currently emphasizes microwave, positron, optoacoustic, and mass spectroscopic measurements. Laser-based techniques are prominent.

In the Chemistry Division there are diverse activities. A unique combination of techniques is used to obtain basic thermodynamic and kinetic data on aqueous solutions under the high pressures and temperatures common to energy-production facilities. Recent work has shown that heats of dilution can be enormous in some electrolyte solutions at high temperatures and has given evidence for ion association. These results are important for the theoretical understanding of water and its solutions, and they also provide a basis for detailed descriptions for systems important to steam generation, nuclear coolants, geochemical and hydrothermal processes, waste transport, nuclear accident assessment, and supercritical fluid processing. Results of studies of the high-temperature chemistry of sodium sulfate provide a basis for evaluation of its precipitation behavior within steam generator crevices and its potential for enhancing corrosion. Hydrolysis studies have advanced the understanding of iodine solution chemistry relevant to reactor accident conditions.

Basic research on coal attempts to ensure that this resource is used to best advantage. A combination of instrumental and chemical techniques is used to elucidate the structures of the organic molecules in coal and their functional groups and reactions. Work with model compounds is an integral part of the approach because native coals are too complicated to understand otherwise. Recent results have included the development of ultrahigh-resolution nuclear magnetic resonance techniques for studying functional groups and carbon structures in native, chemically modified, and thermally altered coals; the use of electron spin resonance to study free radical processes in pyrolyzing hydrocarbons; and the elucidation of molten salt catalytic mechanisms in hydrogen shuffling and condensation reactions of model compounds for coal.

Basic research on the chemistry of solvent extraction is being conducted for the separation of metals. Emphasis is on the principles controlling the selectivity of extractants on the molecular level and application of these principles in devising new and more selective extractants. Recent work has provided structural information on species related to the extracted complex in the diethylhexyl phosphoric acid-trioctyl phosphine oxide (DEPA-TOPO) process for uranium extraction from phosphoric acid.

In a program of far-reaching significance, electron spectroscopy at synchrotron sources is now providing the best and most comprehensive basis for evaluating molecular orbital theory and photoelectron dynamics. Experiments on core as well as valence orbitals hold a promise for a new approach to the study of chemical bonding. Recently, studies have been completed on diverse gaseous systems including metallic vapors such as gallium and on relatively complicated multiatom organic molecules such as dichloroethylene nitrous oxide.

The BES programs in the Chemical Technology Division involve chemical and engineering research in separations science and technology, energy production, and conservation. Fuel cycle chemistry is an important component of the separations program and is essential to closing the fuel cycle. Research on the biophotolysis of water is another important and promising area receiving emphasis. 
The BES Division of Engineering, Mathematical, and Geosciences supports a variety of programs at ORNL. The Geosciences Program addresses the broad areas of hydrothermal and silicate fluids, which promote transportation and redistribution of materials in the earth's crust. A new facility enables the study of oxidation and reduction processes in geologic materials under conditions simulating depths to $18 \mathrm{~km}$. The main component of the facility is an internally heated pressure vessel capable of operating at hydrogen pressures up to $500 \mathrm{MPa}$ and temperatures to $1400^{\circ} \mathrm{C}$. Also, in a program on hydrothermal mobility, the first experimental study on the behavior of tungsten in solution at high temperatures was completed at ORNL. The results provide the basis for a comprehensive model for the mobility and deposition of tungsten over a wide range of conditions.

The principal objective of our mathematics research is to develop methodology and tools applicable to the solution of currently intractable problems in computational linear algebra, moving boundary problems, stochastic analysis, and statistical methods. Emphasis is placed on the design and analysis of algorithms for large-scale sparse matrix computations and for the design of critical experiments. The computer remains a central element in the research program, and a Research Computing Facility based on a VAX 11/780 has been established to provide an experimental laboratory for testing new algorithms on simulated future computer architectures.

The Center for Engineering Systems Advanced Research (CESAR) is a program initiative within the BES. CESAR is a center of multidisciplinary research within which advances in mathematics and mechanical, electrical, and computing systems are integrated for the long-range development of energy-related intelligent control systems. Potential applications include emergency situations, remote operations, resource exploration, transportation systems, and large-scale power generation systems.

\begin{tabular}{|c|c|c|c|c|c|c|c|c|c|c|c|c|c|c|c|c|}
\hline & & & & & $C-B E S$ & Prog & ram res & urce $s$ & ummary & & & & & & & \\
\hline \multirow{2}{*}{$\begin{array}{c}(\$ \text { in Millions) } \\
\text { (Personnel in FTEs) }^{a, b}\end{array}$} & \multicolumn{2}{|c|}{ FY 1982} & \multicolumn{2}{|c|}{ FY 1983} & \multicolumn{2}{|c|}{ FY 1984} & \multicolumn{2}{|c|}{ FY 1985} & \multicolumn{2}{|c|}{ FY 1986} & \multicolumn{2}{|c|}{ FY 1987} & \multicolumn{2}{|c|}{ FY 1988} & \multicolumn{2}{|c|}{ FY 1989} \\
\hline & BA & $\mathrm{BO}$ & BA & BO & BA & $\mathrm{BO}$ & $\mathbf{B A}^{b}$ & BO & BA & $\mathrm{BO}$ & BA & BO & BA & BO & BA & BO \\
\hline Total Operating & 40.3 & 41.5 & 44.6 & 45.2 & 47.3 & 47.4 & 65.9 & 54.9 & 57.2 & 56.7 & 58.2 & 57.9 & 59.2 & 58.9 & 60.1 & 59.8 \\
\hline Capital Equipment & 3.5 & & 3.4 & & 4.4 & & 5.5 & & 5.1 & & 5.0 & & 5.0 & & 5.0 & \\
\hline Construction ${ }^{c}$ & 0.0 & & 0.0 & & 0.6 & & 0.0 & & 0.0 & & 0.0 & & 0.0 & & 0.0 & \\
\hline $\begin{array}{c}\text { Total for major } \\
\text { programs }\end{array}$ & 43.8 & 41.5 & 48.0 & 45.2 & 52.3 & 47.4 & 71.4 & 54.9 & 62.3 & 56.7 & 63.2 & 57.9 & 64.2 & 58.9 & 65.1 & 59.8 \\
\hline Direct Personnel & 376.6 & & 393.5 & & 399.1 & & 414.1 & & 426.0 & & 435.5 & & 443.5 & & 450.5 & \\
\hline
\end{tabular}

Program Construction. Two AIM projects are budgeted for the KC program as follows:

KC-Budgeted construction summary

\begin{tabular}{lcccccccc}
\hline ( ( in Millions) & FY 1983 & FY 1984 & FY 1985 & FY 1986 & FY 1987 & FY 1988 & FY 1989 & TEC \\
\hline AIM-Calutron & & 0.3 & & & & & & 0.3 \\
AIM-ENTANDEM & 0.3 & & & & & & 0.3 \\
Total budgeted & & 0.6 & & & & & & 0.6 \\
construction & & & & & & & & \\
\hline
\end{tabular}


In addition, four items are proposed for construction under KC: an AIM project to upgrade the ORELA; a new Analytical Mass Spectrometry Laboratory (AMSL); and two Accelerator and Reactor Improvements and Modifications Projects (ARIM) for upgrading HFIR-an ARIM-HFIR Critical Facility and an ARIM-HFIR Remote Sampling Facility.

KC-Proposed construction summary

\begin{tabular}{|c|c|c|c|c|c|c|c|c|}
\hline ( $\$$ in Millions) & FY 1983 & FY 1984 & FY 1985 & FY 1986 & FY 1987 & FY 1988 & FY 1989 & TEC \\
\hline AIM-ORELA & & & & 0.6 & & & & 0.6 \\
\hline AMSL & & & & 2.8 & & & & 2.8 \\
\hline $\begin{array}{l}\text { ARIM-HFIR } \\
\text { Critical Facility }\end{array}$ & & & 0.3 & & & & & 0.3 \\
\hline ARIM-HFIR & & & 0.3 & & & & & 0.3 \\
\hline $\begin{array}{l}\text { Remote Sampling } \\
\text { Facility }\end{array}$ & & & & & & & & \\
\hline $\begin{array}{l}\text { Total proposed } \\
\text { construction }\end{array}$ & & & 0.6 & 3.4 & & & & 4.0 \\
\hline
\end{tabular}

\section{KD-Energy Research and Analysis}

Energy Research and Analysis activities support OER in technical and economic assessments of energy-related technologies; provide technical, logistic, and administrative support for ERAB; and fund technical analyses and other support for OER's continuing assessment of national R\&D on the effects of acid deposition on natural and man-influenced environments. No significant growth is projected for this program.

KD-Energy Research and Analysis Program resource summary

\begin{tabular}{|c|c|c|c|c|c|c|c|c|c|c|c|c|c|c|c|c|}
\hline \multirow{2}{*}{$\begin{array}{c}(\$ \text { in Millions })^{a} \\
(\text { Personnel in FTEs) }\end{array}$} & \multicolumn{2}{|c|}{ FY 1982} & \multicolumn{2}{|c|}{ FY 1983} & \multicolumn{2}{|c|}{ FY 1984} & \multicolumn{2}{|c|}{ FY 1985} & \multicolumn{2}{|c|}{ FY 1986} & \multicolumn{2}{|c|}{ FY 1987} & \multicolumn{2}{|c|}{ FY 1988} & \multicolumn{2}{|c|}{ FY 1989} \\
\hline & BA & BO & BA & BO & BA & BO & BA & BO & BA & BO & BA & BO & BA & BO & BA & BO \\
\hline Tota & 1.4 & 1.6 & & 1.0 & 1.1 & 1.1 & & 1.1 & & 1.1 & & & & 1.1 & & 1.1 \\
\hline Capita & 0.0 & & 0.0 & & 0.0 & & 0.0 & & 0.0 & & 0.0 & & 0.0 & & 0. & \\
\hline Construction & 0.0 & & 0.0 & & 0.0 & & 0.0 & & 0.0 & & 0.0 & & 0.0 & & 0.0 & \\
\hline $\begin{array}{l}\text { Total for major } \\
\text { programs }\end{array}$ & 1.4 & 1.6 & 1.3 & 1.0 & 1.1 & 1.1 & 1.1 & 1.1 & 1.1 & 1.1 & 1.1 & 1.1 & 1.1 & 1.1 & 1.1 & 1.1 \\
\hline Direct Personnel & 7.4 & & 5.2 & & 6.0 & & 6.0 & & 6.0 & & 6.0 & & 6.0 & & 6.0 & \\
\hline
\end{tabular}

${ }^{a}$ An $8.5 \%$ inflation factor has been used between FY 1983 and FY 1984 and between FY 1984 and FY 1985. FY 1986-FY 1989 amounts are in constant FY 1985 dollars.

\section{KE-University Research Support}

The University Research Support Program seeks to stimulate cooperative research by the university community in ORNL activities. Support is provided to involve students and faculty from the Southern College University Union and the Great Lakes College Association/Associated Colleges of the Midwest in ORNL research programs as well as to support student and faculty participation in the Reactor Training Cooperative Experiments and the Environmental Sciences Cooperative Curriculum. KE funds previously used for the MIT Practice School are now allocated to a special 
summer program for black undergraduate students to perform research at ORNL. This program is expected to remain stable through FY 1989.

KE-University Research Program resource summary

\begin{tabular}{|c|c|c|c|c|c|c|c|c|c|c|c|c|c|c|c|c|}
\hline \multirow{2}{*}{$\begin{array}{c}(\$ \text { in Millions })^{a} \\
\text { (Personnel in FTEs) }^{(2)}\end{array}$} & \multicolumn{2}{|c|}{ FY 1982} & \multicolumn{2}{|c|}{ FY 1983} & \multicolumn{2}{|c|}{ FY 1984} & \multicolumn{2}{|c|}{ FY 1985} & \multicolumn{2}{|c|}{ FY 1986} & \multicolumn{2}{|c|}{ FY 1987} & \multicolumn{2}{|c|}{ FY 1988} & \multicolumn{2}{|c|}{ FY 1989} \\
\hline & BA & BO & $\mathbf{B A}$ & BO & BA & BO & BA & BO & BA & BO & BA & BO & $\mathbf{B A}$ & BO & BA & BO \\
\hline Total Operating & 0.21 & 0.18 & 0.19 & 0.14 & 0.19 & 0.19 & 0.23 & 0.22 & 0.23 & 0.22 & 0.23 & 0.22 & 0.23 & 0.22 & 0.23 & 0.22 \\
\hline Capital Equipment & 0.0 & & 0.0 & & 0.0 & & 0.0 & & 0.0 & & 0.0 & & 0.0 & & 0.0 & \\
\hline Construction & 0.0 & & 0.0 & & 0.0 & & 0.0 & & 0.0 & & 0.0 & & 0.0 & & 0.0 & \\
\hline $\begin{array}{l}\text { Total for major } \\
\text { programs }\end{array}$ & 0.21 & 0.18 & 0.19 & 0.14 & 0.19 & 0.19 & 0.23 & 0.22 & 0.23 & 0.22 & 0.23 & 0.22 & 0.23 & 0.22 & 0.23 & 0.22 \\
\hline Direct Personnel & 0.9 & & 0.5 & & 2.5 & & 2.5 & & 2.5 & & 2.5 & & 2.5 & & 2.5 & \\
\hline
\end{tabular}

${ }^{\circ}$ An $8.5 \%$ inflation factor has been used between FY 1983 and FY 1984 and between FY 1984 and FY 1985. FY 1986-FY 1989 amounts are in constant FY 1985 dollars.

\section{Assistant Secretary for Nuclear Energy (ASNE)}

The ASNE is the major sponsor of applied nuclear research and the second largest sponsor at ORNL. Programs funded through this office are multidisciplinary in nature and include as major activities advanced nuclear systems, breeder reactor systems, converter reactor systems, remedial action programs, nuclear waste management, and nuclear fuel cycle programs. Some budget increases are expected; these are mostly due to increases for the Breeder Reprocessing Engineering Test and for the Light-Water Reactor (LWR) subprogram under Converter Reactor Systems (see Table 6). In addition, the Remedial Action Survey and Certification Activity (RASCA) has been transferred to ASNE under Remedial Action Programs.

Table 6. ASNE Major Program summary

( $\$$ in Millions-BA)

\begin{tabular}{|c|c|c|c|c|}
\hline B\& $R$ code & Major programs & FY 1983 & FY 1984 & FY 1985 \\
\hline $\mathrm{AE}$ & $\begin{array}{l}\text { Advanced Nuclear } \\
\text { Systems }\end{array}$ & 2.70 & 3.27 & 3.35 \\
\hline AF & $\begin{array}{l}\text { Breeder Reactor } \\
\text { Systems }\end{array}$ & 10.93 & 9.94 & 10.33 \\
\hline AG & $\begin{array}{l}\text { Converter Reactor } \\
\text { Systems }\end{array}$ & 7.11 & 9.69 & 9.51 \\
\hline $\mathbf{A H}$ & $\begin{array}{l}\text { Remedial Action } \\
\text { Programs }\end{array}$ & 1.52 & 3.93 & 3.61 \\
\hline $\mathbf{A P}$ & $\begin{array}{l}\text { Commercial Nuclear } \\
\text { Waste Management }\end{array}$ & 0.24 & 0.10 & 0.10 \\
\hline AS & Nuclear Fuel Cycle & 24.29 & 28.57 & 35.58 \\
\hline $\mathrm{CD}$ & Uranium Enrichment & 0.40 & 0.05 & 0.06 \\
\hline DA & $\begin{array}{l}\text { Nuclear Waste Disposal } \\
\text { Activities }\end{array}$ & 0.0 & 0.0 & 0.0 \\
\hline DB & Nuclear Waste Fund & 0.67 & 2.32 & 3.33 \\
\hline \multicolumn{2}{|c|}{ Total } & 47.86 & 57.87 & 65.87 \\
\hline \multicolumn{2}{|c|}{$\begin{array}{l}\text { Percent of total } \\
\text { Laboratory funding }- \text { BA }\end{array}$} & 13.5 & 14.6 & 14.0 \\
\hline
\end{tabular}

${ }^{a}$ Figures include operating BA, capital equipment, and funded/budgeted construction. 


\section{AE-Advanced Nuclear Systems}

Improved materials for space missions and terrestrial applications which utilize heat generated by isotopic power devices are being developed and evaluated. Activities include the production of iridium-alloy-cladding blanks to contain the heat-generating radioisotopes and carbon-bonded, carbon-fiber (CBCF) insulators to achieve the $1300^{\circ} \mathrm{C}$ operating temperature. Technology improvements being pursued include a process to produce CBCF from a new starting rayon product, a consumable arc-melting technique for the iridium alloy, publication of an Isotope Space Power Materials Handbook, and nondestructive-examination support for manufacture of advanced thermoelectric elements.

Efforts are also under way to establish a substantial role for ORNL in the DOD-DOE-National Aeronautics and Space Administration (NASA) space nuclear reactor systems program in the following technology areas: refractory alloys, Rankine cycle, reactor shielding, controls and measurements, and core design support. ORNL is expected to assume a lead role in the refractory alloys development program and important support roles in the other technology areas cited. Concept design and systems analysis are being handled exclusively by industrial contractor organizations.

AE-Advanced Nuclear Systems Program resource summary

\begin{tabular}{|c|c|c|c|c|c|c|c|c|c|c|c|c|c|c|c|c|}
\hline \multirow{2}{*}{$\begin{array}{c}(\$ \text { in Millions })^{a} \\
\text { (Personnel in FTEs) }\end{array}$} & \multicolumn{2}{|c|}{ FY 1982} & \multicolumn{2}{|c|}{ FY 1983} & \multicolumn{2}{|c|}{ FY 1984} & \multicolumn{2}{|c|}{ FY 1985} & \multicolumn{2}{|c|}{ FY 1986} & \multicolumn{2}{|c|}{ FY 1987} & \multicolumn{2}{|c|}{ FY 1988} & \multicolumn{2}{|c|}{ FY 1989} \\
\hline & BA & BO & BA & BO & $\mathbf{B A}$ & $\mathrm{BO}$ & BA & BO & BA & BO & $\mathrm{BA}$ & BO & BA & BO & BA & BO \\
\hline Total Operating & 1.7 & 2.7 & 2.6 & 3.1 & 2.7 & 2.6 & 3.2 & 3.2 & 4.0 & 4.0 & 4.0 & 4.0 & 4.0 & 4.0 & 4.0 & 4.0 \\
\hline Capital Equipment & 0.1 & & 0.05 & & 0.6 & & 0.1 & & 0.1 & & 0.1 & & 0.1 & & 0.1 & \\
\hline Construction & 0.0 & & 0.0 & & 0.0 & & 0.0 & & 0.0 & & 0.0 & & 0.0 & & 0.0 & \\
\hline $\begin{array}{l}\text { Total for major } \\
\text { programs }\end{array}$ & 1.8 & 2.7 & 2.7 & 3.1 & 3.3 & 2.6 & 3.3 & 3.2 & 4.1 & 4.0 & 4.1 & 4.0 & 4.1 & 4.0 & 4.1 & 4.0 \\
\hline Direct Personnel & 21.0 & & 22.0 & & 17.8 & & 21.7 & & 32.0 & & 32.0 & & 32.0 & & 32.0 & \\
\hline
\end{tabular}

${ }^{a}$ An $8.5 \%$ inflation factor has been used between FY 1983 and FY 1984 and between FY 1984 and FY 1985. FY 1986-FY 1989 amounts are in constant FY 1985 dollars.

\section{AF-Breeder Reactor Systems}

This program supports the liquid-metal fast-breeder reactor (LMFBR) concept with continued efforts in the traditional base-technology areas of materials and structures, measurements and controls, physics, and safety. In each of these areas, increased emphasis is being placed on activities that will contribute toward a more inherently safe and economically competitive breeder concept. In addition, the program provides technical support to specific projects, such as the Clinch River Breeder Reactor Plant (CRBRP).

As lead laboratory for the national Materials and Structures Program, we will continue efforts to develop and code-qualify advanced alloys, to obtain a greater understanding of the behavior of materials in LMFBR environments, and to develop improved design methods and criteria. Management of the national program will continue through the ORNL Materials and Structures Technology Management Center.

Measurements and controls activities will support the development and proof testing of key highrisk, high-payoff components and systems such as high-temperature fission counters and automated 
noise surveillance and diagnostic systems. The physics work will concentrate on analysis and validation of shield designs and determination of nuclear physics data. In the reactor safety area, thermal hydraulics data pertinent to the understanding and management of shutdown heat removal will be obtained from the Thermal Hydraulic Out-of-Reactor Safety (THORS) facility. Also, computerized data bases for safety analysis (SACRD) and component reliability (CREDO) will continue to be maintained.

The Nuclear Standards Management Center, which is part of the Program Assurance effort in the LMFBR Program, will continue to promote the development of consensus industrial standards - augmented by special program standards as required-to ensure that the information and experience gained in all nuclear programs-including fuel recycle and waste management-are documented appropriately and made available to the private sector. Program support for DOE's unusual-occurrence-report activities will be continued.

AF-Breeder Reactor Systems Program resource summary

\begin{tabular}{|c|c|c|c|c|c|c|c|c|c|c|c|c|c|c|c|c|}
\hline \multirow{2}{*}{$\begin{array}{l}(\$ \text { in Millions) } \\
\text { (Personnel in FTEs) }^{a}\end{array}$} & \multicolumn{2}{|c|}{ FY 1982} & \multicolumn{2}{|c|}{ FY 1983} & \multicolumn{2}{|c|}{ FY 1984} & \multicolumn{2}{|c|}{ FY 1985} & \multicolumn{2}{|c|}{ FY 1986} & \multicolumn{2}{|c|}{ FY 1987} & \multicolumn{2}{|c|}{ FY 1988} & \multicolumn{2}{|c|}{ FY 1989} \\
\hline & $\mathbf{B A}$ & BO & BA & BO & $\mathrm{BA}$ & BO & $\mathbf{B A}$ & BO & BA & BO & BA & $\mathrm{BO}$ & $\mathrm{BA}$ & BO & $\mathbf{B A}$ & BO \\
\hline Total Operating & 12.4 & 11.5 & 10.8 & 12.9 & 9.3 & 10.0 & 10.0 & 10.0 & 10.0 & 10.0 & 10.0 & 10.0 & 10.0 & 10.0 & 10.0 & 10.0 \\
\hline Capital Equipment & 0.6 & & 0.07 & & 0.6 & & 0.3 & & 0.3 & & 0.3 & & 0.3 & & 0.3 & \\
\hline Construction & 0.0 & & 0.0 & & 0.0 & & 0.0 & & 0.0 & & 0.0 & & 0.0 & & 0.0 & \\
\hline $\begin{array}{l}\text { Total for major } \\
\text { programs }\end{array}$ & 13.0 & 11.5 & 10.9 & 12.9 & 9.9 & 10.0 & 10.3 & 10.0 & 10.3 & 10.0 & 10.3 & 10.0 & 10.3 & 10.0 & 10.3 & 10.0 \\
\hline Direct Personnel & 85.0 & & 83.0 & & 72.8 & & 72.8 & & 72.8 & & 72.8 & & 72.8 & & 72.8 & \\
\hline
\end{tabular}

${ }^{a}$ An $8.5 \%$ inflation factor has been used between FY 1983 and FY 1984 and between FY 1984 and FY 1985. FY 1986-FY 1989 amounts are in constant FY 1985 dollars.

\section{$A G-C o n v e r t e r$ Reactor Systems}

The primary mission of this activity is to provide technological expertise in support of the national program to develop high-temperature gas-cooled reactors (HTGRs) for cogeneration and hightemperature process heat. The technical activities include: (1) performing qualification tests of HTGR fuel behavior under design and off-design reactor conditions; (2) providing basic data on the mechanical, physical, and chemical behavior of HTGR materials, including metals, ceramics, graphite, and concrete; (3) performing component testing and development on the core support structure and on the ceramic pads on which the core parts rest; (4) providing experimental evaluation of the shielding effectiveness of the lower portions of the HTGR core region; (5) developing welding techniques for cladding steam generator tube sheets and for attaching tubing to the tube sheets; and (6) providing technical evaluations and assessments in specific as well as broad areas.

An ancillary task, a part of the LWR subprogram, is to reexamine the advantages of a small LWR in meeting the growth requirements of the utility industry. Other LWR tasks include annual updating of the Energy Economic Data Base (EEDB), economic analyses of nuclear vs other energy sources, and a region-specific study of the electric utility industry. The latter is aimed at assurance of adequate future electric power. The increases in funding for the AG program reflect a modest increase in the evaluation and assessment activities and consolidation of funding in this area. Funding for the HTGR program is expected to be static. 
Activities in the Convertor Reactor Systems Program have achieved several major accomplishments this year. The Component Flow Test Loop has been modified to accomodate the Core Support Performance Test. This modification will allow study of the response of the HTGR core support structure to simulated long-term reactor behavior. We have also carried out experimental shielding studies of the lower regions of the HTGR core support and found that the design fluence of thermal neutrons should be increased by about a factor of 10 . Finally, we have applied fracture mechanics and statistical theory to graphite. This research has resulted in graphites with greater strengths and in reduced variances in strength throughout a graphite log.

Recognizing the extended delay in LWR plant orders and the eventual need for more advanced reactor systems, we propose new activity to examine several new and modified concepts. Emphasis will be placed on lower costs, improved fuel utilization, application to process and district heating, improved siting capability, and improved thermal efficiency. Concepts to be considered include sodium- and gas-cooled reactors and modified LWRs, such as the Process Inherent Ultimate Safety (PIUS) concept proposed by Sweden. This modest effort will be coordinated with similar studies by TVA, the Electric Power Research Institute (EPRI), and other segments of industry.

AG-Converter Reactor Systems Program resource summary

\begin{tabular}{|c|c|c|c|c|c|c|c|c|c|c|c|c|c|c|c|c|}
\hline \multirow{2}{*}{$\begin{array}{c}(\$ \text { in Millions })^{a} \\
(\text { Personnel in FTEs })\end{array}$} & \multicolumn{2}{|c|}{ FY 1982} & \multicolumn{2}{|c|}{ FY 1983} & \multicolumn{2}{|c|}{ FY 1984} & \multicolumn{2}{|c|}{ FY 1985} & \multicolumn{2}{|c|}{ FY 1986} & \multicolumn{2}{|c|}{ FY 1987} & \multicolumn{2}{|c|}{ FY 1988} & \multicolumn{2}{|c|}{ FY 1989} \\
\hline & $\mathbf{B A}$ & $\mathrm{BO}$ & BA & $\mathrm{BO}$ & BA & BO & BA & BO & BA & $\mathrm{BO}$ & BA & BO & BA & $\mathrm{BO}$ & BA & BO \\
\hline Total Operating & 5.1 & 5.8 & 5.8 & 6.1 & 7.4 & 6.5 & 7.7 & 7.5 & 8.2 & 7.9 & 7.9 & 7.9 & 7.9 & 7.9 & 7.9 & 7.9 \\
\hline Capital Equipment & 0.9 & & 1.3 & & 2.3 & & 1.8 & & 1.8 & & 2.0 & & 1.8 & & 2.0 & \\
\hline Construction & 0.0 & & 0.0 & & 0.0 & & 0.0 & & 0.0 & & 0.0 & & 0.0 & & 0.0 & \\
\hline $\begin{array}{l}\text { Total for major } \\
\text { programs }\end{array}$ & 6.0 & 5.8 & 7.1 & 6.1 & 9.7 & 6.5 & 9.5 & 7.5 & 10.0 & 7.9 & 9.9 & 7.9 & 9.7 & 7.9 & 9.9 & 7.9 \\
\hline Direct Personnel & 39.1 & & 34.7 & & 38.1 & & 38.3 & & 41.3 & & 41.3 & & 41.3 & & 41.3 & \\
\hline
\end{tabular}

${ }^{a}$ An $8.5 \%$ inflation factor has been used between FY 1983 and FY 1984 and between FY 1984 and FY 1985. FY 1986 FY 1989 amounts are in constant FY 1985 dollars.

\section{AH-Remedial Action Program}

The major activities in this program involve work associated with former DOE/Atomic Energy Commission (AEC) sites and with management of surplus DOE facilities. Increased funding is anticipated in the latter program beginning in FY 1988 and continuing through FY 1989 as the decommissioning of two ORNL facilities, the Molten Salt Reactor Experiment and the Fission Product Development Laboratory, will be initiated.

The substantial increase in funding between FY 1983 and FY 1984 is due to the addition of the RASCA task, which will be transferred to this program in FY 1984. It will continue to perform radiological surveys at sites formerly used under contract with the $A E C$, at inactive uranium mill sites, surplus DOE sites, and private properties in the vicinity of these sites. The funding for this task is expected to be stable throughout the planning period. 
AH-Remedial Action Program resource summary

\begin{tabular}{|c|c|c|c|c|c|c|c|c|c|c|c|c|c|c|c|c|}
\hline \multirow{2}{*}{$\begin{array}{c}(\$ \text { in Millions })^{a} \\
(\text { Personnel in FTEs) }\end{array}$} & \multicolumn{2}{|c|}{ FY 1982} & \multicolumn{2}{|c|}{ FY 1983} & \multicolumn{2}{|c|}{ FY 1984} & \multicolumn{2}{|c|}{ FY 1985} & \multicolumn{2}{|c|}{ FY 1986} & \multicolumn{2}{|c|}{ FY 1987} & \multicolumn{2}{|c|}{ FY 1988} & \multicolumn{2}{|c|}{ FY 1989} \\
\hline & BA & BO & BA & BO & BA & BO & BA & BO & BA & BO & BA & BO & BA & BO & BA & BO \\
\hline Total Operating & 0.4 & 0.6 & 1.5 & 1.1 & 3.9 & 3.4 & 3.6 & 3.6 & 3.6 & 3.6 & 3.6 & 3.6 & 4.5 & 4.3 & 5.1 & 4.9 \\
\hline Capital Equipment & 0.0 & & 0.0 & & 0.03 & & 0.01 & & 0.1 & & 0.1 & & 0.0 & & 0 & \\
\hline Construction & 0.0 & & 0.0 & & 0.0 & & 0.0 & & 0.0 & & 0.0 & & 0.0 & & 0.0 & \\
\hline $\begin{array}{l}\text { Total for major } \\
\text { programs }\end{array}$ & 0.04 & 0.6 & 1.5 & 1.1 & 3.9 & 3.4 & 3.6 & 3.6 & 3.7 & 3.6 & 3.7 & 3.6 & 4.5 & 4.3 & 5.1 & 4.9 \\
\hline Direct Personnel & 5.8 & & 6.2 & & 18.5 & & 18.5 & & 18.5 & & 18.5 & & 21.5 & & 25.0 & \\
\hline
\end{tabular}

${ }^{a}$ An $8.5 \%$ inflation factor has been used between FY 1983 and FY 1984 and between FY 1984 and FY 1985. FY 1986-FY 1989 amounts are in constant FY 1985 dollars.

\section{AP-Commercial Nuclear Waste Management}

Two main tasks have been partially funded under this program: the Integrated Data Base (IDB) and Waste Transportation Studies. Effective in mid-FY 1983, the latter task was transferred to a new program (DB). The IDB is expected to remain stable. The low level of effort listed in AP for the IDB reflects the fact that this task is also funded under other program codes (AF, AH, AR, and AS), with the Assistant Secretary for Defense Programs being the major sponsor.

In addition, under the AP activity code, ORNL will provide consultation to the State of Kentucky for a demonstration of in-situ grouting of a low-level waste trench. The Field-Scale Demonstration will show that an existing trench can be successfully and safely stabilized. ORNL will consult on overall planning, grout selection and emplacement, data evaluation, and postgrout testing.

AP-Commercial Nuclear Waste Management Program resource summary

\begin{tabular}{|c|c|c|c|c|c|c|c|c|c|c|c|c|c|c|c|c|}
\hline \multirow{2}{*}{$\begin{array}{c}(\$ \text { in Millions })^{a} \\
(\text { Personnel in FTEs) }\end{array}$} & \multicolumn{2}{|c|}{ FY 1982} & \multicolumn{2}{|c|}{ FY 1983} & \multicolumn{2}{|c|}{ FY 1984} & \multicolumn{2}{|c|}{ FY 1985} & \multicolumn{2}{|c|}{ FY 1986} & \multicolumn{2}{|c|}{ FY 1987} & \multicolumn{2}{|c|}{ FY 1988} & \multicolumn{2}{|c|}{ FY 1989} \\
\hline & BA & BO & BA & BO & BA & BO & BA & BO & BA & BO & BA & BO & BA & BO & BA & $\mathrm{BO}$ \\
\hline Total Operating & 1.0 & 1.3 & 0.2 & 0.2 & 0.1 & 0.1 & 0.1 & 0.1 & 0.1 & 0.1 & 0.1 & 0.1 & 0.1 & 0.1 & 0.1 & 0.1 \\
\hline Capital Equipment & 0.2 & & 0.0 & & 0.0 & & 0.0 & & 0.0 & & 0.0 & & 0.0 & & 0.0 & \\
\hline Construction & 0.0 & & 0.0 & & 0.0 & & 0.0 & & 0.0 & & 0.0 & & 0.0 & & 0.0 & \\
\hline $\begin{array}{l}\text { Total for major } \\
\text { programs }\end{array}$ & 1.2 & 1.3 & 0.2 & 0.2 & 0.1 & 0.1 & 0.1 & 0.1 & 0.1 & 0.1 & 0.1 & 0.1 & 0.1 & 0.1 & 0.1 & 0.1 \\
\hline Direct Personnel & 9.4 & & 0.0 & & 0.6 & & 0.6 & & 0.6 & & 0.6 & & 0.6 & & 0.6 & \\
\hline
\end{tabular}

${ }^{a}$ An $8.5 \%$ inflation factor has been used between FY 1983 and FY 1984 and between FY 1984 and FY 1985. FY 1986-FY 1989 amounts are in constant FY 1985 dollars.

\section{AS-Nuclear Fuel Cycle}

The predominant activity under the Nuclear Fuel Cycle Program is development of nuclear fuel reprocessing. Reprocessing development, centered on the Consolidated Fuel Reprocessing Program (CFRP), is one of ORNL's most important efforts. ORNL manages the national effort in reprocessing R\&D for DOE in the CFRP. ORNL's experienced designers and engineers have made, and will continue to make, significant contributions to this technology with their innovative improvements. The Breeder Reprocessing Engineering Test, a major new DOE initiative, provides a clear focal point for this development program. 
BRET will demonstrate advanced reprocessing technology and closing of the fuel cycle with spent fuel from the Fast-Flux Test Facility (FFTF) and other demonstration reactors. The project, a joint effort with the Hanford Engineering Development Laboratory (HEDL), will be installed in an existing facility at Hanford, Washington. It will be a limited-scale, $100-\mathrm{kg} / \mathrm{d}$ facility. BRET will be both a technical and administrative challenge. From the technical standpoint, several major ongoing development activities must be completed and process equipment must be installed in an existing confined space on a reasonably short schedule. Hot operation is planned for the early 1990s. Because advanced remote maintenance methods must be used, the related R\&D at ORNL must be successful and timely. ORNL will design, procure, and test the bulk of the processing equipment before it is sent to HEDL. The Integrated Equipment Test (IET) Facility at ORNL will be instrumental in this development and proof testing.

The administrative challenge of BRET has two aspects. First, organization and responsibility for BRET must be divided between two field offices (Oak Ridge Operations and Richland Operations) and two contractors (ORNL and HEDL). The resulting complex management situation will require continued attention and thoughtful cooperation to ensure success of the project. Second, the current funding strategy for BRET involves a combination of operating, equipment, and capital funds. This funding method will require careful planning and coordination among the project participants and with DOE and congressional staffs to ensure that appropriations are supplied, as needed, over the life of the project.

With the overall slower pace of the breeder program in the United States, the BRET project provides an outstanding opportunity for closing the fuel cycle for existing reactors and an excellent test bed for many of the advanced concepts that have been under development for several years at ORNL. BRET will be the focal point of the fuel cycle efforts for the next 10 to 15 years. Beyond this time frame, activities will depend on future decisions with respect to the breeder program. Efforts to foster international collaboration and examine the merits of cooperative fuel cycle projects in the future will continue. Major new agreements signed this past year with Japan enable collaboration in experimental criticality work and in application of remote technology to reprocessing. Japan (Power Reactor and Nuclear Fuel Development Corporation) will provide major funding for the criticality program. Activities under the United Kingdom exchange have continued.

A small part of the AS Program funding provides a portion of the total funding for the IDB. The AS portion amounts to about $5 \%$ of the IDB total. Support for the IDB cuts across many functional areas, with the AR [Assistant Secretary for Defense Program (ASDP)] Program representing the largest single source of funding $(50 \%)$.

AS-Nuclear Fuel Cycle Program resource summary

\begin{tabular}{|c|c|c|c|c|c|c|c|c|c|c|c|c|c|c|c|c|}
\hline \multirow{2}{*}{$\begin{array}{c}(\$ \text { in Millions })^{a} \\
\text { (Personnel in FTEs) }\end{array}$} & \multicolumn{2}{|c|}{ FY 1982} & \multicolumn{2}{|c|}{ FY 1983} & \multicolumn{2}{|c|}{ FY 1984} & \multicolumn{2}{|c|}{ FY 1985} & \multicolumn{2}{|c|}{ FY 1986} & \multicolumn{2}{|c|}{ FY 1987} & \multicolumn{2}{|c|}{ FY 1988} & \multicolumn{2}{|c|}{ FY 1989} \\
\hline & BA & BO & BA & BO & BA & BO & BA & BO & $\mathbf{B A}$ & BO & BA & BO & $\mathbf{B A}$ & BO & BA & BO \\
\hline Total Operating & 22.9 & 22.6 & 20.7 & 21.1 & 25.6 & 25.3 & 25.6 & 25.3 & 25.7 & 25.4 & 26.4 & 26.4 & 26.4 & 26.4 & 26.5 & 26.5 \\
\hline Capital Equipment & 3.0 & & 3.6 & & 3.0 & & 10.0 & & 3.0 & & 3.0 & & 3.0 & & 3.0 & \\
\hline Construction & 0.0 & & 0.0 & & 0.0 & & 0.0 & & 0.0 & & 0.0 & & 0.0 & & 0.0 & \\
\hline $\begin{array}{l}\text { Total for major } \\
\text { programs }\end{array}$ & 25.9 & 22.6 & 24.3 & 21.1 & 28.6 & 25.3 & $35.6^{\circ}$ & 25.3 & 28.7 & 25.4 & 29.4 & 26.4 & 29.4 & 26.4 & 29.5 & 26.5 \\
\hline Direct Personnel & 131.6 & & 115.3 & & 130.2 & & 142.4 & & 145.4 & & 152.4 & & 152.4 & & 153.4 & \\
\hline
\end{tabular}

${ }^{\circ}$ An $8.5 \%$ inflation factor has been used between FY 1983 and FY 1984 and between FY 1984 and FY 1985. FY 1986-FY 1989 amounts are in constant FY 1985 dollars. 


\section{CD-Uranium Enrichment}

This program is concerned with recovery of uranium as a by-product from wet-process phosphoric acid production in the fertilizer industry. Although the method is being used extensively in the commercial sector, ORNL is seeking further improvements to make the process more amenable to the smaller operator. This activity will be terminated after FY 1985.

CD-Uranium Enrichment Program resource summary

\begin{tabular}{|c|c|c|c|c|c|c|c|c|c|c|c|c|c|c|c|c|}
\hline \multirow{2}{*}{$\begin{array}{c}(\$ \text { in Millions })^{a} \\
(\text { Personnel in FTEs) }\end{array}$} & \multicolumn{2}{|c|}{ FY 1982} & \multicolumn{2}{|c|}{ FY 1983} & \multicolumn{2}{|c|}{ FY 1984} & \multicolumn{2}{|c|}{ FY 1985} & \multicolumn{2}{|c|}{ FY 1986} & \multicolumn{2}{|c|}{ FY 1987} & \multicolumn{2}{|c|}{ FY 1988} & \multicolumn{2}{|c|}{ FY 1989} \\
\hline & BA & BO & BA & BO & BA & BO & BA & BO & BA & BO & BA & BO & BA & BO & BA & BO \\
\hline Total Operating & 0.5 & 0.4 & 0.4 & 0.5 & 0.05 & 0.05 & 0.06 & 0.06 & 0.0 & 0.0 & 0.0 & 0.0 & 0.0 & 0.0 & 0.0 & 0.0 \\
\hline Capital Equipment & 0.0 & & 0.0 & & 0.0 & & 0.0 & & 0.0 & & 0.0 & & 0.0 & & 0.0 & \\
\hline Construction & 0.0 & & 0.0 & & 0.0 & & 0.0 & & 0.0 & & 0.0 & & 0.0 & & 0.0 & \\
\hline $\begin{array}{l}\text { Total for major } \\
\text { programs }\end{array}$ & 0.5 & 0.4 & 0.4 & 0.5 & 0.05 & 0.05 & 0.06 & 0.06 & 0.0 & 0.0 & 0.0 & 0.0 & 0.0 & 0.0 & 0.0 & 0.0 \\
\hline Direct Personnel & 1.0 & & 0.8 & & 0.3 & & 0.4 & & 0.0 & & 0.0 & & 0.0 & & 0.0 & \\
\hline
\end{tabular}

${ }^{\circ}$ An $8.5 \%$ inflation factor has been used between FY 1983 and FY 1984 and between FY 1984 and FY 1985. FY 1986 FY 1989 amounts are in constant FY 1985 dollars.

\section{DA/DB-Nuclear Waste Disposal Activities/Nuclear Waste Fund}

Program DA was created in FY 1983 to fund terminal isolation development studies and environmental characterization of selected regions considered eligible for siting of nuclear waste repositories. This work was funded in FY 1982 in Program AP but is included here for the purpose of continuity. In mid-FY 1983 the entire program was folded into a new program, DB, which was created to accomodate the tasks involved in the Nuclear Waste Fund Program established by the National Waste Policy Act of 1982. The principal new task, which is planned to commence in FY 1984, will be generic in nature; its major thrust will be to examine the feasibility of utilizing argillaceous rock that occurs in the eastern United States as a host medium for the storage of radioactive waste. The investigation will begin with an extensive literature survey followed by a careful selection of suitable candidates for detailed physical and chemical characterization. Operating costs are expected to be $\$ 1.9 \mathrm{M}$ in FY 1984, with a step to $\$ 2.8 \mathrm{M}$ in FY 1985.

\section{DA-Nuclear Waste Disposal Activities Program resource summary}

\begin{tabular}{|c|c|c|c|c|c|c|c|c|c|c|c|c|c|c|c|c|}
\hline \multirow{2}{*}{$\begin{array}{c}(\$ \text { in Millions) })^{a} \\
\text { (Personnel in FTEs) }\end{array}$} & \multicolumn{2}{|c|}{ FY 1982} & \multicolumn{2}{|c|}{ FY 1983} & \multicolumn{2}{|c|}{ FY 1984} & \multicolumn{2}{|c|}{ FY 1985} & \multicolumn{2}{|c|}{ FY 1986} & \multicolumn{2}{|c|}{ FY 1987} & \multicolumn{2}{|c|}{ FY 1988} & \multicolumn{2}{|c|}{ FY 1989} \\
\hline & BA & BO & BA & BO & BA & BO & BA & BO & BA & BO & BA & BO & BA & $\mathrm{BO}$ & BA & $\mathrm{BO}$ \\
\hline Total Operating & 0.8 & 0.8 & 0.0 & 0.09 & 0.0 & 0.0 & 0.0 & 0.0 & 0.0 & 0.0 & 0.0 & 0.0 & 0.0 & 0.0 & 0.0 & 0.0 \\
\hline Capital Equipment & 0.0 & & 0.0 & & 0.0 & & 0.0 & & 0.0 & & 0.0 & & 0.0 & & 0.0 & \\
\hline Construction & 0.0 & & 0.0 & & 0.0 & & 0.0 & & 0.0 & & 0.0 & & 0.0 & & 0.0 & \\
\hline $\begin{array}{l}\text { Total for major } \\
\text { programs }\end{array}$ & 0.8 & 0.8 & 0.0 & 0.09 & 0.0 & 0.0 & 0.0 & 0.0 & 0.0 & 0.0 & 0.0 & 0.0 & 0.0 & 0.0 & 0.0 & 0.0 \\
\hline Direct Personnel & 6.5 & & 0.0 & & 0.0 & & 0.0 & & 0.0 & & 0.0 & & 0.0 & & 0.0 & \\
\hline
\end{tabular}

${ }^{a}$ An $8.5 \%$ inflation factor has been used between FY 1983 and FY 1984 and between FY 1984 and FY 1985. FY 1986-FY 1989 amounts are in constant FY 1985 dollars. 
DB-Nuclear Waste Fund Program resource summary

\begin{tabular}{|c|c|c|c|c|c|c|c|c|c|c|c|c|c|c|c|c|}
\hline \multirow{2}{*}{$\begin{array}{c}(\$ \text { in Millions) })^{a} \\
\text { (Personnel in FTEs) }\end{array}$} & \multicolumn{2}{|c|}{ FY 1982} & \multicolumn{2}{|c|}{ FY 1983} & \multicolumn{2}{|c|}{ FY 1984} & \multicolumn{2}{|c|}{ FY 1985} & \multicolumn{2}{|c|}{ FY 1986} & \multicolumn{2}{|c|}{ FY 1987} & \multicolumn{2}{|c|}{ FY 1988} & \multicolumn{2}{|c|}{ FY 1989} \\
\hline & BA & BO & BA & BO & BA & BO & $\mathbf{B A}$ & BO & BA & BO & BA & BO & BA & BO & $\mathbf{B A}$ & BO \\
\hline Total Operating & 0.0 & 0.0 & 0.7 & 0.5 & 2.3 & 1.9 & 3.3 & 2.8 & 3.7 & 3.5 & 6.0 & 5.4 & 5.6 & 5.6 & 5.6 & 5.6 \\
\hline Capital Equipment & 0.0 & & 0.0 & & 0.0 & & 0.0 & & 0.0 & & 0.0 & & 0.0 & & 0.0 & \\
\hline Construction & 0.0 & & 0.0 & & 0.0 & & 0.0 & & 0.0 & & 0.0 & & 0.0 & & 0.0 & \\
\hline $\begin{array}{l}\text { Total for major } \\
\text { programs }\end{array}$ & 0.0 & 0.0 & 0.7 & 0.5 & 2.3 & 1.9 & 3.3 & 2.8 & 3.7 & 3.5 & 6.0 & 5.4 & 5.6 & 5.6 & 5.6 & 5.6 \\
\hline Direct Personnel & 0.0 & & 4.4 & & 11.0 & & 17.5 & & 23.0 & & 35.5 & & 36.7 & & 36.7 & \\
\hline
\end{tabular}

${ }^{a}$ An $8.5 \%$ inflation factor has been used between FY 1983 and FY 1984 and between FY 1984 and FY 1985 FY 1986-FY 1989 amounts are in constant FY 1985 dollars.

\section{Assistant Secretary for Defense Programs}

The major effort for this office is in defense waste management and may be divided into two main categories: (1) management of wastes generated at ORNL and (2) materials production involving administration of the national repository for uranium-233 and (in the short term) conversion of $100 \mathrm{~kg}$ of uranium from liquid to inert solid. The ORNL Fusion Program will also receive some funding through the ASDP for a gyrotron development project for FY 1984-FY 1986. This funding is incorporated in the GE Program budget (see Table 7) but will be subcontracted.

Table 7. ASDP Major Program summary"

( $\$$ in Millions-BA)

\begin{tabular}{|c|c|c|c|c|}
\hline B\& $R$ code & Major programs & FY 1983 & FY 1984 & FY 1985 \\
\hline AR & $\begin{array}{l}\text { Defense Waste } \\
\text { Management }\end{array}$ & 24.76 & 24.73 & 25.14 \\
\hline GC & $\begin{array}{l}\text { Verification and } \\
\text { Control Technology }\end{array}$ & 0.07 & 0.03 & 0.03 \\
\hline GD & $\begin{array}{l}\text { Nuclear Materials } \\
\text { Security and } \\
\text { Safeguards }\end{array}$ & 0.04 & 0.0 & 0.0 \\
\hline GE & Materials Production & 5.65 & 9.20 & 10.86 \\
\hline \multicolumn{2}{|c|}{ Total } & 30.52 & 33.96 & 36.03 \\
\hline \multicolumn{2}{|c|}{$\begin{array}{l}\text { Percent of total } \\
\text { Laboratory funding - BA }\end{array}$} & 8.6 & 8.6 & 7.7 \\
\hline
\end{tabular}

${ }^{a}$ Figures include operating BA, capital equipment, and funded/ budgeted construction.

\section{AR-Defense Waste Management}

The long-term objective of the ORNL waste management operations program is to ensure that radioactive waste generated at ORNL will be stored or disposed of in a safe and environmentally acceptable manner. The operating expense budget authority is scheduled to increase between FY 1984 and FY 1985 primarily because of intensified activity in the storage and disposal operations and decontamination and decommissioning areas. A significant drop is expected in FY 1986, after which time the budget will remain constant. 
AR-Defense Waste Management Program resource summary

\begin{tabular}{|c|c|c|c|c|c|c|c|c|c|c|c|c|c|c|c|c|}
\hline \multirow{2}{*}{$\begin{array}{c}(\$ \text { in Millions })^{a} \\
(\text { Personnel in FTEs) }\end{array}$} & \multicolumn{2}{|c|}{ FY 1982} & \multicolumn{2}{|c|}{ FY 1983} & \multicolumn{2}{|c|}{ FY 1984} & \multicolumn{2}{|c|}{ FY 1985} & \multicolumn{2}{|c|}{ FY 1986} & \multicolumn{2}{|c|}{ FY 1987} & \multicolumn{2}{|c|}{ FY 1988} & \multicolumn{2}{|c|}{ FY 1989} \\
\hline & $\mathrm{BA}$ & $\mathrm{BO}$ & $\mathbf{B A}$ & $\mathrm{BO}$ & $\mathbf{B A}$ & BO & BA & $\mathrm{BO}$ & $\mathbf{B A}$ & $\mathrm{BO}$ & $\mathbf{B A}$ & $\mathrm{BO}$ & $\mathbf{B A}$ & $\mathrm{BO}$ & BA & BO \\
\hline Total Operating & 15.7 & 16.3 & 18.5 & 18.3 & 19.3 & 19.6 & 23.5 & 22.7 & 21.5 & 21.6 & 21.0 & 21.2 & 20.5 & 20.6 & 20.2 & 20.2 \\
\hline Capital Equipment & 0.5 & & 1.3 & & 1.4 & & 1.6 & & 1.2 & & 1.0 & & 0.9 & & 0.9 & \\
\hline Construction $^{b}$ & 7.0 & & 5.0 & & 4.0 & & 0.0 & & 0.0 & & 0.0 & & 0.0 & & 0.0 & \\
\hline $\begin{array}{l}\text { Total for major } \\
\text { programs }\end{array}$ & 23.2 & 16.3 & 24.8 & 18.3 & 24.7 & 19.6 & 25.1 & 22.7 & 22.7 & 21.6 & 22.0 & 21.2 & 21.4 & 20.6 & 21.1 & 20.2 \\
\hline Direct Personnel & 120.6 & & 126.5 & & 128.0 & & 132.0 & & 129.0 & & 128.0 & & 127.0 & & 124.0 & \\
\hline
\end{tabular}

${ }^{a}$ An $8.5 \%$ inflation factor has been used between FY 1983 and FY 1984 and between FY 1984 and FY 1985. FY $1986-F Y$ 1989 amounts are in constant FY 1985 dollars.

${ }^{b}$ Does not include proposed construction.

Program Construction. The Radioactive Waste Facilities Improvement project is funded and ongoing. A Central Waste Disposal Facility is proposed as an FY 1986 line-item project. In addition, FY 1983-FY 1989 waste management GPP funding is, for the purposes of this plan, treated as proposed construction.

AR-Funded construction summary

\begin{tabular}{|c|c|c|c|c|c|c|c|c|c|}
\hline ( $\$$ in Millions) & FY 1982 & FY 1983 & FY 1984 & FY 1985 & FY 1986 & FY 1987 & FY 1988 & FY 1989 & TEC \\
\hline $\begin{array}{l}\text { Radioactive } \\
\text { waste facilities } \\
\text { improvements }\end{array}$ & 7.0 & 5.0 & 4.0 & & & & & & 22.3 \\
\hline $\begin{array}{l}\text { Total funded } \\
\text { construction }\end{array}$ & 7.0 & 5.0 & 4.0 & & & & & & 22.3 \\
\hline
\end{tabular}

AR-Proposed construction summary

\begin{tabular}{|c|c|c|c|c|c|c|c|c|c|}
\hline ( $\$$ in Millions) & FY 1982 & FY 1983 & FY 1984 & FY 1985 & FY 1986 & FY 1987 & FY 1988 & FY 1989 & TEC \\
\hline $\begin{array}{l}\text { Central Waste } \\
\text { Disposal Facility }\end{array}$ & & & & & 1.0 & 3.5 & 3.0 & & 7.5 \\
\hline $\begin{array}{l}\text { Waste Management } \\
\text { GPP }\end{array}$ & 0.8 & 2.0 & 1.8 & 2.5 & 2.5 & 2.5 & 2.5 & 2.5 & $\mathrm{NA}^{a}$ \\
\hline
\end{tabular}

${ }^{a} \mathrm{NA}=$ not applicable.

\section{GC-Verification and Control Technology}

This program is a very minor effort but will continue as long as various agencies remain interested in the general area of verification and control of technology. The program is expected to continue on a yearly basis throughout the planning cycle. 
GC-Verification and Control Technology Program resource summary

\begin{tabular}{|c|c|c|c|c|c|c|c|c|c|c|c|c|c|c|c|c|}
\hline \multirow{2}{*}{$\begin{array}{c}(\$ \text { in Millions })^{a} \\
\text { (Personnel in FTEs) }\end{array}$} & \multicolumn{2}{|c|}{ FY 1982} & \multicolumn{2}{|c|}{ FY 1983} & \multicolumn{2}{|c|}{ FY 1984} & \multicolumn{2}{|c|}{ FY 1985} & \multicolumn{2}{|c|}{ FY 1986} & \multicolumn{2}{|c|}{ FY 1987} & \multicolumn{2}{|c|}{ FY 1988} & \multicolumn{2}{|c|}{ FY 1989} \\
\hline & BA & BO & BA & $\mathrm{BO}$ & BA & BO & BA & BO & BA & BO & BA & BO & BA & BO & BA & $\mathrm{BO}$ \\
\hline Total Operating & 0.06 & 0.05 & 0.07 & 0.05 & 0.03 & 0.03 & 0.03 & 0.03 & 0.03 & 0.03 & 0.03 & 0.03 & 0.03 & 0.03 & 0.03 & 0.03 \\
\hline Capital Equipment & 0.0 & & 0.0 & & 0.0 & & 0.0 & & 0.0 & & 0.0 & & 0.0 & & 0.0 & \\
\hline Construction & 0.0 & & 0.0 & & 0.0 & & 0.0 & & 0.0 & & 0.0 & & 0.0 & & 0.0 & \\
\hline $\begin{array}{l}\text { Total for major } \\
\text { programs }\end{array}$ & 0.06 & 0.05 & 0.07 & 0.05 & 0.03 & 0.03 & 0.03 & 0.03 & 0.03 & 0.03 & 0.03 & 0.03 & 0.03 & 0.03 & 0.03 & 0.03 \\
\hline Direct Personnel & 0.5 & & 0.4 & & 0.1 & & 0.1 & & 0.1 & & 0.1 & & 0.1 & & 0.1 & \\
\hline
\end{tabular}

${ }^{a}$ An 8.5\% inflation factor has been used between FY 1983 and FY 1984 and between FY 1984 and FY 1985. FY 1986-FY 1989 amounts are in constant FY 1985 dollars.

\section{GD-Nuclear Materials Security and Safeguards}

Funding in this program is expected to be terminated with the completion of the resin bead loading verification tests.

GD-Nuclear Materials Security and Safeguards Program resource summary

\begin{tabular}{|c|c|c|c|c|c|c|c|c|c|c|c|c|c|c|c|c|}
\hline \multirow{2}{*}{$\begin{array}{c}(\$ \text { in Millions })^{a} \\
(\text { Personnel in FTEs })\end{array}$} & \multicolumn{2}{|c|}{ FY 1982} & \multicolumn{2}{|c|}{ FY 1983} & \multicolumn{2}{|c|}{ FY 1984} & \multicolumn{2}{|c|}{ FY 1985} & \multicolumn{2}{|c|}{ FY 1986} & \multicolumn{2}{|c|}{ FY 1987} & \multicolumn{2}{|c|}{ FY 1988} & \multicolumn{2}{|c|}{ FY 1989} \\
\hline & BA & BO & BA & BO & BA & BO & BA & $\mathrm{BO}$ & BA & BO & BA & $\mathrm{BO}$ & BA & BO & BA & $\mathrm{BO}$ \\
\hline Total Operating & 0.20 & 0.17 & 0.04 & 0.04 & 0.0 & 0.0 & 0.0 & 0.0 & 0.0 & 0.0 & 0.0 & 0.0 & 0.0 & 0.0 & 0.0 & 0.0 \\
\hline Capital Equipment & 0.03 & & 0.0 & & 0.0 & & 0.0 & & 0.0 & & 0.0 & & 0.0 & & 0.0 & \\
\hline Construction & 0.0 & & 0.0 & & 0.0 & & 0.0 & & 0.0 & & 0.0 & & 0.0 & & 0.0 & \\
\hline $\begin{array}{l}\text { Total for major } \\
\text { programs }\end{array}$ & 0.23 & 0.17 & 0.04 & 0.04 & 0.0 & 0.0 & 0.0 & 0.0 & 0.0 & 0.0 & 0.0 & 0.0 & 0.0 & 0.0 & 0.0 & 0.0 \\
\hline Direct Personnel & 1.4 & & 0.5 & & 0.0 & & 0.0 & & 0.0 & & 0.0 & & 0.0 & & 0.0 & \\
\hline
\end{tabular}

${ }^{a}$ An 8.5\% inflation factor has been used between FY 1983 and FY 1984 and between FY 1984 and FY 1985. FY 1986-FY 1989 amounts are in constant FY 1985 dollars.

\section{GE-Materials Production}

This program primarily encompasses ORNL's uranium-233 activities; these are divided into two tasks. The first is routine operation of the uranium-233 National Repository, which supplies various experimenters in the United States with the isotope, as directed by DOE through ORO. Any unused material from scrap generated by experimental studies is also recovered. This effort is expected to remain at the current level for the foreseeable future and will be the major contribution to this program in FY 1988 and FY 1989.

The second activity is the installation and operation of a facility capable of converting $1000 \mathrm{~kg}$ of uranium (composed mainly of the fissile isotopes of uranium) from a liquid to an inert solid. Engineering design and fabrication of the processing equipment have been completed, and installation and check-out are scheduled for completion in FY 1985. Processing is expected to begin in FY 1985, and the project is expected to be completed by FY 1987.

Additional funding amounting to \$2 million in FY 1984 and \$2.5 million in FY 1985 and FY 1986 has been incorporated into the GE program budget to cover a new gyrotron development task. The 
ORNL Fusion Program will receive this funding through the ASDP to combine with the existing program funded by the Office of Fusion Energy. The application is for isotope separation for military fuel processing. All of this funding is scheduled to be subcontracted.

GE-Materials Production Program resource summary

\begin{tabular}{|c|c|c|c|c|c|c|c|c|c|c|c|c|c|c|c|c|}
\hline \multirow{2}{*}{$\begin{array}{c}(\$ \text { in Millions })^{a} \\
(\text { Personnel in FTEs) }\end{array}$} & \multicolumn{2}{|c|}{ FY 1982} & \multicolumn{2}{|c|}{ FY 1983} & \multicolumn{2}{|c|}{ FY 1984} & \multicolumn{2}{|c|}{ FY 1985} & \multicolumn{2}{|c|}{ FY 1986} & \multicolumn{2}{|c|}{ FY 1987} & \multicolumn{2}{|c|}{ FY 1988} & \multicolumn{2}{|c|}{ FY 1989} \\
\hline & BA & BO & BA & BO & BA & BO & $\mathbf{B A}$ & BO & BA & BO & BA & BO & BA & $\mathrm{BO}$ & BA & BO \\
\hline Total Operating & 5.2 & 5.8 & 5.6 & 5.2 & 9.1 & 9.4 & 10.7 & 10.1 & 6.6 & 7.0 & 3.0 & 3.1 & 2.4 & 2.4 & 2.4 & 2.4 \\
\hline Capital Equipment & 0.2 & & 0.04 & & 0.14 & & 0.14 & & 0.16 & & 0.16 & & 0.16 & & 0.16 & \\
\hline Construction & 0.0 & & 0.0 & & 0.0 & & 0.0 & & 0.0 & & 0.0 & & 0.0 & & 0.0 & \\
\hline $\begin{array}{l}\text { Total for major } \\
\text { programs }\end{array}$ & 5.4 & 5.8 & 5.6 & 5.2 & 9.2 & 9.4 & 10.8 & 10.1 & 6.8 & 7.0 & 3.2 & 3.1 & 2.6 & 2.4 & 2.6 & 2.4 \\
\hline Direct Personnel & 49.0 & & 32.5 & & 34.5 & & 36.7 & & 31.5 & & 23.0 & & 18.5 & & 18.5 & \\
\hline
\end{tabular}

${ }^{\circ}$ An $8.5 \%$ inflation factor has been used between FY 1983 and FY 1984 and between FY 1984 and FY 1985. FY 1986-FY 1989 amounts are in constant FY 1985 dollars.

\section{Assistant Secretary for Conservation and Renewable Energy (ASCE)}

ORNL's activities for ASCE encompass ten program categories covering a diversity of conservation and renewable energy topics. In general, renewable energy categories have been receiving decreasing emphasis, while conservation categories have become strongly focused on long-range generic research (see Table 8). The substantial increase in the budget for FY 1984 is due to the construction of the HTML.

Table 8. ASCE Major Program summary"

( $\$$ in Millions-BA)

\begin{tabular}{llccc}
\hline B\&R code & Major programs & FY 1983 & FY 1984 & FY 1985 \\
\hline AK & Electric Energy & 4.58 & 4.47 & 4.80 \\
& $\begin{array}{l}\text { Systems } \\
\text { AL }\end{array}$ & 1.61 & 1.28 & 1.43 \\
& $\begin{array}{l}\text { Energy Storage } \\
\text { Systems }\end{array}$ & & & \\
AM & Geothermal & 0.03 & 0.59 & 0.65 \\
CE & Hydropower & 0.60 & 0.0 & 0.0 \\
EB & Solar Energy & 3.81 & 5.24 & 5.26 \\
EC & Buildings and & 10.52 & 10.36 & 9.26 \\
ED & Community Systems & & & \\
EE & Industrial & 0.55 & 1.88 & 2.46 \\
EF & Transportation & 2.66 & 14.71 & 15.75 \\
EG & State/Local & 0.60 & 0.86 & 0.50 \\
Total & Multisector & 3.50 & 3.24 & 3.30 \\
Percent of total & 28.46 & 42.63 & 43.41 \\
Laboratory funding-BA & 8.0 & 10.7 & 9.2 \\
\hline
\end{tabular}

${ }^{a}$ Figures include operating BA, capital equipment, and funded/ budgeted construction. 


\section{AK-Electric Energy Systems}

Most of the activities in the AK program deal with power systems technology. The purpose is to investigate new concepts and develop future technology for the electric utility industry. These technologies offer opportunities to improve the efficiency of the electric energy system both economically and through resource conservation. The activities are currently organized into seven major task areas: gaseous dielectrics, automation and control, new technology integration, electric power delivery, materials, electromagnetic pulse, and human-risk analysis. Significant accomplishments during the year were the development of improved metal oxide varistors and the measurement of peak temperature along an optical fiber for detection of transformer hot spots. In the future, the tasks related to electric power delivery and technology integration will be deemphasized, while the electromagnetic pulse and risk analysis work will increase.

AK - Electric Energy Systems Program resource summary

\begin{tabular}{|c|c|c|c|c|c|c|c|c|c|c|c|c|c|c|c|c|}
\hline \multirow{2}{*}{$\begin{array}{c}(\$ \text { in Millions })^{a} \\
\text { (Personnel in FTEs) }\end{array}$} & \multicolumn{2}{|c|}{ FY 1982} & \multicolumn{2}{|c|}{ FY 1983} & \multicolumn{2}{|c|}{ FY 1984} & \multicolumn{2}{|c|}{ FY 1985} & \multicolumn{2}{|c|}{ FY 1986} & \multicolumn{2}{|c|}{ FY 1987} & \multicolumn{2}{|c|}{ FY 1988} & \multicolumn{2}{|c|}{ FY 1989} \\
\hline & BA & BO & BA & BO & BA & BO & $\mathbf{B A}$ & BO & $\mathbf{B A}$ & BO & BA & $\mathrm{BO}$ & BA & BO & BA & BO \\
\hline Total Operating & 3.8 & 5.9 & 3.2 & 5.3 & 4.5 & 7.5 & 4.8 & 5.3 & 5.0 & 5.0 & 5.0 & 5.0 & 5.0 & 5.0 & 5.0 & 5.0 \\
\hline Capital Equipment & 0.1 & & 1.4 & & 0.0 & & 0.9 & & 0.0 & & 0.0 & & 0.0 & & 0.0 & \\
\hline Construction & 0.0 & & 0.0 & & 0.0 & & 0.0 & & 0.0 & & 0.0 & & 0.0 & & 0.0 & \\
\hline $\begin{array}{l}\text { Total for major } \\
\text { programs }\end{array}$ & 3.9 & 5.9 & 4.6 & 5.3 & 4.5 & 7.5 & 4.8 & 5.3 & 5.0 & 5.0 & 5.0 & 5.0 & 5.0 & 5.0 & 5.0 & 5.0 \\
\hline Direct Personnel & 15.6 & & 14.4 & & 18.7 & & 18.3 & & 17.2 & & 17.2 & & 17.2 & & 17.2 & \\
\hline
\end{tabular}

${ }^{a}$ An $8.5 \%$ inflation factor has been used between FY 1983 and FY 1984 and between FY 1984 and FY 1985.

FY 1986 FY 1989 amounts are in constant FY 1985 dollars.

\section{AL-Energy Storage Systems}

In the area of thermal energy storage, ORNL has been assigned responsibility for building heating and cooling applications and for industrial applications. Program objectives have been identified as follows: to develop (1) concepts allowing heat pump thermal storage, (2) allowing significantly increased reuse of high-temperature industrial reject heat, (3) concepts suitable for passive solar heat storage and (4) a data base for new heat storage materials and processes.

AL-Energy Storage Systems Program resource summary

\begin{tabular}{|c|c|c|c|c|c|c|c|c|c|c|c|c|c|c|c|c|}
\hline \multirow{2}{*}{$\begin{array}{c}(\$ \text { in Millions })^{a} \\
(\text { Personnel in FTEs) }\end{array}$} & \multicolumn{2}{|c|}{ FY 1982} & \multicolumn{2}{|c|}{ FY 1983} & \multicolumn{2}{|c|}{ FY 1984} & \multicolumn{2}{|c|}{ FY 1985} & \multicolumn{2}{|c|}{ FY 1986} & \multicolumn{2}{|c|}{ FY 1987} & \multicolumn{2}{|c|}{ FY 1988} & \multicolumn{2}{|c|}{ FY 1989} \\
\hline & BA & BO & BA & BO & BA & BO & BA & BO & BA & BO & BA & $\mathrm{BO}$ & BA & $\mathrm{BO}$ & BA & BO \\
\hline Total Operating & 1.5 & 3.4 & 1.6 & 2.4 & 1.2 & 1.4 & 1.4 & 1.6 & 1.6 & 1.6 & 1.6 & 1.6 & 1.6 & 1.6 & 1.6 & 1.6 \\
\hline Capital Equipment & 0.10 & & 0.0 & & 0.08 & & 0.03 & & 0.03 & & 0.03 & & 0.03 & & 0.03 & \\
\hline Construction & 0.0 & & 0.0 & & 0.0 & & 0.0 & & 0.0 & & 0.0 & & 0.0 & & 0.0 & \\
\hline $\begin{array}{l}\text { Total for major } \\
\text { programs }\end{array}$ & 1.6 & 3.4 & 1.6 & 2.4 & 1.3 & 1.4 & 1.4 & 1.6 & 1.6 & 1.6 & 1.6 & 1.6 & 1.6 & 1.6 & 1.6 & 1.6 \\
\hline Direct Personnel & 10.8 & & 7.4 & & 4.2 & & 5.2 & & 5.0 & & 5.0 & & 5.0 & & 5.0 & \\
\hline
\end{tabular}

${ }^{a}$ An $8.5 \%$ inflation factor has been used between FY 1983 and FY 1984 and between FY 1984 and FY 1985. FY 1986-FY 1989 amounts are in constant FY 1985 dollars. 


\section{AM-Geothermal}

Our contributions to geothermal research are in two areas. First, we investigate experimentally and analytically the potential for enhanced heat transfer to improve the performance of systems operating with relatively low temperature differences. Second, we examine proposed installations to ensure that the associated environmental impacts are within acceptable limits. Geothermal program work is expected to remain stable at a level of 3.7 FTEs.

AM-Geothermal Program resource summary

\begin{tabular}{|c|c|c|c|c|c|c|c|c|c|c|c|c|c|c|c|c|}
\hline \multirow{2}{*}{$\begin{array}{c}\text { ( } \$ \text { in Millions })^{a} \\
\text { (Personnel in FTEs) }\end{array}$} & \multicolumn{2}{|c|}{ FY 1982} & \multicolumn{2}{|c|}{ FY 1983} & \multicolumn{2}{|c|}{ FY 1984} & \multicolumn{2}{|c|}{ FY 1985} & \multicolumn{2}{|c|}{ FY 1986} & \multicolumn{2}{|c|}{ FY 1987} & \multicolumn{2}{|c|}{ FY 1988} & \multicolumn{2}{|c|}{ FY 1989} \\
\hline & BA & BO & BA & BO & BA & BO & BA & BO & BA & BO & $\mathrm{BA}$ & BO & BA & BO & $\mathbf{B A}$ & BO \\
\hline Total Operating & 0.21 & 0.43 & 0.03 & 0.25 & 0.59 & 0.57 & 0.65 & 0.62 & 0.63 & 0.63 & 0.63 & 0.63 & 0.63 & 0.63 & 0.63 & 0.63 \\
\hline Capital Equipment & 0.0 & & 0.0 & & 0.0 & & 0.0 & & 0.0 & & 0.0 & & 0.0 & & 0 & \\
\hline Construction & 0.0 & & 0.0 & & 0.0 & & 0.0 & & 0.0 & & 0.0 & & 0.0 & & 0.0 & \\
\hline $\begin{array}{l}\text { Total for major } \\
\text { programs }\end{array}$ & 0.21 & 0.43 & 0.03 & 0.25 & 0.59 & 0.57 & 0.65 & 0.62 & 0.63 & 0.63 & 0.63 & 0.63 & 0.63 & 0.63 & 0.63 & 0.63 \\
\hline Direct Personnel & 3.7 & & 1.9 & & 3.7 & & 3.7 & & 3.7 & & 3.7 & & 3.7 & & 3.7 & \\
\hline
\end{tabular}

${ }^{\circ}$ An $8.5 \%$ inflation factor has been used between FY 1983 and FY 1984 and between FY 1984 and FY 1985. FY 1986-FY 1989 amounts are in constant FY 1985 dollars.

\section{CE-Hydropower}

The purpose of our work in the CE program is to provide technical assistance to DOE for resolution of specific environmental issues associated with small hydropower development. The focus of the FY 1984 work will be to continue our instream flow research and turbine-related fish mortality studies. At this time, FY 1985 support remains uncertain.

\section{CE-Hydropower Program resource summary}

\begin{tabular}{|c|c|c|c|c|c|c|c|c|c|c|c|c|c|c|c|c|}
\hline \multirow{2}{*}{$\begin{array}{c}(\$ \text { in Millions })^{a} \\
(\text { Personnel in FTEs) }\end{array}$} & \multicolumn{2}{|c|}{ FY 1982} & \multicolumn{2}{|c|}{ FY 1983} & \multicolumn{2}{|c|}{ FY 1984} & \multicolumn{2}{|c|}{ FY 1985} & \multicolumn{2}{|c|}{ FY 1986} & \multicolumn{2}{|c|}{ FY 1987} & \multicolumn{2}{|c|}{ FY 1988} & \multicolumn{2}{|c|}{ FY 1989} \\
\hline & BA & BO & BA & BO & $\mathbf{B A}$ & BO & $\mathbf{B A}$ & BO & BA & BO & BA & BO & BA & $\mathrm{BO}$ & BA & BO \\
\hline Total Operating & 0.40 & 0.36 & 0.6 & 0.5 & 0.0 & 0.3 & 0.0 & 0.0 & 0.0 & 0.0 & 0.0 & 0.0 & 0.0 & 0.0 & 0.0 & 0.0 \\
\hline Capital Equipment & 0.0 & & 0.0 & & 0.0 & & 0.0 & & 0.0 & & 0.0 & & 0.0 & & 0.0 & \\
\hline Construction & 0.0 & & 0.0 & & 0.0 & & 0.0 & & 0.0 & & 0.0 & & 0.0 & & 0.0 & \\
\hline $\begin{array}{l}\text { Total for major } \\
\text { programs }\end{array}$ & 0.40 & 0.36 & 0.6 & 0.5 & 0.0 & 0.3 & 0.0 & 0.0 & 0.0 & 0.0 & 0.0 & 0.0 & 0.0 & 0.0 & 0.0 & 0.0 \\
\hline Direct Personnel & 3.3 & & 4.5 & & 2.5 & & 0.0 & & 0.0 & & 0.0 & & 0.0 & & 0.0 & \\
\hline
\end{tabular}

${ }^{a}$ An $8.5 \%$ inflation factor has been used between FY 1983 and FY 1984 and between FY 1984 and FY 1985. FY 1986-FY 1989 amounts are in constant FY 1985 dollars.

\section{$E B-S o l a r$ Energy}

The principal ORNL activity in solar energy is the technical management of the Short Rotation Woody Crops Program, which consists of long-term research on the production of woody and herbaceous biomass. Research concentrates on species screening and genetic studies, stand establishment and management, and economic studies. The program also includes regional resource 
evaluations, nutrient utilization studies, the evaluation of environmental effects of whole-tree harvesting, and participation in international cooperative agreements. Much of the work is subcontracted. After FY 1985, the Short Rotation Woody Crops Program will be evaluated vis-à-vis the respective roles of government and industry.

ORNL participation in other solar programs is limited to tasks in which specific expertise is available, including technical assistance on photovoltaic projects, analysis of wind energy systems, and environmental analysis for alcohol fuels projects. Both the Solar Applications for Buildings (EB01) and the Alcohol Financial Assistance (EB11) programs are expected to be phased out after FY 1984 and FY 1983, respectively. The Solar Applications for Industry (EB02) component is projected to continue as the major focus of the program throughout the planning cycle along with a small but constant effort in Solar Applications for Power (EB03).

EB-Solar Energy Program resource summary

\begin{tabular}{|c|c|c|c|c|c|c|c|c|c|c|c|c|c|c|c|c|}
\hline \multirow{2}{*}{$\begin{array}{c}(\$ \text { in Millions })^{a} \\
(\text { Personnel in FTEs) }\end{array}$} & \multicolumn{2}{|c|}{ FY 1982} & \multicolumn{2}{|c|}{ FY 1983} & \multicolumn{2}{|c|}{ FY 1984} & \multicolumn{2}{|c|}{ FY 1985} & \multicolumn{2}{|c|}{ FY 1986} & \multicolumn{2}{|c|}{ FY 1987} & \multicolumn{2}{|c|}{ FY 1988} & \multicolumn{2}{|c|}{ FY 1989} \\
\hline & BA & BO & BA & BO & BA & $\mathrm{BO}$ & BA & $\mathrm{BO}$ & BA & BO & BA & $\mathrm{BO}$ & BA & BO & BA & BO \\
\hline Total Operating & 5.0 & 5.9 & 3.8 & 3.9 & 5.2 & 4.7 & 5.2 & 5.2 & 5.2 & 5.2 & 5.2 & 5.2 & 5.2 & 5.2 & 5.2 & 5.2 \\
\hline Capital Equipment & 0.2 & & 0.01 & & 0.05 & & 0.05 & & 0.05 & & 0.05 & & 0.05 & 0.05 & 0.05 & \\
\hline Construction & 0.0 & & 0.0 & & 0.0 & & 0.0 & & 0.0 & & 0.0 & & 0.0 & & 0.0 & \\
\hline $\begin{array}{l}\text { Total for major } \\
\text { programs }\end{array}$ & 5.2 & 5.9 & 3.8 & 3.9 & 5.2 & 4.7 & 5.2 & 5.2 & 5.2 & 5.2 & 5.2 & 5.2 & 5.2 & 5.2 & 5.2 & 5.2 \\
\hline Direct Personnel & 21.4 & & 8.3 & & 7.9 & & 6.0 & & 6.0 & & 6.0 & & 6.0 & & 6.0 & \\
\hline
\end{tabular}

${ }^{a}$ An $8.5 \%$ inflation factor has been used between FY 1983 and FY 1984 and between FY 1984 and FY 1985. FY 1986-FY 1989 amounts are in constant FY 1985 dollars.

\section{EC-Buildings and Community Systems}

ORNL has been assigned technical management responsibility for three programs in the buildings area: Building Thermal Envelope Systems and Insulating Materials (BTESIM), Building Equipment Research (BER), and Residential Conservation Service (RCS). The BTESIM Program was initiated in response to the need of the insulation and building communities for relevant technical information on the thermal performance of building-envelope systems and in recognition of the impact that improved thermal performance of buildings would have on energy conservation. A National Program Plan, which was developed jointly by DOE, ORNL, and National Bureau of Standards (NBS) with the assistance of industry, forms the basis for selection of research projects. The BER Program seeks to conserve energy by developing improved heating and cooling systems and appliances. BER activities include analytical studies, development of analytical tools, and laboratory and field experiments. The major program areas are vapor-compression systems, nonazeotropic refrigerant mixtures, ground-coupled heat pumps, absorption and Stirling cycle systems, internal-combustion (IC)-engine-driven heat pumps, fossil-fueled water heaters, and advanced insulation. The RCS program consists of providing DOE with the technical management functions for implementation of the congressionally mandated building-retrofit program. It is expected that ORNL participation in R\&D in this program will end in FY 1984. Other activities in the Buildings and Community Systems area include development of the anaerobic packed-bed bioreactor (ANFLOW) process and projects in energy-use analysis. 
EC-Buildings and Community Systems Program resource summary

\begin{tabular}{|c|c|c|c|c|c|c|c|c|c|c|c|c|c|c|c|c|}
\hline \multirow{2}{*}{$\begin{array}{c}(S \text { in Millions) } \\
\text { (Personnel in FTEs) }^{a}\end{array}$} & \multicolumn{2}{|c|}{ FY 1982} & \multicolumn{2}{|c|}{ FY 1983} & \multicolumn{2}{|c|}{ FY 1984} & \multicolumn{2}{|c|}{ FY 1985} & \multicolumn{2}{|c|}{ FY 1986} & \multicolumn{2}{|c|}{ FY 1987} & \multicolumn{2}{|c|}{ FY 1988} & \multicolumn{2}{|c|}{ FY 1989} \\
\hline & BA & BO & BA & BO & $\mathbf{B A}$ & BO & BA & BO & BA & BO & $\mathrm{BA}$ & $\mathrm{BO}$ & BA & $\mathrm{BO}$ & BA & BO \\
\hline Total Operating & 13.0 & 13.5 & 10.5 & 10.8 & 9.5 & 10.1 & 8.8 & 8.9 & 9.0 & 9.3 & 9.0 & 9.0 & 9.0 & 9.0 & 9.0 & 9.0 \\
\hline Capital Equipment & 0.05 & & 0.0 & & 0.86 & & 0.46 & & 0.10 & & 0.10 & & 0.10 & & 0.10 & \\
\hline Construction & 0.0 & & 0.0 & & 0.0 & & 0.0 & & 0.0 & & 0.0 & & 0.0 & & 0.0 & \\
\hline $\begin{array}{l}\text { Total for major } \\
\text { programs }\end{array}$ & 13.0 & 13.5 & 10.5 & 10.8 & 10.4 & 10.1 & 9.3 & 8.9 & 9.1 & 9.3 & 9.1 & 9.0 & 9.1 & 9.0 & 9.1 & 9.0 \\
\hline Direct Personnel & 44.4 & & 43.0 & & 45.4 & & 36.5 & & 23.0 & & 21.0 & & 21.0 & & 21.0 & \\
\hline
\end{tabular}

An 8.5\% inflation factor has been used between FY 1983 and FY 1984 and between FY 1984 and FY 1985. FY 1986-FY 1989 amounts are in constant FY 1985 dollars.

\section{ED-Industrial}

ORNL is currently responsible for two projects under Industrial Energy Conservation. The first of these, Materials for Waste Heat Utilization, provides materials technology support to the Waste Energy Utilization Branch and its contractors in support of recuperator development and in developing improved ceramic technologies. In the second project, Chemical Heat Pumps, the objective is to develop chemical heat-pump technology for recovering industrial and process waste heat. In this project, an innovative absorption heat pump for industrial waste heat recovery has been designed and tested. Activities under the ED02 activity code (Industrial Process Efficiency) are being phased out, while ED01 (Waste Energy Reduction) activities project an increase to an annual level of $\$ 2.4$ million, which is to be maintained throughout the planning cycle.

ED-Industrial Program resource summary

\begin{tabular}{|c|c|c|c|c|c|c|c|c|c|c|c|c|c|c|c|c|}
\hline \multirow{2}{*}{$\begin{array}{c}(\$ \text { in Millions })^{a} \\
\text { (Personnel in FTEs) }\end{array}$} & \multicolumn{2}{|c|}{ FY 1982} & \multicolumn{2}{|c|}{ FY 1983} & \multicolumn{2}{|c|}{ FY 1984} & \multicolumn{2}{|c|}{ FY 1985} & \multicolumn{2}{|c|}{ FY 1986} & \multicolumn{2}{|c|}{ FY 1987} & \multicolumn{2}{|c|}{ FY 1988} & \multicolumn{2}{|c|}{ FY 1989} \\
\hline & BA & BO & BA & $\mathrm{BO}$ & BA & BO & BA & $\mathrm{BO}$ & BA & BO & BA & BO & BA & BO & BA & BO \\
\hline Total Operating & 2.1 & 0.8 & 0.6 & 1.4 & 1.8 & 2.0 & 2.4 & 2.4 & 2.4 & 2.4 & 2.4 & 2.4 & 2.4 & 2.4 & 2.4 & 2.4 \\
\hline Capital Equipment & 0.0 & & 0.0 & & 0.08 & & 0.06 & & 0.06 & & 0.06 & & 0.06 & & 0.06 & \\
\hline Construction & 0.0 & & 0.0 & & 0.0 & & 0.0 & & 0.0 & & 0.0 & & 0.0 & & 0.0 & \\
\hline $\begin{array}{l}\text { Total for major } \\
\text { programs }\end{array}$ & 2.1 & 0.8 & 0.6 & 1.4 & 1.9 & 2.0 & 2.5 & 2.4 & 2.5 & 2.4 & 2.5 & 2.4 & 2.5 & 2.4 & 2.5 & 2.4 \\
\hline Direct Personnel & 4.6 & & 9.0 & & 11.5 & & 10.0 & & 10.0 & & 10.0 & & 10.0 & & 10.0 & \\
\hline
\end{tabular}

\section{EE-Transportation}

Programs for the Office of Vehicles and Engines Research and Development include the development of ceramic technology for advanced heat engines and the analysis of transportation data related to energy use. A principal activity of the heat-engine ceramics program has been the preparation of a multiyear program plan. Implementation of the plan will involve five principal program elements: program management and coordination, materials and processing, material design methodology, data base/life prediction, and technology transfer.

Funding for construction of the HTML is currently budgeted under this program. It is anticipated that extensive use of the new laboratory will also be made under the KC02 (Materials Sciences) Program funded by OER. 
EE-Transportation Program resource summary

\begin{tabular}{|c|c|c|c|c|c|c|c|c|c|c|c|c|c|c|c|c|}
\hline \multirow{2}{*}{$\begin{array}{c}(\$ \text { in Millions })^{a} \\
\text { (Personnel in FTEs) }\end{array}$} & \multicolumn{2}{|c|}{ FY 1982} & \multicolumn{2}{|c|}{ FY 1983} & \multicolumn{2}{|c|}{ FY 1984} & \multicolumn{2}{|c|}{ FY 1985} & \multicolumn{2}{|c|}{ FY 1986} & \multicolumn{2}{|c|}{ FY 1987} & \multicolumn{2}{|c|}{ FY 1988} & \multicolumn{2}{|c|}{ FY 1989} \\
\hline & BA & BO & BA & BO & BA & BO & BA & BO & $\mathrm{BA}$ & BO & $\mathrm{BA}$ & BO & BA & BO & BA & $\mathrm{BO}$ \\
\hline Total Operating & 0.6 & 0.3 & 2.7 & 1.1 & 5.5 & 3.9 & 6.6 & 6.3 & 8.0 & 8.0 & 08.0 & 8.0 & 8.0 & 8.0 & 8.0 & 8.0 \\
\hline Capital Equipment & 0.0 & & 0.0 & & 0.2 & & 0.2 & & 0.2 & & 00.2 & & 0.2 & & 0.2 & \\
\hline Construction & $0.0^{\circ}$ & & 0.0 & & 9.0 & & 9.0 & & 2.6 & & 0.0 & & 0.0 & & 0.0 & \\
\hline $\begin{array}{l}\text { Total for major } \\
\text { programs }\end{array}$ & 0.6 & 0.3 & 2.7 & 1.1 & 14.7 & 3.9 & 15.8 & 6.3 & 26.5 & 8.0 & 8.2 & 8.0 & 8.2 & 8.0 & 8.2 & 8.0 \\
\hline Direct Personnel & 2.7 & & 11.1 & & 14.2 & & 15.1 & & 18.0 & & 18.0 & & 18.0 & & 18.0 & \\
\hline
\end{tabular}

EE-Budgeted construction summary

\begin{tabular}{lcccccccc}
\hline (\$ in Millions) & FY 1983 & FY 1984 & FY 1985 & FY 1986 & FY 1987 & FY 1988 & FY 1989 & TEC \\
\hline $\begin{array}{c}\text { High Temperature } \\
\text { Materials Laboratory }\end{array}$ & 9.0 & 9.0 & 2.6 & & & & 20.6 \\
\hline
\end{tabular}

\section{EF-State/Local Programs}

ORNL assignments in State/Local Programs have been to assist DOE in the evaluation of the effectiveness of several of the programs. These have included State Energy Conservation programs and the Schools and Hospitals Program. Work projected for the future includes evaluations of the Weatherization Program and continuing assistance to DOE in conducting cross-program evaluations.

EF-State/Local Programs Program resource summary

\begin{tabular}{|c|c|c|c|c|c|c|c|c|c|c|c|c|c|c|c|c|}
\hline \multirow{2}{*}{$\begin{array}{c}(\$ \text { in Millions) } \\
\text { (Personnel in FTEs) }\end{array}$} & \multicolumn{2}{|c|}{ FY 1982} & \multicolumn{2}{|c|}{ FY 1983} & \multicolumn{2}{|c|}{ FY 1984} & \multicolumn{2}{|c|}{ FY 1985} & \multicolumn{2}{|c|}{ FY 1986} & \multicolumn{2}{|c|}{ FY 1987} & \multicolumn{2}{|c|}{ FY 1988} & \multicolumn{2}{|c|}{ FY 1989} \\
\hline & BA & BO & BA & BO & BA & BO & BA & BO & BA & BO & BA & BO & BA & BO & BA & BO \\
\hline & & 0.9 & & 0.5 & & 0.8 & 0.5 & 0.4 & 0.3 & 0.3 & 0.3 & 0.3 & 0.3 & 0.3 & 0.3 & 0.3 \\
\hline Capit & 0.0 & & 0.0 & & 0.0 & & 0.0 & & 0.0 & & 0.0 & & 0.0 & & 0.0 & \\
\hline Construction & 0.0 & & 0.0 & & 0.0 & & 0.0 & & 0.0 & & 0.0 & & 0.0 & & 0.0 & \\
\hline $\begin{array}{l}\text { Total for major } \\
\text { programs }\end{array}$ & 0.4 & 0.9 & 0.6 & 0.5 & 0.9 & 0.8 & 0.5 & 0.4 & 0.3 & 0.3 & 0.3 & 0.3 & 0.3 & 0.3 & 0.3 & 0.3 \\
\hline Direct Personnel & 3.7 & & 4.3 & & 6.0 & & 4.0 & & 3.0 & & 3.0 & & 3.0 & & 3.0 & \\
\hline
\end{tabular}

${ }^{a}$ An $8.5 \%$ inflation factor has been used between FY 1983 and FY 1984 and between FY 1984 and FY 1985. FY 1986-FY 1989 amounts are in constant FY 1985 dollars.

\section{EG-Multisector}

ORNL has been assigned technical management responsibility for the Materials Project and the Tribology Project - both in the area of Energy Conversion and Utilization Technology. Under the Materials Project, research is being conducted on high-temperature materials, lightweight materials, and materials properties modeling. Accomplishments in this project include the recovery of 
automobile scrap materials for use as binder fibers in plastic molding and contributions to the development of a ductile form of the intermetallic compound, $\mathrm{Ni}_{3} \mathrm{Al}$. Under the Tribology Project, the work elements are mechanisms and design. Both projects consist of exploratory and applied research efforts that are often conducted by experts in universities and industry. An additional project within the Multisector Program is the evaluation of results obtained through the Energy Related Inventions Program. Only the EG05 (Energy Conversion Technology) Program component is expected to maintain a major level of activity throughout the planning cycle.

EG-Multisector Program resource summary

\begin{tabular}{|c|c|c|c|c|c|c|c|c|c|c|c|c|c|c|c|c|}
\hline \multirow{2}{*}{$\begin{array}{c}(\$ \text { in Millions })^{a} \\
\text { (Personnel in FTEs) }\end{array}$} & \multicolumn{2}{|c|}{ FY 1982} & \multicolumn{2}{|c|}{ FY 1983} & \multicolumn{2}{|c|}{ FY 1984} & \multicolumn{2}{|c|}{ FY 1985} & \multicolumn{2}{|c|}{ FY 1986} & \multicolumn{2}{|c|}{ FY 1987} & \multicolumn{2}{|c|}{ FY 1988} & \multicolumn{2}{|c|}{ FY 1989} \\
\hline & BA & BO & BA & BO & BA & BO & BA & BO & BA & BO & BA & BO & BA & BO & $\mathbf{B A}$ & BO \\
\hline Total Oper & 1.1 & 0.9 & 3.5 & 2.0 & 2.9 & 2.9 & 2. & 2.8 & 2. & 2.7 & & 2.7 & 2. & 2.7 & 2.7 & 2.7 \\
\hline Capital Equipment & 0.14 & & 0.0 & & 0.3 & & 0.6 & & 0.0 & & 0.0 & & 0.0 & & 0.0 & \\
\hline Construction & 0.0 & & 0.0 & & 0.0 & & 0.0 & & 0.0 & & 0.0 & & 0.0 & & 0.0 & \\
\hline $\begin{array}{l}\text { Total for major } \\
\text { programs }\end{array}$ & 1.2 & 0.9 & 3.5 & 2.0 & 3.2 & 2.9 & 3.3 & 2.8 & 2.7 & 2.7 & 2.7 & 2.7 & 2.7 & 2.7 & 2.7 & 2.7 \\
\hline Direct Personnel & 4.4 & & 9.1 & & 12.5 & & 10.4 & & 10.0 & & 10.0 & & 10.0 & & 10.0 & \\
\hline
\end{tabular}

${ }^{a}$ An $8.5 \%$ inflation factor has been used between FY 1983 and FY 1984 and between FY 1984 and FY 1985. FY 1986-FY 1989 amounts are in constant FY 1985 dollars.

\section{Assistant Secretary for Fossil Energy (ASFE)}

ORNL's programs for the ASFE cover three major areas-coal, petroleum, and alternate fuels. The Coal Program (AA) is, however, the primary focus of the Laboratory's fossil energy activities (see Table 9). The coal budget is anticipated to increase substantially with the addition of the Fossil Energy Technology Environmental Program.

Table 9. ASFE Major Program summary"

( $\$$ in Millions-BA)

\begin{tabular}{lllcc}
\hline B\&R code & Major programs & FY 1983 & FY 1984 & FY 1985 \\
\hline AA & Coal & 8.97 & 10.14 & 16.44 \\
AB & Gas & 0.1 & 0.0 & 0.0 \\
AC & Petroleum & 0.005 & 0.0 & 0.0 \\
CH & Alternate Fuels & 0.06 & 0.15 & 0.62 \\
$\quad$ Total & Production & & & \\
Percent of total & & 9.14 & 10.29 & 17.06 \\
$\quad$ Laboratory funding-BA & & 2.6 & 2.6 & 3.6 \\
\hline
\end{tabular}

${ }^{a}$ Figures include operating BA, capital equipment, and funded/budgeted construction.

\section{$A A-C o a l$}

ORNL's work in the Coal Program involves several areas of activity. In the Control Technology and Coal Preparation subprogram (AA05), current work is being closed out, but a small effort 
(about 2 FTEs) is projected to resume in analysis and evaluation of coal preparation technology. The Advanced Research and Technology Development (AR\&TD) effort (AA15) is a wellestablished activity covering research, analysis, and evaluation of coal-conversion technologies; strategic planning support; and management (with ORO) of the National Fossil Energy Materials Program. This area also provides some support for environmental and effluent control technology tasks. Overall support in AA15 is projected to increase somewhat (to about 25 FTEs) as additional process technology research is carried out to help maintain a balanced effort at ORNL and an appropriate in-house expertise to support analysis tasks.

Work in the Liquefaction subprogram (AA25) currently involves primarily research on the bioactivity of coal liquids, with some R\&D related to process technology and components. In addition, the FY 1982-FY 1987 ORNL Institutional Plan contained a new initiative titled "Environmental Control Technology." This initiative has been pursued by ORNL in subsequent years. Funding is now beginning to develop in this area, which currently bears the title, "Fossil Energy Technology Environmental Program." A substantial increase to about 34 FTEs is projected for this area by FY 1986. Some relatively minor support for materials R\&D in liquefaction is also projected in this area.

In the Combustion Systems subprogram (AA35), the current effort is a closeout of analytic studies of pressurized and atmospheric fluidized-bed combustion (FBC) systems. Currently, no additional work is projected for this area. The small effort of the Heat Engines and Heat Recovery subprogram (AA55) is projected to end FY 1984. Work on the Surface Coal Gasification subprogram (AA85) currently involves components technology and materials technology. Only the materials effort is continuing in FY 1984, and a generally stable support level (of about 6 FTEs) is anticipated for that work.

\begin{tabular}{|c|c|c|c|c|c|c|c|c|c|c|c|c|c|c|c|c|}
\hline \multirow{3}{*}{$\begin{array}{c}(\$ \text { in Millions })^{a} \\
\text { (Personnel in FTEs) }\end{array}$} & \multicolumn{12}{|c|}{ AA-Coal Program resource summary } & & & & \\
\hline & \multicolumn{2}{|c|}{ FY 1982} & \multicolumn{2}{|c|}{ FY 1983} & \multicolumn{2}{|c|}{ FY 1984} & \multicolumn{2}{|c|}{ FY 1985} & \multicolumn{2}{|c|}{ FY 1986} & \multicolumn{2}{|c|}{ FY 1987} & \multicolumn{2}{|c|}{ FY 1988} & \multicolumn{2}{|c|}{ FY 1989} \\
\hline & BA & BO & BA & BO & $\mathrm{BA}$ & BO & $\mathrm{BA}$ & BO & $\mathrm{BA}$ & BO & BA & BO & BA & $\mathrm{BO}$ & $\mathrm{BA}$ & $\mathrm{BO}$ \\
\hline Total Operating & 11.4 & 13.3 & 8.9 & 10.1 & 9.6 & 10.4 & 15.9 & 14.7 & 15.9 & 15.9 & 15.9 & 15.9 & 15.9 & 15.9 & 15.9 & 15.9 \\
\hline Capital Equipment & 0.2 & & 0.1 & & 0.5 & & 0.5 & & 0.7 & & 0.7 & & 0.7 & & 0.7 & \\
\hline Construction & 0.0 & & 0.0 & & 0.0 & & 0.0 & & 0.0 & & 0.0 & & 0.0 & & 0.0 & \\
\hline $\begin{array}{l}\text { Total for major } \\
\text { programs }\end{array}$ & 11.6 & 13.3 & 9.0 & 10.1 & 10.1 & 10.4 & 16.4 & 14.7 & 16.6 & 15.9 & 16.6 & 15.9 & 16.6 & 15.9 & 16.6 & 15.9 \\
\hline Direct Personnel & 72.7 & & 51.0 & & 45.7 & & 60.8 & & 66.2 & & 66.2 & & 66.2 & & 66.2 & \\
\hline
\end{tabular}

\section{$A B-G a s$}

Minor funding was provided in this area in FY 1983 for a task to be performed in FY 1984. This task is related to economic and technical evaluations of processes. Further funding in this area is not currently anticipated. 
AB-Gas Program resource summary

\begin{tabular}{|c|c|c|c|c|c|c|c|c|c|c|c|c|c|c|}
\hline \multirow{2}{*}{$\begin{array}{c}(\$ \text { in Millions })^{a} \\
(\text { Personnel in FTEs) }\end{array}$} & \multicolumn{2}{|c|}{ FY 1983} & \multicolumn{2}{|c|}{ FY 1984} & \multicolumn{2}{|c|}{ FY 1985} & \multicolumn{2}{|c|}{ FY 1986} & \multicolumn{2}{|c|}{ FY 1987} & \multicolumn{2}{|c|}{ FY 1988} & \multicolumn{2}{|c|}{ FY 1989} \\
\hline & BA & BO & BA & BO & BA & BO & BA & BO & BA & BO & BA & BO & BA & BO \\
\hline & & 0.1 & & & & & & & & 0.0 & & & & \\
\hline Capital Equipment & 0.0 & & 0.0 & & 0.0 & & 0.0 & & 0.0 & & 0.0 & & 0.0 & \\
\hline Construction & 0.0 & & 0.0 & & 0.0 & & 0.0 & & 0.0 & & 0.0 & & 0.0 & \\
\hline $\begin{array}{l}\text { Total for major } \\
\text { programs }\end{array}$ & 0.0 & 0.0 & 0.0 & 0.1 & 0.0 & 0.0 & 0.0 & 0.0 & 0.0 & 0.0 & 0.0 & 0.0 & 0.0 & 0.0 \\
\hline Direct Personnel & 0.0 & & 0.0 & & 0.0 & & 0.0 & & 0.0 & & 0.0 & & 0.0 & \\
\hline
\end{tabular}

${ }^{a}$ An 8.5\% inflation factor has been used between FY 1983 and FY 1984 and between FY 1984 and FY 1985. FY 1986-FY 1989 amounts are in constant FY 1985 dollars.

\section{AC-Petroleum}

This work involved research on amphiphilic compounds for use in the micellar flood approach to enhanced oil recovery. The FY 1983 effort represented a closeout of prior activity.

AC-Petroleum Program resource summary

\begin{tabular}{|c|c|c|c|c|c|c|c|c|c|c|c|c|c|c|c|c|}
\hline \multirow{2}{*}{$\begin{array}{c}(\$ \text { in Millions })^{a} \\
\text { (Personnel in FTEs) }\end{array}$} & \multicolumn{2}{|c|}{ FY 1982} & \multicolumn{2}{|c|}{ FY 1983} & \multicolumn{2}{|c|}{ FY 1984} & \multicolumn{2}{|c|}{ FY 1985} & \multicolumn{2}{|c|}{ FY 1986} & \multicolumn{2}{|c|}{ FY 1987} & \multicolumn{2}{|c|}{ FY 1988} & \multicolumn{2}{|c|}{ FY 1989} \\
\hline & BA & BO & BA & BO & BA & BO & BA & BO & BA & BO & BA & BO & BA & BO & BA & BO \\
\hline & & 0.1 & 0.0 & 0.03 & 0.0 & 0.0 & 0.0 & 0.0 & 0.0 & 0.0 & 0.0 & 0.0 & 0.0 & 0.0 & 0.0 & 0.0 \\
\hline Capital Equipment & 0.0 & & 0.0 & & 0.0 & & 0.0 & & 0.0 & & 0.0 & & 0.0 & & 0.0 & \\
\hline Construction & 0.0 & & 0.0 & & 0.0 & & 0.0 & & 0.0 & & 0.0 & & 0.0 & & 0.0 & \\
\hline $\begin{array}{l}\text { Total for major } \\
\text { programs }\end{array}$ & 0.2 & 0.1 & 0.0 & 0.03 & 0.0 & 0.0 & 0.0 & 0.0 & 0.0 & 0.0 & 0.0 & 0.0 & 0.0 & 0.0 & 0.0 & 0.0 \\
\hline Direct Personnel & 0.7 & & 0.2 & & 0.0 & & 0.0 & & 0.0 & & 0.0 & & 0.0 & & 0.0 & \\
\hline
\end{tabular}

${ }^{a}$ An $8.5 \%$ inflation factor has been used between FY 1983 and FY 1984 and between FY 1984 and FY 1985. FY 1986-FY 1989 amounts are in constant FY 1985 dollars.

\section{CH-Alternate Fuels Production}

This activity provides support to the Morgantown Energy Technology Center in mathematical modeling of coal gasification process technologies. This effort is expected to recover to a level of about 3 FTEs.

CH-Alternate Fuels Product Program resource summary

\begin{tabular}{|c|c|c|c|c|c|c|c|c|c|c|c|c|c|c|c|c|}
\hline \multirow{2}{*}{$\begin{array}{c}(\$ \text { in Millions })^{a} \\
\text { (Personnel in FTEs) }^{(2)}\end{array}$} & \multicolumn{2}{|c|}{ FY 1982} & \multicolumn{2}{|c|}{ FY 1983} & \multicolumn{2}{|c|}{ FY 1984} & \multicolumn{2}{|c|}{ FY 1985} & \multicolumn{2}{|c|}{ FY 1986} & \multicolumn{2}{|c|}{ FY 1987} & \multicolumn{2}{|c|}{ FY 1988} & \multicolumn{2}{|c|}{ FY 1989} \\
\hline & BA & BO & BA & BO & BA & BO & BA & BO & BA & BO & BA & BO & BA & BO & BA & BO \\
\hline Total Operating & 0.3 & 0.2 & 0.06 & 0.55 & 0.14 & 0.18 & 0.6 & 0.4 & 0.7 & 0.7 & 0.7 & 0.7 & 0.7 & 0.7 & 0.7 & 0.7 \\
\hline Capital Equipment & 0.0 & & 0.0 & & 0.01 & & 0.02 & & 0.02 & & 0.02 & & 0.02 & & 0.03 & \\
\hline Construction & 0.0 & & 0.0 & & 0.0 & & 0.0 & & 0.0 & & 0.0 & & 0.0 & & 0.0 & \\
\hline $\begin{array}{l}\text { Total for major } \\
\text { programs }\end{array}$ & 0.3 & 0.2 & 0.06 & 0.55 & 0.15 & 0.18 & 0.6 & 0.4 & 0.7 & 0.7 & 0.7 & 0.7 & 0.7 & 0.7 & 0.7 & 0.7 \\
\hline Direct Personnel & 0.9 & & 0.2 & & 0.7 & & 1.8 & & 3.4 & & 4.3 & & 3.4 & & 3.4 & \\
\hline
\end{tabular}




\section{Energy Information Administration (EIA)}

ORNL provides both research and management support for EIA to help meet the needs of energy policymakers. Our EIA activities are considerably reduced from previous levels, and now encompass only two program codes (TA and TB) (see Table 10).

Table 10. Energy Information Administration Major Program summarye $(\$$ in Millions-BA)

\begin{tabular}{|c|c|c|c|c|}
\hline B \& $R$ code & Major programs & FY 1983 & FY 1984 & FY 1985 \\
\hline TA & $\begin{array}{l}\text { Collection, Production } \\
\text { and Analysis }\end{array}$ & 0.50 & 1.00 & 1.80 \\
\hline TB & Program Services & 0.0 & 0.40 & 0.39 \\
\hline Total & & 0.50 & 1.40 & 2.19 \\
\hline $\begin{array}{l}\text { Percent of total } \\
\text { Laboratory funding-BA }\end{array}$ & & 0.1 & 0.4 & 0.5 \\
\hline
\end{tabular}

${ }^{a}$ Figures include operating BA, capital equipment, and funded/ budgeted construction.

\section{TA-Collection, Production, and Analysis; TB-Program Services}

In the past, ORNL's programs in support of EIA have drawn upon multidisciplinary teams from both inside and outside the Laboratory. The work has consisted of evaluation, assembly, and analysis of data and information relevant to production and use of energy in the United States. Support has been provided to each EIA office that does work in areas where the Laboratory has both interest and experience. A major accomplishment this year was the in-house review of a requirements data study, Alternate Fuels Information Review of Requirements. In the future, these programs are expected to decrease and to primarily involve analysis and assessment activities for which in-house expertise is available. Funding for a task which is being reprogrammed from ASNE to EIA is expected to begin this year, however. This work will entail doing a uranium industry viability study, and will continue through the planning cycle.

TA/TB-EIA Program resource summary

\begin{tabular}{|c|c|c|c|c|c|c|c|c|c|c|c|c|c|c|c|c|}
\hline \multirow{2}{*}{$\begin{array}{c}(\$ \text { in Millions })^{a} \\
(\text { Personnel in FTEs })\end{array}$} & \multicolumn{2}{|c|}{ FY $1982^{b}$} & \multicolumn{2}{|c|}{ FY 1983} & \multicolumn{2}{|c|}{ FY 1984} & \multicolumn{2}{|c|}{ FY 1985} & \multicolumn{2}{|c|}{ FY 1986} & \multicolumn{2}{|c|}{ FY 1987} & \multicolumn{2}{|c|}{ FY 1988} & \multicolumn{2}{|c|}{ FY 1989} \\
\hline & BA & BO & BA & BO & BA & BO & BA & BO & BA & BO & BA & BO & BA & BO & BA & BO \\
\hline Total Operating & 9.7 & 6.4 & 0.5 & 4.9 & 1.4 & 2.2 & 2.2 & 2.2 & 2.2 & 2.2 & 2.2 & 2.2 & 2.2 & 2.2 & 2.2 & 2.2 \\
\hline Capital Equipment & 0.0 & & 0.0 & & 0.0 & & 0.0 & & 0.0 & & 0.0 & & 0.0 & & 0.0 & \\
\hline Construction & 0.0 & & 0.0 & & 0.0 & & 0.0 & & 0.0 & & 0.0 & & 0.0 & & 0.0 & \\
\hline $\begin{array}{l}\text { Total for major } \\
\text { programs }\end{array}$ & 9.7 & 6.4 & 0.5 & 4.9 & 1.4 & 2.2 & 2.2 & 2.2 & 2.2 & 2.2 & 2.2 & 2.2 & 2.2 & 2.2 & 2.2 & 2.2 \\
\hline Direct Personnel & 10.8 & & 14.5 & & 9.0 & & 9.0 & & 9.0 & & 9.0 & & 9.0 & & 9.0 & \\
\hline
\end{tabular}

${ }^{\circ}$ An $8.5 \%$ inflation factor has been used between FY 1983 and FY 1984 and between FY 1984 and FY 1985.

FY 1986-FY 1989 amounts are in constant FY 1985 dollars.

${ }^{b}$ Includes all EIA B\&R codes. 


\section{Assistant Secretary for Environmental Protection, Safety, and Emergency Preparedness (ASEP)}

The ORNL programs funded by ASEP cover environmental monitoring, research, analysis, and emergency preparedness support (Table 11). In the past, the largest component was the RASCA Program; however, the responsibility for RASCA will be transferred to the Assistant Secretary for Nuclear Energy for FY 1984.

Table 11. ASEP Major Program summary ( $\$$ in Millions-BA)

\begin{tabular}{|c|c|c|c|c|}
\hline B\&R code & Major programs & FY 1983 & FY 1984 & FY 1985 \\
\hline HA01 & $\begin{array}{l}\text { Environment, Safety, } \\
\text { and Health }\end{array}$ & 3.61 & 2.05 & 2.57 \\
\hline UB02 & $\begin{array}{l}\text { Power Supply and } \\
\text { Reliability }\end{array}$ & 0.0 & 0.40 & 0.25 \\
\hline Total & & 3.61 & 2.45 & 2.82 \\
\hline $\begin{array}{l}\text { Percent of total } \\
\text { Laboratory funding-BA }\end{array}$ & & 1.0 & 0.6 & 0.6 \\
\hline
\end{tabular}

${ }^{a}$ Figures include operating BA, capital equipment, and funded/budgeted construction.

\section{HA01-Environment, Safety, and Health}

No major shifts are expected in the remaining programs for environmental policy studies and analysis and environmental technical assistance. For six years, ORNL has supported the Office of Environmental Analyses in DOE in the development of energy resource assessment models and in the provision of background research for various energy policy issues. This support will continue. The sponsors of the Emergency Technology Program (ETP) plan to increase the research component of the program. Under the ETP, ORNL personnel review and assist in emergency planning and preparedness for environmental protection and public safety.

A new program, the Computation Performance Assessment Program, is utilizing existing expertise at ORNL in nuclear criticality safety analysis to examine a long-standing discrepancy between critical experiments with aqueous solutions of fissile materials and calculations of the experiments. The assessment requires research in the physics of criticality, modeling neutronics, computer programming, and calculations. The program is scheduled to run through the first quarter of FY 1984. Funding is also expected for a complementary program that entails experimentally testing the applicability of the ${ }^{252} \mathrm{Cf}$-source-driven neutron noise analysis method for monitoring for the criticality safety of large arrays of interacting units. Demonstration of feasibility for this application would allow implementation of this subcriticality monitoring method to a variety of nuclear fuel plant applications associated with chemical processing and fuel storage. 
HA01-Environment, Safety, and Health Program resource summary

\begin{tabular}{|c|c|c|c|c|c|c|c|c|c|c|c|c|c|c|c|c|}
\hline \multirow{2}{*}{$\begin{array}{c}(\$ \text { in Millions })^{a} \\
\text { (Personnel in FTEs) }\end{array}$} & \multicolumn{2}{|c|}{ FY 1982} & \multicolumn{2}{|c|}{ FY 1983} & \multicolumn{2}{|c|}{ FY 1984} & \multicolumn{2}{|c|}{ FY 1985} & \multicolumn{2}{|c|}{ FY 1986} & \multicolumn{2}{|c|}{ FY 1987} & \multicolumn{2}{|c|}{ FY 1988} & \multicolumn{2}{|c|}{ FY 1989} \\
\hline & BA & BO & BA & BO & BA & BO & BA & BO & BA & $\mathrm{BO}$ & BA & $\mathrm{BO}$ & BA & BO & BA & BO \\
\hline Total Operating & 6.0 & 5.8 & 3.5 & 3.8 & 2.0 & 2.0 & 2.5 & 2.5 & 2.5 & 2.5 & 2.5 & 2.5 & 2.5 & 2.5 & 2.5 & 2.5 \\
\hline Capital Equipment & 0.01 & & 0.08 & & 0.05 & & 0.07 & & 0.1 & & 0.1 & & 0.1 & & 0.1 & \\
\hline Construction & 0.0 & & 0.0 & & 0.0 & & 0.0 & & 0.0 & & 0.0 & & 0.0 & & 0.0 & \\
\hline $\begin{array}{l}\text { Total for major } \\
\text { programs }\end{array}$ & 6.0 & 5.8 & 3.6 & 3.8 & 2.1 & 2.0 & 2.6 & 2.5 & 2.6 & 2.5 & 2.6 & 2.5 & 2.6 & 2.5 & 2.6 & 2.5 \\
\hline Direct Personnel & 36.5 & & 24.3 & & 10.0 & & 12.0 & & 12.0 & & 12.0 & & 12.0 & & 12.0 & \\
\hline
\end{tabular}

${ }^{\circ}$ An $8.5 \%$ inflation factor has been used between FY 1983 and FY 1984 and between FY 1984 and FY 1985. FY 1986-FY 1989 amounts are in constant FY 1985 dollars.

\section{UB02-Power Supply and Reliability}

During FY 1981 and FY 1982, ORNL supported the Office of Energy Emergencies in the analysis of various energy emergency preparedness options, and this support will resume in FY 1984. Activities will include studies of electrical equipment availability in the event of a major equipment accident or incident.

UB02-Power Supply and Reliability Program resource summary

\begin{tabular}{|c|c|c|c|c|c|c|c|c|c|c|c|c|c|c|c|c|}
\hline \multirow{2}{*}{$\begin{array}{c}(\$ \text { in Millions) } \\
\text { (Personnel in FTEs) }^{a}\end{array}$} & \multicolumn{2}{|c|}{ FY 1982} & \multicolumn{2}{|c|}{ FY 1983} & \multicolumn{2}{|c|}{ FY 1984} & \multicolumn{2}{|c|}{ FY 1985} & \multicolumn{2}{|c|}{ FY 1986} & \multicolumn{2}{|c|}{ FY 1987} & \multicolumn{2}{|c|}{ FY 1988} & \multicolumn{2}{|c|}{ FY 1989} \\
\hline & BA & BO & BA & BO & BA & BO & BA & BO & BA & BO & BA & $\mathrm{BO}$ & BA & BO & BA & BO \\
\hline Cotal & 0.0 & 0.4 & 0.0 & 0.0 & 0.4 & 0.4 & 0.3 & 0.3 & 0.3 & 0.3 & 0.3 & 0.3 & 0.3 & 0.3 & 0.3 & 0.3 \\
\hline & 0.0 & & 0 & 0.0 & 0. & & 0 & & 0 & & 0 & & 0 & & 0 & \\
\hline Construct & 0.0 & & 0.0 & 0.0 & 0.0 & & 0.0 & & 0.0 & & 0.0 & & 0 & & 0 & \\
\hline $\begin{array}{l}\text { Total for major } \\
\text { program }\end{array}$ & 0.0 & 0.4 & 0.0 & 0.0 & 0.4 & 0.4 & 0.3 & 0.3 & 0.3 & 0.3 & 0.3 & 0.3 & 0.3 & 0.3 & 0.3 & 0.3 \\
\hline Direct Personnel & 0.0 & 1.8 & 0.0 & 0.0 & 0.3 & & 0.2 & & 0.2 & & 0.2 & & 0.2 & & 0.2 & \\
\hline
\end{tabular}

${ }^{a}$ An $8.5 \%$ inflation factor has been used between FY 1983 and FY 1984 and between FY 1984 and FY 1985. FY 1986-FY 1989 amounts are in constant FY 1985 dollars.

\section{Office of Policy, Planning, and Analysis}

Work for the Office of Policy, Planning, and Analysis is at a very modest level and is not expected to increase significantly. It involves work on energy-demand models and analyses that apply in the transportation and industrial sectors as well as work on an oil cartel model. Under sponsorship of the Division of Policy and Strategic Planning (under ASFE), ORNL and its subcontractors (Decision Focus, Inc., and Lewin and Associates) have also developed computer models of liquid and gaseous fuel supplies. These models provide a quantitative assessment of competitive supply technologies. They thus contribute to the development of the knowledge base required to reduce the vulnerability of the U.S. energy supply to disruptions potentially resulting from reliance on scarce and increasingly expensive conventional petroleum reserves. Only a single B\&R code (PE01) is involved. 
PE-Policy, Analysis, and Systems Studies Program resource summary

\begin{tabular}{|c|c|c|c|c|c|c|c|c|c|c|c|c|c|c|c|c|}
\hline \multirow{2}{*}{$\begin{array}{c}(\$ \text { in Millions })^{a} \\
\text { (Personnel in FTEs) }\end{array}$} & \multicolumn{2}{|c|}{ FY 1982} & \multicolumn{2}{|c|}{ FY 1983} & \multicolumn{2}{|c|}{ FY 1984} & \multicolumn{2}{|c|}{ FY 1985} & \multicolumn{2}{|c|}{ FY 1986} & \multicolumn{2}{|c|}{ FY 1987} & \multicolumn{2}{|c|}{ FY 1988} & \multicolumn{2}{|c|}{ FY 1989} \\
\hline & BA & BO & BA & BO & BA & BO & BA & BO & BA & BO & BA & BO & BA & BO & BA & $\mathrm{BO}$ \\
\hline Total Operating & 0.2 & 0.3 & 0.04 & 0.08 & 0.15 & 0.10 & 0.2 & 0.2 & 0.2 & 0.2 & 0.2 & 0.2 & 0.2 & 0.2 & 0.2 & 0.2 \\
\hline Capital Equipment & 0.0 & & 0.0 & & 0.01 & & 0.0 & & 0.0 & & 0.0 & & 0.0 & & 0.0 & \\
\hline Construction & 0.0 & & 0.0 & & 0.0 & & 0.0 & & 0.0 & . & 0.0 & & 0.0 & & 0.0 & \\
\hline $\begin{array}{l}\text { Total for major } \\
\text { programs }\end{array}$ & 0.2 & 0.3 & 0.04 & 0.08 & 0.16 & 0.10 & 0.2 & 0.2 & 0.2 & 0.2 & 0.2 & 0.2 & 0.2 & 0.2 & 0.2 & 0.2 \\
\hline Direct Personnel & 0.3 & & 0.2 & & 0.5 & & 0.8 & & 1.0 & & 1.0 & & 1.0 & & 1.0 & \\
\hline
\end{tabular}

${ }^{a}$ An $8.5 \%$ inflation factor has been used between FY 1983 and FY 1984 and between FY 1984 and FY 1985. FY 1986-FY 1989 amounts are in constant FY 1985 dollars.

\section{Federal Energy Regulatory Commission (FERC)}

ORNL's efforts for FERC are very modest, but they are projected to be stable throughout the planning cycle. Work primarily involves technical support to the Office of Electric Power Regulation in the area of National Environmental Policy Act (NEPA) compliance. This year, ORNL began a Draft Environmental Impact Statement for the Susitna hydroelectric project in Alaska. Budget authorization is currently under only one B\&R code (VP). ORNL is, however, prepared to expand its work for FERC should the need for additional support become clear.

VP-FERC Program resource summary

\begin{tabular}{|c|c|c|c|c|c|c|c|c|c|c|c|c|c|c|c|c|}
\hline \multirow{2}{*}{$\begin{array}{c}(\$ \text { in Millions) } \\
\text { (Personnel in FTEs) }\end{array}$} & \multicolumn{2}{|c|}{ FY 1982} & \multicolumn{2}{|c|}{ FY 1983} & \multicolumn{2}{|c|}{ FY 1984} & \multicolumn{2}{|c|}{ FY 1985} & \multicolumn{2}{|c|}{ FY 1986} & \multicolumn{2}{|c|}{ FY 1987} & \multicolumn{2}{|c|}{ FY 1988} & \multicolumn{2}{|c|}{ FY 1989} \\
\hline & BA & BO & $\mathbf{B A}$ & BO & BA & BO & BA & BO & $\mathbf{B A}$ & BO & BA & $\mathrm{BO}$ & BA & BO & BA & $\mathrm{BO}$ \\
\hline Total Operating & 0.0 & 0.03 & 0.3 & 0.3 & 0.7 & 0.6 & 0.6 & 0.6 & 0.7 & 0.7 & 0.7 & 0.7 & 0.7 & 0.7 & 0.7 & 0.7 \\
\hline Capital Equipment & 0.0 & & 0.0 & & 0.0 & & 0.0 & & 0.0 & & 0.0 & & 0.0 & & 0.0 & \\
\hline Construction & 0.0 & & 0.0 & & 0.0 & & 0.0 & & 0.0 & & 0.0 & & 0.0 & & 0.0 & \\
\hline $\begin{array}{l}\text { Total for major } \\
\text { programs }\end{array}$ & 0.0 & 0.03 & 0.3 & 0.3 & 0.7 & 0.6 & 0.6 & 0.6 & 0.7 & 0.7 & 0.7 & 0.7 & 0.7 & 0.7 & 0.7 & 0.7 \\
\hline Direct Personnel & 0.0 & & 2.4 & & 3.6 & & 3.5 & & 3.5 & & 3.5 & & 3.5 & & 3.5 & \\
\hline
\end{tabular}

${ }^{\circ}$ An $8.5 \%$ inflation factor has been used between FY 1983 and FY 1984 and between FY 1984 and FY 1985. FY 1986-FY 1989 amounts are in constant FY 1985 dollars.

${ }^{b}$ Covers VI01 program, which has no new BA in FY 1983.

\section{Assistant Secretary for Management and Administration (ASMA)}

ORNL currently has a minor amount of funding from ASMA under two B\&R codes (LA01 and WB00). The LA01 category covers activity related to DOE's Technical Information Center (TIC). This funding is expected to increase moderately throughout the planning cycle. The WB00 category covers an In-House Energy Management activity, which is scheduled for phaseout in FY 1984. 
LA/WB-ASMA Program resource summary

\begin{tabular}{|c|c|c|c|c|c|c|c|c|c|c|c|c|c|c|c|c|}
\hline \multirow{2}{*}{$\begin{array}{c}(\$ \text { in Millions })^{a} \\
(\text { Personnel in FTEs) }\end{array}$} & \multicolumn{2}{|c|}{ FY 1982} & \multicolumn{2}{|c|}{ FY 1983} & \multicolumn{2}{|c|}{ FY 1984} & \multicolumn{2}{|c|}{ FY 1985} & \multicolumn{2}{|c|}{ FY 1986} & \multicolumn{2}{|c|}{ FY 1987} & \multicolumn{2}{|c|}{ FY 1988} & \multicolumn{2}{|c|}{ FY 1989} \\
\hline & BA & BO & BA & BO & BA & BO & BA & BO & BA & BO & BA & $\mathrm{BO}$ & BA & BO & BA & BO \\
\hline & & & & & & & & & & & & & & & .4 & \\
\hline & 0.1 & & 0.06 & & 0.1 & & 0.1 & & 0.0 & & 0 & & .0 & & .0 & \\
\hline Con & & & 0.0 & & 0.0 & & 0.0 & & 0.0 & & 0 & & 0.0 & & 0.0 & \\
\hline $\begin{array}{l}\text { Total for ASMA } \\
\text { programs }\end{array}$ & 1.1 & 0.7 & 1.0 & 0.9 & 1.2 & 1.1 & 1.3 & 1.2 & 1.3 & 1.2 & 1.3 & 1.3 & 1.4 & 1.3 & 1.4 & 1.4 \\
\hline Direct Personnel & 0.3 & & 0.4 & & 0.0 & & 0.0 & & 0.0 & & 0.0 & & 0.0 & & 0.0 & \\
\hline
\end{tabular}

${ }^{a}$ An $8.5 \%$ inflation factor has been used between FY 1983 and FY 1984 and between FY 1984 and FY 1985. FY 1986-FY 1989 amounts are in constant FY 1985 dollars.

For purposes of this plan, Energy Conservation GPP is categorized as proposed construction under program WB. The distribution of this funding over the planning cycle is shown as follows:

WB-Proposed construction summary

\begin{tabular}{ccccccccc}
\hline (\$ in Millions) & FY 1982 & FY 1983 & FY 1984 & FY 1985 & FY 1986 & FY 1987 & FY 1988 & FY 1989 \\
\hline $\begin{array}{c}\text { Energy Conservation } \\
\text { GPP (WB Program) }\end{array}$ & 0.7 & 1.5 & 2.0 & 2.0 & 2.0 & 2.0 & 1.5 & 1.0 \\
\hline
\end{tabular}

\section{WORK FOR OTHER DOE INSTALLATIONS}

Roughly, $\$ 12.9$ million (3.6\%) of ORNL's FY 1983 operating and capital equipment BA was categorized as work for other DOE contractors and operations offices. The distribution of funds in this category over the planning cycle by major ORNL program area is given in Table 12 .

Table 12. Other DOE contractors and operations offices

\begin{tabular}{|c|c|c|c|c|c|c|c|c|}
\hline Program area & FY 1982 & FY 1983 & FY 1984 & FY 1985 & FY 1986 & FY 1987 & FY 1988 & FY 1989 \\
\hline Fission & 4.3 & 6.9 & 5.4 & 5.4 & 4.6 & 4.6 & 4.6 & 4.6 \\
\hline $\begin{array}{l}\text { Biomedical and } \\
\text { Environmental }\end{array}$ & 0.4 & 0.4 & 0.5 & 0.5 & 0.5 & 0.5 & 0.5 & 0.5 \\
\hline $\begin{array}{l}\text { Basic Physical } \\
\text { Sciences }\end{array}$ & 0.2 & 0.9 & 0.2 & 0.3 & 0.2 & 0.2 & 0.2 & 0.2 \\
\hline Fusion & 0.0 & 0.1 & 0.2 & 0.2 & 0.2 & 0.2 & 0.2 & 0.2 \\
\hline Fossil & 2.5 & 2.8 & 0.6 & 0.0 & 0.0 & 0.0 & 0.0 & 0.0 \\
\hline $\begin{array}{l}\text { Assessment and } \\
\text { Analysis }\end{array}$ & 0.0 & 0.2 & 0.0 & 0.0 & 0.0 & 0.0 & 0.0 & 0.0 \\
\hline Conservation & $\underline{0.1}$ & 1.6 & $\underline{0.1}$ & $\underline{0.1}$ & $\underline{0.5}$ & 0.5 & $\underline{0.5}$ & $\underline{0.5}$ \\
\hline Total & 7.5 & 12.9 & 7.0 & 6.5 & 6.0 & 6.0 & 6.0 & 6.0 \\
\hline $\begin{array}{l}\text { Percent of total } \\
\text { Laboratory funding }- \text { BA }\end{array}$ & 1.9 & 3.6 & 1.9 & 1.4 & 1.4 & 1.4 & 1.4 & 1.4 \\
\hline
\end{tabular}

${ }^{a}$ Figures include operating BA and capital equipment. 
Funding is substantial in only one of these areas. In the Fission area, ORNL is supplying technical assistance to several DOE contractors for a variety of projects. For example, personnel are being used (1) to perform safety analyses for Y-12 facilities used in the weapons program, (2) to contribute to the Gas Centrifuge Enrichment Program (GCEP) and Atomic Vapor Laser Isotope Separation (AVLIS) programs at K-25, and (3) to carry out a series of activities relating to operating LWRs for SNL. Continued funding in such programs is uncertain but is expected to show a gradual decrease through FY 1986 and then remain constant.

In the Fossil area, ORNL has provided substantial additional support to ASFE through activities funded by ORO. This work currently emphasizes technical support for process, materials, and environmental control technologies. This work is, however, expected to be phased out in FY 1984, while further funding for environmental work in fossil energy will be performed under the AA25 B\& $R$ code.

Funding in other program areas covers miscellaneous small projects for a large number of DOE contractors and other operations offices.

\section{WORK FOR OTHERS}

\section{Nuclear Regulatory Commission}

NRC is the largest single non-DOE supporter of ORNL activities. Almost $9 \%$ of ORNL's FY 1983 operating and capital equipment budget authorization came from the NRC, and this amounted to over $50 \%$ of all the Laboratory's Work for Others.

Through its various programs at ORNL, NRC receives research and technical support in areas in which the Laboratory has demonstrated significant expertise. These areas include structural analysis, materials evaluation, fission product behavior, accident sequence analysis, advanced instrumentation and diagnostics, human factors, reliability and operating data analysis, integrated risk assessment, and radiation dose and health effects. Based on the current NRC budget projections, which show an almost constant level of support for NRC over the next few years, ORNL's effort is expected to remain constant or increase only slightly (see Table 13).

Table 13. NRC Major Program summary ( $\$$ in Millions-Operating and Capital Equipment BA)

\begin{tabular}{lccc}
\hline Major program office & FY 1983 & FY 1984 & FY 1985 \\
\hline $\begin{array}{l}\text { Nuclear Reactor } \\
\text { Regulation }\end{array}$ & 2.62 & 2.38 & 1.73 \\
$\begin{array}{l}\text { Administration } \\
\begin{array}{l}\text { Nuclear Materials Safety } \\
\text { and Safeguards }\end{array}\end{array}$ & 0.43 & 0.42 & 0.44 \\
$\begin{array}{l}\text { Nuclear Regulatory } \\
\quad \text { Research }\end{array}$ & 22.08 & 21.29 & 22.85 \\
$\begin{array}{l}\text { Analysis and Evaluation } \\
\text { of Operational Data }\end{array}$ & 1.51 & 1.78 & 2.22 \\
$\begin{array}{l}\text { Other Offices } \\
\quad \text { Total }\end{array}$ & $\underline{0.69}$ & 1.04 & $\underline{1.56}$ \\
$\begin{array}{l}\text { Percent of total } \\
\text { Laboratory funding }\end{array}$ & 29.99 & 29.58 & 31.44 \\
\hline
\end{tabular}


The following descriptions of ORNL activities for NRC are divided into six categories reflecting work for the different offices funding the efforts.

\section{Nuclear Reactor Regulation}

As this activity's major task, ORNL assists in administering operator examinations for the Operator Licensing Branch of NRC. Also, the Laboratory provides technical consultation and specialized measurements to test methods for detecting anomalous behavior in LWRs.

\section{Administration}

The Laboratory furnishes technical support for this facet of NRC operations through the Radiation Shielding Information Center and the Technical Data Management Center. Both programs are well established and are expected to remain stable through FY 1989.

\section{Nuclear Materials Safety and Safeguards}

Our efforts in this area include shipping-cask analysis, environmental assessments of fuel cycle facilities, technical support in geochemical areas related to the licensing of radioactive waste repositories, and survey of metabolic data appropriate to high-level-waste dosimetry. Small increases in funding are expected in environmental assessment tasks and waste management.

\section{Nuclear Regulatory Research}

Support for the Office of Nuclear Regulatory Research is the largest NRC program at ORNL. Relatively large efforts are under way for obtaining an improved data base for behavior of fission products and aerosols in severe reactor accident situations and for the long-term behavior of reactor pressure vessels. A slight decrease in ORNL's effort is expected after FY 1985.

The Laboratory is proposing the funding of two new activities in LMFBR research which are logical extensions of our capabilities in LWR safety analyses. The thrust of the first proposal, the LMFBR operational safety program, is to establish a well-planned basic program that integrates diverse technologies such as reactor instrumentation, human factors in operations and maintenance, systems analysis, thermal hydraulics, and probabilistic risk assessment. The main objective is to perform analyses that will reveal operational precursors for serious safety incidents so that technical fixes can be incorporated in the reactor design prior to construction. Initial funding, beginning in FY 1984, is proposed to be $\$ 250 \mathrm{~K}$ and grow to $\$ 2.5 \mathrm{M}$ by FY 1989.

In the LMFBR fission product source-term program, the second proposal, ORNL would thoroughly assess accident progression and determine consequences to operating personnel and to the public by studying fission product chemistry and the behavior of aerosols of fission products and other interacting core and basic materials. Of particular importance is the effect of sodium on the behavior of these chemical systems under a wide range of conditions. Funding is proposed to begin in FY 1984 at $\$ 500 \mathrm{~K}$ and increase to $\$ 2.5 \mathrm{M}$ by FY 1989. 


\section{Analysis and Evaluation of Operational Data}

Over $70 \%$ of the funds from this office support the Sequence Coding and Search System (SCSS) and the Nuclear Safety Information Center (NSIC). The SCSS task involves the development and application of a new system for increasing the usefulness of the descriptive text contained in Licensee Event Reports. The NSIC work provides a focal point for the collection, storage, analysis, and dissemination of operating experimental data relevant to NRC-licensed activities. A moderate increase in funding is forecast for this office in the near term.

To expand and use fully the expertise available in this program, ORNL proposes a new activity using the various data bases from areas such as the Licensee Event Reports and plant maintenance reports. This reliability assurance system would broaden the data bases and the evaluation activities, thus increasing the usefulness of the total system both for NRC and the utilities. When fully implemented, the system is expected to be a user facility. The task will begin in FY 1984 at $\$ 150 \mathrm{~K}$ and increase to $\$ 500 \mathrm{~K}$ by FY 1986.

\section{Other Offices}

The Laboratory provides technical assistance in the conduct of inventory verification, analysis of special nuclear materials samples, and preparation of site-specific material standards. A slight increase in funding is anticipated.

NRC Program resource summary

\begin{tabular}{|c|c|c|c|c|c|c|c|c|c|c|c|c|c|c|c|c|}
\hline \multirow{2}{*}{$\begin{array}{c}\text { ( } \$ \text { in Millions) }{ }^{a} \\
\text { (Personnel in FTEs) }\end{array}$} & \multicolumn{2}{|c|}{ FY 1982} & \multicolumn{2}{|c|}{ FY 1983} & \multicolumn{2}{|c|}{ FY 1984} & \multicolumn{2}{|c|}{ FY 1985} & \multicolumn{2}{|c|}{ FY 1986} & \multicolumn{2}{|c|}{ FY 1987} & \multicolumn{2}{|c|}{ FY 1988} & \multicolumn{2}{|c|}{ FY 1989} \\
\hline & BA & BO & BA & BO & BA & BO & BA & BO & BA & BO & $\mathbf{B A}$ & BO & BA & BO & BA & BO \\
\hline Total Operating & 28.1 & 27.8 & 28.8 & 31.1 & 29.6 & 31.7 & 31.4 & 28.9 & 31.5 & 30.8 & 31.3 & 30.9 & 30.8 & 30.9 & 30.2 & 30.9 \\
\hline Capital Equipment & 0.0 & & 0.1 & & 0.0 & & 0.0 & & 0.0 & & 0.0 & & 0.0 & & 0.0 & \\
\hline Construction & 0.0 & & 0.0 & & 0.0 & & 0.0 & & 0.0 & & 0.0 & & 0.0 & & 0.0 & \\
\hline $\begin{array}{l}\text { Total for NRC } \\
\text { programs }\end{array}$ & 28.9 & 27.8 & 29.9 & 31.1 & 29.6 & 31.7 & 31.4 & 28.9 & 31.5 & 30.8 & 31.3 & 30.9 & 30.8 & 30.9 & 30.2 & 30.9 \\
\hline Direct Personnel & 179.0 & & 179.0 & & 180.2 & & 166.6 & & 175.6 & & 173.7 & & 170.4 & & 167.7 & \\
\hline
\end{tabular}

aA 8.5\% inflation factor has been used between FY 1983 and FY 1984 and between FY 1984 and FY 1985. FY 1986-FY 1989 amounts are in constant FY 1985 dollars.

\section{Department of Defense (DOD)}

ORNL performs work for four primary branches of DOD-the Army, Navy, Air Force, and Defense Nuclear Agency. This work is projected to grow to a small but significant fraction of the Laboratory's total budget in this planning cycle (see Table 14). 
Table 14. DOD Major Program summary ( $\$$ in Millions-Operating and Capital Equipment BA)

\begin{tabular}{lccc}
\hline Major program office & FY 1983 & FY 1984 & FY 1985 \\
\hline Army & 2.81 & 6.52 & 9.35 \\
Navy & 3.70 & 15.00 & 17.21 \\
Air Force & 0.70 & 0.73 & 0.97 \\
Defense Nuclear Agency & $\underline{0.49}$ & $\underline{0.50}$ & $\underline{0.53}$ \\
\cline { 2 - 4 } Total & 7.70 & 22.75 & 28.06 \\
Percent of total & 2.3 & 5.7 & 6.0 \\
Laboratory funding & & & \\
\hline
\end{tabular}

Army

ORNL's research for the Army primarily involves physical, chemical, and toxicological characterization of chemicals (and their degradation products) of interest to the Army. Examples include diesel fuel, synthetic and alternative fuels, fog oil, dyes, phosphorus formulations, explosives, and sorbent compounds. Funding for Army programs at ORNL has increased from $\$ 1.6$ million in FY 1981 to $\$ 2.8$ million in FY 1983, with further increases expected in the coming years. Studies of the adverse health and environmental effects of diesel fuel and military obscurants will be completed in early FY 1984, but we anticipate receiving new work on other substances in the future.

ORNL also began new activities in data management and analysis for the Army in FY 1983. New work for the Military Traffic Management Command focuses on implementation of concepts and tools to allow agencies such as the Army Material Development and Readiness Command and the Army Civilian Personnel Center to integrate state-of-the-art hardware and software data systems into key programs. The aim is to allow such agencies to keep pace with rapidly developing technology vital to effective management, decision-making, and strategic planning.

Other ORNL efforts for the Army include studying the feasibility of using U.S. Army high-volume hazardous waste streams as supplementary feedstocks in industrial boilers, validating data for the Energy Conservation Investment Program, and performing a development study for an Energy Conservation Technical Information and Analysis Center. Our assistance with analysis of environmental matters for the Army Corps of Engineers and the Waterways Experiment Station continues. We have studied possible health and environmental effects of munition wastes and in FY 1984 will begin an assessment of munition production waste disposal methods.

\section{Navy}

ORNL work for the Navy continues at steady modest levels in the areas of waste disposal, heatpump improvements, radiac instruments, and scientific tasks for the Office of Naval Research. Work is growing in the areas of electronic data processing, validation, and methodology for the Navy Regional Data Automation Center, the Navy Sea Systems Command, Naval Air Systems Command, Naval Military Personnel Command, Naval Civilian Personnel Command, and in the Navy Weapons Engineering Support activity. Work has also been initiated for the Navy Material Command on buildings energy use and technology transfer issues, and technology R\&D is being 
conducted at a low level for the Fuels Technology, Materials Handling, and Information Systems programs in the Navy Supply Systems Command.

In providing research and technical assistance to develop and improve automated data systems, there is an expansion of work at ORNL to bring Navy systems to state of the art in integrated hardware/software technologies. R\&D being supported by the Navy also includes concept and methodology development and original research on the building blocks of artificial intelligence and its use, including expert systems, decision support systems, knowledge acquisition, and representation techniques. R\&D on data system design, data modeling, and information architecture to improve the quality and responsiveness of technical information systems and models to match increasing demands represents key aspects of technology development in the area. Combining data base management methodology with predictive systems analysis techniques is an integral part of Navy technical support activities. ORNL activities will be enhanced during FY 1984 and FY 1985, with funding being available to establish a data systems resources management laboratory that will consist of advanced data processing and management tools that can be used for system experimentation and prototype system design efforts.

\section{Air Force}

As part of a rapidly growing effort, the regional and national cartographic data bases developed and maintained at ORNL are being analyzed to provide a site-screening capability for the $M X$ missile program. Growth is also anticipated in the study of charged-particle interactions with communications materials. Work on computation techniques for sparse matrices is expected to continue at a constant level. Other sizeable Air Force-sponsored projects include an investigation of the suitability of HTGR power sources for deep-based MX missile sites and the development of a generic chemical characterization protocol for hazardous waste disposal practices at DOD facilities.

\section{Defense Nuclear Agency}

The major activities in this area are associated with the Radiation Shielding Information Center and with radiation transport studies. Analytical methods and related nuclear data sets for calculating the transport of weapons radiations are developed, evaluated, and disseminated. In addition, specific design-support analyses for difficult problems in radiation shielding are provided. These activities are projected to continue at essentially constant levels.

DOD Program resource summary

\begin{tabular}{|c|c|c|c|c|c|c|c|c|c|c|c|c|c|c|c|c|}
\hline \multirow{2}{*}{$\begin{array}{c}\text { ( } \$ \text { in Millions) } \\
\text { (Personnel in FTEs) }\end{array}$} & \multicolumn{2}{|c|}{ FY 1982} & \multicolumn{2}{|c|}{ FY 1983} & \multicolumn{2}{|c|}{ FY 1984} & \multicolumn{2}{|c|}{ FY 1985} & \multicolumn{2}{|c|}{ FY 1986} & \multicolumn{2}{|c|}{ FY 1987} & \multicolumn{2}{|c|}{ FY 1988} & \multicolumn{2}{|c|}{ FY 1989} \\
\hline & BA & BO & BA & BO & $\mathbf{B A}$ & BO & $\mathbf{B A}$ & BO & BA & BO & BA & BO & BA & BO & BA & BO \\
\hline Total Operating & 4.0 & 4.0 & 7.7 & 7.7 & 20.8 & 15.5 & 25.6 & 21.3 & 26.0 & 24.0 & 26.5 & 25.5 & 26.5 & 26.5 & 26.5 & 26.5 \\
\hline Capital Equipment & 0.1 & & 0.05 & & 1.9 & & 2.5 & & 1.6 & & 1.5 & & 1.5 & & 1.5 & \\
\hline Construction & 0.0 & & 0.0 & & 0.0 & & 0.0 & & 0.0 & & 0.0 & & 0.0 & & 0.0 & \\
\hline $\begin{array}{l}\text { Total for DOD } \\
\text { programs }\end{array}$ & 4.1 & 4.0 & 7.7 & 7.7 & 22.7 & 15.5 & 28.1 & 21.3 & 27.6 & 24.0 & 28.0 & 25.5 & 28.0 & 26.5 & 28.0 & 26.5 \\
\hline Direct Personnel & 40.4 & & 42.6 & & 81.1 & & 97.3 & & 99.0 & & 96.0 & & 96.0 & & 96.0 & \\
\hline
\end{tabular}

aAn $8.5 \%$ inflation factor has been used between FY. 1983 and FY 1984 and between FY 1984 and FY 1985. FY 1986-FY 1989 amounts are in constant FY 1985 dollars. 


\section{Department of the Interior (DOI)}

ORNL conducts research for several DOI organizations: the Bureau of Mines, Office of Water Research and Technology, Office of Surface Mining, U.S. Geological Survey, Bureau of Land Management (BLM), Fish and Wildlife Service, and the National Park Service. A new interagency agreement was initiated in September 1983 to provide BLM with technical assistance and research support in the areas of natural resource management; analysis and assessment; and data system design, development, and implementation. This new work will substantially increase ORNL's total funding from DOI to a level of about \$2.5 million in FY 1984. In addition, work was initiated for the Minerals Management Service's (MMS's) Royalty Management Program in October 1982 and the Laboratory may also be asked to assume a support role for the Bureau of Indian Affairs in the preparation of environmental compliance documents required under NEPA.

During FY 1983, a major effort was completed for DOI's Office of Surface Mining. This was the inventory of abandoned mine land which was done in collaboration with TVA, East Tennessee State University, and Lockheed.

For several years, we have also provided technical assistance to the U.S.-Israel desalination project. More recently, we have prepared related technology transfer documents. This project is funded one-half by Israel and one-half by the U.S. Department of State. These State Department funds are transferred to the Office of Water Research, Bureau of Reclamation. This work is expected to continue through March 1984. Further work that may span several years will depend on the results of a current worldwide market survey for large desalination plants. This survey is also being managed by ORNL.

DOI Program resource summary

\begin{tabular}{|c|c|c|c|c|c|c|c|c|c|c|c|c|c|c|c|c|}
\hline \multirow{2}{*}{$\begin{array}{c}(\$ \text { in Millions })^{a} \\
(\text { Personnel in FTEs) }\end{array}$} & \multicolumn{2}{|c|}{ FY 1982} & \multicolumn{2}{|c|}{ FY 1983} & \multicolumn{2}{|c|}{ FY 1984} & \multicolumn{2}{|c|}{ FY 1985} & \multicolumn{2}{|c|}{ FY 1986} & \multicolumn{2}{|c|}{ FY 1987} & \multicolumn{2}{|c|}{ FY 1988} & \multicolumn{2}{|c|}{ FY 1989} \\
\hline & BA & BO & BA & BO & BA & BO & BA & BO & BA & BO & BA & BO & BA & BO & BA & BO \\
\hline Total Operating & 1.5 & 1.5 & 1.2 & 1.2 & 2.5 & 2.5 & 2.6 & 2.6 & 2.6 & 2.6 & 2.6 & 2.6 & 2.6 & 2.6 & 2.6 & 2.6 \\
\hline Capital Equipment & 0.0 & & 0.0 & & 0.0 & & 0.0 & & 0.0 & & 0.0 & & 0.0 & & 0.0 & \\
\hline Construction & 0.0 & & 0.0 & & 0.0 & & 0.0 & & 0.0 & & 0.0 & & 0.0 & & 0.0 & \\
\hline $\begin{array}{l}\text { Total for DOI } \\
\text { programs }\end{array}$ & 1.5 & 1.5 & 1.2 & 1.2 & 2.5 & 2.5 & 2.6 & 2.6 & 2.6 & 2.6 & 2.6 & 2.6 & 2.6 & 2.6 & 2.6 & 2.6 \\
\hline Direct Personnel & 4.0 & & 5.3 & & 8.0 & & 8.0 & & 8.0 & & 8.0 & & 8.0 & & 8.0 & \\
\hline
\end{tabular}

${ }^{a}$ An $8.5 \%$ inflation factor has been used between FY 1983 and FY 1984 and between FY 1984 and FY 1985. FY 1986-FY 1989 amounts are in constant FY 1985 dollars.

\section{Department of Health and Human Services}

DHHS supports research in carcinogenesis, genetics, and toxicology. DHHS funding is expected to remain reasonably constant over the next five years. The various branches of DHHS supporting our work include the National Cancer Institute (NCI); the National Institute of Environmental Health Sciences; the National Heart, Lung, and Blood Institute; the National Institute of General Medical Sciences; the National Institute of Child Health and Human Development; the National Institute on Drug Abuse; the Food and Drug Administration (FDA); the National Library of Medicine 
(NLM); and the National Toxicology Program (NTP). We expect an expanded effort in radiation carcinogenesis research supported by NCI. For FDA, NLM, and NTP, we are developing nationally and internationally available data bases in the areas of genetic, reproductive, and general toxicology. We expect additional funding in FY 1984 from the DHHS portion of the superfund money for expansion of our toxicology data bases. This effort is designed to assist in assessing the potential human and environmental health risks of hazardous waste cleanup efforts.

A major issue concerning work done at ORNL for DHHS surfaced during late 1982. ORNL was informed that indirect costs for grants would no longer be allowed. The deficit for these indirect costs in 1983-approximately $\$ 300,000$-represented a major unanticipated cost. DOE/OHER has negotiated with DHHS, and the issue appears to have been partially resolved. We will be able to submit proposals for and accept new funds; however, the $\$ 300,000$ deficit remains an issue.

DHHS Program resource summary

\begin{tabular}{|c|c|c|c|c|c|c|c|c|c|c|c|c|c|c|c|c|}
\hline \multirow{2}{*}{$\begin{array}{c}(\$ \text { in Millions) } \\
\text { (Personnel in FTEs) }\end{array}$} & \multicolumn{2}{|c|}{ FY 1982} & \multicolumn{2}{|c|}{ FY 1983} & \multicolumn{2}{|c|}{ FY 1984} & \multicolumn{2}{|c|}{ FY 1985} & \multicolumn{2}{|c|}{ FY 1986} & \multicolumn{2}{|c|}{ FY 1987} & \multicolumn{2}{|c|}{ FY 1988} & \multicolumn{2}{|c|}{ FY 1989} \\
\hline & BA & BO & BA & BO & $\mathbf{B A}$ & BO & BA & BO & BA & BO & BA & BO & $\mathbf{B A}$ & BO & BA & BO \\
\hline Total Operating & 5.9 & 5.9 & 5.0 & 5.0 & 5.4 & 5.4 & 5.9 & 5.9 & 5.9 & 5.9 & 5.9 & 5.9 & 5.9 & 5.9 & 5.9 & 5.9 \\
\hline Capital Equipment & 0.0 & & 0.0 & & 0.0 & & 0.0 & & 0.0 & & 0.0 & & 0.0 & & 0.0 & \\
\hline Construction & 0.0 & & 0.0 & & 0.0 & & 0.0 & & 0.0 & & 0.0 & & 0.0 & & 0.0 & \\
\hline $\begin{array}{l}\text { Total for DHHS } \\
\text { programs }\end{array}$ & 5.9 & 5.9 & 5.0 & 5.0 & 5.4 & 5.4 & 5.9 & 5.9 & 5.9 & 5.9 & 5.9 & 5.9 & 5.9 & 5.9 & 5.9 & 5.9 \\
\hline Direct Personnel & 58.2 & & 48.4 & & 41.0 & & 41.0 & & 41.0 & & 41.0 & & 41.0 & & 41.0 & \\
\hline
\end{tabular}

${ }^{\circ}$ An $8.5 \%$ inflation factor has been used between FY 1983 and FY 1984 and between FY 1984 and FY 1985. FY 1986-FY 1989 amounts are in constant FY 1985 dollars.

\section{Environmental Protection Agency}

Overall, our EPA program will continue at about the same level of effort throughout the planning cycle as in FY 1983, with some fluctuations in specific program areas. Our work for EPA addresses numerous health and environmental problems and issues-particularly research into the toxic effects of pollutants associated with energy-production processes and waste disposal. Quantitative mutagenicity testing is proceeding but at a lower level of effort than in previous years. EPAsupported research on environmental toxicology of trace contaminants is declining, whereas risk assessment and waste leachate characterization activities are expected to continue at present levels. Acidic precipitation research activities are increasing, with major emphasis on the effects of acidic precipitation on agricultural and natural systems and on ion mobility in soils. ORNL has been assisting the Environmental Results Branch of the Office of Management Systems and Evaluation in EPA to develop computer analysis capabilities that will allow EPA to better formulate environmental regulatory policy.

The development of data bases such as (1) Chemicals Identified in Human Biological Media, (2) Feral and Food Animals, and (3) Perinatal Organ Development of Humans and Laboratory Animals, along with the preparation of specialized reviews and assessment reports, assists EPA in assessing the potential health effects of chemicals and in extrapolating animal data to man. In addition to the continuing Gene-Tox Program for evaluating mutagenicity bioassay systems, 
significant portions of the Environmental Mutagens, Teratogens, and Carcinogens Data Base development efforts are also being performed in support of EPA programs. The continuing turnover of EPA management, the reductions in funding, and the administrative problems resulting from these factors will continue to pose significant obstacles to smooth ORNL-EPA cooperation for the immediate future.

EPA Program resource summary

\begin{tabular}{|c|c|c|c|c|c|c|c|c|c|c|c|c|c|c|c|c|}
\hline \multirow{2}{*}{$\begin{array}{c}(\$ \text { in Millions })^{a} \\
(\text { Personnel in FTEs) }\end{array}$} & \multicolumn{2}{|c|}{ FY 1982} & \multicolumn{2}{|c|}{ FY 1983} & \multicolumn{2}{|c|}{ FY 1984} & \multicolumn{2}{|c|}{ FY 1985} & \multicolumn{2}{|c|}{ FY 1986} & \multicolumn{2}{|c|}{ FY 1987} & \multicolumn{2}{|c|}{ FY 1988} & \multicolumn{2}{|c|}{ FY 1989} \\
\hline & BA & BO & BA & BO & BA & BO & BA & BO & BA & $\mathrm{BO}$ & BA & BO & BA & BO & BA & BO \\
\hline Total Operating & 6.1 & 6.1 & 4.7 & 4.7 & 5.2 & 5.2 & 5.7 & 5.7 & 5.7 & 5.7 & 5.7 & 5.7 & 5.7 & 5.7 & 5.7 & 5.7 \\
\hline Capital Equipment & 0.01 & & 0.0 & & 0.01 & & 0.01 & & 0.03 & & 0.03 & & 0.03 & & 0.03 & \\
\hline Construction & 0.0 & & 0.0 & & 0.0 & & 0.0 & & 0.0 & & 0.0 & & 0.0 & & 0.0 & \\
\hline $\begin{array}{l}\text { Total for EPA } \\
\text { programs }\end{array}$ & 6.1 & 6.1 & 4.7 & 4.7 & 5.2 & 5.2 & 5.7 & 5.7 & 5.7 & 5.7 & 5.7 & 5.7 & 5.7 & 5.7 & 5.7 & 5.7 \\
\hline Direct Personnel & 60.0 & & 43.9 & & 50.0 & & 50.0 & & 50.0 & & 50.0 & & 50.0 & & 50.0 & \\
\hline
\end{tabular}

${ }^{a}$ An $8.5 \%$ inflation factor has been used between FY 1983 and FY 1984 and between FY 1984 and FY 1985. FY 1986-FY 1989 amounts are in constant FY 1985 dollars.

\section{National Science Foundation (NSF)}

The NSF, in conjunction with DOE, continues to provide support for the National Center for Small Angle Scattering Research (NCSASR). This is a national user-dedicated facility which makes two main instruments available to users: the NSF-constructed, 30-m small-angle neutron-scattering instrument (SANS) and the DOE-constructed, 10-m small angle X-ray scattering camera (SAXS). These instruments are intended to provide state-of-the-art capability for investigating structures of condensed matter on the scale of tens to hundreds of angstroms. These instruments are used extensively for materials science research, as well as research in biology, chemistry, polymer science, and diffraction physics.

Because of our unique position as a leader in systems and theoretical ecology, ORNL plays a strong role in these fields and works closely with various universities. NSF recognizes ORNL's leadership in ecosystem research and provides support for the study of material spiraling in stream ecosystems as an approach for the analysis of the transport and retention of nutrients and organic matter, for the study of the terrestrial biosphere's role in the global carbon cycle, and for the development and application of new methodologies for analyzing ecosystem-level problems. A slight increase in funds for our biotechnology program is also expected beginning FY 1985.

NSF Program resource summary

\begin{tabular}{|c|c|c|c|c|c|c|c|c|c|c|c|c|c|c|c|c|}
\hline \multirow{2}{*}{$\begin{array}{c}(\$ \text { in Millions })^{a} \\
\text { (Personnel in FTEs) }\end{array}$} & \multicolumn{2}{|c|}{ FY 1982} & \multicolumn{2}{|c|}{ FY 1983} & \multicolumn{2}{|c|}{ FY 1984} & \multicolumn{2}{|c|}{ FY 1985} & \multicolumn{2}{|c|}{ FY 1986} & \multicolumn{2}{|c|}{ FY 1987} & \multicolumn{2}{|c|}{ FY 1988} & \multicolumn{2}{|c|}{ FY 1989} \\
\hline & BA & BO & BA & BO & $\mathbf{B A}$ & BO & BA & BO & BA & BO & BA & BO & BA & BO & BA & BO \\
\hline Total Operating & 1.8 & 1.8 & 2.0 & 2.0 & 2.4 & 2.4 & 2.8 & 2.8 & 2.8 & 2.8 & 2.8 & 2.8 & 2.8 & 2.8 & 2.8 & 2.8 \\
\hline Capital Equipment & 0.07 & & 0.0 & & 0.0 & & 0.0 & & 0.0 & & 0.0 & & 0.0 & & 0.0 & \\
\hline Construction & 0.0 & & 0.0 & & 0.0 & & 0.0 & & 0.0 & & 0.0 & & 0.0 & & 0.0 & \\
\hline $\begin{array}{l}\text { Total for NSF } \\
\text { programs }\end{array}$ & 1.9 & 1.8 & 2.0 & 2.0 & 2.4 & 2.4 & 2.8 & 2.8 & 2.8 & 2.8 & 2.8 & 2.8 & 2.8 & 2.8 & 2.8 & 2.8 \\
\hline Direct Personnel & 15.9 & & 12.6 & & 15.0 & & 17.0 & & 17.0 & & 17.0 & & 17.0 & & 17.0 & \\
\hline
\end{tabular}

${ }^{a}$ An $8.5 \%$ inflation factor has been used between FY 1983 and FY 1984 and between FY 1984 and FY 1985. FY 1986-FY 1989 amounts are in constant FY 1985 dollars. 


\section{Tennessee Valley Authority}

ORNL work for TVA has declined from levels of prior years. The largest fraction of current support is in the area of coal preparation and other fossil-energy applications. This work is followed by conservation evaluation work and then by a variety of miscellaneous analytical and testing services.

TVA Program resource summary

\begin{tabular}{|c|c|c|c|c|c|c|c|c|c|c|c|c|c|c|c|c|}
\hline \multirow{2}{*}{$\begin{array}{c}\text { ( } \$ \text { in Millions) })^{a} \\
\text { (Personnel in FTEs) }\end{array}$} & \multicolumn{2}{|c|}{ FY 1982} & \multicolumn{2}{|c|}{ FY 1983} & \multicolumn{2}{|c|}{ FY 1984} & \multicolumn{2}{|c|}{ FY 1985} & \multicolumn{2}{|c|}{ FY 1986} & \multicolumn{2}{|c|}{ FY 1987} & \multicolumn{2}{|c|}{ FY 1988} & \multicolumn{2}{|c|}{ FY 1989} \\
\hline & BA & BO & BA & BO & BA & BO & BA & BO & BA & BO & BA & BO & $\mathbf{B A}$ & BO & BA & BO \\
\hline $\begin{array}{l}\text { Total Operating } \\
\text { Capital Equipment }\end{array}$ & 1.1 & 1.1 & 0.4 & 0.4 & 0.7 & 0.7 & 0.7 & 0.7 & 0.7 & 0.7 & $\begin{array}{l}0.7 \\
0.0\end{array}$ & 0.7 & $\begin{array}{l}0.7 \\
0.0\end{array}$ & 0.7 & $\begin{array}{l}0.7 \\
0.0\end{array}$ & 0.7 \\
\hline Construction & 0.0 & & 0.0 & & 0.0 & & & & & & 0.0 & & 0.0 & & 0.0 & \\
\hline $\begin{array}{c}\text { Total for TVA } \\
\text { programs }\end{array}$ & 1.1 & 1.1 & 0.4 & 0.4 & 0.7 & 0.7 & 0.7 & 0.7 & 0.7 & 0.7 & 0.7 & 0.7 & 0.7 & 0.7 & 0.7 & 0.7 \\
\hline Direct Personnel & 8.2 & & 2.5 & & 5.7 & & 5.5 & & 5.5 & & 5.5 & & 5.5 & & 5.5 & \\
\hline
\end{tabular}

${ }^{a}$ An $8.5 \%$ inflation factor has been used between FY 1983 and FY 1984 and between FY 1984 and FY 1985. FY 1986-FY 1989 amounts are in constant FY 1985 dollars.

\section{Federal Emergency Management Agency (FEMA)}

Programs for FEMA involve reseach in support of national civil preparedness in the event of nuclear attack or emergency and other FEMA missions. Our areas of support include civil, electrical, and mechanical engineering; electronics; computer sciences; physics; and social sciences. Diverse topics are being studied, including designing, or adapting current designs, of earth-covered housing for blast and fallout protection; forecasting of radiation levels from fallout caused by multiple nuclear detonations; and developing concepts and handbooks to strengthen the national radiological defense system. ORNL is continuing to provide engineering assistance relative to radiation detection. This assistance includes the development of cheap, reliable, and rugged dosimeter chargers; technical assistance related to dosimeter manufacture; and consultation and assessment related to radiation detection instrumentation. Work for FEMA in these areas is expected to continue at a stable level in the future.

FEMA Program resource summary

\begin{tabular}{|c|c|c|c|c|c|c|c|c|c|c|c|c|c|c|}
\hline \multirow{2}{*}{$\begin{array}{c}(\$ \text { in Millions) } \\
\text { (Personnel in FTEs) }\end{array}$} & \multicolumn{2}{|c|}{ FY 1983} & \multicolumn{2}{|c|}{ FY 1984} & \multicolumn{2}{|c|}{ FY 1985} & \multicolumn{2}{|c|}{ FY 1986} & \multicolumn{2}{|c|}{ FY 1987} & \multicolumn{2}{|c|}{ FY 1988} & \multicolumn{2}{|c|}{ FY 1989} \\
\hline & $\mathbf{B A}$ & BO & BA & BO & BA & BO & $\mathbf{B A}$ & BO & BA & BO & $\mathbf{B A}$ & BO & BA & BO \\
\hline Total Operating & 1.9 & 1.9 & 1.4 & 1.4 & 1.5 & 1.5 & 1.5 & 1.5 & 1.5 & 1.5 & 1.5 & 1.5 & 1.5 & 1.5 \\
\hline Capital Equipment & 0.03 & & 0.0 & & 0.0 & & 0.0 & & 0.0 & & 0.0 & & 0.0 & \\
\hline Construction & 0.0 & & 0.0 & & 0.0 & & 0.0 & & 0.0 & & 0.0 & & 0.0 & \\
\hline $\begin{array}{l}\text { Total for FEMA } \\
\text { programs }\end{array}$ & 1.9 & 1.9 & 1.4 & 1.4 & 1.5 & 1.5 & 1.5 & 1.5 & 1.5 & 1.5 & 1.5 & 1.5 & 1.5 & 1.5 \\
\hline Direct Personnel & 14.6 & & 8.5 & & 9.0 & & 10.0 & & 10.0 & & 10.0 & & 10.0 & \\
\hline
\end{tabular}

${ }^{\circ}$ An $8.5 \%$ inflation factor has been used between FY 1983 and FY 1984 and between FY 1984 and FY 1985. FY 1986-FY 1989 amounts are in constant FY 1985 dollars. 


\section{Synthetic Fuels Corporation (SFC)}

ORNL assisted SFC in planning environmental and socioeconomic studies as part of the work on the Recommended Comprehensive Strategy Report to Congress. These studies were to determine regional carrying and assimilation capacities and analyze regional environmental factors related to synthetic fuels. Future work for SFC is dependent upon the needs of SFC.

SFC Program resource summary

\begin{tabular}{|c|c|c|c|c|c|c|c|c|c|c|c|c|c|c|}
\hline \multirow{2}{*}{$\begin{array}{c}(\$ \text { in Millions })^{a} \\
(\text { Personnel in FTEs) }\end{array}$} & \multicolumn{2}{|c|}{ FY 1983} & \multicolumn{2}{|c|}{ FY 1984} & \multicolumn{2}{|c|}{ FY 1985} & \multicolumn{2}{|c|}{ FY 1986} & \multicolumn{2}{|c|}{ FY 1987} & \multicolumn{2}{|c|}{ FY 1988} & \multicolumn{2}{|c|}{ FY 1989} \\
\hline & BA & BO & BA & BO & BA & BO & BA & BO & BA & BO & BA & BO & BA & BO \\
\hline Total Operating & 0.03 & 0.03 & 0.0 & 0.0 & 0.0 & 0.0 & 0.0 & 0.0 & 0.0 & 0.0 & 0.0 & 0.0 & 0.0 & 0.0 \\
\hline Capital Equipment & 0.0 & & 0.0 & & 0.0 & & 0.0 & & 0.0 & & 0.0 & & 0.0 & \\
\hline Construction & 0.0 & & 0.0 & & 0.0 & & 0.0 & & 0.0 & & 0.0 & & 0.0 & \\
\hline $\begin{array}{l}\text { Total for SFC } \\
\text { programs }\end{array}$ & 0.03 & 0.03 & 0.0 & 0.0 & 0.0 & 0.0 & 0.0 & 0.0 & 0.0 & 0.0 & 0.0 & 0.0 & 0.0 & 0.0 \\
\hline Direct Personnel & 0.3 & & 0.0 & & 0.0 & & 0.0 & & 0.0 & & 0.0 & & 0.0 & \\
\hline
\end{tabular}

${ }^{a}$ An $8.5 \%$ inflation factor has been used between FY 1983 and FY 1984 and between FY 1984 and FY 1985. FY 1986-FY 1989 amounts are in constant FY 1985 dollars.

\section{Department of Transportation (DOT)}

ORNL's Conservation and Renewable Energy Program performs work on several small projects for DOT, including studies of vehicle travel classification, laboratory testing of emissions as a function of fuel flow and manifold pressure, and analysis and modeling of traffic data. ORNL expects to continue to provide technical support to DOT for research related to transportation energy issues through the planning cycle.

DOT Program resource summary

\begin{tabular}{|c|c|c|c|c|c|c|c|c|c|c|c|c|c|c|c|c|}
\hline \multirow{2}{*}{$\begin{array}{c}(\$ \text { in Millions) })^{a} \\
(\text { Personnel in FTEs) }\end{array}$} & \multicolumn{2}{|c|}{ FY 1982} & \multicolumn{2}{|c|}{ FY 1983} & \multicolumn{2}{|c|}{ FY 1984} & \multicolumn{2}{|c|}{ FY 1985} & \multicolumn{2}{|c|}{ FY 1986} & \multicolumn{2}{|c|}{ FY 1987} & \multicolumn{2}{|c|}{ FY 1988} & \multicolumn{2}{|c|}{ FY 1989} \\
\hline & BA & BO & BA & BO & BA & BO & BA & BO & BA & BO & BA & BO & BA & BO & $\mathbf{B A}$ & $\mathbf{B O}$ \\
\hline Total Operating & 0.3 & 0.4 & 0.3 & 0.3 & 0.3 & 0.3 & 0.4 & 0.4 & 0.4 & 0.4 & 0.4 & 0.4 & 0.4 & 0.4 & 0.4 & 0.4 \\
\hline Capital Equipment & 0.0 & & 0.03 & & 0.0 & & 0.0 & & 0.0 & & 0.0 & & 0.0 & & 0.0 & \\
\hline Construction & 0.0 & & 0.0 & & 0.0 & & 0.0 & & 0.0 & & 0.0 & & 0.0 & & 0.0 & \\
\hline $\begin{array}{l}\text { Total for DOT } \\
\text { programs }\end{array}$ & 0.3 & 0.4 & 1.5 & 0.4 & 0.3 & 0.3 & 0.4 & 0.4 & 0.4 & 0.4 & 0.4 & 0.4 & 0.4 & 0.4 & 0.4 & 0.4 \\
\hline Direct Personnel & 3.4 & & 2.7 & & 2.7 & & 2.3 & & 3.0 & & 3.0 & & 3.0 & & 3.0 & \\
\hline
\end{tabular}

${ }^{a}$ An $8.5 \%$ inflation factor has been used between FY 1983 and FY 1984 and between FY 1984 and FY 1985. FY 1986-FY 1989 amounts are in constant FY 1985 dollars.

\section{Other Federal Agencies}

ORNL also does work for a variety of other federal agencies. The Consumer Product Safety Commission, NASA, the National Oceanic and Atmospheric Administration, and the Department 
of Agriculture all support small amounts of life sciences research totaling approximately $\$ 1.5$ million in FY 1983. The Consumer Product Safety Commission primarily provides funds for our research on indoor air quality, which is expanding.

Some $\$ 372,000$ in support for FY 1983 also came from the U.S. Department of State for work performed for the Agency for International Development (AID) and the (IAEA). ORNL support for AID includes technical assistance with energy assessments, evaluations of technology options, and energy-related institution-building to meet the needs of less developed countries. The ORNL Fusion Program will also participate in toroidal-device studies for the government of Spain. Funding for the latter studies is expected to come through a U.S. federal agency, possibly AID.

Research support for data systems design, development, and implementation activities was initiated by the Immigration and Naturalization Service (INS) with $\$ 350,000$ in support for FY 1983. INS will expand this work in FY 1984 to include instrumentation R\&D for remote-sensing, alarming, and logging systems; electronic signal processing; and development of analytical models for predicting immigration trends and patterns as well as population distribution studies.

Other Federal Agencies Program resource summary

\begin{tabular}{|c|c|c|c|c|c|c|c|c|c|c|c|c|c|c|c|c|}
\hline \multirow{2}{*}{$\begin{array}{c}(\$ \text { in Millions })^{a} \\
(\text { Personnel in FTEs) }\end{array}$} & \multicolumn{2}{|c|}{ FY 1982} & \multicolumn{2}{|c|}{ FY 1983} & \multicolumn{2}{|c|}{ FY 1984} & \multicolumn{2}{|c|}{ FY 1985} & \multicolumn{2}{|c|}{ FY 1986} & \multicolumn{2}{|c|}{ FY 1987} & \multicolumn{2}{|c|}{ FY 1988} & \multicolumn{2}{|c|}{ FY 1989} \\
\hline & BA & $\mathrm{BO}$ & BA & BO & BA & $\mathrm{BO}$ & BA & BO & BA & BO & BA & BO & $\mathrm{BA}$ & BO & BA & BO \\
\hline Total Operating & 2.1 & 2.1 & 1.2 & 1.2 & 4.9 & 4.9 & 4.4 & 4.4 & 4.3 & 4.3 & 4.3 & 4.3 & 4.3 & 4.3 & 4.1 & 4.1 \\
\hline Capital Equipment & 0.0 & & 0.0 & & 0.0 & & 0.0 & & 0.0 & & 0.0 & & 0.0 & & 0.0 & \\
\hline Construction & 0.0 & & 0.0 & & 0.0 & & 0.0 & & 0.0 & & 0.0 & & 0.0 & & 0.0 & \\
\hline $\begin{array}{l}\text { Total for other } \\
\text { federal programs }\end{array}$ & 2.1 & 2.1 & 1.2 & 1.2 & 4.9 & 4.9 & 4.4 & 4.4 & 4.3 & 4.3 & 4.3 & 4.3 & 4.3 & 4.3 & 4.3 & 4.3 \\
\hline Direct Personnel & 17.0 & & 8.2 & & 26.1 & & 24.6 & & 23.9 & & 23.9 & & 23.9 & & 22.6 & \\
\hline
\end{tabular}

${ }^{a}$ An $8.5 \%$ inflation factor has been used between FY 1983 and FY 1984 and between FY 1984 and FY 1985. FY 1986-FY 1989 amounts are in constant FY 1985 dollars.

\section{NONFEDERAL ORGANIZATIONS}

\section{Electric Power Research Institute}

Research sponsored by EPRI addresses critical national issues related to electric power generation. Major efforts in this area are directed at understanding the processes and mechanisms by which acidic deposition of energy-related pollutants impact nutrient cycling and sulfur and nitrogen dynamics of forest ecosystems; at discriminating the relative importance and effects of wet and dry deposition of acidic substances in both forest and agricultural systems; and at characterizing the role of potentially toxic aluminum mobilization in streams. Also included are projects on the effects of acidic deposition on fisheries and lakes, studies of the role of cooling towers in the ecology of Legionnaires' disease, and reseach on instrumentation and controls related to improved safety and availability of LWR systems. The Laboratory expects to continue these or other programs for EPRI and anticipates that this funding will expand during the course of the planning cycle. 
EPRI Program resource summary

\begin{tabular}{|c|c|c|c|c|c|c|c|c|c|c|c|c|c|c|c|c|}
\hline \multirow{2}{*}{$\begin{array}{c}(\$ \text { in Millions })^{a} \\
\text { (Personnel in FTEs) }\end{array}$} & \multicolumn{2}{|c|}{ FY 1982} & \multicolumn{2}{|c|}{ FY 1983} & \multicolumn{2}{|c|}{ FY 1984} & \multicolumn{2}{|c|}{ FY 1985} & \multicolumn{2}{|c|}{ FY 1986} & \multicolumn{2}{|c|}{ FY 1987} & \multicolumn{2}{|c|}{ FY 1988} & \multicolumn{2}{|c|}{ FY 1989} \\
\hline & BA & BO & BA & BO & BA & BO & BA & BO & BA & BO & BA & BO & BA & BO & BA & BO \\
\hline Total Operating & 2.1 & 2.1 & 2.2 & 2.2 & 2.5 & 2.5 & 2.5 & 2.5 & 3.0 & 3.0 & 3.0 & 3.0 & 3.0 & 3.0 & 3.0 & 3.0 \\
\hline Capital Equipment & 0.0 & & 0.01 & & 0.01 & & 0.01 & & 0.02 & & 0.02 & & 0.02 & & 0.02 & \\
\hline Construction & 0.0 & & 0.0 & & 0.0 & & 0.0 & & 0.0 & & 0.0 & & 0.0 & & 0.0 & \\
\hline $\begin{array}{l}\text { Total for EPRI } \\
\text { programs }\end{array}$ & 2.1 & 2.1 & 2.2 & 2.2 & 2.5 & 2.5 & 2.5 & 2.5 & 3.0 & 3.0 & 3.0 & 3.0 & 3.0 & 3.0 & 3.0 & 3.0 \\
\hline Direct Personnel & 20.0 & & 13.0 & & 17.6 & & 17.0 & & 17.0 & & 17.0 & & 17.0 & & 17.0 & \\
\hline
\end{tabular}

${ }^{a}$ An $8.5 \%$ inflation factor has been used between FY 1983 and FY 1984 and between FY, 1984 and FY 1985. FY 1986-FY 1989 amounts are in constant FY 1985 dollars.

\section{Other Nonfederal Organizations}

ORNL's unique expertise in many research areas results in a number of small or short-term projects being performed for many different nonfederal organizations. Such activities are beneficial to, and do not interfere with, DOE-sponsored work. Currently, nonfederal sponsors include such entities as the United Kingdom's Atomic Energy Agency, JAERI, the Gas Research Institute, Metropolitan Edison/General Public Utility, the University of Tennessee, the Massachusetts General Hospital, the Florida Institute of Phosphate Research, Gulf Oil, and the General Electric Corporation. As a new activity for FY 1984, the ORNL Fusion Program will receive funds from the Joint European Torus (JET) program in Europe for conducting a beryllium-limiter experiment in the ISX-B tokamak. The total amount of funding which was derived from such sources for FY 1983 was about $\$ 1.0$ million.

Other Nonfederal Organizations Program resource summary

\begin{tabular}{|c|c|c|c|c|c|c|c|c|c|c|c|c|c|c|c|c|}
\hline \multirow{2}{*}{$\begin{array}{c}(\$ \text { in Millions })^{a} \\
\text { (Personnel in FTEs) }\end{array}$} & \multicolumn{2}{|c|}{ FY 1982} & \multicolumn{2}{|c|}{ FY 1983} & \multicolumn{2}{|c|}{ FY 1984} & \multicolumn{2}{|c|}{ FY 1985} & \multicolumn{2}{|c|}{ FY 1986} & \multicolumn{2}{|c|}{ FY 1987} & \multicolumn{2}{|c|}{ FY 1988} & \multicolumn{2}{|c|}{ FY 1989} \\
\hline & $\mathbf{B A}$ & BO & BA & BO & BA & BO & BA & BO & BA & BO & BA & $\mathrm{BO}$ & BA & BO & BA & BO \\
\hline Total Operating & 2.3 & 2.3 & 1.0 & 1.0 & 3.8 & 3.8 & 1.6 & 1.6 & 1.5 & 1.5 & 1.5 & 1.5 & 1.5 & 1.5 & 1.5 & 1.5 \\
\hline Capital Equipment & 0.0 & & 0.0 & & 0.02 & & 0.02 & & 0.02 & & 0.02 & & 0.02 & & 0.02 & \\
\hline Construction & 0.0 & & 0.0 & & 0.0 & & 0.0 & & 0.0 & & 0.0 & & 0.0 & & 0.0 & \\
\hline $\begin{array}{l}\text { Total for } \\
\text { nonfederal programs }\end{array}$ & 2.3 & 2.3 & 1.0 & 1.0 & 3.8 & 3.8 & 1.6 & 1.6 & 1.5 & 1.5 & 1.5 & 1.5 & 1.5 & 1.5 & 1.5 & 1.5 \\
\hline Direct Personnel & 18.5 & & 6.7 & & 20.0 & & 13.5 & & 12.9 & & 12.9 & & 12.9 & & 12.9 & \\
\hline
\end{tabular}

${ }^{a}$ An $8.5 \%$ inflation factor has been used between FY 1983 and FY 1984 and between FY 1984 and FY 1985. FY 1986FY 1989 amounts are in constant FY 1985 dollars. 
$-$

$\bullet$ 


\section{LABORATORY RESOURCE DEVELOPMENT}

DO NOT MOPOFLM in. THS PAGE 


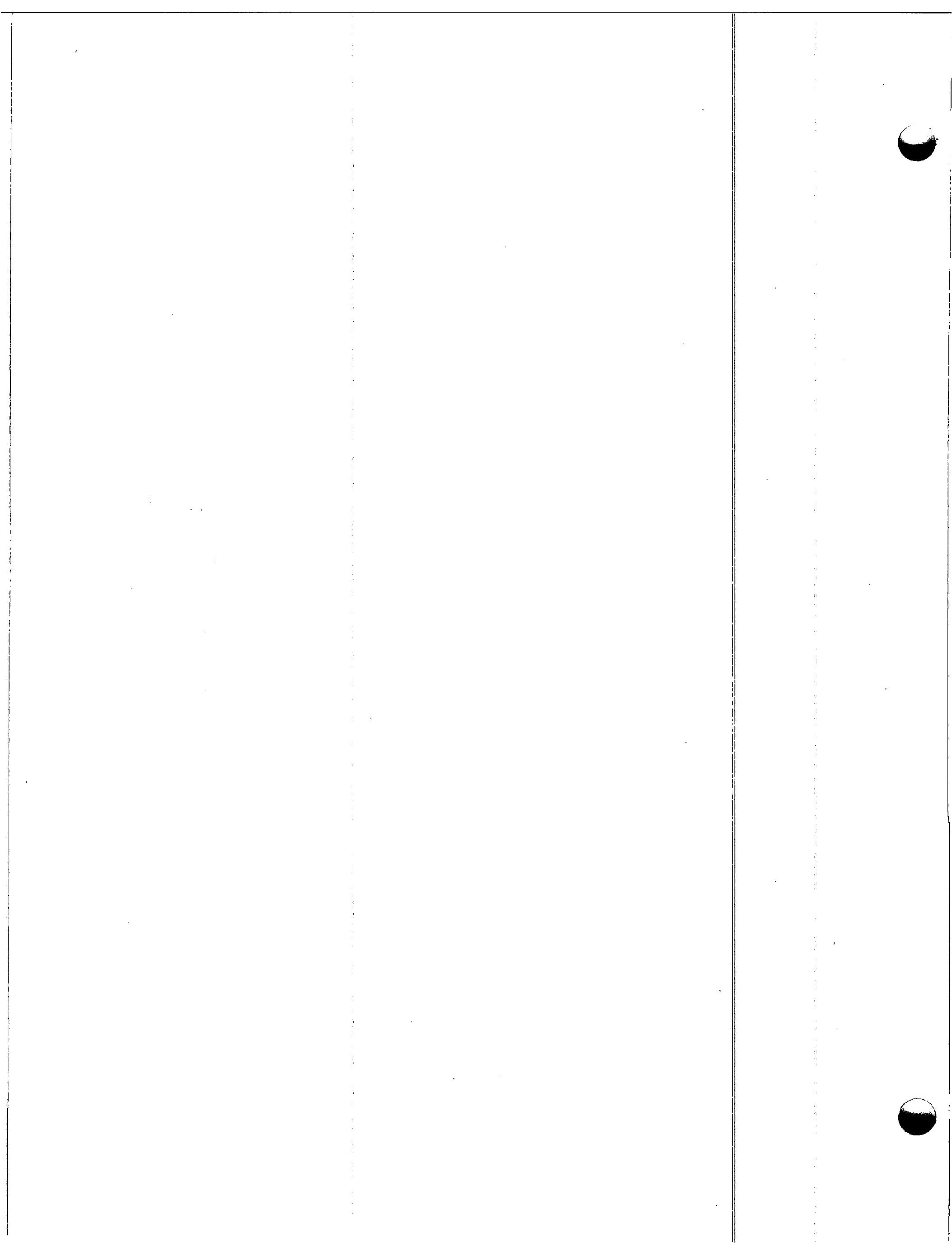




\section{LABORATORY RESOURCE DEVELOPMENT}

\section{PROGRAM TRENDS}

Figure 5 depicts the planned Laboratory effort in terms of direct personnel dedicated to assistantsecretary-level programs. Overall, the projections for the DOE programs can be generally described as indicating a virtually stable mix over the planning cycle. Variation, over time, is only a matter of 2 to $3 \%$ in any given program. The OER projection, for example, remains almost level at 43 or $44 \%$ of total direct FTEs for all years, while effort for ASNE is projected to increase slightly from about $14 \%$ to $17 \%$. The proportion of total direct FTEs supported by non-DOE sponsors is also expected to remain stable at about 21 or $22 \%$ of the total.

ORNL-DWG $83 \mathrm{C} \cdot 18324$

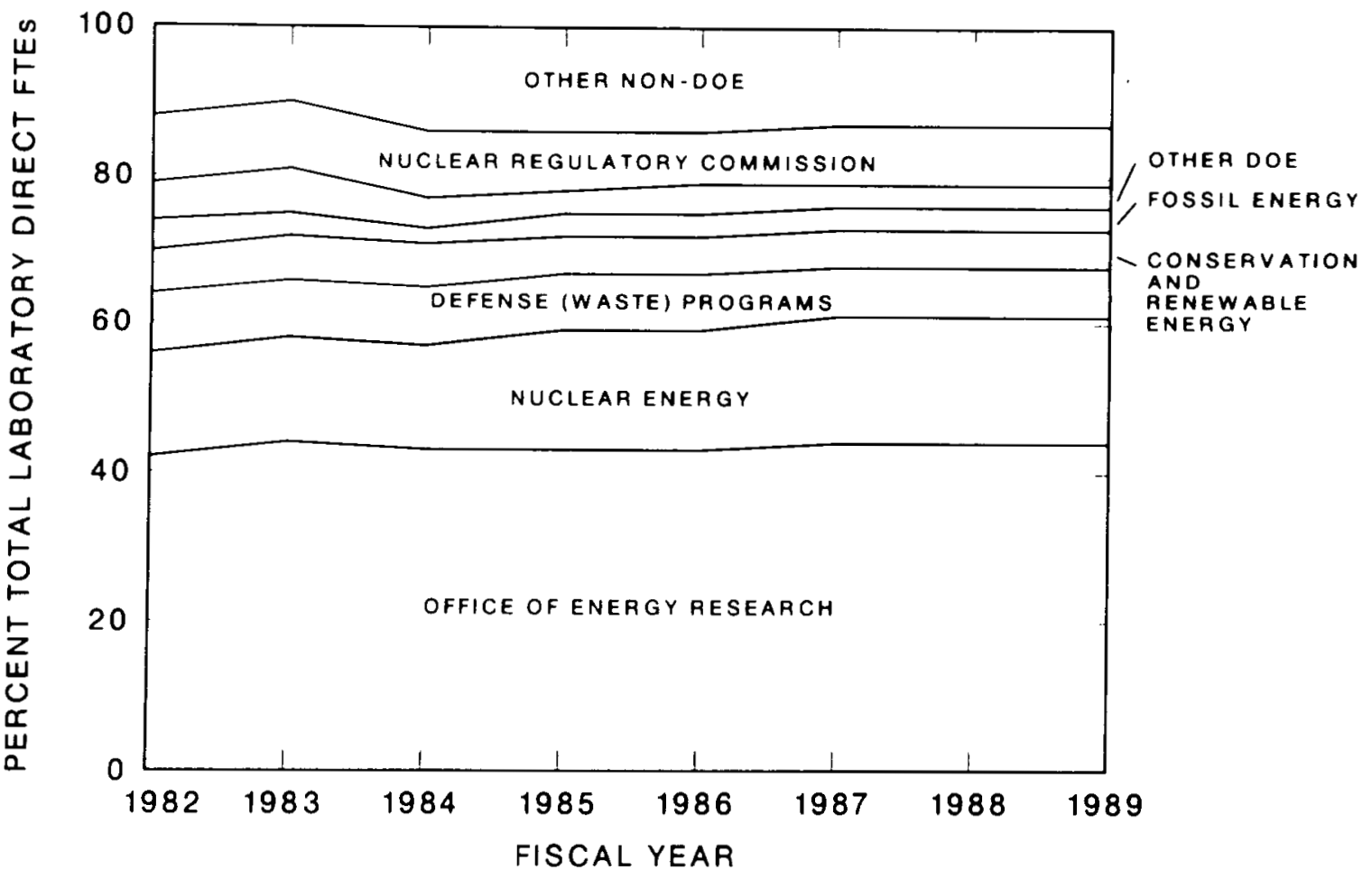

Fig. 5. Trends in Laboratory effort. 
The breakdown of the Work for Others component will, however, change somewhat more noticeably (Fig. 6). While the absolute amount of support from traditional sponsors such as NRC and DHHS is not expected to decrease, the predominant trend will nevertheless be toward modest decreases in their proportion of total Work for Others support. These decreases will be offset by an increase in effort devoted to work for DOD from roughly 13\% in FY 1983 to about $19 \%$ or $20 \%$ in the out years. The NRC will, nevertheless, remain our largest non-DOE sponsor--supporting a projected 38\% of non-DOE direct FTEs even in FY 1989.

OANL-DWG $83 C \cdot 18325$

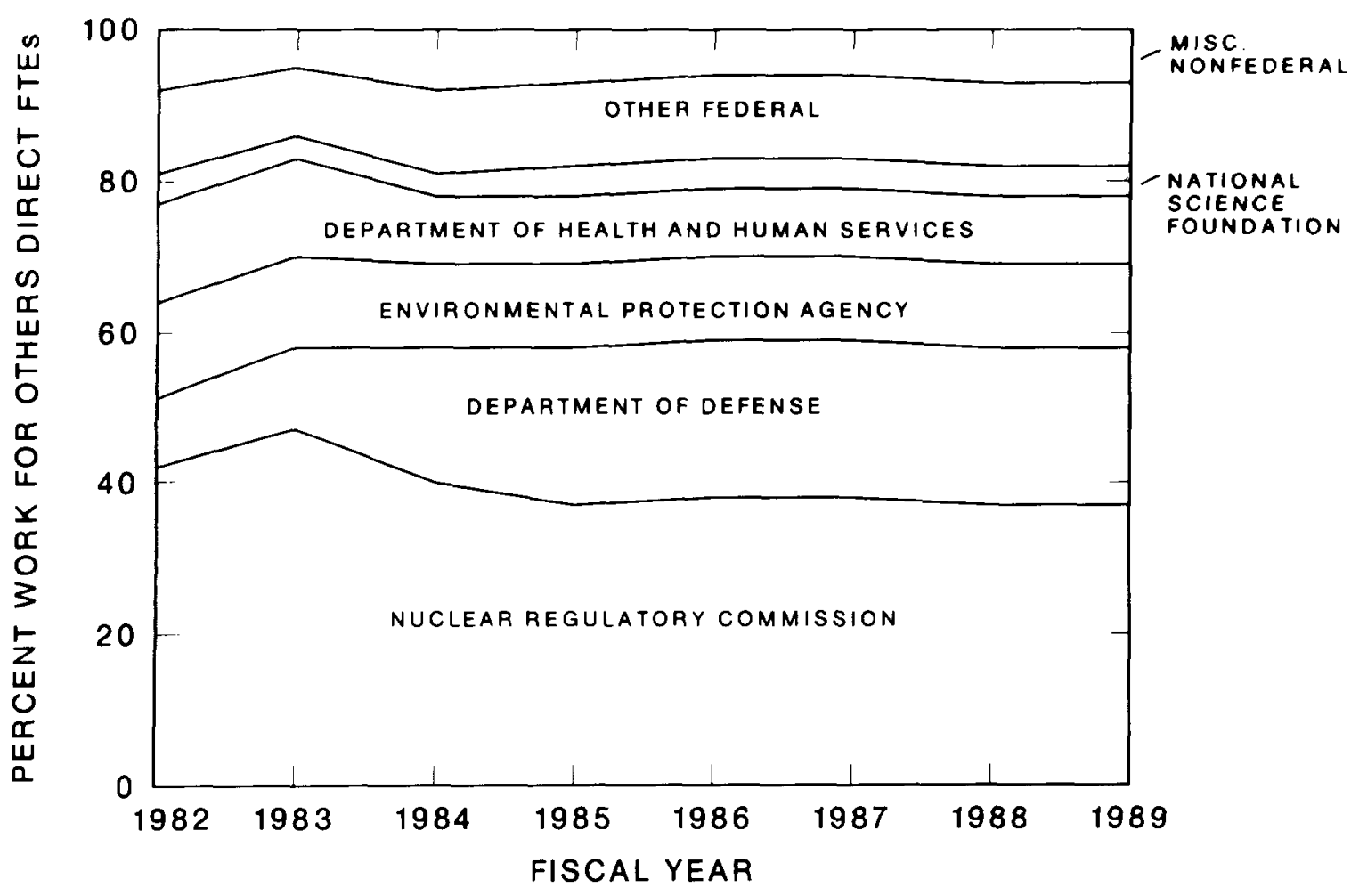

Fig. 6. Trends in Work for Others.

\section{PERSONNEL RESOURCES}

Figure 7 shows the overall trends in personnel levels from FY 1979 projected through FY 1989. Although peak employment at the Laboratory occurred in FY 1968, the total personnel levels of 1980 and 1981 prior to a reduction-in-force were also over 5000. The FY 1983 total of 4443 thus represents a substantial decrease in the Laboratory's labor force. Although some increase in personnel is projected over the planning cycle, growth will be modest. The total personnel projection for FY 1989 is only 4798 FTEs-well under the levels of 1980 and 1981. 
OANL-DWO 83C-18327

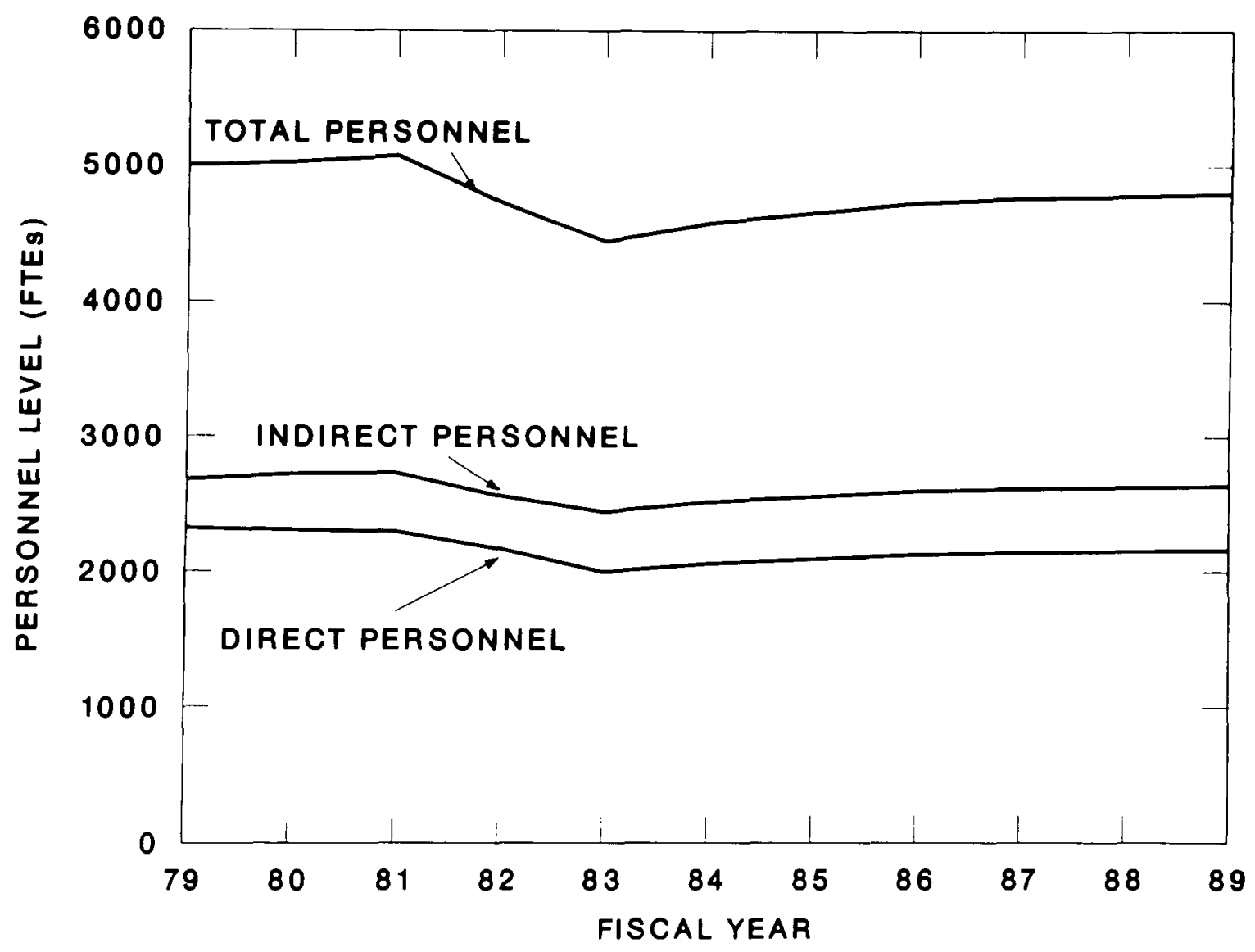

Fig. 7. Trends in personnel, levels, FY 1979-FY 1989.

\section{SITE DEVELOPMENT AND FACILITIES MANAGEMENT}

The goals of site development activities at ORNL during the next five years can be summarized as follows:

- provide for the efficient and reliable functioning of existing facilities,

- accommodate new program initiatives,

- review or replace age-deteriorated and obsolete facilities,

- improve utilization and eliminate overcrowding of existing facilities, and

- eliminate redundant and/or temporary facilities.

These five goals provide the basic framework and direction for ORNL's facilities planning. Implementation of these goals is a long-term project and will not be completed during the planning period but rather will require 10 to 20 years. The Site Development and Facilities Utilization Plan is currently being updated and will reflect an in-depth view of our five-point facilities planning strategy. 
One of the most important elements of the current Site Development Plan concerns the future of ORNL facilities at Y-12. Currently, it is ORNL's intention to make the following major changes. The Fusion Energy and Engineering Technology divisions' activities will continue to be located at Y-12. Centralization of Fusion Energy and Engineering Technology will focus on Buildings 9201-3 and 9201-2 - as funding permits. Again, depending upon available funding, the Biology Division will be relocated to the X-10 site in a phased manner over a 10-15-year period. The existing Biology Division buildings are not required in the long term for other ORNL activities and will ultimately be transferred back to Y-12 for reuse or demolition. The joint use of Building 9204-3 between ORNL's isotope activities and compatible Y-12 activities will take place as appropriate Y-12 programs are funded. ORNL's near-term consolidation efforts may permit the transfer of some existing space in scattered locations back to $Y-12$. In the future, no new ORNL programs will be located at the $\mathrm{Y}-12$ site, unless absolutely necessary.

A deficit of adequate office/light laboratory space exists at ORNL while a surplus of offices and laboratories (light and heavy) exists in selected Y-12 facilities. Thus, while an adequate amount of total space exists to satisfy current and planned missions, not all of this existing space can be utilized cost effectively to satisfy our needs. Remote offices and laboratories at Y-12 cannot be used cost effectively by ORNL to solve its space deficit because such use would severely fragment user groups and reduce their functional effectiveness.

In the long run (10-20 years), the total space at ORNL is expected to decline by about $600,000 \mathrm{ft}^{2}$ to a total of about $3,400,000 \mathrm{ft}^{2}$. The decommissioning of inactive experimental reactors, the transfer of redundant space at Y-12, the demolition of selected small structures, and the consolidations and retirements of obsolete structures made possible through the construction of the line-item projects proposed in this plan will provide the means to implement this reduction.

\section{Multiprogram General Purpose Facilities (MGPF)}

The MGPF program at ORNL addresses those facilities-restoration projects that are beyond the scope of GPP. These projects focus primarily on badly needed utility system upgrades and obsolete building rehabilitation or replacement. Projects proposed for FY 1985 include the Primary Electrical Distribution System Restoration, which will improve the reliability, flexibility, and efficiency of the electrical system, particularly those portions of it which are deficient; the Central Chilled Water System Restoration; the Environmental Monitoring System Upgrade-Phase I, which will also provide efficient and reliable functioning of existing facilities; and the Fire Protection Upgrade at Y-12, which would replace obsolete systems and extend coverage into areas which still require protection.

Several projects are also proposed for FY 1986. The Utilities Restoration-Piping Systems Phase I for ORNL at Y-12 would replace key elements of various worn-out piping systems. The evaluation study of the Steam Distribution System noted significant deterioration of some parts of the current underground system. At the same time, another preliminary study indicated a significant potential energy savings from conversion to a hot water system for space heating. The two studies have determined that conversion to a district hot water system is more cost effective than the restoration of the steam system. A project for this conversion is therefore being proposed. 
Other proposed projects for FY 1986 are the Central Administrative and Support Building, which will virtually eliminate the office overcrowding in the main research complex, and Phase II of the Environmental Monitoring System Upgrade, which will install added capabilities to enable the Laboratory to conform to current criteria. A summary of MGPF projects is provided in Table 15.

Table 15. MGPF project summary

\begin{tabular}{|c|c|c|c|c|c|c|c|c|}
\hline Title & 1983 & 1984 & 1985 & 1986 & 1987 & 1988 & 1989 & TEC \\
\hline \multicolumn{9}{|c|}{ Multiprogram General Purpose Facilities (KG) } \\
\hline \multicolumn{9}{|l|}{ Funded projects } \\
\hline $\begin{array}{l}\text { Laboratory Emergency Response } \\
\text { Center }\end{array}$ & 2.0 & 2.2 & & & & & & 4.2 \\
\hline $\begin{array}{l}\text { Upgrade Electrical Service for } \\
\text { Research Facilities }(Y-12)\end{array}$ & 1.6 & 2.5 & 0.9 & & & & & 5.0 \\
\hline Total funded projects & 3.6 & 4.7 & 0.9 & & & & & \\
\hline \multicolumn{9}{|l|}{ Budgeted projects } \\
\hline $\begin{array}{l}\text { Cooling Water Facilities } \\
\text { Restoration }(Y-12)\end{array}$ & & 0.6 & 2.0 & 1.4 & & & & 4.0 \\
\hline $\begin{array}{l}\text { Improvements to Existing Sewage } \\
\text { Treatment System }\end{array}$ & & 1.2 & & & & & & 1.2 \\
\hline Total budgeted projects & & 1.8 & & & & & & \\
\hline \multicolumn{9}{|l|}{ Proposed projects } \\
\hline $\begin{array}{l}\text { Environmental Monitoring System } \\
\text { Upgrade, Phase I }\end{array}$ & & & 1.0 & 2.5 & & & & 3.5 \\
\hline $\begin{array}{l}\text { Primary Electrical Distribution } \\
\text { System Restoration }\end{array}$ & & & 0.4 & 1.8 & & & & 2.2 \\
\hline $\begin{array}{l}\text { Central Chilled-Water System } \\
\text { Restoration }\end{array}$ & & & 1.1 & 3.6 & & & & 4.7 \\
\hline $\begin{array}{l}\text { Upgrade Fire Protection-ORNL facilities } \\
\text { at } Y-12\end{array}$ & & & 0.4 & 1.4 & & & & 1.8 \\
\hline $\begin{array}{l}\text { Utilities Restoration-Piping } \\
\text { Systems, Phase I }(Y-12)\end{array}$ & & & 1.1 & 3.6 & 3.6 & & & 8.3 \\
\hline $\begin{array}{l}\text { Laboratory Hot-Water District Heating } \\
\text { System (formerly Upgrade Steam } \\
\text { Distribution System) }\end{array}$ & & & & 1.8 & 4.7 & & & 6.5 \\
\hline $\begin{array}{l}\text { Central Administrative and } \\
\text { Support Building }\end{array}$ & & & & 1.0 & 4.5 & & & 5.5 \\
\hline $\begin{array}{l}\text { Environmental Monitoring Systems Upgrade, } \\
\text { Phase II }\end{array}$ & & & & 1.0 & 4.0 & & & 5.0 \\
\hline Bioscience and Technology Facility & & & & & 25.0 & & & 25.0 \\
\hline $\begin{array}{l}\text { Utilities Restoration-Electrical } \\
\text { Systems, Phase I (Y-12) }\end{array}$ & & & & & 4.0 & & & 4.0 \\
\hline $\begin{array}{l}\text { Electrical Distribution } \\
\text { System Upgrade }\end{array}$ & & & & & 1.5 & & & 1.5 \\
\hline $\begin{array}{l}\text { Street System Rehabilitation } \\
\text { and Additions }\end{array}$ & & & & & & 5.0 & & 5.0 \\
\hline Existing Laboratories Upgrade & & & & & & 10.0 & & 10.0 \\
\hline $\begin{array}{l}\text { Utilities Restoration-Mechanical } \\
\text { Systems, Phase I (Y-12) }\end{array}$ & & & & & & 4.0 & & 4.0 \\
\hline Technical Support Facility & & & & & & 15.0 & & 15.0 \\
\hline Support Facilities Upgrade & & & & & & & 10.0 & 10.0 \\
\hline $\begin{array}{l}\text { Utilities Restoration-Piping } \\
\text { Systems, Phase II }(\mathrm{Y}-12)\end{array}$ & & & & & & & 4.0 & 4.0 \\
\hline $\begin{array}{l}\text { Existing Laboratory/Office } \\
\text { Upgrade }\end{array}$ & & & - & - & $\square$ & 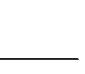 & 13.0 & 13.0 \\
\hline Total proposed projects & & & 6.0 & 18.1 & 47.4 & 34.0 & 27.0 & \\
\hline
\end{tabular}




\section{General Plant Projects}

The past lack of GPP funding, coupled with a lack of line-item funding, has resulted in the development of a significant backlog of facilities deficiencies. The updated MGPF inventory of deficiencies indicates that the Laboratory faces a backlog of deficiencies of approximately $\$ 200$ million. Not all of these deficiencies are, however, most logically corrected with GPP funds. It is estimated that at least $\$ 150$ million should receive line-item support, which means that the GPP backlog of general purpose facilities deficiencies is about $\$ 50$ million. The deficiencies identified by additional Facilities Evaluations now under way, while differing in some cases from the MGPF Inventory of Deficiencies, do produce proposed corrective measures with costs in the same general range as the previously developed proposed corrective measures. These more highly focused studies will continue to refine and prioritize essential needs as they are completed. The Laboratory believes, however, that these Facilities Evaluations will only confirm that there are significant needs in basic systems. For this reason, the Laboratory continues to project the need for substantial increases in GPP funding.

The $\$ 9$ million for FY 1985 indicated in the following table reflects immediate needs for pressing environmental concerns. The $\$ 14$ million shown in FY 1986 starts the ramp upward toward a peak of $\$ 21$ million in FY 1988. Based on the programmatic projections of each yearly total during the planning period, about $\$ 6$ million should be used to support program requirements. The remaining $\$ 8$ to 15 million would address the deficiencies identified in our evaluations.

GPP

\begin{tabular}{lcccccccc}
\hline (\$ in Millions-BA) & FY 1982 & FY 1983 & FY 1984 & FY 1985 & FY 1986 & FY 1987 & FY 1988 & FY 1989 \\
\hline $\begin{array}{l}\text { General Laboratory } \\
\text { GPP (AT Program) } \\
\begin{array}{c}\text { Waste Management } \\
\text { (AR Program) }\end{array}\end{array}$ & 4.3 & 3.5 & 4.2 & 9.0 & 14.0 & 20.0 & 21.0 & 21.0 \\
$\begin{array}{c}\text { Energy Conservation } \\
\text { (WB Program) }\end{array}$ & 0.7 & 1.5 & 2.0 & 2.0 & 2.0 & 2.0 & 1.5 & 1.0 \\
$\quad \begin{array}{l}\text { Total GPP } \\
\text { funding }\end{array}$ & 5.8 & 7.0 & 8.0 & 10.5 & 18.5 & 24.5 & 25.0 & 24.5 \\
\hline
\end{tabular}

\section{General Purpose Equipment}

The funding for GPE has increased in recent years, but the increased levels have not been sufficient to meet new requirements as well as replacement of worn out equipment. Increased emphasis on accuracy and improved productivity and efficiency has made the acquisition of state-of-the-art equipment essential for supporting ongoing and new research activities. Because of the age of much of ORNL's capital equipment inventory, more than half of the GPE funding received annually must now be used to replace failed and worn-out equipment. An analysis of the current GPE inventory has revealed that of the $\$ 40.4$ million invested, $\$ 16.7$ million, or $41 \%$, is older than design liftimes by current accounting standards. The details of the analysis are shown in Table 16. Based on the U.S. Department of Labor's Producer Price Index for May 1983, the $\$ 16.7$ million of aged equipment would require about $\$ 50$ million for replacement based on 1983 dollars. 
Table 16. Summary of aged GPE

( $\$$ in Thousands)

\begin{tabular}{|c|c|c|c|c|c|}
\hline $\begin{array}{l}\text { Asset } \\
\text { class }\end{array}$ & Description & $\begin{array}{l}\text { Average design } \\
\text { lifetime } \\
\text { (years) }\end{array}$ & $\begin{array}{c}\text { Original } \\
\text { purchase cost }\end{array}$ & $\begin{array}{c}\text { Original } \\
\text { cost of } \\
\text { items exceeding } \\
\text { design lifetime }\end{array}$ & $\begin{array}{l}\text { Percent equipment } \\
\text { exceeding design lifetime }\end{array}$ \\
\hline 710 & Heavy mobile equipment & 12 & $\$ 1,785$ & $\$ 785$ & 44.0 \\
\hline 715 & Hospital and medical & 12 & 105 & 33 & 31.4 \\
\hline 720 & Laboratory equipment & 15 & 12,066 & 6,000 & 49.7 \\
\hline 725 & Motor vehicles & 10 & 4,555 & 1,500 & 32.9 \\
\hline 730 & $\begin{array}{l}\text { Office furniture and } \\
\text { equipment }\end{array}$ & 10 & 1,817 & 345 & 19.0 \\
\hline 735 & Process equipment & 20 & 1,581 & 1,000 & 63.3 \\
\hline 755 & Shop equipment & 20 & 6,089 & 3,750 & 61.6 \\
\hline 770 & $\begin{array}{l}\text { Automated data processing } \\
\text { and word processing } \\
\text { equipment }\end{array}$ & 7 & 11,180 & 3,000 & 26.8 \\
\hline \multirow[t]{2}{*}{770} & Miscellaneous equipment & 13 & 1,194 & 250 & 20.9 \\
\hline & Total & & $\$ 40,372$ & $\$ 16,663$ & 41.3 \\
\hline
\end{tabular}

${ }^{a}$ Replacement cost is approximately three times original cost ( $\$ 50$ million) in FY 1983 dollars.

In order to maintain an acceptable rate of new equipment additions and replacement of obsolete equipment, an annual base budget level of $\$ 6$ million should be maintained for the former while some additional funding of $\$ 8 \mathrm{M} / \mathrm{yr}$ over 12-13 years will be required for the latter. (Table 1 listing GPE for the years of the planning cycle, does not, however, reflect such necessary increases. Rather, only modest increases over the base budget are listed for the out years.)

The particular areas that will continue to require significant amounts of new GPE funds include small computers for budgeting and other purposes; fuel-conserving vehicles; instruments for analytical chemistry support services; satellite dishes for computer hook-ups; and computer-aided drafting and computer-aided manufacturing (CAD/CAM). Additionally, the impact of strict compliance with local, state, and national environmental regulations has not been fully assessed in terms of additional GPE, but it is expected to be significant as it is for GPP and MGPF. 
-

$\bullet$ 


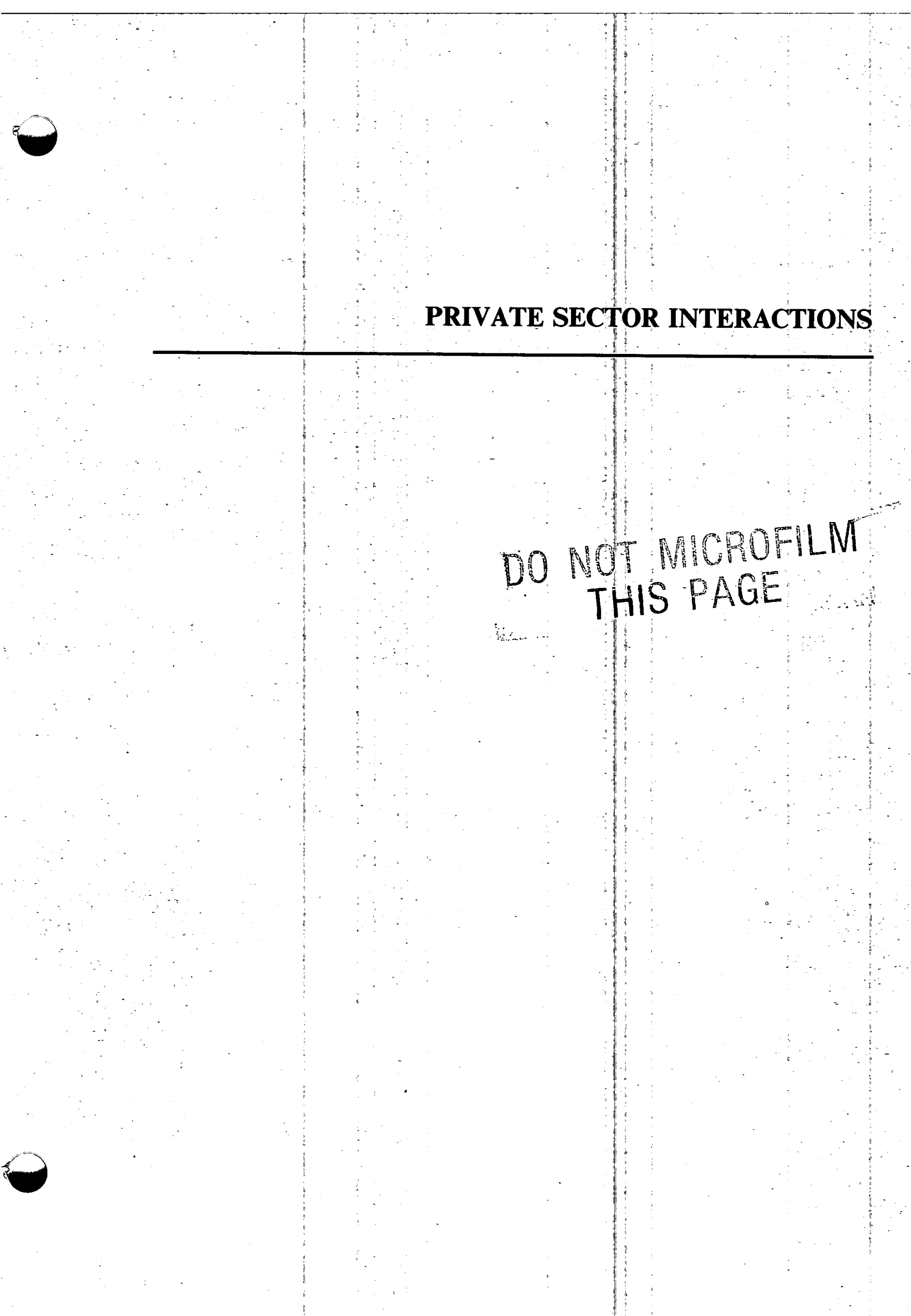




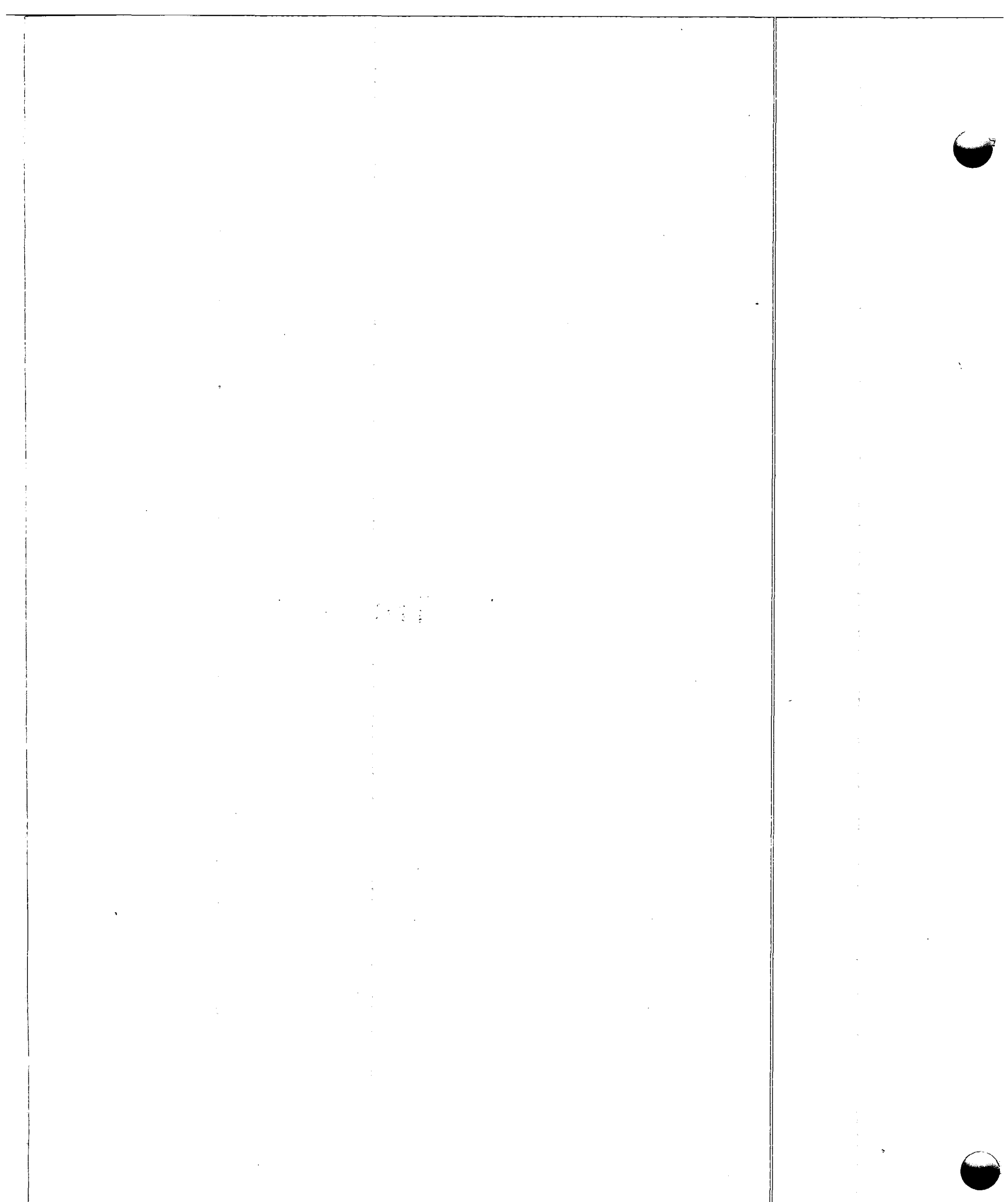




\section{PRIVATE SECTOR INTERACTIONS}

\section{TECHNOLOGY TRANSFER PROGRAM}

\section{Overview of Existing Program}

ORNL has had a Technology Transfer Program for 13 years. The Office of Research and Technology Applications (ORTA) now reports to the Executive Director and has one full-time professional staff member. Laboratory-wide activities are coordinated through 21 part-time Division and Program Technology Transfer officers (Fig. 8). Funding for the Program Office is from overhead; however, most technology transfer activities at the Laboratory are funded from the individual programs.

ORNL-DWG $83 \mathrm{C}-18323$

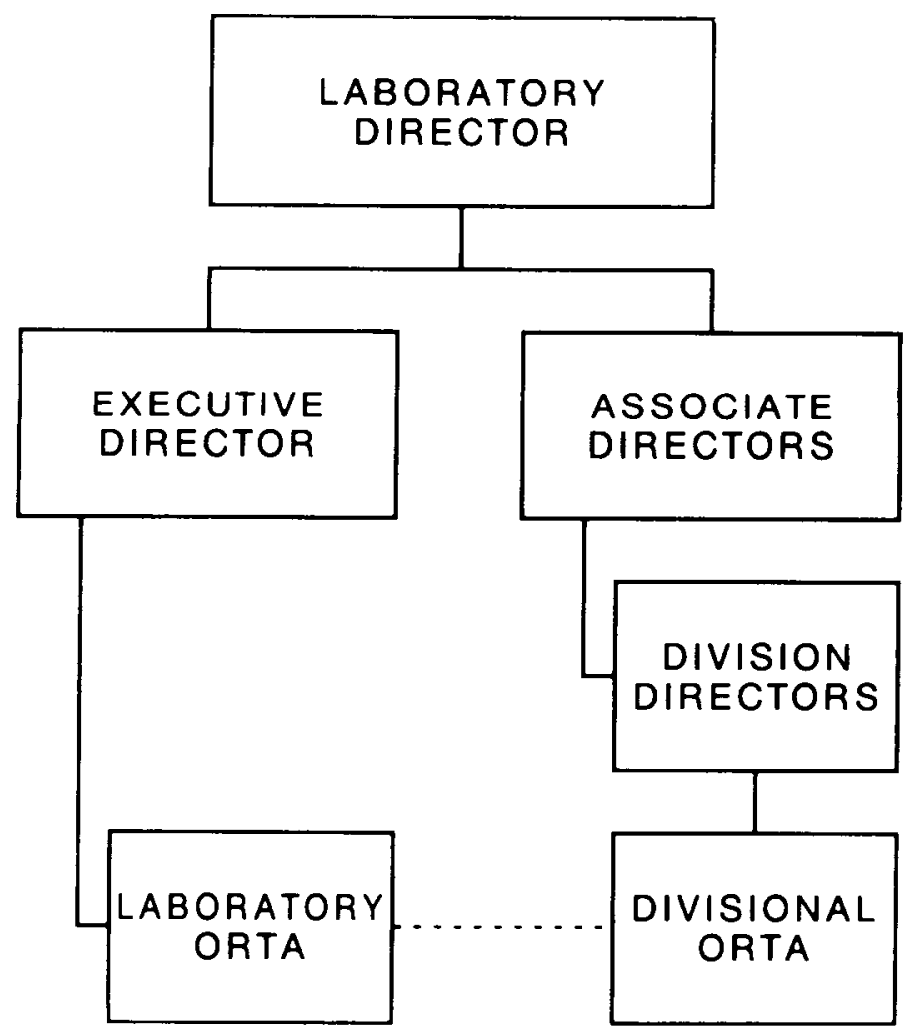

Fig. 8. Organizational makeup and reporting level of ORNL's ORTA. 
Major activities of the Technology Transfer Program include developing technology assessments, disseminating information, cooperating with broker organizations, and furnishing assistance to state and local government officials as required by the Stevenson-Wydler Technology Innovation Act. Since the office was established, 250 Technology Applications Bulletins have been published and some 14,000 requests for additional information have been received. An independent study indicated that $27 \%$ of these requestors used the information provided.

\section{Proposed Expanded Activities: New Initiative on Industrial Technology}

It is generally acknowledged that technical innovation is the key to the nation's economic future. For this reason, the links between generators and users of new knowledge must be strengthened. The focus of the Stevenson-Wydler Technology Innovation Act of 1980 was to help build the needed links between R\&D performers and users. The Act was intended to provide a means of strengthening the relationships among government, industry, and academia so that each sector might contribute to the innovation process in a program of shared responsibilities. Major elements planned as means to accomplish the purposes of the Act include: (1) promoting technology development through the establishment of centers for Industrial Technology; (2) stimulating improved utilization of federally funded technology developments; and (3) encouraging the exchange of scientific and technical personnel among academia, industry, and the federal laboratories.

ORNL proposes a new initiative directed toward improving the Laboratory's effectiveness in contributing to the national goal of renewing the country's industrial base. The objectives of the new initiative are to (1) improve the rate of innovation at the Laboratory and (2) increase the frequency of effective transfer of technological innovations to the private sector. To accomplish these objectives, the scope and level of technology-transfer activities at ORNL will be substantially increased. No role model exists on which to base a successful technology transfer program. Thus, no grand concept is proposed at this time; experimentation with several relatively small, specific activities seems more appropriate. Nevertheless, at some future time, we would like to see the industrial technology activities expand to include a Center for Industrial Technology as envisioned in the Stevenson-Wydler Act. Among other activities, such a Center would provide the means for combining the ideas, talents, and industrial research capabilities of regional universities with the facilities of a national laboratory.

Specific activities proposed at this time are as follows:

1. Strengthen Motivation for Technology Transfer. The effectiveness of technology transfer activities at ORNL can be improved by increasing the incentives for the institution and for individual staff members. Specific ideas for improving the motivation for innovation and technology transfer have recently been discussed by ORO and ORNL. These ideas involve increased incentives for patent applications and easing of constraints on consulting by ORNL staff.

2. Exchange Research Personnel With Industry. People-to-people exchanges are the most effective means of technology transfer. A formal program that fosters the exchange of research personnel between ORNL and interested industrial firms will be established. 
3. Promote User Facilities. Greater promotional effort to increase industrial utilization of user facilities will be made. Activities will include (1) identification of potential users for each facility, (2) "open-house" familiarization tours for potential industrial users, and (3) development of improved literature on facilities, including a summary document covering all user facilities at ORNL.

4. Identify and Promote Promising Developments. An improved program will be established to promote the transfer of promising technologies and techniques from ORNL to the private sector. The program will consist of two elements: (1) identifying ORNL developments that have the most promise for commercial applications and (2) funding of additional R\&D or other activities necessary to bring the development to a state where industry can make an assessment of its true commercial potential. Examples of activities that may be supported are the preparation of materials samples for industry evaluation or the construction of prototypic instruments for industrial testing. Decisions about which developments to push will be made by the Director of ORNL based on advice from an Advisory Board on Industrial Technology. This board will consist mostly of people from industry but will also have representatives from DOE, academia, and ORNL. Members will be selected based on their degree of knowledge about the broad needs of industry and about the means by which new technologies are commercialized. Once a promising development has been identified, the further activities needed to make commercial judgements will be guided by advice from industry specialists. For the first year or so, the program will be a pilot-scale activity and will emphasize materials sciences.

Implementation of the proposed expanded activities will entail some additional costs. ORNL proposes that an additional $\$ 500,000$ annually be provided-one-half from ORNL overhead and one-half new funding from DOE. The following table (Table 17) of estimated staffing and expenditures reflects this expansion of ORTA funding.

Table 17. Estimated stafring and funding

\begin{tabular}{|c|c|c|c|c|c|c|c|c|}
\hline & FY 1982 & FY 1983 & FY 1984 & FY 1985 & FY 1986 & FY 1987 & FY 1988 & FY 1989 \\
\hline \multicolumn{9}{|c|}{ Staffing (FTEs) } \\
\hline Professional Staff & & & & & & & & \\
\hline ORTA & 2 & 2 & 2 & 2 & 2 & 2 & 2 & 2 \\
\hline Other (Estimate) & 60 & 60 & 60 & 60 & 60 & 60 & 60 & 60 \\
\hline Total Staff & 62 & 62 & 62 & 62 & 62 & 62 & 62 & 62 \\
\hline Support Staff & 1 & 1 & 1 & 1 & 1 & 1 & 1 & 1 \\
\hline \multicolumn{9}{|c|}{ Funding ( $\$$ in thousands) } \\
\hline ORTA & 67 & 74 & 580 & 626 & 626 & 626 & 62 & 62 \\
\hline Other & 10,600 & 9,700 & 10,500 & 11,400 & 11,400 & 11,400 & 11,400 & 11,400 \\
\hline Total funding & 10,700 & 9,800 & 11,080 & 12,026 & 12,026 & 12,026 & 12,026 & 12,026 \\
\hline
\end{tabular}

${ }^{a}$ An $8.5 \%$ inflation factor has been used between FY 1983 and FY 1984 and between FY 1984 and FY 1985. FY 1986-FY 1989 amounts are in constant FY 1985 dollars.

\section{LABORATORY COLLABORATIVE RESEARCH CENTERS}

ORNL operates many large experimental facilities that are used extensively by both universities and industry. More than 100 universities and over 20 industrial firms have used these unique research resources. Use of the facilities by outside institutions is increasing, and major increases 
among industrial users are expected as the capabilities of some of the newer facilities receive more publicity. Table 18 describes the extent to which each facility is used by ORNL and other institutions.

Table 18. ORNL user facility participation

\begin{tabular}{|c|c|c|c|c|c|c|}
\hline & FY 1978 & FY 1979 & FY 1980 & FY 1981 & FY 1982 & FY 1983 \\
\hline \multicolumn{7}{|c|}{ EN-Tandem Van de Graaff Accelerator } \\
\hline \multicolumn{7}{|l|}{ Experimenter personnel } \\
\hline University & 20 & 20 & 20 & 20 & 20 & 16 \\
\hline ORNL & 1.5 & 1.5 & 1.5 & 1.5 & 1.6 & 1.6 \\
\hline \multicolumn{7}{|l|}{ Use ratio, $\%$} \\
\hline University & 25 & 25 & 25 & 25 & 25 & 25 \\
\hline ORNL & 75 & 75 & 75 & 75 & 75 & 75 \\
\hline $\begin{array}{l}\text { Total operating cost, } \\
\text { millions of dollars }\end{array}$ & 0.14 & 0.15 & 0.16 & 0.18 & 0.20 & 0.22 \\
\hline
\end{tabular}

Oak Ridge Electron Linear Accelerator

Experimenter personnel

University

Industry

ORNL

Other national laboratories

Others

Use ratio, \%

University

Industry

ORNL

Other national laboratories

Total operating cost,

millions of dollars

$\begin{array}{rrrrrr}8 & 8 & 8 & 8 & 10 & 10 \\ 5 & 5 & 5 & 5 & 5 & 3 \\ 14 & 14 & 14 & 14 & 14 & 12 \\ 3 & 3 & 3 & 3 & 3 & 2 \\ 2 & 2 & 2 & 2 & 2 & 5 \\ 9 & 9 & 9 & 9 & 9 & 11 \\ 5 & 5 & 5 & 5 & 5 & 3 \\ 85 & 85 & 85 & 85 & 85 & 85 \\ 1 & 1 & 1 & 1 & 1 & 1 \\ 1.0 & 1.1 & 1.2 & 1.3 & 1.4 & 1.5\end{array}$

University Isotope Separator (UNISOR)“

Experimenter pesonnel

University

ORNL

Other national laboratories

Others

Use ratio, \%

University

ORNL

Other national laboratories

Others

Total operating cost,

millions of dollars

$\begin{array}{rrrrrc}19 & 21 & 16 & 20 & 17 & 20 \\ 1 & 3 & 2 & 2 & 2 & 1 \\ 2 & 3 & 1 & 3 & 0 & 2 \\ 4 & 3 & 4 & 5 & 5 & 5 \\ 78 & 73 & 75 & 82 & 68 & 70 \\ 5 & 17 & 8 & 3 & 19 & 9 \\ 14 & 4 & 0 & 5 & 0 & 3 \\ 3 & 6 & 17 & 10 & 13 & 18 \\ 0.20 & 0.21 & 0.27 & 0.36 & 0.40 & 0.40\end{array}$

Experimenter personnel

University

Industry

ORNL

Other national laboratories

Shared Research Equipment

Others

Use ratio, \%

University

Industry

ORNL

Other national laboratories

Others

Total operating cost, millions of dollars

$\begin{array}{lrrrr}20 & 20 & 20 & 40 & 20 \\ & 3 & 6 & 6 & 6 \\ 3 & 6 & 7 & 7 & 10 \\ & & 1 & 1 & \\ & & 1 & 1 & \\ 15 & 20 & 23 & 23 & 23 \\ 85 & 3 & 5 & 5 & 5 \\ & 77 & 72 & 72 & 72 \\ & & & & \\ 0.40 & 0.45 & 0.50 & 0.50 & 0.50\end{array}$


Table 18 (continued)

\begin{tabular}{|c|c|c|c|c|c|}
\hline & FY 1978 FY 1979 & FY 1980 & FY 1981 & FY 1982 & FY 1983 \\
\hline \multicolumn{6}{|c|}{ Oak Ridge National Environmental Research Park } \\
\hline \multicolumn{6}{|l|}{ Experimenter personnel } \\
\hline University & & 1 & 0 & 2 & 1 \\
\hline ORNL & & 10 & 12 & 15 & 15 \\
\hline Others & & 4 & 13 & 11 & 7 \\
\hline \multicolumn{6}{|l|}{ Use ratio, $\%$} \\
\hline University & & 0.5 & 0 & 2 & 1 \\
\hline ORNL & & 90.5 & 89 & 96 & 96.5 \\
\hline Others & & 9 & 11 & 2 & 2.5 \\
\hline $\begin{array}{l}\text { Total operating cost, } \\
\text { millions of dollars }\end{array}$ & & 0.141 & 0.123 & 0.123 & 0.120 \\
\hline \multicolumn{6}{|c|}{ National Center for Small-Angle Scattering Research } \\
\hline \multicolumn{6}{|l|}{ Experimenter personnel } \\
\hline University & & & 80 & 100 & 72 \\
\hline Industry & & & 15 & 20 & 15 \\
\hline ORNL & & & 0.7 & 3.2 & 20 \\
\hline Other national laboratories & & & 6 & 6 & 0 \\
\hline Others & & & 4 & 4 & 9 \\
\hline \multicolumn{6}{|l|}{ Use ratio, \% } \\
\hline University & & & 85 & 85 & 85 \\
\hline Industry & & & 10 & 10 & 8 \\
\hline ORNL & & & 5 & 5 & 7 \\
\hline Other national Laboratories & & & $<5$ & $<5$ & $<5$ \\
\hline Total operating cost, & & & 0.15 & 0.58 & 0.62 \\
\hline
\end{tabular}

Holifield Heavy Ion Research Facility

Experimenter personnel

University

Industry

ORNL

Other national laboratories

Others

Use ratio, \%

University

Industry

ORNL

Other national laboratories

Others

Total operating cost,

millions of dollars

$\begin{array}{rrr}60 & 65 & 87 \\ 1 & 0 & 3 \\ 22 & 22 & 45 \\ 10 & 12 & 21 \\ 20 & 20 & 0 \\ & & \\ 36 & 36 & 44 \\ <1 & & <1 \\ 60 & 60 & 50 \\ 4 & 4 & 6 \\ <1 & <1 & <1 \\ 2.5 & 2.8 & 3.4\end{array}$

Surface Modification Laboratory

Experimenter personnel

University

Industry

ORNL

Others

Use ratio, \%

University

Industry

ORNL

Others

Total operating cost, millions of dollars

$\begin{array}{ccc}10 & 12 & 15 \\ 8 & 10 & 11 \\ 7 & 9 & 28 \\ 3 & 3 & 11 \\ & & \\ 15 & 15 & 16 \\ 20 & 20 & 12 \\ 65 & 65 & 60 \\ -1 & -1 & 12 \\ 0.8 & 0.9 & 1.2\end{array}$


Table 18 (continued)

\begin{tabular}{|c|c|c|c|c|c|c|}
\hline & FY 1978 & FY 1979 & FY 1980 & FY 1981 & FY 1982 & FY 1983 \\
\hline \multicolumn{7}{|c|}{ Neutron Scattering Facilities } \\
\hline \multicolumn{7}{|l|}{ Experimenter personnel } \\
\hline University & & 3 & 8 & 13 & 19 & 20 \\
\hline Industry & & 0 & 0 & 0 & 0 & 1 \\
\hline ORNL & & 12 & 16 & 13 & 14 & 15 \\
\hline Other national laboratories & & 4 & 8 & 8 & 7 & 6 \\
\hline Others & & 5 & 7 & 6 & 6 & 17 \\
\hline \multicolumn{7}{|l|}{ Use ratio, \% } \\
\hline University & & 7 & 10 & 17 & 23 & 21 \\
\hline Industry & & 0 & 0 & 0 & 0 & 1 \\
\hline ORNL & & 75 & 71 & 65 & 61 & 55 \\
\hline Other national laboratories & & 8 & 10 & 10 & 9 & 6 \\
\hline Others & & 10 & 9 & 8 & 7 & 17 \\
\hline $\begin{array}{l}\text { Total operating cost, } \\
\text { millions of dollars }\end{array}$ & & 1.30 & 1.46 & 1.58 & 1.93 & 2.28 \\
\hline \multicolumn{7}{|c|}{ Health Physics Research Reactor } \\
\hline \multicolumn{7}{|l|}{ Experimenter personnel } \\
\hline University & & & & & & 58 \\
\hline Industry & & & & & & 54 \\
\hline ORNL & & & & & & 15 \\
\hline Other national laboratories & & & & & & 10 \\
\hline Others & & & & & & 22 \\
\hline \multicolumn{7}{|l|}{ Use ratio, \% } \\
\hline University & & & & & & 36 \\
\hline Industry & & & & & & 34 \\
\hline ORNL & & & & & & 9 \\
\hline Other national laboratories & & & & & & 6 \\
\hline Others & & & & & & 14 \\
\hline $\begin{array}{l}\text { Total operating cost, } \\
\text { millions of dollars }\end{array}$ & & & & & & 0.545 \\
\hline
\end{tabular}

${ }^{a}$ Administered by Oak Ridge Associated Universities (ORAU).

\section{SUBCONTRACTING}

Subcontracting and procurement are two of the major types of expenditures incurred in interactions with outside institutions. Figure 9 shows that R\&D subcontracting expenditures reached a peak in FY 1980 but have declined recently like the Laboratory's funding as a whole. Despite these necessary reductions, subcontracting expenditures will remain an important part of our operations. Table 19 gives the estimated value of procurements, subcontracts, and transfers for the years of the current planning cycle. 


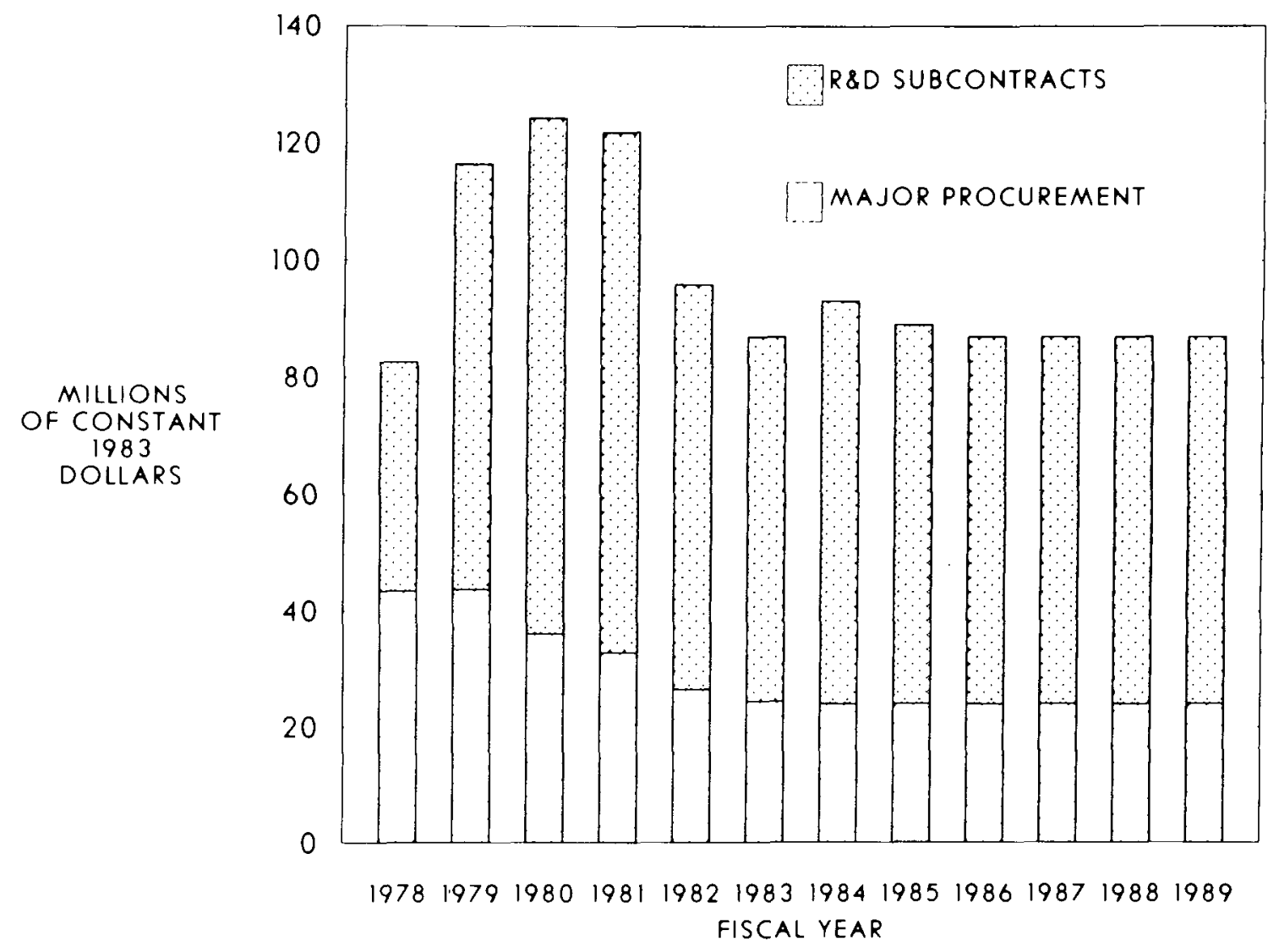

Fig. 9. Subcontracts and procurements, over time

Table 19. Procurements, subcontracts, and transfers

$(\$$ in Millions-BA)

\begin{tabular}{lcccccccc}
\hline & FY 1982 & FY 1983 & FY 1984 & FY 1985 & FY 1986 & FY 1987 & FY 1988 & FY 1989 \\
\hline Transfers & 1.9 & 1.9 & 2.0 & 1.9 & 1.9 & 1.9 & 1.9 & 1.9 \\
University subcontracts & 7.9 & 7.5 & 8.5 & 7.8 & 7.7 & 7.5 & 7.5 & 7.5 \\
All other subcontracts & 54.8 & 53.1 & 60.1 & 55.1 & 54.7 & 53.4 & 53.4 & 53.4 \\
$\quad$ Total & 64.6 & 62.5 & 70.6 & 64.8 & 64.3 & 62.8 & 62.8 & 62.8 \\
\hline
\end{tabular}

ancludes Interagency Agreements, DOE-directed contracts, and ORAU. In the past three years, interagency agreements and DOE-directed contracts made up approximately $3 \%$ of the subcontract cost, and ORAU has made up approximately $2 \%$ of the subcontract cost.

\section{UNIVERSITY PROGRAMS}

Interactions between the Laboratory and the university community continue to provide a two-way flow of technical information through formal programs and informal association. Table 20 summarizes participation in energy R\&D under the direction of the Laboratory's technical staff. The participation at ORNL during FY 1982 is summarized by type of program and by academic level of people temporarily assigned to programs. 
Table 20. Summary of ORNL-University programs for FY 1982

\begin{tabular}{|c|c|c|c|c|c|c|}
\hline Program & $\begin{array}{l}\text { Under- } \\
\text { grads }\end{array}$ & Grads & Faculty & $\begin{array}{l}\text { Post- } \\
\text { doctoral }\end{array}$ & $\begin{array}{l}\text { Total } \\
\text { people }\end{array}$ & $\begin{array}{l}\text { Total No. of } \\
\text { universities }\end{array}$ \\
\hline \multicolumn{7}{|l|}{ DOE University-Laboratory Cooperative Programs } \\
\hline \multicolumn{7}{|l|}{ ORNL funded } \\
\hline Environmental Sciences Cooperative Curriculum & 8 & & & & 8 & 4 \\
\hline $\begin{array}{l}\text { Great Lakes Colleges Association/Associated Colleges } \\
\text { of the Midwest-Oak Ridge Science Semester }\end{array}$ & 33 & & 3 & & 36 & 25 \\
\hline $\begin{array}{l}\text { Southern College University Union-Oak Ridge Science } \\
\text { Semester }\end{array}$ & 12 & & 1 & & 13 & 8 \\
\hline MIT Oak Ridge School of Chemical Engineering Practice ${ }^{\rho}$ & & 36 & 1 & & 37 & 1 \\
\hline Reactor Training Cooperative Experiments & & 38 & & & 38 & 3 \\
\hline \multicolumn{7}{|l|}{ ORAU funded } \\
\hline Faculty Research Participants & & & 10 & & 10 & $b$ \\
\hline Student Research Participants & 43 & & & & 43 & b \\
\hline Laboratory Graduate Participation & & 12 & & & 12 & $b$ \\
\hline Postgraduate Research Training & & & & 5 & 5 & $b$ \\
\hline \multicolumn{7}{|l|}{ ORNL programs (operating funds) } \\
\hline Faculty Research Participants & & & 7 & & 7 & 7 \\
\hline Summer Research Internships & & 15 & & & 15 & 15 \\
\hline Special Summer $\mathbf{A A}^{c}$ Program & 1 & & & & 1 & 1 \\
\hline Forestry Program & 0 & & & & $\mathbf{0}$ & 0 \\
\hline Pre-co-ops (AA) & 7 & & & & 7 & 7 \\
\hline Co-ops & 35 & & & & 35 & 21 \\
\hline Oak Ridge Graduate School of Biomedical Sciences & & 48 & 7 & 35 & 90 & 1 \\
\hline Wigner Fellows & & & & 5 & 5 & 5 \\
\hline ORNL guests (other sponsorship) & 41 & 106 & 179 & 2 & 328 & $b$ \\
\hline ORNL consultants & & & 98 & $\ldots$ & 98 & 62 \\
\hline Total & 180 & 255 & 306 & 47 & 788 & 160 \\
\hline
\end{tabular}

${ }^{a}$ Discontinued after FY 1982.

${ }^{b}$ Information not available.

'Affirmative action.

The sources of funding for these programs are the DOE University-Laboratory Cooperative Program; ORNL's operating funds; and guest sponsorship funds from educational institutions, agencies, or fellowships.

A total of 788 people from the academic community participated in research programs at the Laboratory in FY 1982. Many of the 180 undergraduates received academic credit from their respective universities as a result of their assignment at the Laboratory, and most of the 255 graduate students were engaged in master's or doctoral research. Of the 306 faculty included in the table, more than $\mathbf{3 0}$ are Laboratory employees on a part-time, year-round basis as adjunct research participants. Of the 47 postdoctoral fellows, five were recipients of the Laboratory's prestigious Eugene P. Wigner fellowship. At least 160 different universities sponsored the representatives from academia.

The Oak Ridge Associated Universities (ORAU) Traveling Lecture Program is also funded by DOE, and in the 1982-1983 academic year, the program listed 75 staff members from ORNL; lectures were presented at 24 universities.

For a number of years, minorities from the historically black colleges and other educational institutions have participated in the Laboratory's university relations programs and have been employed in craft, administrative and technical support, and professional positions. 
A special summer program for undergraduates in science and engineering, for which students from minority institutions have been especially encouraged to apply, was established several years ago. Nine students were supported in the summer of 1983.

ORNL has also participated for ten years in the UCC-ND Pre-co-op Scholarship Program for minority students in engineering. Employment is provided each summer for pre-co-op students who are high school graduates and who are enrolled, beginning the following fall, in one of the participating colleges and universities. After satisfactory completion of two semesters or three quarters of college, the students enter the UCC-ND Cooperative Education Program. Each year from three to five pre-co-ops are accepted into this program.

New efforts to enhance ORNL's relationship with black colleges and universities in the Southeast are continually explored. In December 1982, the Office of Fusion Energy asked ORNL to propose a program of interaction with historically black colleges and universities (HBCUs) in the area of fusion research. During the following several months, ORNL submitted a proposal for a pilot program, established criteria for selecting one or two HBCUs with whom ORNL could interact, and made four site visits. Atlanta University was identified as the HBCU with which ORNL would initiate the first such arrangement to assist a University in fusion research. This effort should result in broadening the University's role in mainstream science and remedy minority underrepresentation in those scientific fields that are within the purview of DOE's Office of Fusion Energy. This program was formalized by the signing of a Letter of Intent by the President of Atlanta University and the Director of ORNL on May 26, 1983. A Memorandum of Understanding to include other scientific and technical fields of endeavor is in process of formal endorsement. Information on planned expenditures on behalf of historically black colleges may be found in Supplementary Data. 
•

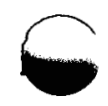




\section{SUPPLEMENTARY DATA}



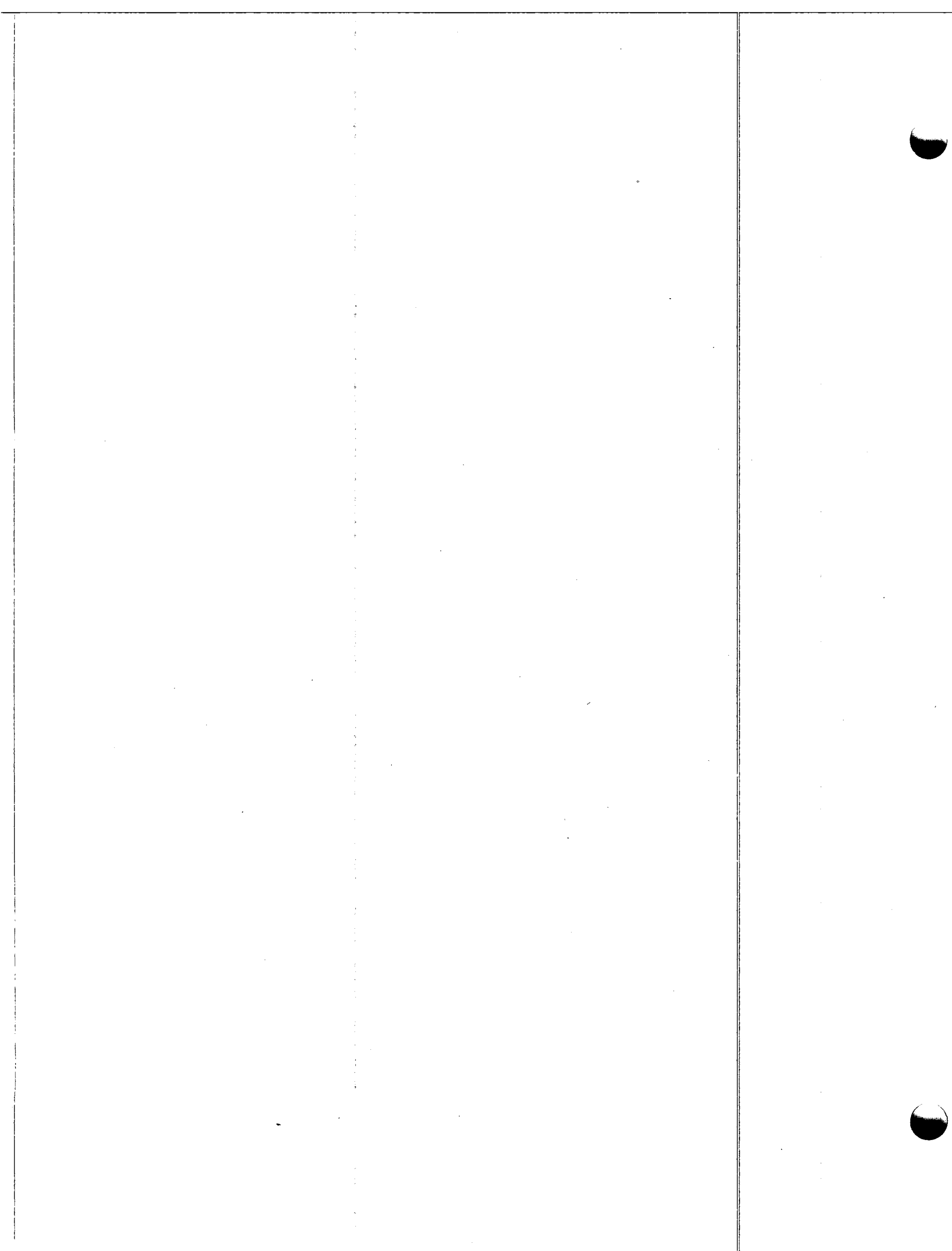
Table SD.1. Resources by subprogram

(Millions of dollars)

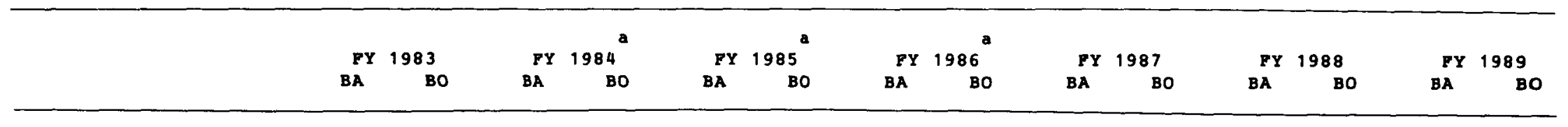

Assistant Secretary for Fossil Bnergy

AA05 Control Technology coal prep

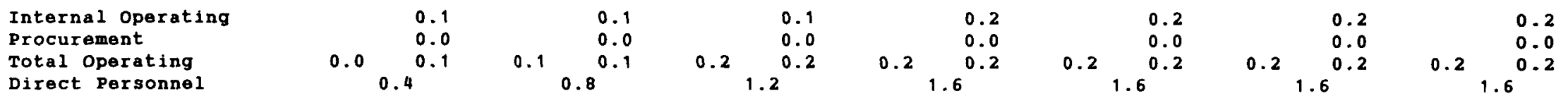

AA15 Advanced Research Technology Dev

\begin{tabular}{|c|c|c|c|c|c|c|c|c|c|c|c|c|c|c|}
\hline $\begin{array}{l}\text { Internal operating } \\
\text { Procurement }\end{array}$ & & $\begin{array}{l}3.5 \\
3.3\end{array}$ & & $\begin{array}{l}2.8 \\
3.5\end{array}$ & & $\begin{array}{l}3.6 \\
4.1\end{array}$ & & $\begin{array}{l}3.7 \\
4.1\end{array}$ & & 3.7 & & 3.7 & & $\begin{array}{l}3.7 \\
4.1\end{array}$ \\
\hline Total Operating & 5.7 & 6.8 & 6.0 & 6.3 & 7.8 & 7.6 & 7.8 & 7.8 & 7.8 & 7.8 & 7.8 & 7.8 & 7.8 & 7.8 \\
\hline $\begin{array}{l}\text { Capital Equipment } \\
\text { Total Activity }\end{array}$ & $\begin{array}{l}0.1 \\
5.9\end{array}$ & & $\begin{array}{l}0.3 \\
6.3\end{array}$ & & $\begin{array}{l}0.2 \\
8.0\end{array}$ & & $\begin{array}{l}0.3 \\
8.0\end{array}$ & & $\begin{array}{l}0.3 \\
8.0\end{array}$ & & $\begin{array}{l}0.3 \\
8.0\end{array}$ & & $\begin{array}{l}0.3 \\
8.0\end{array}$ & \\
\hline Direct Personnel & & & & & & & & & & & & & & \\
\hline
\end{tabular}

\section{AA25 Liquefaction}

Internal operating Procurement

Total Operating

Capital Bquipment

Total Activity

Direct Personnel

\begin{tabular}{llll} 
& 1.8 & & 2. \\
& 0.0 & & 0.4 \\
2.0 & 1.9 & 2.9 & 3.0 \\
0.0 & & 0.2 & \\
2.0 & & 3.1 \\
17.5 & & \multicolumn{2}{c}{19.5}
\end{tabular}

$\begin{array}{lll}2.6 & & 4.6 \\ 0.4 & & 1.1 \\ 3.0 & 6.6 & 5.6 \\ & 0.3 & \\ & 6.9 & \end{array}$

$\begin{array}{ll} & 5.2 \\ & 1.5 \\ 6.6 & 6.6 \\ 0.4 & \\ 7.0 & \\ & \end{array}$

$\begin{array}{ll} & 5.2 \\ & 1.5 \\ 6.6 & 6.6 \\ 0.4 & \\ 7.0 & \\ & \end{array}$

$\begin{array}{ll} & 5.2 \\ & 1.5 \\ 6.6 & 6.6 \\ 0.4 & \\ 7.0 & \end{array}$

$\begin{array}{ll} & 5.2 \\ & 1.5 \\ 6.6 & 6.6 \\ 0.4 & \\ 7.0 & \\ 34.0\end{array}$


Table SD.1 (continued)

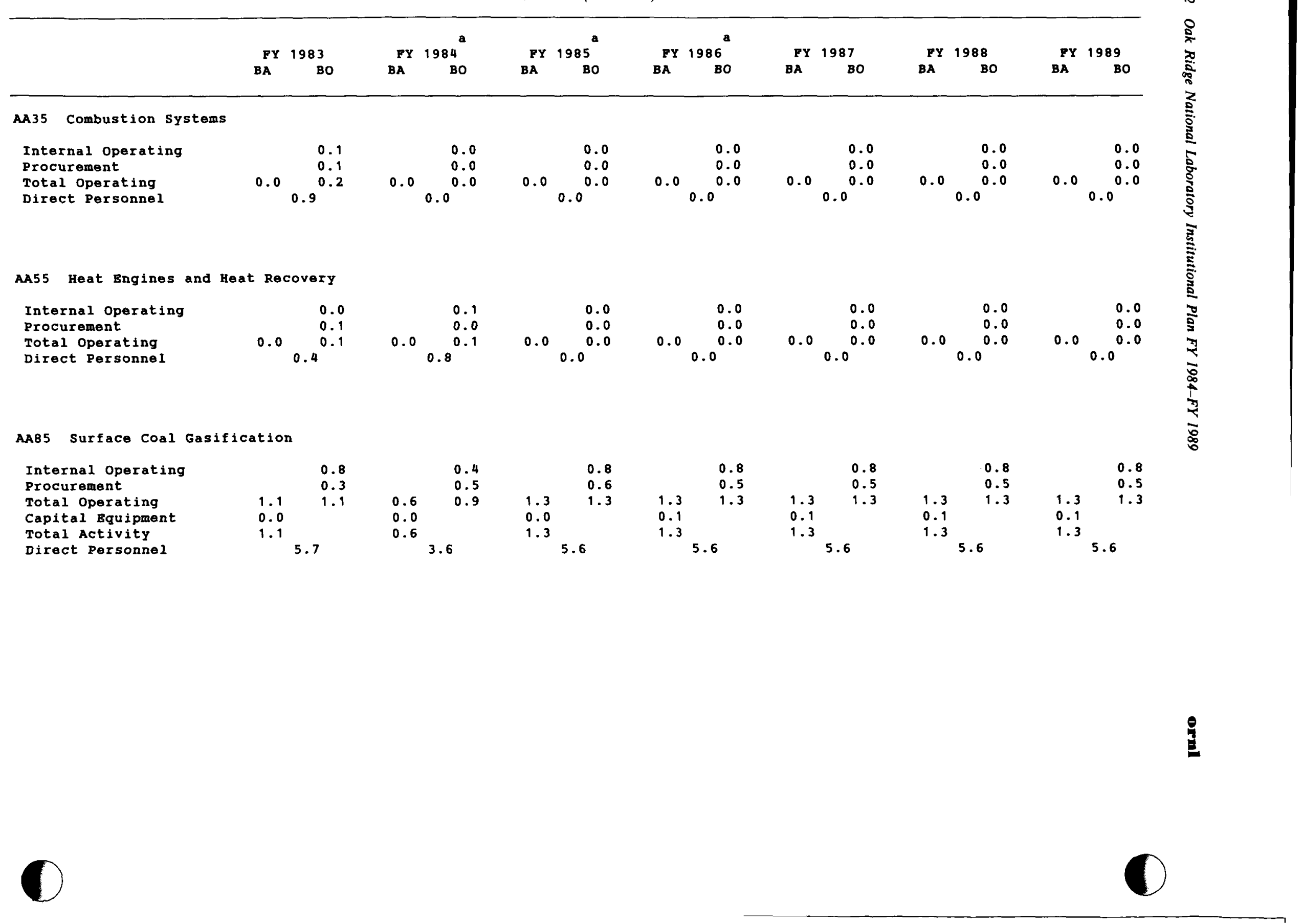


Table SD.1 (continued)

\begin{tabular}{|c|c|c|c|c|c|c|c|c|c|c|c|c|c|c|}
\hline & FY & $\begin{array}{r}1983 \\
\text { BO }\end{array}$ & $\underset{B A}{P Y}$ & $\begin{array}{l}1984^{a} \\
\text { BO }\end{array}$ & $\begin{array}{l}\text { FY } \\
\text { BA }\end{array}$ & $\begin{array}{l}1985^{a} \\
\text { BO }\end{array}$ & FY & $\begin{array}{c}1986^{a} \\
\text { 80 }\end{array}$ & $\begin{array}{c}\mathbf{F Y} \\
\mathbf{B A}\end{array}$ & $\begin{array}{r}1987 \\
\text { BO }\end{array}$ & BA & $\begin{array}{c}988 \\
\text { BO }\end{array}$ & $\begin{array}{c}\text { FY } \\
\text { BA }\end{array}$ & $\begin{array}{r}1989 \\
\text { B० }\end{array}$ \\
\hline COAL & & & & & & & & & & & & & & \\
\hline $\begin{array}{l}\text { Internal operating } \\
\text { Procurement }\end{array}$ & & $\begin{array}{l}6.4 \\
3.7\end{array}$ & & $\begin{array}{l}6.0 \\
4.4\end{array}$ & & $\begin{array}{l}9.0 \\
5.7\end{array}$ & & $\begin{array}{l}9.8 \\
6.1\end{array}$ & & $\begin{array}{l}9.8 \\
6.0\end{array}$ & & $\begin{array}{l}9.8 \\
6.0\end{array}$ & & $\begin{array}{l}9.8 \\
6.0\end{array}$ \\
\hline $\begin{array}{l}\text { Total Operating } \\
\text { Capital Bquipment } \\
\text { Total Program }\end{array}$ & $\begin{array}{l}8.9 \\
0.1 \\
9.0\end{array}$ & 10.1 & $\begin{array}{r}9.6 \\
0.5 \\
10.1\end{array}$ & 10.4 & $\begin{array}{r}15.9 \\
0.6 \\
16.4\end{array}$ & 14.7 & $\begin{array}{r}15.9 \\
0.7 \\
16.5\end{array}$ & 15.9 & $\begin{array}{r}15.9 \\
0.7 \\
16.6\end{array}$ & 15.9 & $\begin{array}{r}15.9 \\
0.7 \\
16.5\end{array}$ & 15.9 & $\begin{array}{r}15.9 \\
0.7 \\
16.5\end{array}$ & 15.9 \\
\hline Direct Personnel & & 51.0 & & 5.7 & & 0.8 & & 6.2 & & 66.2 & & 5.2 & & 66.2 \\
\hline
\end{tabular}

AB05 Bnhanced Gas Recovery : AB GAS

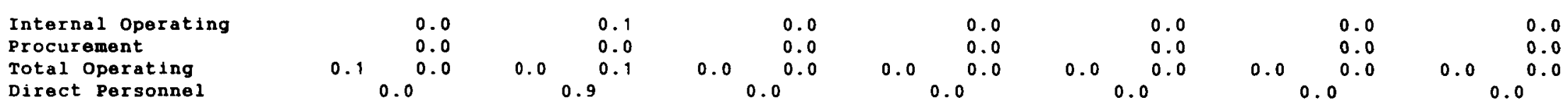

AC15 Enhanced Oil Recovery: AC PETROLEuM

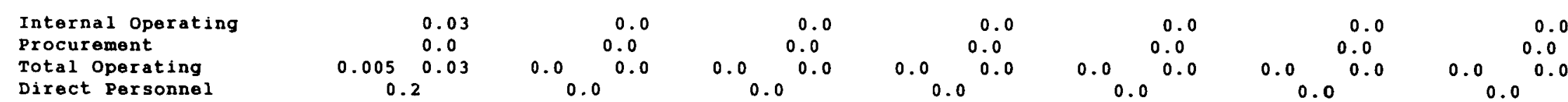

CH02 Project Devel Feasibility studies : CH ALtBRnate FUBLS PRODUCTION

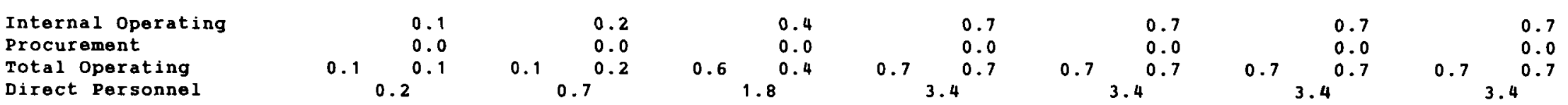


Table SD.1 (continued)

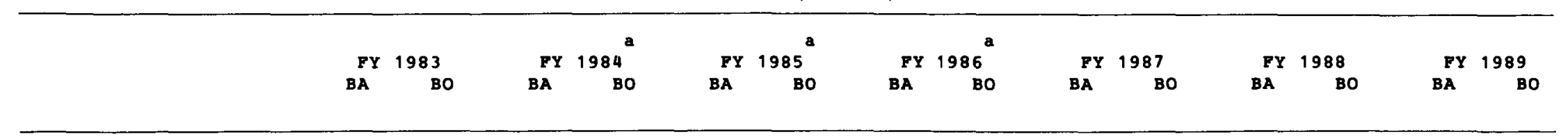

\section{Assistant Secretary for Fossil Energy}

\begin{tabular}{|c|c|c|c|c|c|c|c|c|c|c|c|c|c|c|}
\hline $\begin{array}{l}\text { Internal operating } \\
\text { Procurement }\end{array}$ & & $\begin{array}{l}6.4 \\
3.7\end{array}$ & & $\begin{array}{l}6.3 \\
4.4\end{array}$ & & $\begin{array}{l}9.4 \\
5.7\end{array}$ & & $\begin{array}{r}10.5 \\
6.1\end{array}$ & & $\begin{array}{r}10.5 \\
6.0\end{array}$ & \multicolumn{3}{|c|}{$\begin{array}{r}10.5 \\
6.0\end{array}$} & $\begin{array}{r}10.5 \\
6.0\end{array}$ \\
\hline Total Operating & 9.0 & 10.2 & 9.8 & 10.7 & 16.5 & 15.1 & 16.6 & 16.6 & 16.6 & 16.6 & 16.6 & 16.6 & 16.6 & \\
\hline Capital Equipment & 0.1 & & 0.5 & & 0.6 & & 0.7 & & 0.7 & & 0.7 & & 0.7 & \\
\hline Total Asst secretary & 9.2 & & 10.3 & & 17.1 & & 17.2 & & 17.3 & & 17.2 & & 17.3 & \\
\hline Direct Personnel & & & & & & & & & & & & & & .6 \\
\hline
\end{tabular}

Assistant Secretary for Nuclear Energy

AE20 Space and Terrestrial Applications : AB ADVANCED NUCLEAR SySteks

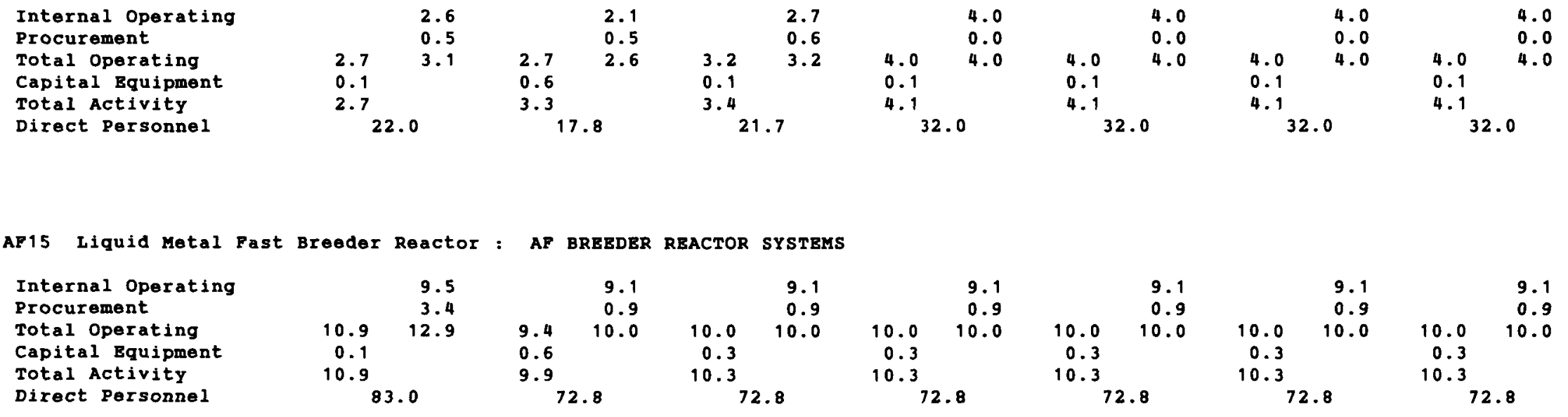


Table SD.1 (continued)

\begin{tabular}{|c|c|c|c|c|c|c|c|c|c|c|c|c|c|c|}
\hline & \multirow[b]{2}{*}{$\mathbf{F Y}$} & \multirow[b]{2}{*}{1983} & \multicolumn{2}{|r|}{ a } & \multicolumn{2}{|r|}{ a } & \multicolumn{2}{|r|}{$\mathbf{a}$} & \multirow[b]{2}{*}{$\mathbf{F Y}$} & \multirow[b]{2}{*}{387} & \multirow[b]{2}{*}{ FY } & \multirow[b]{2}{*}{988} & \multirow[b]{2}{*}{ FY } & \multirow[b]{2}{*}{1989} \\
\hline & & & $\mathbf{F Y}$ & 1984 & FY & 85 & FY & & & & & & & \\
\hline & BA & Bo & BA & BO & BA & BO & BA & BO & BA & BO & BA & Bo & BA & Bo \\
\hline High Temperature & Reactor & Techno & & & & & & & & & & & & \\
\hline Internal Operating & & 3.7 & & 4.3 & & 4.6 & & 4.9 & & 4.9 & & 4.9 & & 4.9 \\
\hline Procurement & & 0.9 & & 0.1 & & 0.2 & & 0.3 & & 0.3 & & 0.3 & & 0.3 \\
\hline Total Operating & 4.4 & 4.6 & 4.5 & 4.4 & 5.0 & 4.8 & 5.5 & 5.2 & 5.2 & 5.2 & 5.2 & 5.2 & 5.2 & 5.2 \\
\hline Capital Equipment & 1.3 & & 2.3 & & 1.8 & & 1.8 & & 2.0 & & 1.8 & & 2.0 & \\
\hline Total Activity & 5.7 & & 6.8 & & 6.8 & & 7.3 & & 7.2 & & 7.0 & & 7.2 & \\
\hline Direct Personnel & & 28.6 & & 0.0 & & & & & & & & & & 33.0 \\
\hline
\end{tabular}

AG30 Three Mile Island Activities

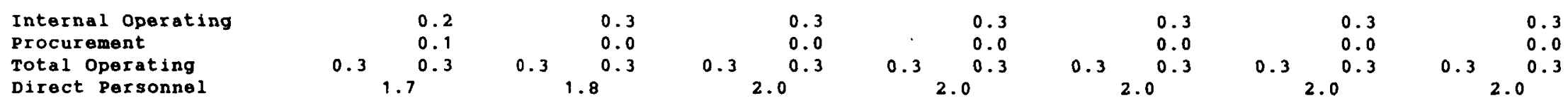

AG36 Light Water Reactor Systems

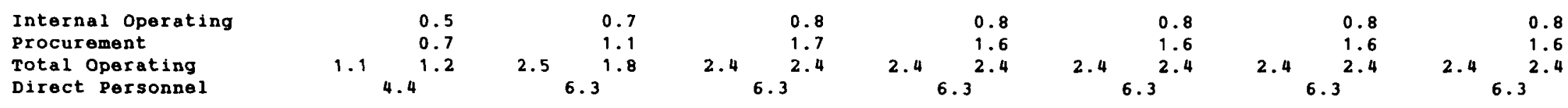

AG

CONVBRTER REACTOR SYSTEMS

Internal operating

Procurement

Total Operating

Capital Equipment

Total Program

Direct Personnel

\begin{tabular}{lrlr} 
& 4.4 & & 5.2 \\
& 1.7 & & 1.3 \\
5.8 & 6.1 & 7.4 & 6.5 \\
1.3 & & 2.3 & \\
7.1 & & 9.7 & \\
34.7 & \multicolumn{2}{c}{38.1}
\end{tabular}

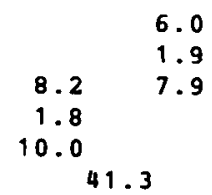

6.0
1.9
7.9

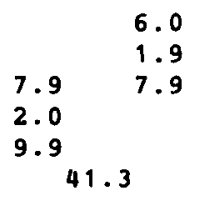


Table SD.1 (continued)

AP05 Commercial waste Management : AP COMMBRCIAL NUCLBAR wASTB MANAGEMENT

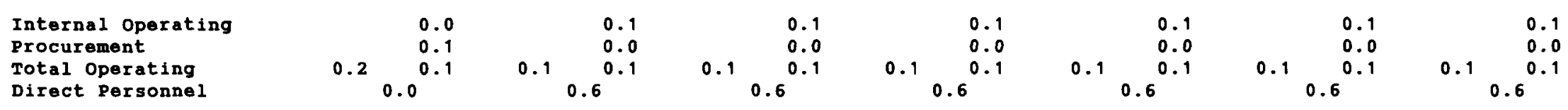

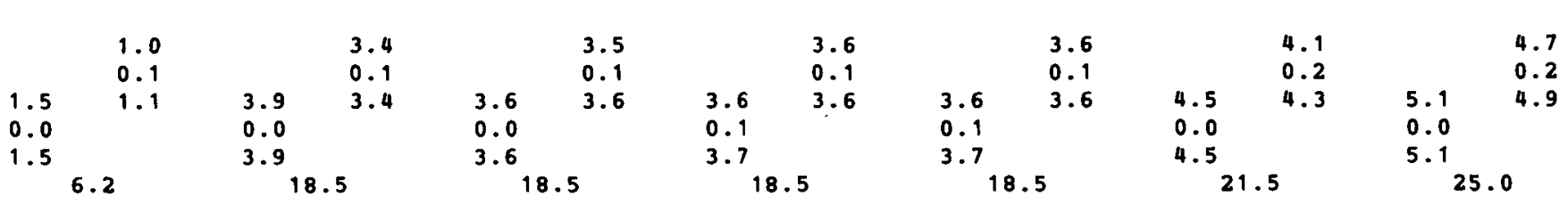

As05 Spent Fuel Technology

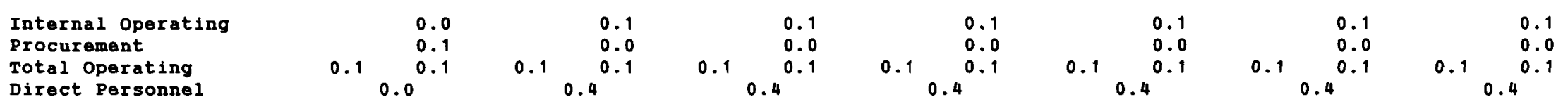


Table SD.1 (continued)

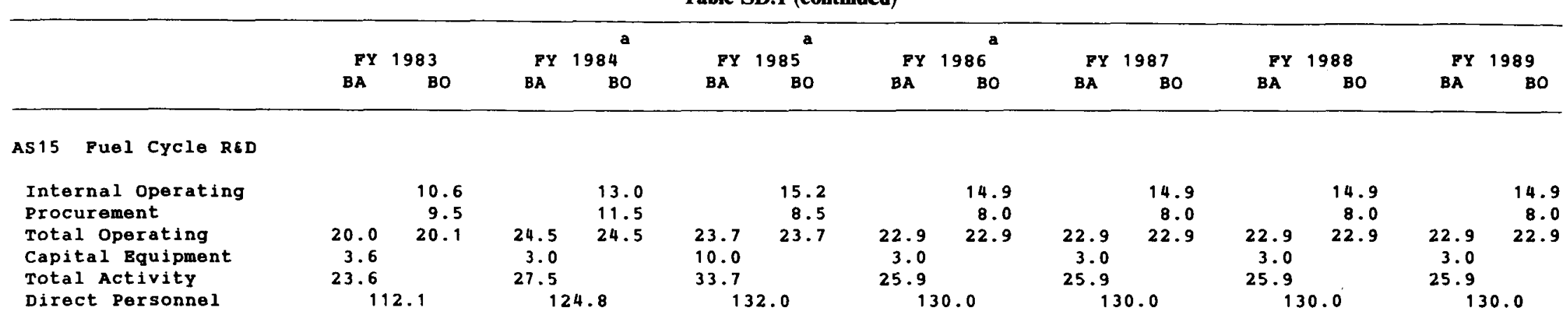

AS25 Waste Treatment RED

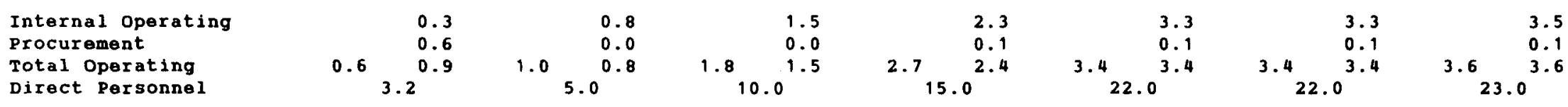

AS NUCLEAR FUEL CYCLE

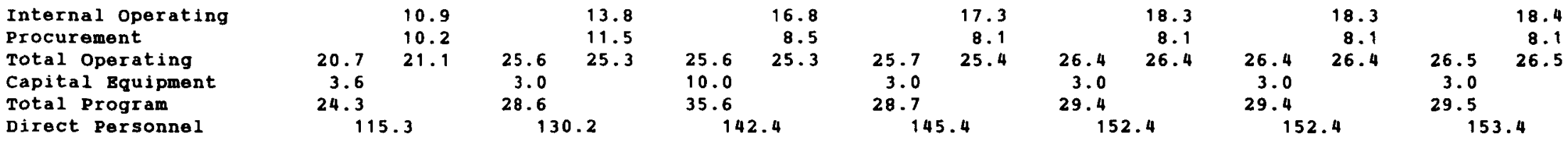


Table SD.1 (continued)

CD30 Advanced Isotope Separation Technol

\begin{tabular}{|c|c|c|c|c|c|c|c|c|c|c|c|c|c|c|}
\hline $\begin{array}{l}\text { Internal Operating } \\
\text { Procurement }\end{array}$ & 0.1 & $\begin{array}{l}0.0 \\
0.1 \\
0.1\end{array}$ & 0.0 & $\begin{array}{l}0.0 \\
0.0 \\
0.0\end{array}$ & 0.0 & $\begin{array}{l}0.0 \\
0.0 \\
0.0\end{array}$ & 0.0 & $\begin{array}{l}0.0 \\
0.0 \\
0.0\end{array}$ & 0.0 & $\begin{array}{l}0.0 \\
0.0 \\
0.0\end{array}$ & 0.0 & $\begin{array}{l}0.0 \\
0.0 \\
0.0\end{array}$ & 0.0 & $\begin{array}{l}0.0 \\
0.0 \\
0.0\end{array}$ \\
\hline Direct Personnel & \multicolumn{2}{|c|}{0.0} & \multicolumn{2}{|c|}{0.0} & \multicolumn{2}{|c|}{0.0} & \multicolumn{2}{|c|}{0.0} & \multicolumn{2}{|c|}{0.0} & \multicolumn{2}{|c|}{0.0} & \multicolumn{2}{|c|}{0.0} \\
\hline \multicolumn{15}{|c|}{ URANIUM ENRICHMENT } \\
\hline $\begin{array}{l}\text { Internal Operating } \\
\text { Procurement }\end{array}$ & & $\begin{array}{l}0.1 \\
0.4\end{array}$ & & $\begin{array}{l}0.1 \\
0.0\end{array}$ & & $\begin{array}{l}0.1 \\
0.0\end{array}$ & & $\begin{array}{l}0.0 \\
0.0\end{array}$ & & $\begin{array}{l}0.0 \\
0.0\end{array}$ & & $\begin{array}{l}0.0 \\
0.0\end{array}$ & & $\begin{array}{l}0.0 \\
0.0\end{array}$ \\
\hline Total operating & 0.4 & 0.5 & 0.1 & 0.1 & 0.1 & 0.1 & 0.0 & 0.0 & 0.0 & 0.0 & 0.0 & 0.0 & 0.0 & 0.0 \\
\hline Direct Personnel & & & & & & & & & & & & & & \\
\hline
\end{tabular}


Table SD.1 (continued)

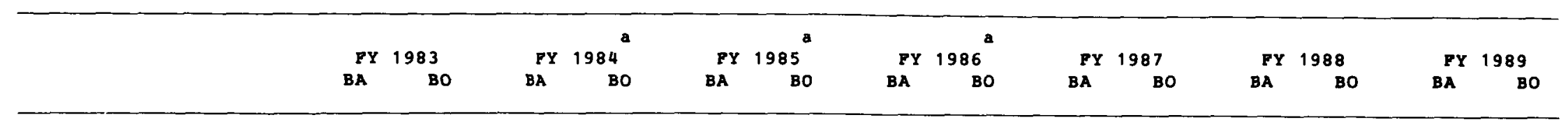

DA30 Repositories : DA NUCLEAR WASTE DISPOSAL ACTIVITIES

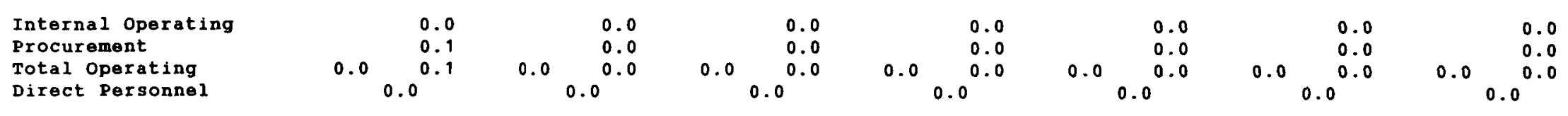

DB30 Nuclear Waste Pund Repositories

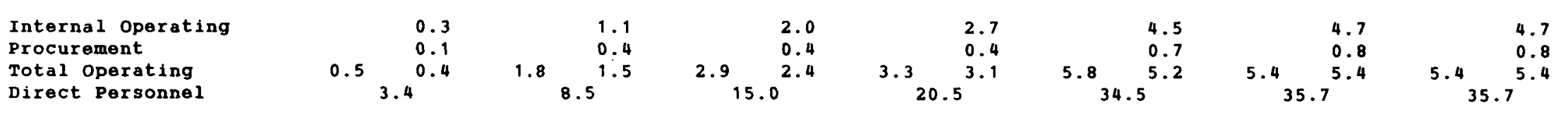

DB60 Program Management \& Tech Support

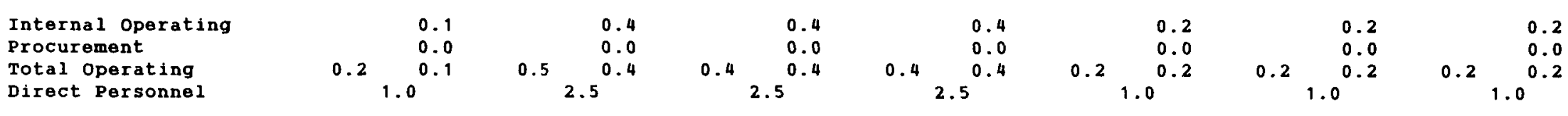

DB NUCLEAR WASTE FUND

Internal Operating

Procurement

Total operating

Direct Personnel

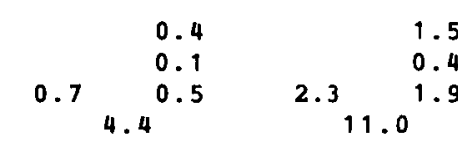

$3.3 \begin{array}{r}2.4 \\ 0.4 \\ 17.5\end{array}$

$3.7 \quad \begin{array}{r}3.1 \\ 23.0 \\ 3.5\end{array}$

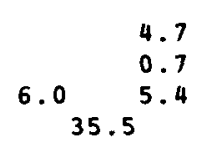

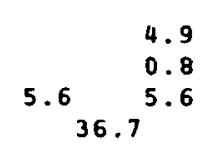

$5.6 \quad \begin{array}{r}4.9 \\ 0.8 \\ 36.7^{5.6}\end{array}$ 
Table SD.1 (continued)

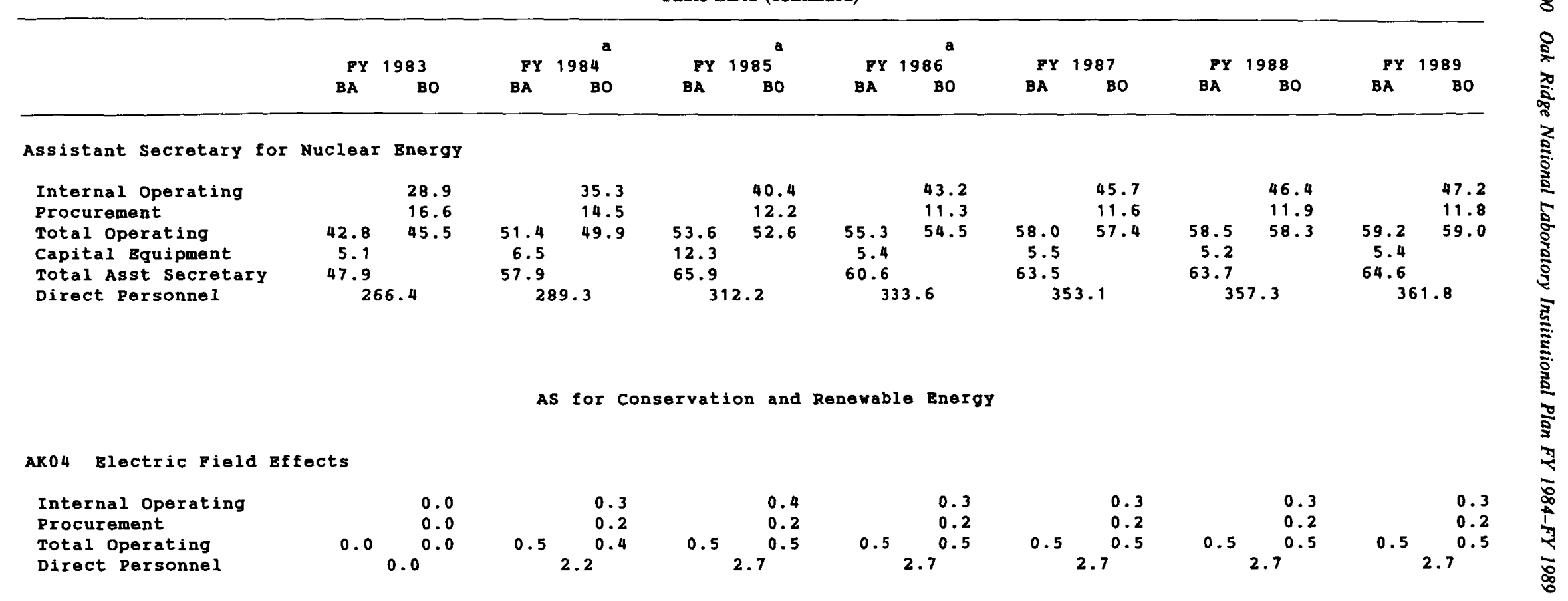

\section{AK05 Power Delivery}

\begin{tabular}{|c|c|c|c|c|c|c|c|c|c|c|c|c|c|c|}
\hline Internal operating & & 1.3 & & 1.2 & & 1.3 & & 1.4 & & 1.4 & & 1.4 & & 1.4 \\
\hline $\begin{array}{l}\text { Procurement } \\
\text { P }\end{array}$ & & 1.0 & & 1.0 & & 1.1 & & 1.1 & & 1.1 & & 1.1 & & 1.1 \\
\hline Total Operating & 1.7 & 2.3 & 2.3 & 2.2 & 2.5 & 2.4 & 2.5 & 2.5 & 2.5 & 2.5 & 2.5 & 2.5 & 2.5 & 2.5 \\
\hline $\begin{array}{l}\text { Capital Equipment } \\
\text { Total Activity }\end{array}$ & $\begin{array}{l}1.4 \\
3.1\end{array}$ & & $\begin{array}{l}0.0 \\
2.3\end{array}$ & & $\begin{array}{l}0.0 \\
2.5\end{array}$ & & $\begin{array}{l}0.0 \\
2.5\end{array}$ & & $\begin{array}{l}0.0 \\
2.5\end{array}$ & & $\begin{array}{l}0.0 \\
2.5\end{array}$ & & $\begin{array}{l}0.0 \\
2.5\end{array}$ & \\
\hline Direct Personnel & & & & & & & & & & & & & & \\
\hline
\end{tabular}


Table SD.1 (continued)

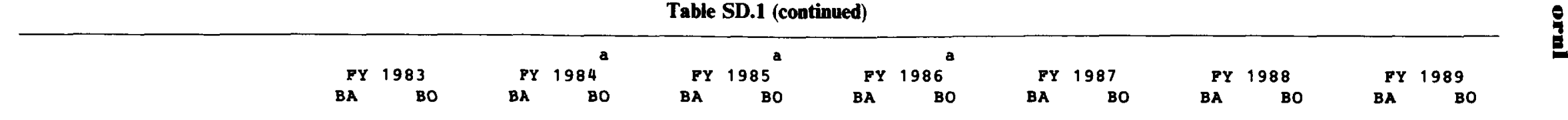

\section{AK10 Systems Architecture Integration}

\begin{tabular}{|c|c|c|c|c|c|c|c|c|c|c|c|c|c|c|}
\hline Internal Operating & & 1.0 & & 1.5 & & 1.2 & & 1.0 & & 2.0 & & 2.0 & & 2.0 \\
\hline Procurement & & 2.0 & & 3.3 & & 1.1 & & 1.0 & & 0.0 & & 0.0 & & 0.0 \\
\hline Total operating & 1.5 & 3.0 & 1.8 & 4.8 & 1.8 & 2.4 & 2.0 & 2.0 & 2.0 & 2.0 & 2.0 & 2.0 & 2.0 & 2.0 \\
\hline Direct Personnel & \multicolumn{2}{|c|}{6.0} & \multicolumn{2}{|c|}{8.0} & \multicolumn{2}{|c|}{7.0} & \multicolumn{2}{|c|}{6.0} & \multicolumn{2}{|c|}{6.0} & \multicolumn{2}{|c|}{6.0} & \multicolumn{2}{|c|}{6.0} \\
\hline
\end{tabular}

AK ELECTRIC ENERGY SYSTBMS

\begin{tabular}{|c|c|c|c|c|c|c|c|c|c|c|c|c|c|c|}
\hline Internal operating & & 2.4 & & 3.0 & & 2.9 & & 2.7 & & 3.7 & & 3.7 & & 3.7 \\
\hline Procurement & & 3.0 & & 4.5 & & 2.4 & & 2.3 & & 1.3 & & 1.3 & & 1.3 \\
\hline Total Operating & 3.2 & 5.3 & 4.5 & 7.5 & 4.8 & 5.3 & $\begin{array}{l}5.0 \\
0.0\end{array}$ & 5.0 & 5.0 & 5.0 & 5.0 & 5.0 & $\begin{array}{l}5.0 \\
0.0\end{array}$ & 5.0 \\
\hline $\begin{array}{l}\text { Capital Bquipment } \\
\text { Total Program }\end{array}$ & $\begin{array}{l}1.4 \\
4.6\end{array}$ & & $\begin{array}{l}0.0 \\
4.5\end{array}$ & & $\begin{array}{l}0.0 \\
4.8\end{array}$ & & $\begin{array}{l}0.0 \\
5.0\end{array}$ & & $\begin{array}{l}0.0 \\
5.0\end{array}$ & & $\begin{array}{l}0.0 \\
5.0\end{array}$ & & $\begin{array}{l}0.0 \\
5.0\end{array}$ & \\
\hline Direct Personnel & & & & & & & & & & & & & & \\
\hline
\end{tabular}

Al05 Battery Storage

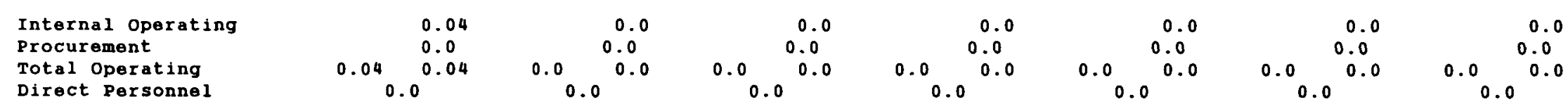

Direct Personnel

0.0

0.0

0.0

0.0

0.0

$0.0^{0.0}$

0.0

AL10 Physical and Chemical storage

Internal operating Procurement

Total Operating

Capital Equipment

Total Activity

Direct Personnel

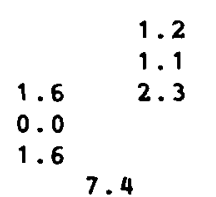

7.4
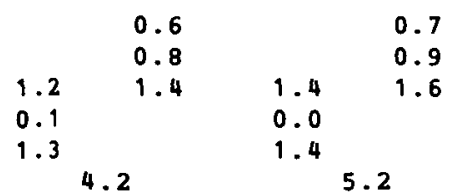

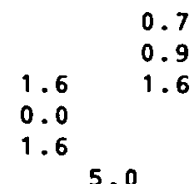

.7
0.9
.6

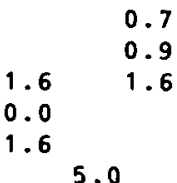

5.0 


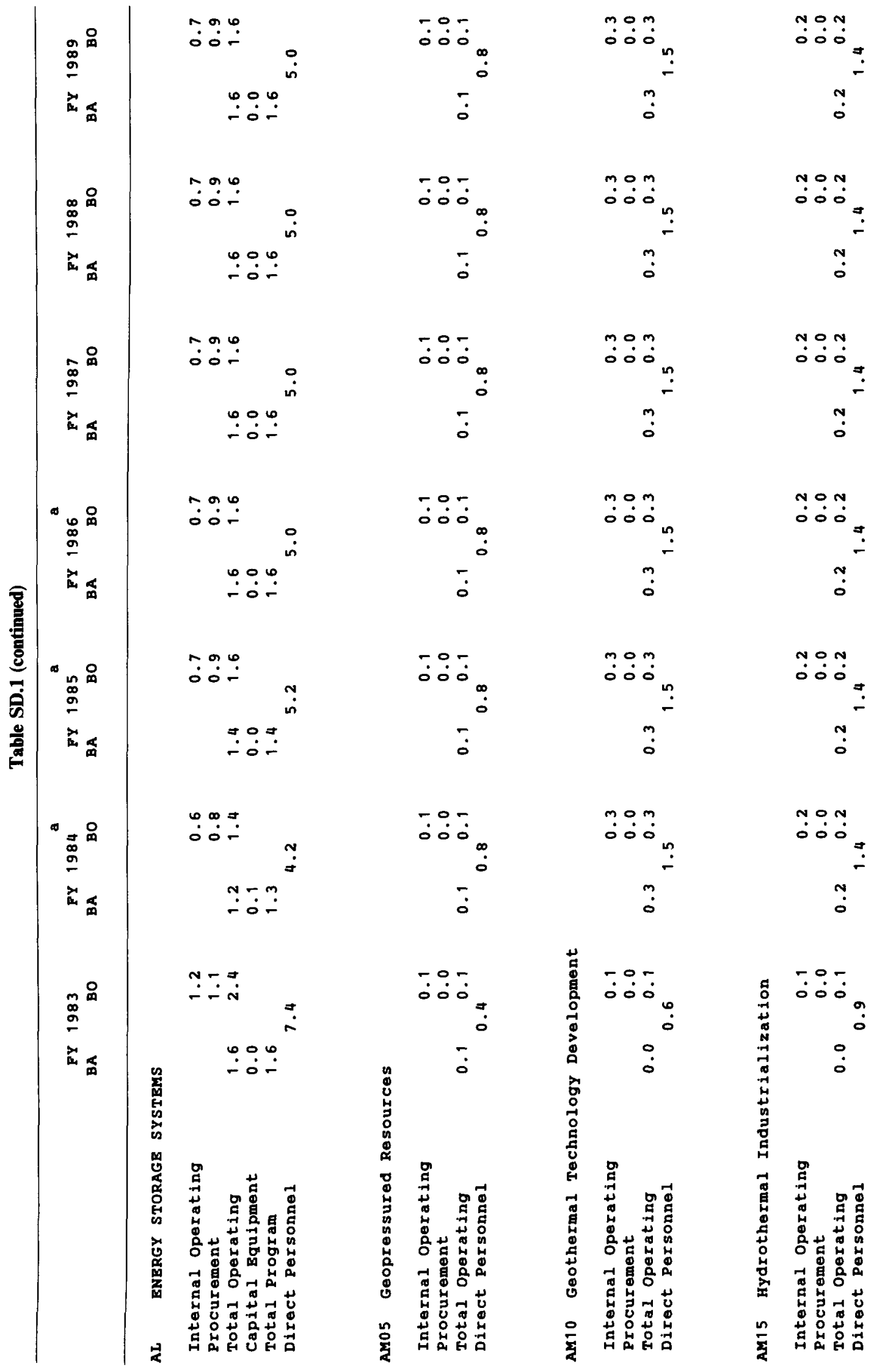


Table SD.1 (continued)

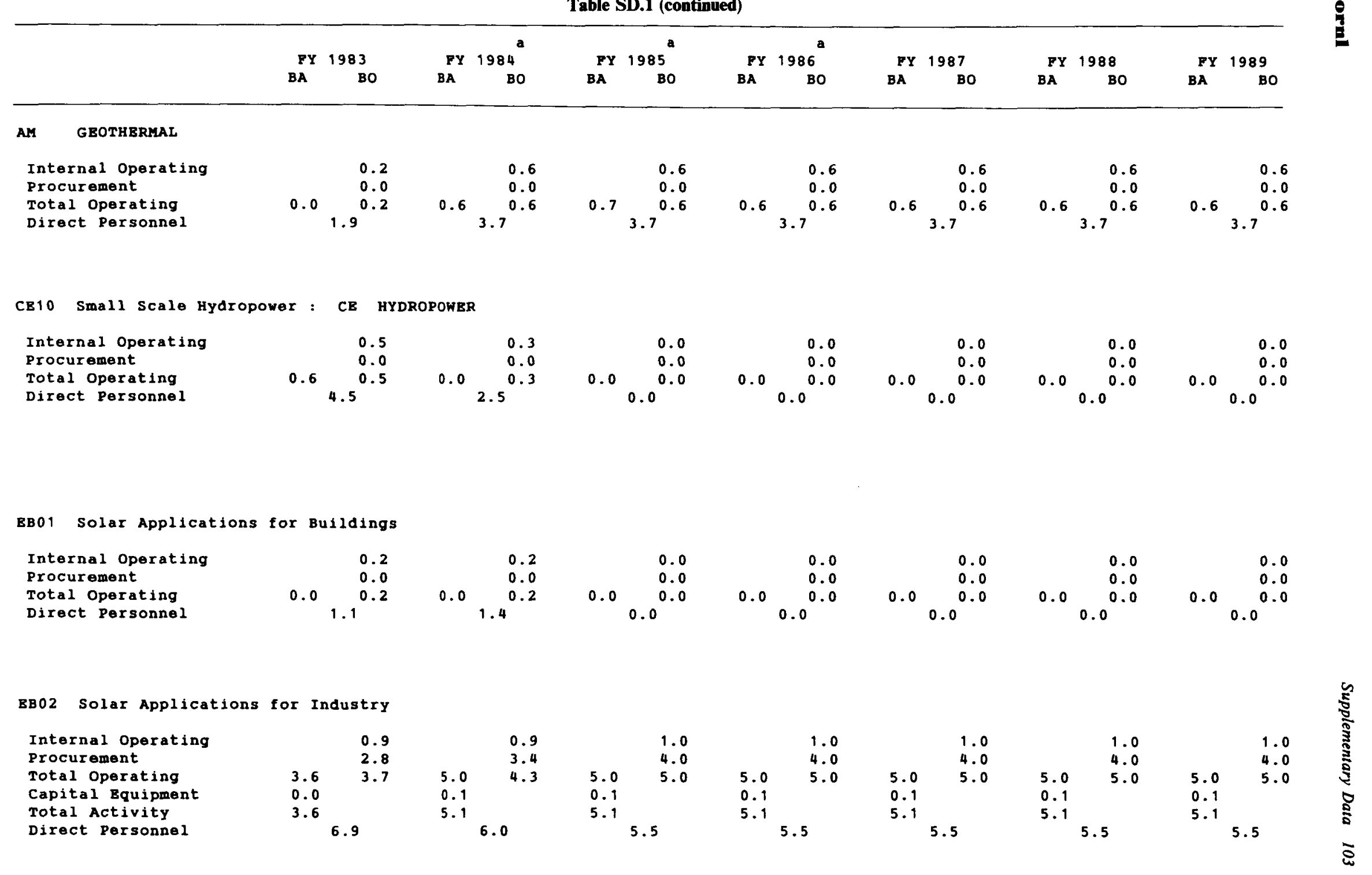




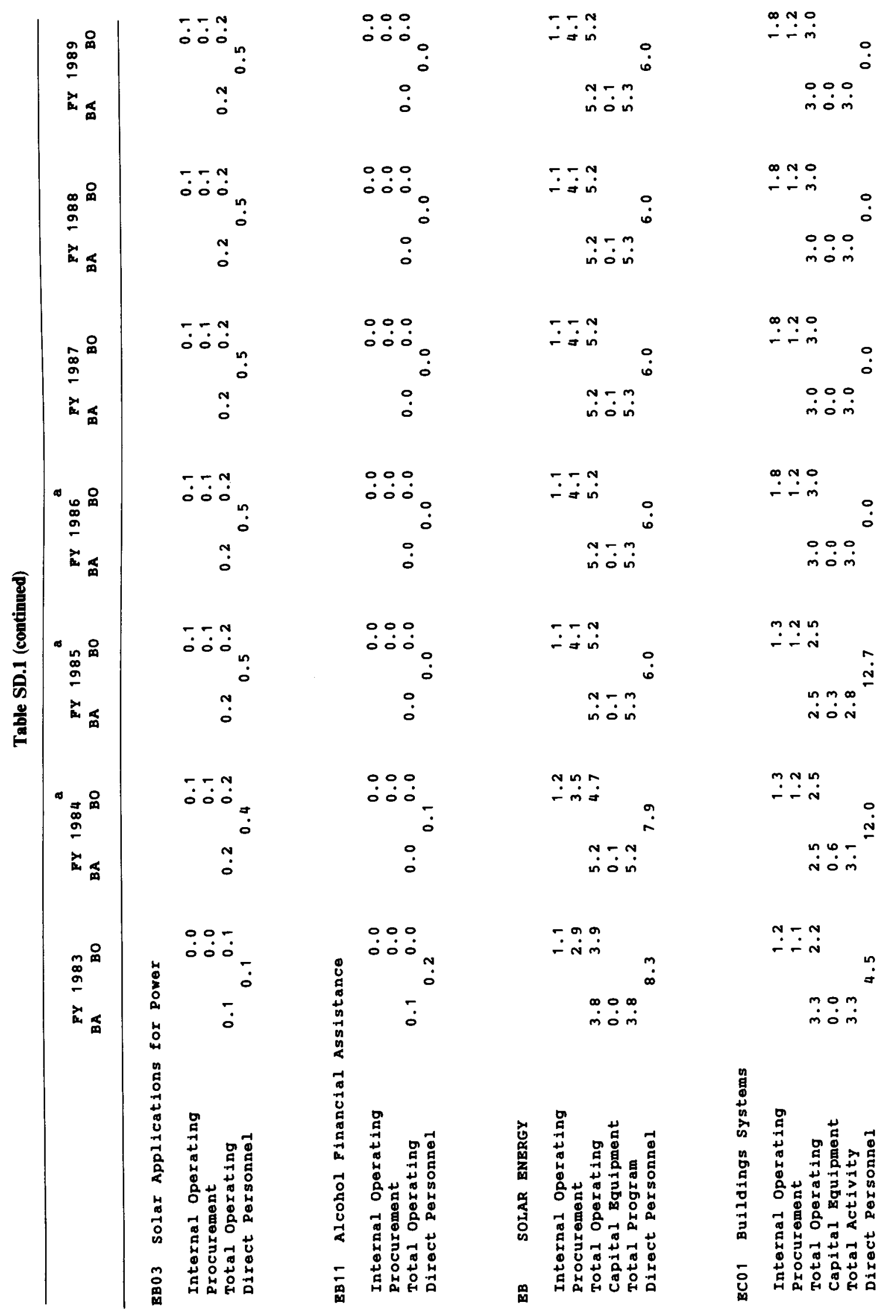


Table SD.1 (continued)

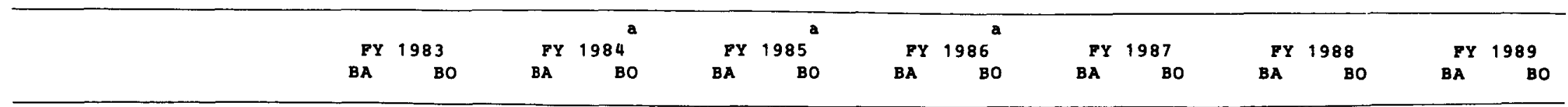

$\mathrm{ECO}_{4}$ Urban Waste

Internal operating Procurement

Total Operating

Direct Personnel

$\begin{array}{lrr}0.1 & & 0.0 \\ 0.0 & 0.0 & 0.0 \\ 1.1 & 0.1 & 0.0\end{array}$

$0.0 \quad \begin{array}{ll}0.0 \\ 0.0 \\ 0.0\end{array}$

$0.0 \quad 0.0 \begin{aligned} & 0.0 \\ & 0.0 \\ & 0.0\end{aligned}$

$0.0 \quad \begin{aligned} & 0.0 \\ & 0.0 \\ & 0.0\end{aligned}$

$0.0 \quad \begin{aligned} & 0.0 \\ & 0.0 \\ & 0.0^{0.0}\end{aligned}$

$0.0 \quad 0.0^{0.0}$

EC05 Technology and Consumer products

\begin{tabular}{|c|c|c|c|c|c|c|c|c|c|c|c|c|c|c|}
\hline Internal Operating & & 3.3 & & 2.6 & & 2.6 & & 2.7 & & 2.7 & \multicolumn{4}{|c|}{2.7} \\
\hline Procurement & & 3.6 & & 3.4 & & 3.4 & & 3.4 & & 3.4 & & 3.4 & & 3.4 \\
\hline Total Operating & 6.3 & 6.9 & 6.0 & 6.0 & 6.0 & 6.0 & 6.0 & 6.0 & 6.0 & 6.0 & 6.0 & 6.0 & 6.0 & 6.0 \\
\hline Capital Bquipment & 0.0 & & 0.3 & & 0.1 & & 0.1 & & 0.1 & & 0.1 & & 0.1 & \\
\hline Total Activity & 6.3 & & 6.3 & & 6.1 & & 6.1 & & 6.1 & & 6.1 & & 6.1 & \\
\hline Direct Personnel & & & & & & & & & & & & & & \\
\hline
\end{tabular}

BC06 Analysis and Technology Transfer

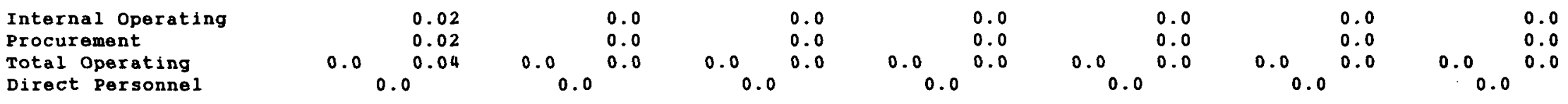

EC07 Residential Conservation Service

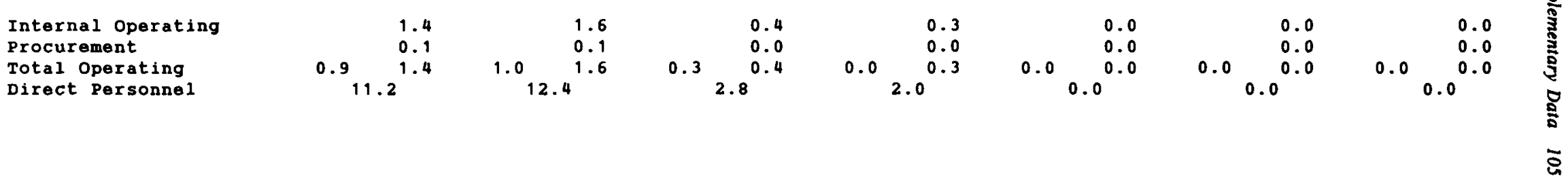


Table SD.1 (continued)

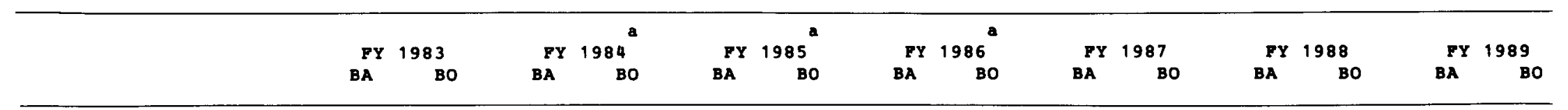

BC BUILDINGS AND COMMUNITY SYSTEMS

Internal operating Procurement

Total Operating

Capital Bquipment

Total Program

\begin{tabular}{rr} 
& 5.9 \\
& 4.8 \\
10.5 & 10.8 \\
0.0 & \\
10.5 & \\
\multicolumn{2}{c}{43.0}
\end{tabular}

\begin{tabular}{rr} 
& 5.5 \\
& 4.6 \\
9.5 & 10.1 \\
0.9 & \\
10.4 & \\
\multicolumn{2}{c}{45.4}
\end{tabular}

\begin{tabular}{lr} 
& 4.3 \\
& 4.6 \\
8.8 & 8.9 \\
0.5 & \\
9.3 & \\
\multicolumn{2}{l}{36.5}
\end{tabular}

$\begin{array}{lr} & 4.7 \\ & 4.6 \\ 9.0 & 9.3 \\ 0.1 & \\ 9.1 & \\ 23.0\end{array}$

$\begin{array}{lr} & 4.5 \\ & 4.6 \\ 9.0 & 9.0 \\ 0.1 & \\ 9.1 & \\ 21.0\end{array}$

$\begin{array}{lr} & 4.5 \\ & 4.6 \\ 9.0 & 9.0 \\ 0.1 & \\ 9.1 & \\ & \\ & 21.0\end{array}$

$\begin{array}{lr} & 4.5 \\ & 4.6 \\ 9.0 & 9.0 \\ 0.1 & \\ 9.1 & \\ 21.0\end{array}$

ED01 Waste Energy Reduction

\section{Internal Operating} Procurement

Total operating

Capital Equipment

Total Activity

Direct Personnel

\begin{tabular}{llll} 
& 1.1 & & 0.9 \\
& 0.2 & & 0.9 \\
0.6 & 1.2 & 1.8 & 1.8 \\
0.0 & & 0.1 & \\
0.6 & & 1.9 & \\
& & & \\
& 7.8 & \multicolumn{2}{c}{10.0}
\end{tabular}
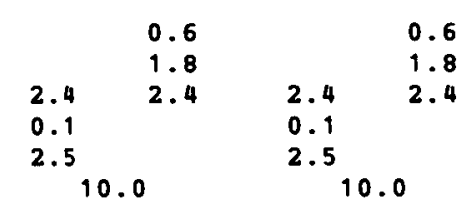

\begin{tabular}{ll} 
& 0.6 \\
& 1.8 \\
2.4 & 2.4 \\
0.1 & \\
2.5 & \\
\multicolumn{2}{c}{10.0}
\end{tabular}

$\begin{array}{ll} & 0.6 \\ & 1.8 \\ 2.4 & 2.4 \\ 0.1 & \\ 2.5 & \\ & 10.0\end{array}$

BD02 Industrial Process Bfficiency

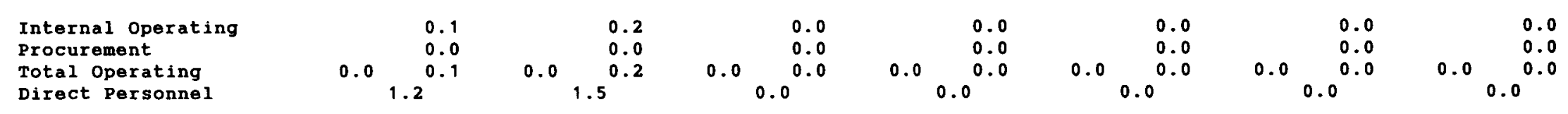

Total Operating

$1.2^{0.1}$

$1.5^{0.2}$

$0.0^{0.0}$

$0.0^{0.0}$

$0.0^{0.0}$

0.0

.0
0.0

0 
Table SD.1 (continued)

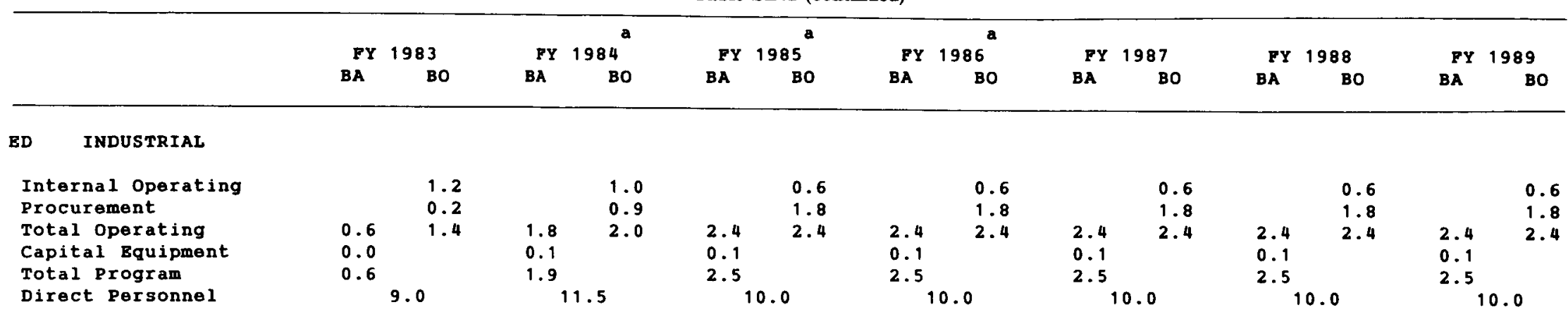

EE01 Vehicle Propulsion Research E Dev

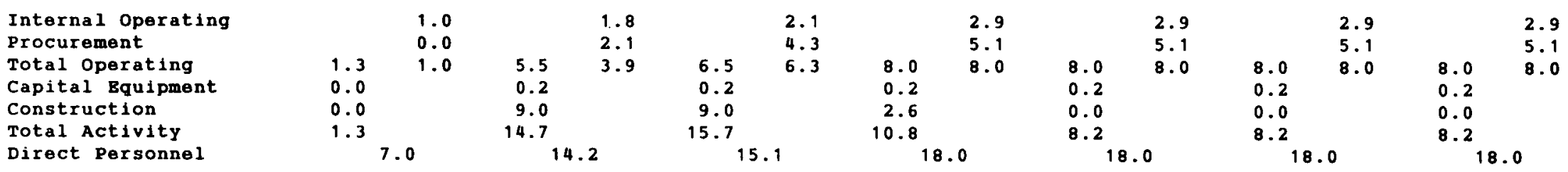

EE03 Electric/Hybrid Vehicle Program

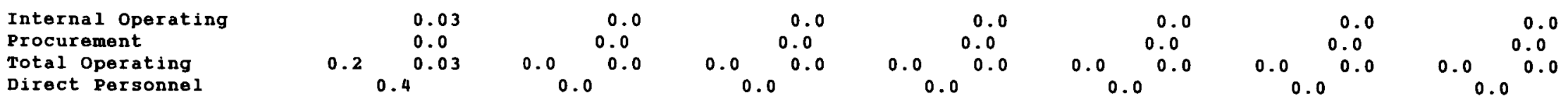

Direct Personnol

.20 .03

0.0

0.0

$0.0^{0.0}$

$0.0^{0.0}$

$0.0^{0.0}$

0.0 
Table SD.1 (continued)

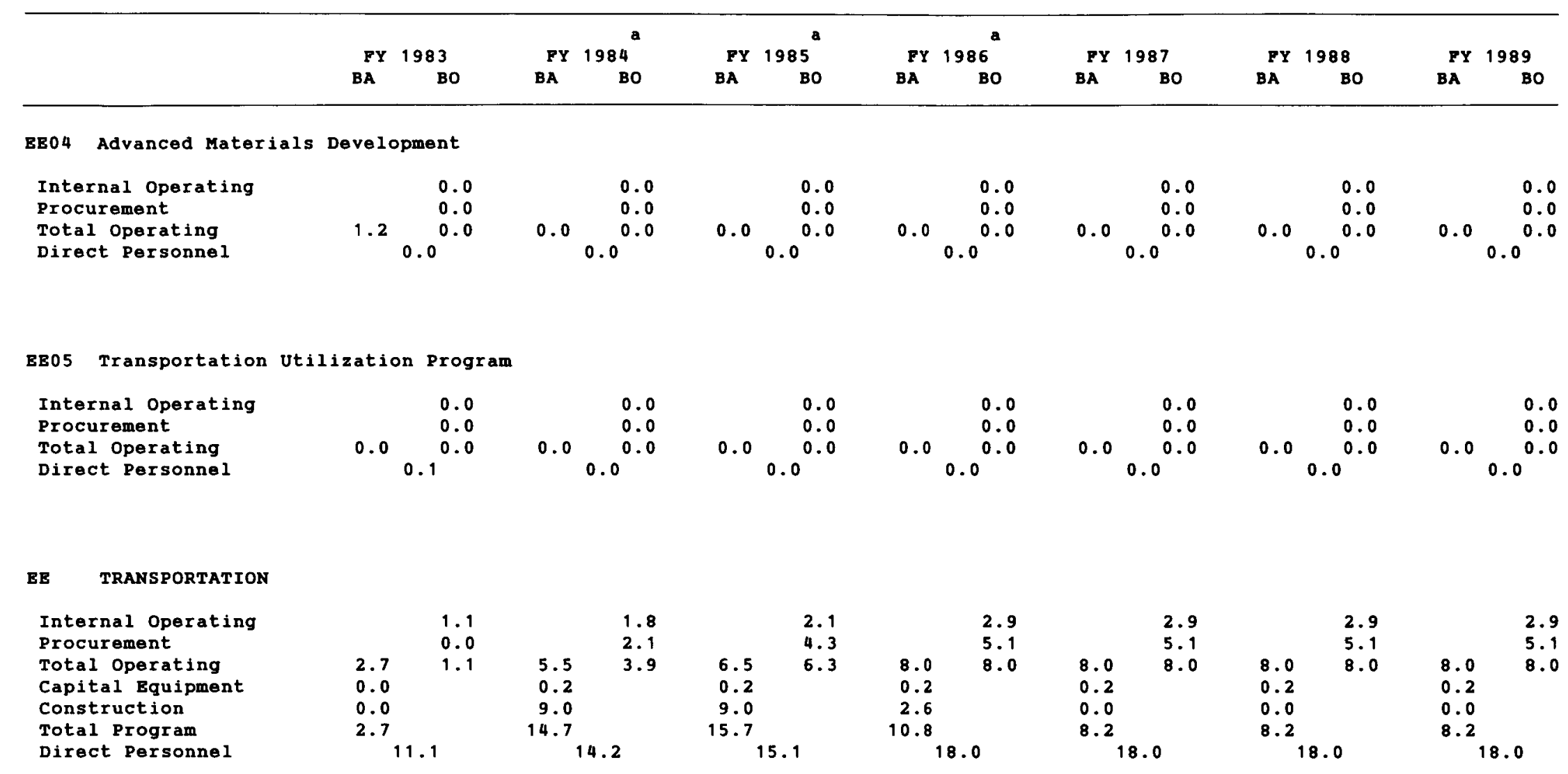


Table SD.1 (continued)

\begin{tabular}{|c|c|c|c|c|c|c|c|c|c|c|c|c|c|}
\hline & \multirow{3}{*}{$\begin{array}{cc}\text { PY } & 1983 \\
\text { BA } & \text { BO }\end{array}$} & \multirow{2}{*}{\multicolumn{2}{|c|}{ FY $1984^{a}$}} & \multirow{2}{*}{\multicolumn{2}{|c|}{ FY $1985^{a}$}} & \multirow{2}{*}{\multicolumn{2}{|c|}{ FY $1986^{a}$}} & \multirow{2}{*}{\multicolumn{2}{|c|}{ FY 1987}} & & & & \\
\hline & & & & & & & & & & \multicolumn{2}{|c|}{ Fy 1988} & \multicolumn{2}{|c|}{ FY 1989} \\
\hline BA & & BA & BO & BA & BO & BA & во & BA & во & BA & BO & BA & BO \\
\hline
\end{tabular}

EF01 Schools and Hospitals

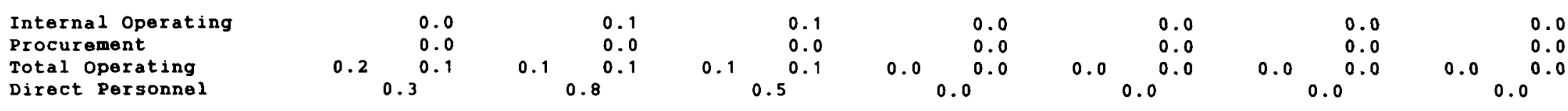

EF03 Weatherization

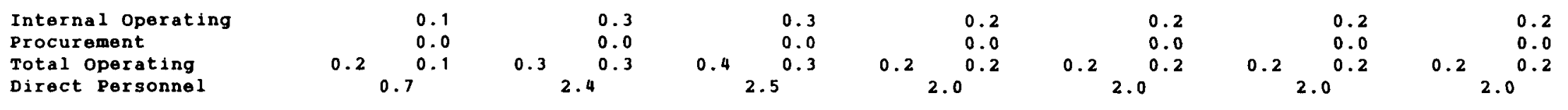

BF04 Energy Policy Conservation Grants

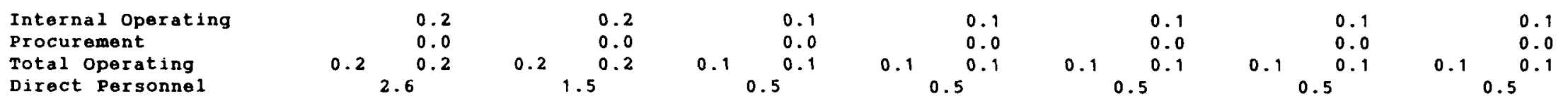


Table SD.1 (continued)

\begin{tabular}{|c|c|c|c|c|c|c|c|c|c|c|c|c|c|c|}
\hline \multirow{3}{*}{ 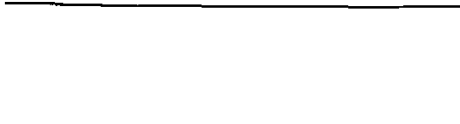 } & & & & $\mathbf{a}$ & \multirow{2}{*}{\multicolumn{2}{|c|}{$=y_{1005}^{a}$}} & \multicolumn{2}{|r|}{$\mathbf{a}$} & \multirow[b]{2}{*}{$\mathbf{F Y}$} & \multirow[b]{2}{*}{1987} & \multirow{2}{*}{\multicolumn{2}{|c|}{ FY 1988}} & \multirow{3}{*}{$\begin{array}{c}\text { FY } \\
\text { BA }\end{array}$} & \multirow{3}{*}{$\begin{array}{r}1989 \\
B 0\end{array}$} \\
\hline & FY & 1983 & FY & 1984 & FY & & Fr & 1986 & & & & & & \\
\hline & BA & BO & BA & BO & BA & во & BA & во & BA & во & BA & BO & & \\
\hline
\end{tabular}

EF05 Energy Conserv. Production Grants
Internal operating
Procurement
Total Operating

Total Operating

Direct Personnel

EF STATE/LOCAL PROGRAMS

\section{Internal operating} Procurement

Total operating

Direct Personnel

$0.2{ }_{1.3} \begin{aligned} & 0.1 \\ & 0.2\end{aligned}$

$0.1 \quad \begin{aligned} & 0.1 \\ & 0.0 \\ & 0.5\end{aligned}$

$0.1 \quad \begin{aligned} & 0.1 \\ & 0.0 \\ & 0.5\end{aligned}$

$0.1 \quad \begin{aligned} & 0.1 \\ & 0.0 \\ & 0.5\end{aligned}$

$0.1 \quad \begin{aligned} & 0.1 \\ & 0.0 \\ & 0.5\end{aligned}$

$0.10^{0.1} 0.5^{0.1}$

$10.7^{0.1}$

1.3

0.5

\section{Eg03 Energy Extension Service}

\section{Internal Operating}

Procurement

Total Operating

Direct Personnel
$0.0 \quad 2.1^{0.2}$

$0.0 \quad 0.0^{0.0}$
$0.3 \quad \begin{aligned} & 0.3 \\ & 0.0 \\ & 0.0^{0.3}\end{aligned}$

$0.3 \quad \begin{aligned} & 0.3 \\ & 0.0 \\ & 3.0^{0.3}\end{aligned}$

$0.3 \quad 0.3$
$3.0^{0.3}$

3.0
$0.0 \quad 0.0$

$0.0 \quad \begin{aligned} & 0.0 \\ & 0.0 \\ & 0.0\end{aligned}$

$0.0 \quad \begin{aligned} & 0.0 \\ & 0.0\end{aligned}$

$0.00_{0.0}^{0.0}$ 
Table SD.1 (continued)

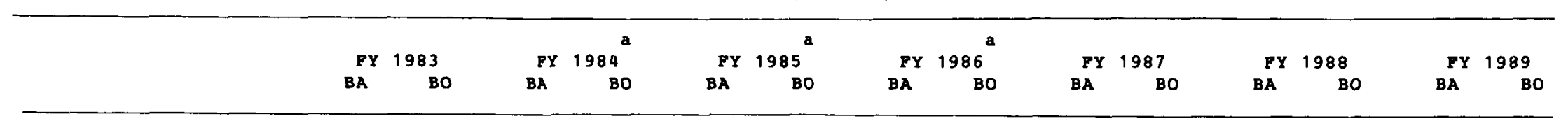

BG05 Energy Conversion Technology

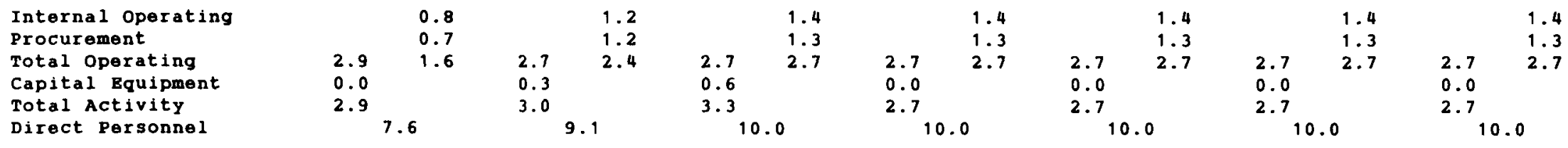

BG06 Inventors Program

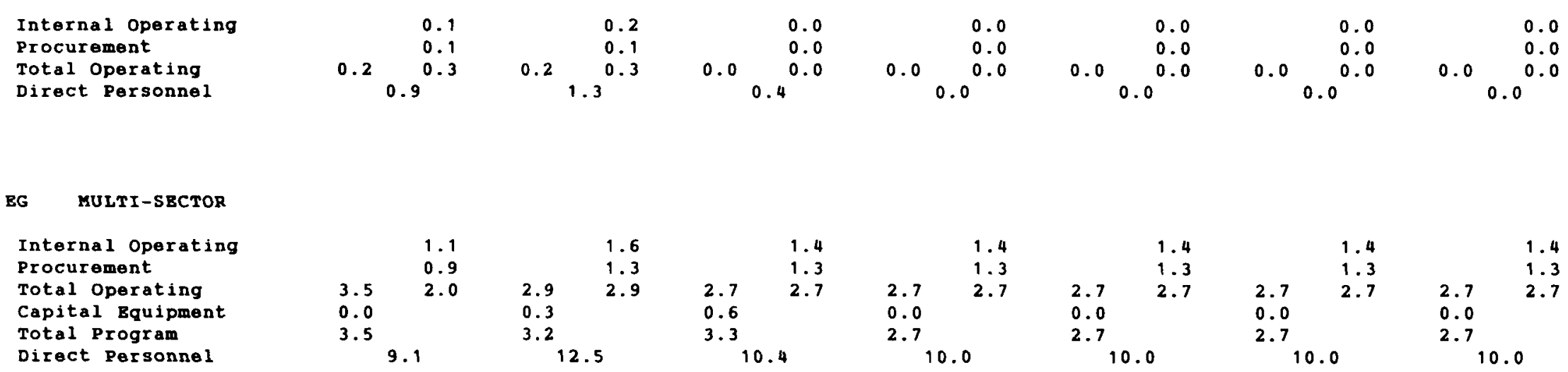


Table SD.1 (continued)

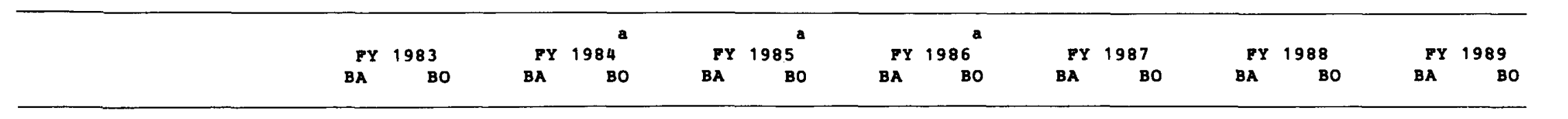

AS for Conservation and Renewable Bnergy

\begin{tabular}{|c|c|c|c|c|c|c|c|c|c|c|c|c|c|c|}
\hline $\begin{array}{l}\text { Internal operating } \\
\text { Procurement }\end{array}$ & & $\begin{array}{l}15.0 \\
13.0\end{array}$ & & $\begin{array}{l}16.2 \\
17.9\end{array}$ & & $\begin{array}{l}14.1 \\
19.4\end{array}$ & & $\begin{array}{l}15.1 \\
20.0\end{array}$ & & $\begin{array}{l}15.8 \\
19.0\end{array}$ & \multirow{2}{*}{\multicolumn{2}{|c|}{$\begin{array}{l}15.8 \\
19.0 \\
34.8\end{array}$}} & \multirow{3}{*}{$\begin{array}{r}34.8 \\
0.4\end{array}$} & \multirow{2}{*}{$\begin{array}{l}15.8 \\
19.0 \\
34.8\end{array}$} \\
\hline Total Operating & 27.1 & 28.0 & 32.0 & 34.1 & 33.0 & 33.5 & 34.8 & 35.1 & 34.8 & 34.8 & & & & \\
\hline Capital Equipment & 1.4 & & 1.6 & & 1.4 & & 0.4 & & 0.4 & & 0.4 & & & \\
\hline Construction & 0.0 & & 9.0 & & 9.0 & & 2.6 & & 0.0 & & 0.0 & & 0.0 & \\
\hline Total Asst Secretary & 28.5 & & 42.6 & & 43.4 & & 37.9 & & 35.3 & & 35.3 & & 35.3 & \\
\hline Direct Personnel & 11 & & 12 & & & & & 9 & & & & & & 9 \\
\hline
\end{tabular}

Office of Policy, Planning Analysis

PEO1 Policy, Planning and Analysis : PE POLICY ANALYSIS E SYSTEMS STUdIES

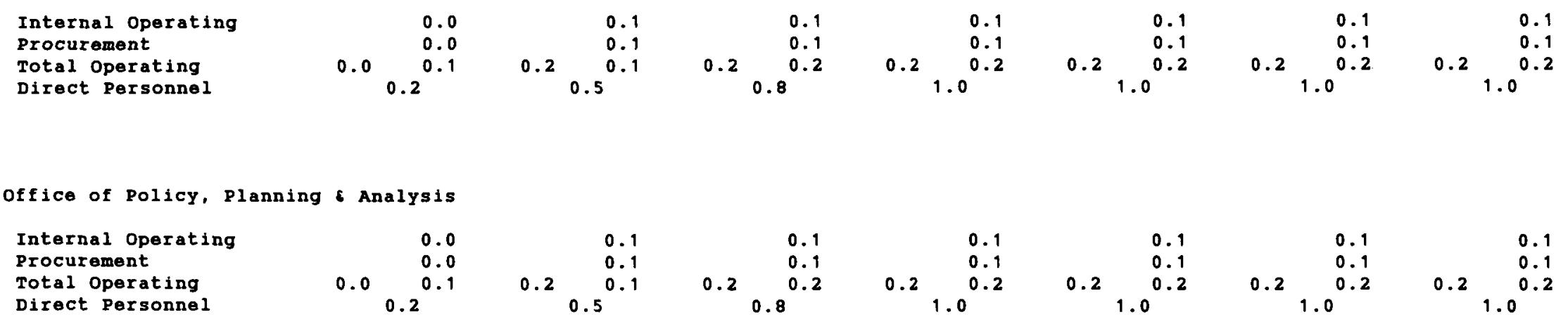


Table SD.1 (continued)

\begin{tabular}{|c|c|c|c|c|c|c|c|c|c|c|c|c|c|}
\hline & & & $\mathbf{a}$ & & $\mathbf{a}$ & & $\mathbf{a}$ & & & & & & \\
\hline & FY 1983 & FY & 1984 & $F Y$ & 1985 & $F \mathbf{Y}$ & 1986 & PY & 1987 & & 1988 & FY & 1989 \\
\hline BA & A $\quad$ BO & BA & BO & BA & BO & BA & Bо & BA & Bо & BA & BO & BA & Bo \\
\hline
\end{tabular}

Office of Energy Research

AT05 Applied Plasma Physics

\begin{tabular}{|c|c|c|c|c|c|c|c|c|c|c|c|c|c|c|}
\hline \multirow{4}{*}{$\begin{array}{l}\text { Internal operating } \\
\text { Procurement } \\
\text { Total operating } \\
\text { Capital Equipment } \\
\text { Total Activity }\end{array}$} & & \multirow{2}{*}{\multicolumn{2}{|c|}{$\begin{array}{l}4.6 \\
0.4\end{array}$}} & \multirow{3}{*}{$\begin{array}{l}4.7 \\
0.4 \\
5.2\end{array}$} & & \multirow{2}{*}{$\begin{array}{l}5.4 \\
0.5\end{array}$} & & \multirow{2}{*}{\multicolumn{2}{|c|}{$\begin{array}{l}5.6 \\
0.3\end{array}$}} & \multirow{2}{*}{$\begin{array}{l}5.6 \\
0.3\end{array}$} & \multirow{2}{*}{\multicolumn{3}{|c|}{$\begin{array}{l}5.6 \\
0.3\end{array}$}} & \multirow{2}{*}{$\begin{array}{l}5.6 \\
0.3\end{array}$} \\
\hline & & & & & & & & & & & & 0.3 & & \\
\hline & 5.3 & 5.0 & 5.3 & & 7.0 & 5.9 & 5.9 & 5.9 & 5.9 & 5.9 & 5.9 & 5.9 & 5.9 & 5.9 \\
\hline & $\begin{array}{l}0.7 \\
5.4\end{array}$ & & $\begin{array}{l}0.2 \\
5.5\end{array}$ & & $\begin{array}{l}1.2 \\
8.2\end{array}$ & & $\begin{array}{l}0.2 \\
6.1\end{array}$ & & $\begin{array}{l}0.2 \\
6.1\end{array}$ & & $\begin{array}{l}0.2 \\
6.1\end{array}$ & & $\begin{array}{l}0.2 \\
6.1\end{array}$ & \\
\hline Direct Personnel & & & & & & & & & & & & & & \\
\hline
\end{tabular}

AT10 Confinement systems

\begin{tabular}{|c|c|c|c|c|c|c|c|c|c|c|c|c|c|c|}
\hline \multirow{4}{*}{$\begin{array}{l}\text { Internal operating } \\
\text { Procurement } \\
\text { Total operating } \\
\text { Capital Equipment }\end{array}$} & \multirow{2}{*}{\multicolumn{2}{|c|}{$\begin{array}{r}16.7 \\
3.9\end{array}$}} & \multirow{2}{*}{\multicolumn{2}{|c|}{$\begin{array}{r}21.5 \\
7.7\end{array}$}} & \multicolumn{2}{|r|}{21.8} & \multicolumn{2}{|r|}{22.4} & \multicolumn{2}{|r|}{22.4} & \multicolumn{3}{|c|}{22.4} & \multirow{2}{*}{$\begin{array}{r}22.4 \\
7.8\end{array}$} \\
\hline & & & & & & 8.5 & & 7.8 & & 7.8 & \multirow{2}{*}{\multicolumn{2}{|c|}{$\begin{array}{r}7.8 \\
30.2\end{array}$}} & & \\
\hline & 30.0 & 20.6 & 24.5 & 29.2 & 32.4 & 30.2 & 30.2 & 30.2 & 30.2 & 30.2 & & & 30.2 & 30.2 \\
\hline & 2.9 & & 1.2 & & 3.6 & & 3.5 & & 3.5 & & 3.5 & & 3.5 & \\
\hline Total Activity & 32.9 & & 25.7 & & 36.0 & & 33.7 & & 33.7 & & 33.7 & & 33.7 & \\
\hline Direct Personnel & & .2 & & .3 & & .3 & & .3 & & .3 & & .3 & & .3 \\
\hline
\end{tabular}

AT15 Development and Technology

\begin{tabular}{|c|c|c|c|c|c|c|c|c|c|c|c|c|c|c|}
\hline $\begin{array}{l}\text { Internal operating } \\
\text { Procurement }\end{array}$ & & $\begin{array}{l}19.2 \\
13.8\end{array}$ & & $\begin{array}{l}12.4 \\
16.7\end{array}$ & & $\begin{array}{l}18.8 \\
13.3\end{array}$ & & $\begin{array}{l}18.8 \\
13.3\end{array}$ & & $\begin{array}{l}18.8 \\
13.3\end{array}$ & & $\begin{array}{l}18.8 \\
13.3\end{array}$ & & $\begin{array}{l}18.8 \\
13.3\end{array}$ \\
\hline Total Operating & 32.6 & 32.9 & 29.2 & 29.1 & 40.7 & 32.1 & 32.1 & 32.1 & 32.1 & 32.1 & 32.1 & 32.1 & 32.1 & 32.1 \\
\hline $\begin{array}{l}\text { Capital Bquipment } \\
\text { Total Activity }\end{array}$ & $\begin{array}{r}5.2 \\
37.7\end{array}$ & & $\begin{array}{r}3.8 \\
33.0\end{array}$ & & $\begin{array}{r}3.2 \\
43.9\end{array}$ & & $\begin{array}{r}3.0 \\
35.1\end{array}$ & & $\begin{array}{r}3.0 \\
35.1\end{array}$ & & $\begin{array}{r}3.0 \\
35.1\end{array}$ & & $\begin{array}{r}3.0 \\
35.1\end{array}$ & \\
\hline Direct Personnel & & & & & & & & & & & & & & .7 \\
\hline
\end{tabular}


Table SD.1 (continued)

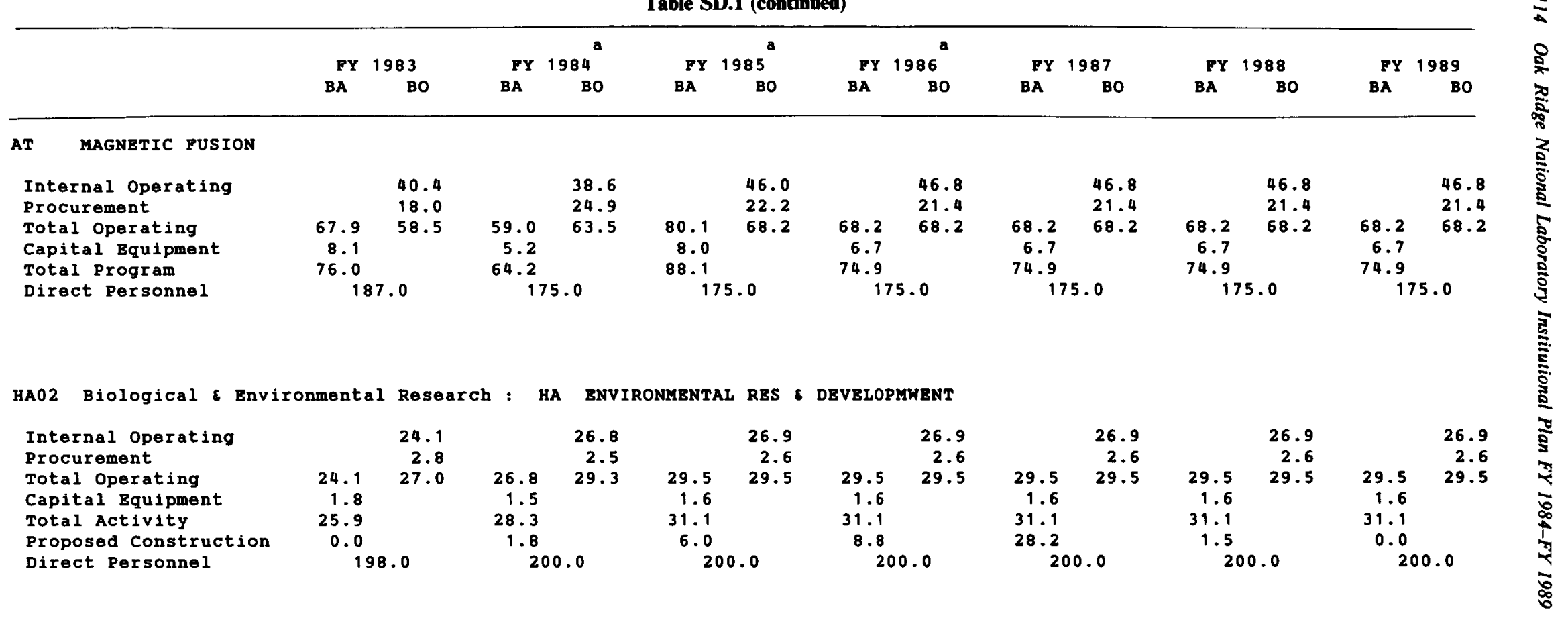

KA01 Physics Research : KA HIGH ENERGY PHYSICS

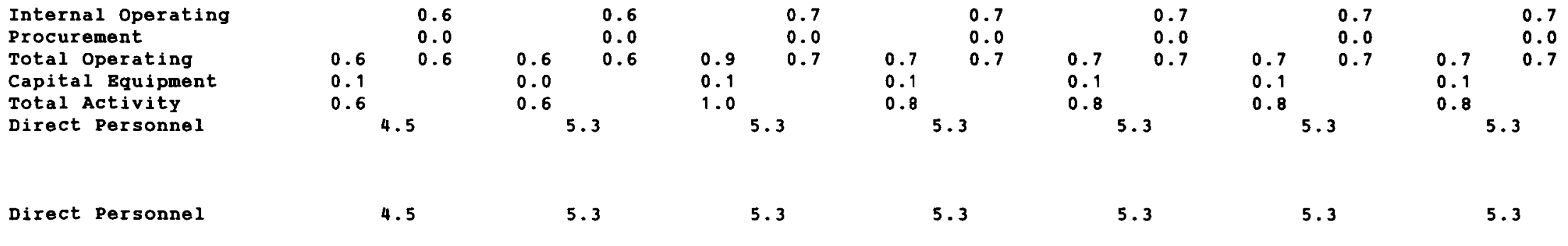


Table SD.1 (continued)

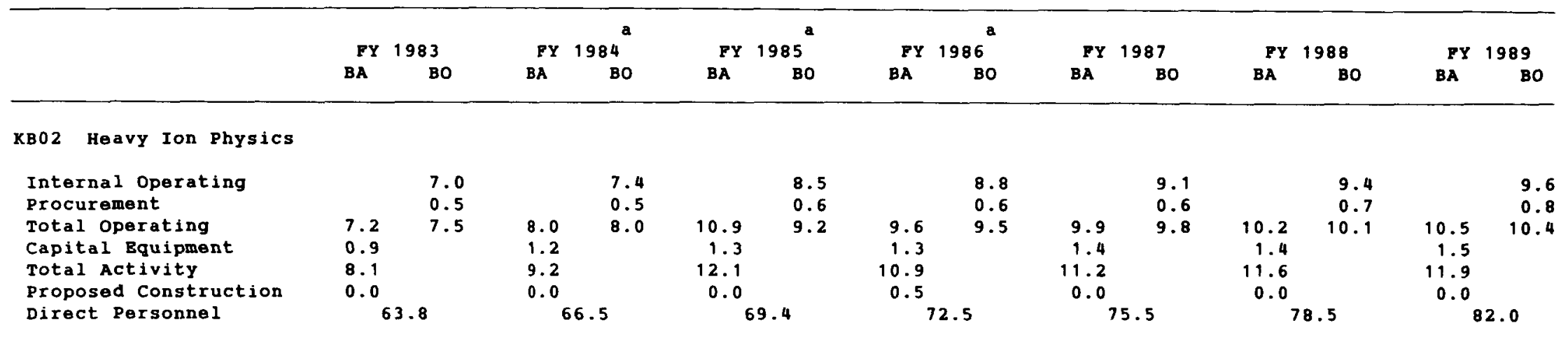

KBO3 Nuclear Theory

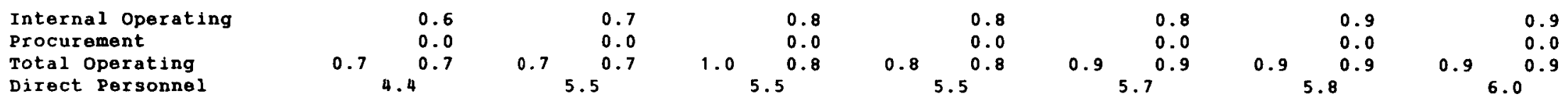

KBO4 LOW Bnergy Physics

Internal Operating

Procurement

Total Operating

Capital Equipment

Total Activity

\begin{tabular}{|c|c|c|c|c|c|}
\hline & 0.7 & & 0.8 & & 0.9 \\
\hline & 0.1 & & 0.1 & & 0.1 \\
\hline 0.8 & 0.8 & 0.9 & 0.9 & 1.3 & 1.0 \\
\hline 0.1 & & 0.1 & & 0.1 & \\
\hline 0.9 & & 1.0 & & 1.3 & \\
\hline & & & & & \\
\hline
\end{tabular}

$\begin{array}{ll} & 1.0 \\ & 0.0 \\ 1.0 & 1.0 \\ 0.1 & \\ 1.1 & \\ & 7.6\end{array}$

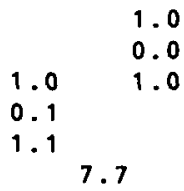

$\begin{array}{ll} & 1.0 \\ & 0.0 \\ 1.0 & 1.0 \\ 0.1 & \\ 1.1 & \\ & 7.8\end{array}$

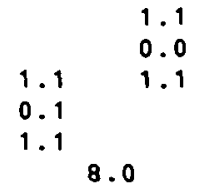


Table SD.1 (continued)

xc01 Nuclear Sciences

\section{Internal operating}

Procurement

Total Operating

Capital Bquipment

Construction

Total Activity

Proposed Construction

Direct Personnel

$\begin{array}{cr} & 16.2 \\ & 0.3 \\ 15.7 & 16.5 \\ 0.6 & \\ 0.0 & \\ 16.3 & \\ 0.0 & \\ 151.2\end{array}$

$\begin{array}{rr} & 16.0 \\ & 0.8 \\ 16.7 & 16.7 \\ 1.0 & \\ 0.3 & \\ 17.9 & \\ 0.0 & \\ 150.0\end{array}$

$\begin{array}{rr} & 17.4 \\ & 0.8 \\ 22.2 & 18.1 \\ 1.2 & \\ 0.0 & \\ 23.5 & \\ 0.6 & \\ 146.9\end{array}$

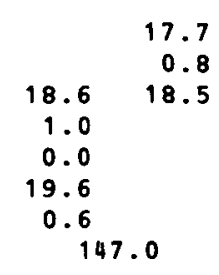

$\begin{array}{rr} & 17.7 \\ & 0.8 \\ 18.5 & 18.5 \\ 1.0 & \\ 0.0 & \\ 19.5 & \\ 0.0 & \\ 147.0\end{array}$

$\begin{array}{rr} & 17.7 \\ & 0.8 \\ 18.5 & 18.5 \\ 1.0 & \\ 0.0 & \\ 19.5 & \\ 0.0 & \\ 147.0\end{array}$

$\begin{array}{rr} & 17.7 \\ & 0.8 \\ 18.5 & 18.5 \\ 1.0 & \\ 0.0 & \\ 19.5 & \\ 0.0 & \\ & \\ & \\ & \end{array}$

KCO2 Materials Sciences

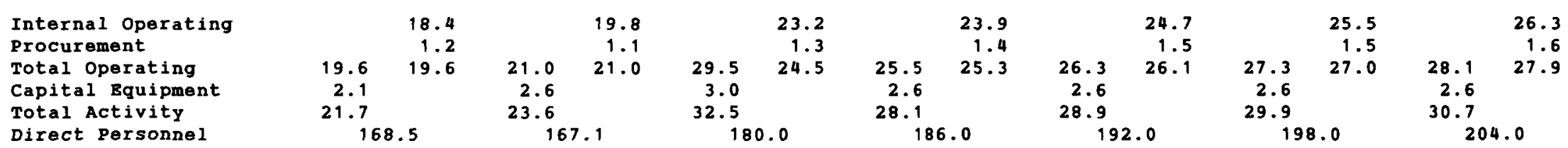


Table SD.1 (continued)

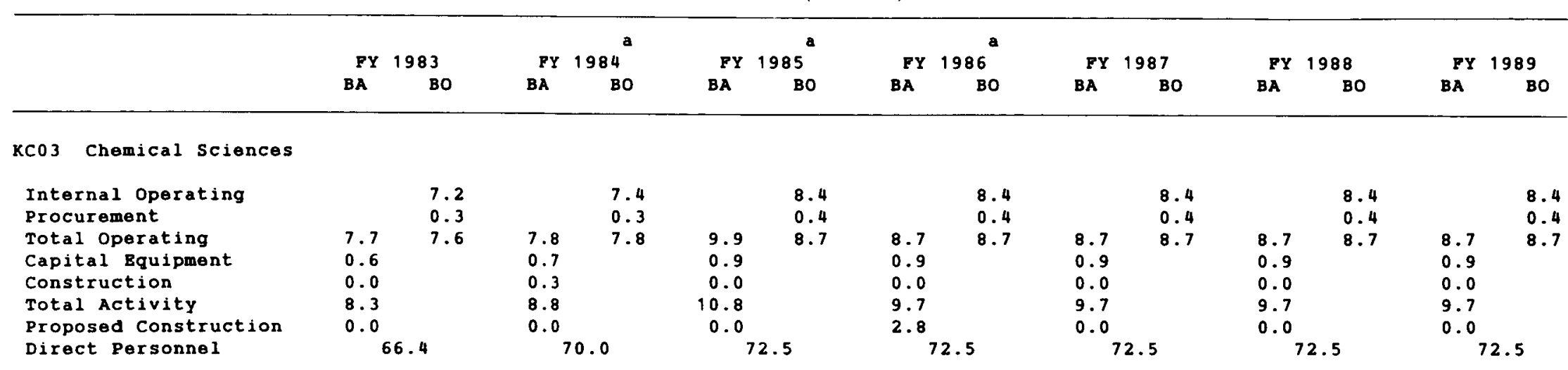

KC04 Engineering, Math, and Geosciences

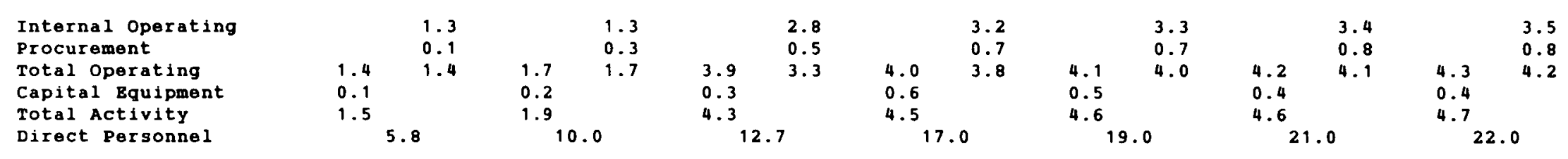

KC06 Biological Energy Research

\begin{tabular}{|c|c|c|c|c|c|c|c|c|c|c|c|c|c|c|}
\hline $\begin{array}{l}\text { Internal operating } \\
\text { Procurement }\end{array}$ & & $\begin{array}{l}0.2 \\
0.0\end{array}$ & & $\begin{array}{l}0.2 \\
0.0\end{array}$ & & $\begin{array}{l}0.2 \\
0.0\end{array}$ & & $\begin{array}{l}0.4 \\
0.0\end{array}$ & & $\begin{array}{l}0.5 \\
0.0\end{array}$ & & $\begin{array}{l}0.5 \\
0.0\end{array}$ & & $\begin{array}{l}0.5 \\
0.0\end{array}$ \\
\hline Total Operating & 0.2 & 0.2 & 0.2 & 0.2 & 0.3 & 0.2 & 0.4 & 0.4 & 0.5 & 0.5 & 0.5 & 0.5 & 0.5 & 0.5 \\
\hline Direct Personnel & \multicolumn{2}{|c|}{1.6} & \multicolumn{2}{|c|}{2.0} & \multicolumn{2}{|c|}{2.0} & \multicolumn{2}{|c|}{3.5} & \multicolumn{2}{|c|}{5.0} & \multicolumn{2}{|c|}{5.0} & \multicolumn{2}{|r|}{5.0} \\
\hline
\end{tabular}


Table SD.1 (continued)

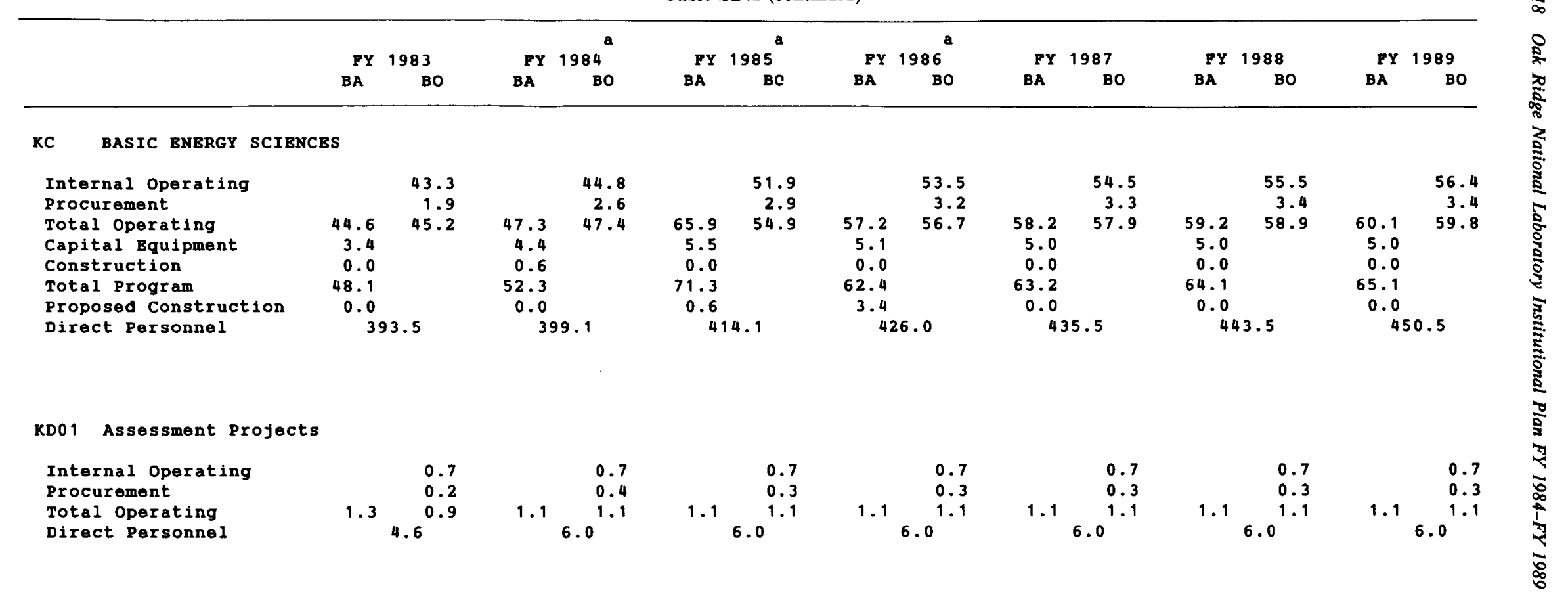

KD04 Advanced Technology Projects

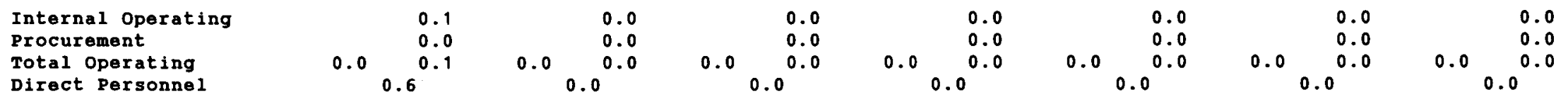


Table SD.1 (continued)

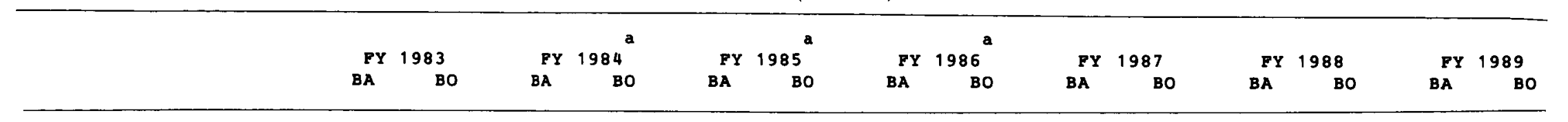

KD ENERGY RESGARCH AND ANALYSIS

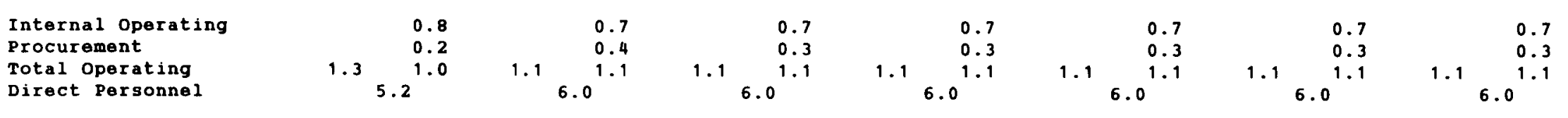

KB01 University Research Support : KB UNIVBRSITY RESEARCh SUPPORT

Internal Operating

Procurement

Total Operating

Direct Personnel

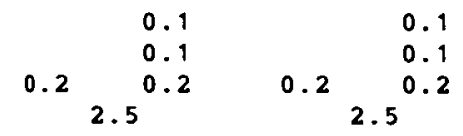

0.5
$0.25^{0.2}$

$2.5^{0.2}$
$0.2 \quad \begin{aligned} & 0.1 \\ & 2.5 \\ & 0.2\end{aligned}$

$0.2 \quad \begin{aligned} & 0.1 \\ & 0.1 \\ & 2.5\end{aligned}$

$0.2 \quad \begin{aligned} & 0.1 \\ & \\ & 2.5 \\ & 0.2\end{aligned}$

Office of Energy Research

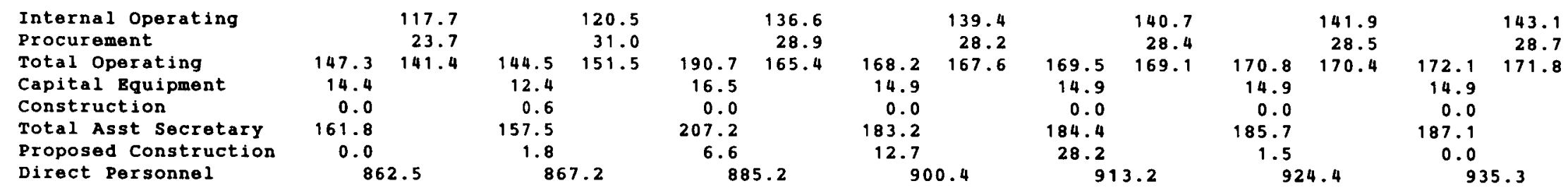


Table SD.1 (continued)

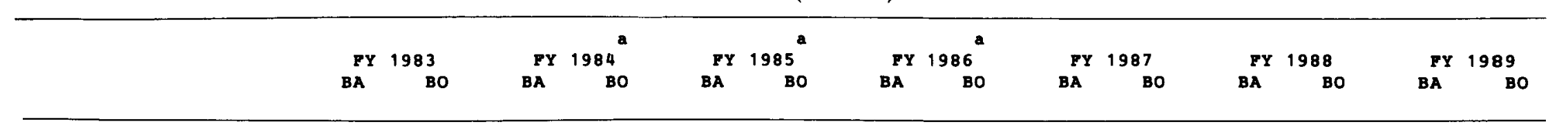

Assistant Secretary for Defense

AR05 Defense Waste Management Programs : AR DEFENSE WASTE MANAGEKENT

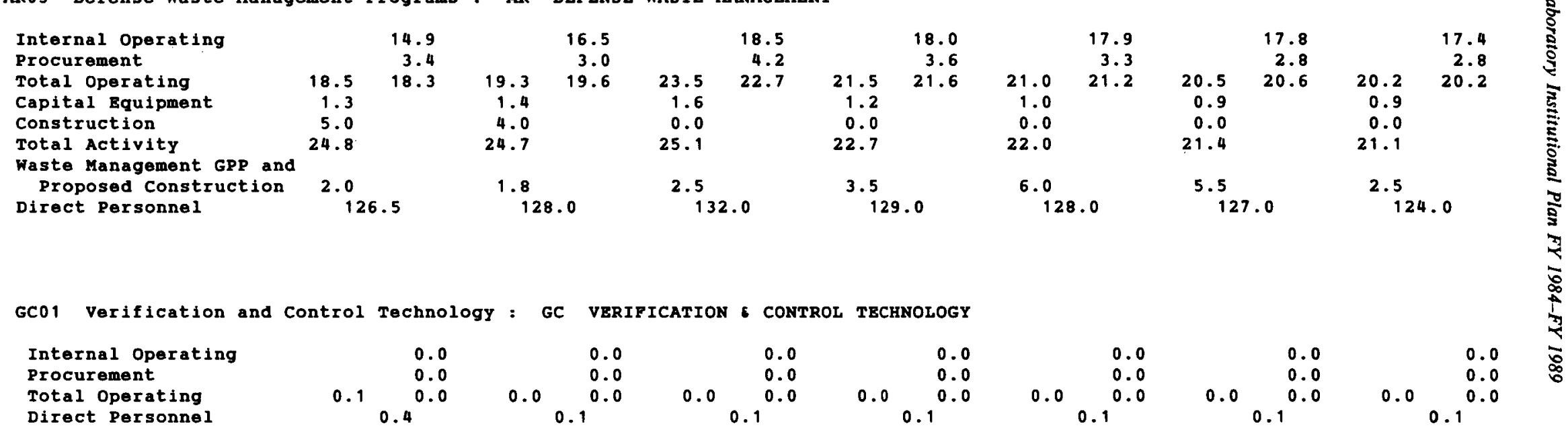

GD02 Nuclear Matls Security safeguards : GD NUCLEAR MATBRIALS SECURITY SAFEGUARDS

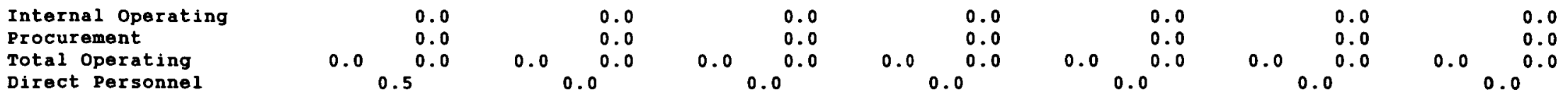


Table SD.1 (continued)

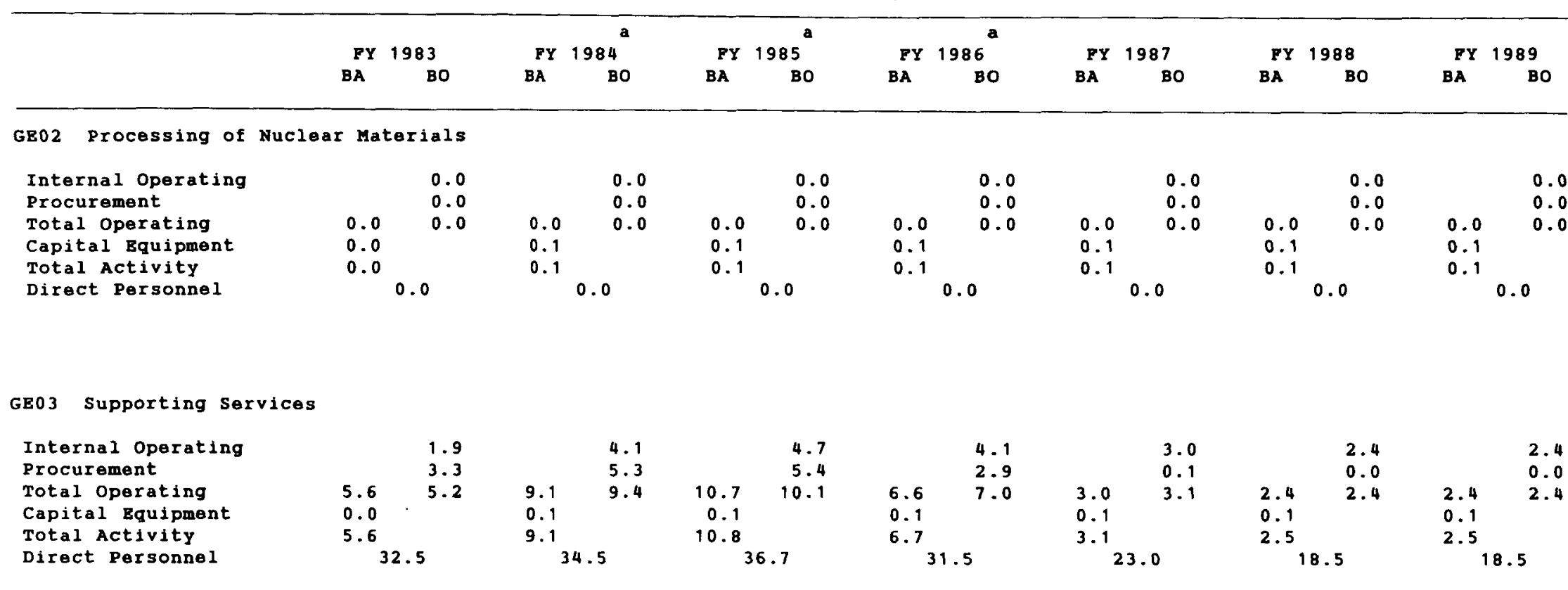

GE MATBRIALS PRODUCTION

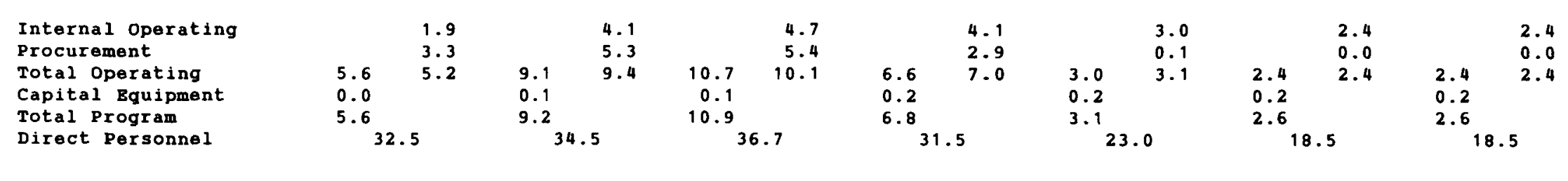


Table SD.1 (continued)

\begin{tabular}{|c|c|c|c|c|c|c|c|c|c|c|c|c|c|c|}
\hline & \multirow{2}{*}{\multicolumn{2}{|c|}{ FY 1983}} & \multirow{2}{*}{\multicolumn{2}{|c|}{ FY $1984^{a}$}} & \multirow{2}{*}{\multicolumn{2}{|c|}{ FY $1985^{a}$}} & \multicolumn{4}{|c|}{$\mathbf{a}$} & \multirow{2}{*}{\multicolumn{2}{|c|}{ FY 1988}} & \multirow{2}{*}{\multicolumn{2}{|c|}{ FY 1989}} \\
\hline & & & & & & & $\mathbf{F Y}$ & 986 & $\mathbf{F Y}$ & 987 & & & & \\
\hline & BA & BO & BA & BO & BA & Bo & BA & BO & BA & Bo & BA & BO & BA & Bo \\
\hline \multicolumn{15}{|c|}{ Assistant secretary for Defense } \\
\hline Internal Operating & & 16.9 & & 20.7 & & 23.2 & & 22.2 & & 20.9 & & 20.2 & & 19.8 \\
\hline Procurement & & 6.7 & & 8.3 & & 9.6 & & 6.5 & & 3.4 & & 2.8 & & 2.8 \\
\hline Total operating & 24.2 & 23.6 & 28. & 29.0 & 34.2 & 32.8 & 28.1 & 28.7 & 24.0 & 24.4 & 22.9 & 23.0 & 22.6 & 22.6 \\
\hline Capital Equipment & 1.3 & & 1. & 5 & 1.8 & & 1.4 & & 1.1 & & 1.1 & & 1.1 & \\
\hline Construction & 5.0 & & 4. & 0 & 0.0 & & 0.0 & & 0.0 & & 0.0 & & 0.0 & \\
\hline Total Asst secretary & 30.5 & & 34. & & 36.0 & & 29.5 & & 25.1 & & 24.0 & & 23.7 & \\
\hline $\begin{array}{l}\text { Waste Management GPP and } \\
\text { Proposed Construction }\end{array}$ & 2.0 & & 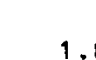 & 8 & 2.5 & & 3.5 & & 6.0 & & 5.5 & & 2.5 & \\
\hline Direct Personnel & & 159.9 & & 162.6 & 16 & 3.8 & & .6 & & .1 & & & & \\
\hline \multicolumn{15}{|c|}{ AS for Env.Protection, Safety Emerg. Prep } \\
\hline HA01 Environment, Safety & and & Health : & HA & BNVIRONME] & AL RES & \& DEVB & PMENT & & & & & & & \\
\hline Internal Operating & & 2.7 & & 1.5 & & 2.0 & & 2.0 & & 2.0 & & 2.0 & & 2.0 \\
\hline Procurement & & 1.0 & & 0.5 & & 0.5 & & 0.5 & & 0.5 & & 0.5 & & 0.5 \\
\hline Total Operating & 3.5 & 3.8 & 2.0 & 2.0 & 2.5 & 2.5 & 2.5 & 2.5 & 2.5 & 2.5 & 2.5 & 2.5 & 2.5 & 2.5 \\
\hline Capital Equipment & 0.1 & & 0. & & 0.1 & & 0.1 & & 0.1 & & 0.1 & & 0.1 & \\
\hline Total Activity & 3.6 & & 2. & & 2.6 & & 2.6 & & 2.6 & & 2.6 & & 2.6 & \\
\hline Direct Personnel & & 24.3 & & 10.0 & & .0 & & .0 & & .0 & & & & \\
\hline
\end{tabular}

UB02 POwer Supply and Reliability : UB UTILITY PROG \& REGULATORY INTERVEN

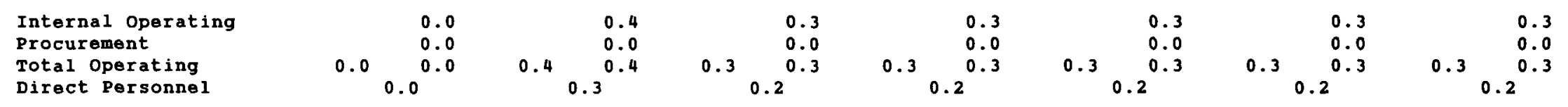


Table SD.1 (continued)

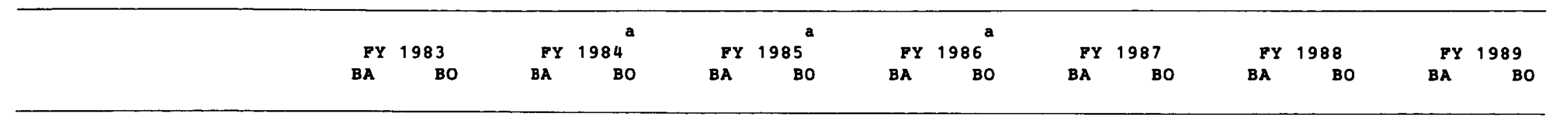

AS for Env Protection, Safety Emerg Prep

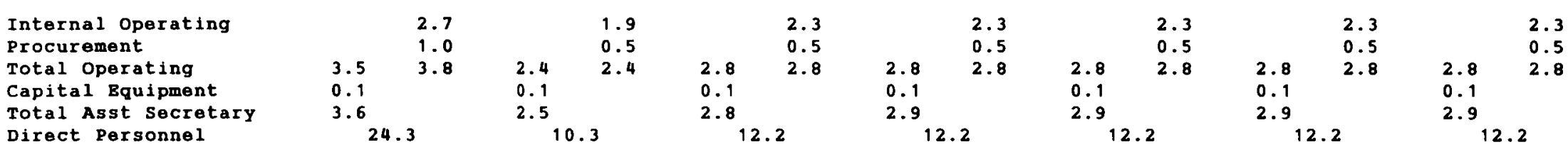

Pederal Energy Regulatory Commission

VP00 Other Bxpenses : VP OTHER EXPBNSES

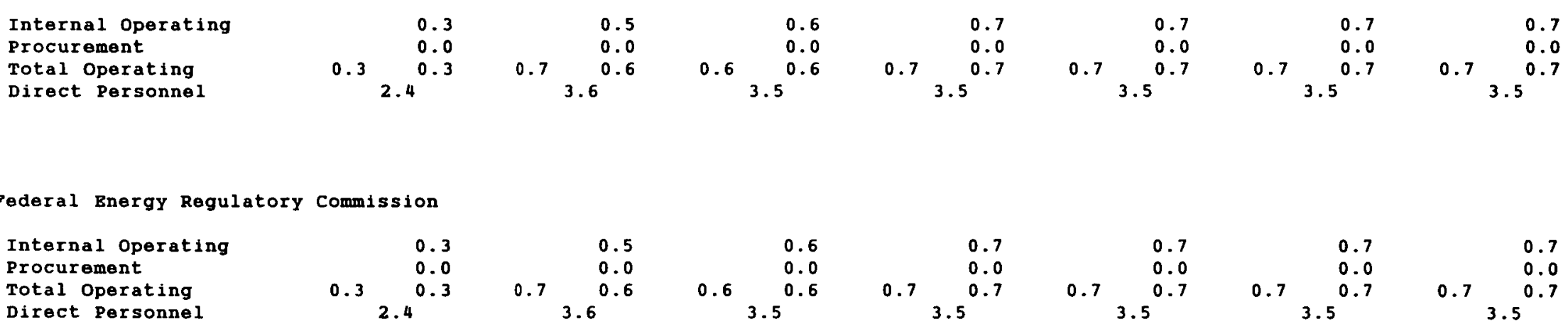

Total Operating

$2.4^{0.3}$

3.6

3.5

$3.5^{0.7}$

$3.5^{0.7}$

3.5 
Table SD.1 (continued)

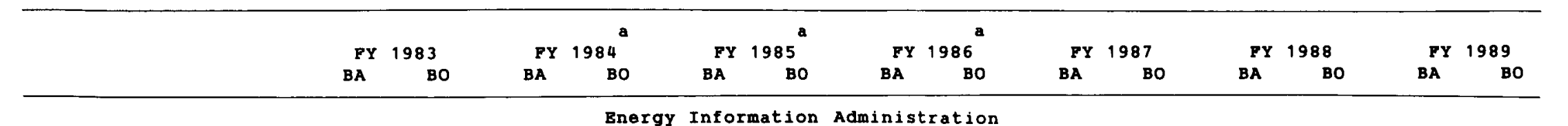

Energy Information Administration

TA01 Program Support : TA COLLECTION, PRODUCTION AND ANALYSIS

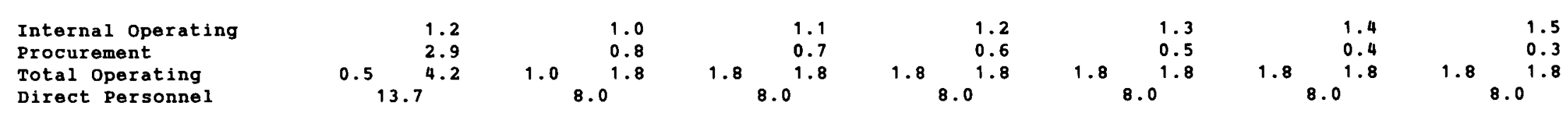

TB01 Program Services Support : TB PROGRAM SERVICES

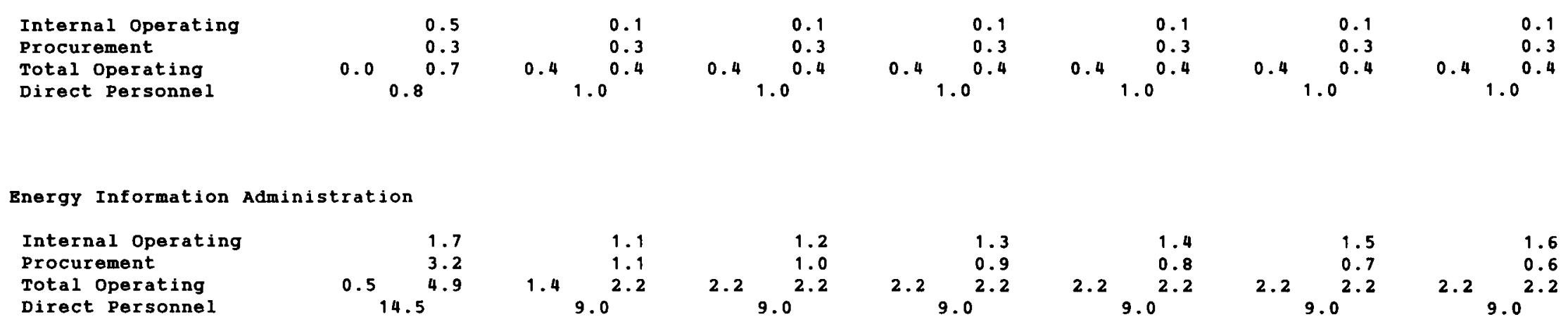


Table SD.1 (continued)

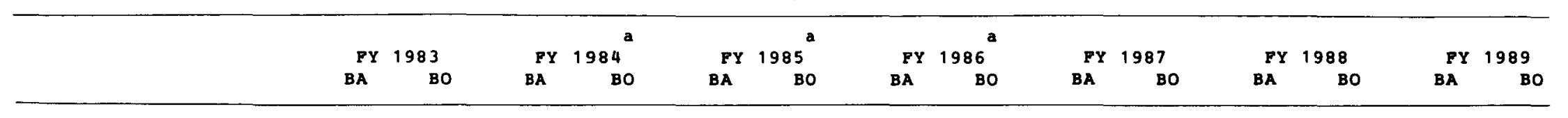

Asst. Sec. for Management Administration

LA01 Technical Information Center : LA TECHNICAL INFORMATION SERVICES

\begin{tabular}{|c|c|c|c|c|c|c|c|c|c|c|c|c|c|c|}
\hline $\begin{array}{l}\text { Internal operating } \\
\text { Procurement }\end{array}$ & & $\begin{array}{l}0.8 \\
0.0\end{array}$ & & $\begin{array}{l}1.0 \\
0.0\end{array}$ & & $\begin{array}{l}1.2 \\
0\end{array}$ & & $\begin{array}{l}1.2 \\
0\end{array}$ & & $\begin{array}{l}1.3 \\
0\end{array}$ & & $\begin{array}{l}1.3 \\
0.0\end{array}$ & & $\begin{array}{l}1.4 \\
0.0\end{array}$ \\
\hline Total Operating & 0.9 & 0.8 & 1.1 & 1.0 & 1.2 & 1.2 & 1.3 & 1.2 & 1.3 & 1.3 & 1.4 & 1.3 & 1.4 & 1.4 \\
\hline Capital Bquipment & 0.1 & & 0.1 & & 0.1 & & 0.0 & & 0.0 & & 0.0 & & 0.0 & \\
\hline Total Activity & 1.0 & & 1.2 & & 1.3 & & 1.3 & & 1.3 & & 1.4 & & 1.4 & \\
\hline Direct Personnel & & & & & & & & & & & & & & \\
\hline
\end{tabular}

WBOO In-House Energy Management : WB IN-HOUSE ENBRGY MANAGEMENT

\begin{tabular}{|c|c|c|c|c|c|c|c|c|c|c|c|c|c|c|}
\hline Internal operating & & 0.1 & & 0.0 & & 0.0 & & 0.0 & & 0.0 & & 0.0 & & 0.0 \\
\hline Procurement & & 0.0 & & 0.0 & & 0.0 & & 0.0 & & 0.0 & & 0.0 & & 0.0 \\
\hline Total Operating & 0.0 & 0.1 & 0.0 & 0.0 & 0.0 & 0.0 & 0.0 & 0.0 & 0.0 & 0.0 & 0.0 & 0.0 & 0.0 & 0.0 \\
\hline Energy Conservation GPP & 1.5 & & 2.0 & & 2.0 & & 2.0 & & 2.0 & & 1.5 & & 1.0 & \\
\hline Direct Personnel & & & & & & & & & & & & & & \\
\hline
\end{tabular}

Asst. Sec. for Management Administration

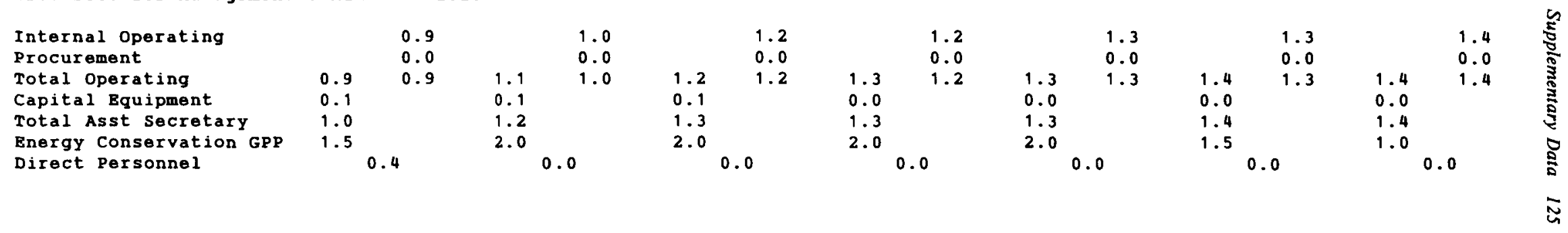


Table SD.1 (continued)

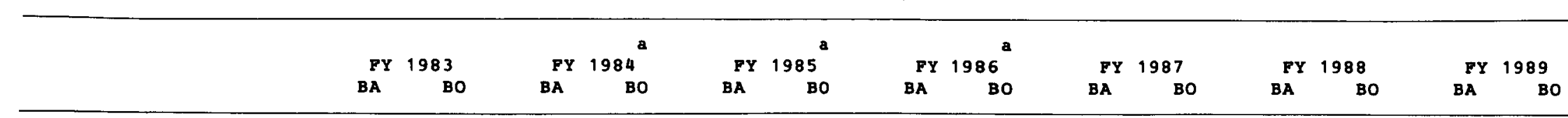

DOE CONTRACTORS OPERATIONS OFFICE

DOE CONTRACTORS OPERATIONS OFFICE

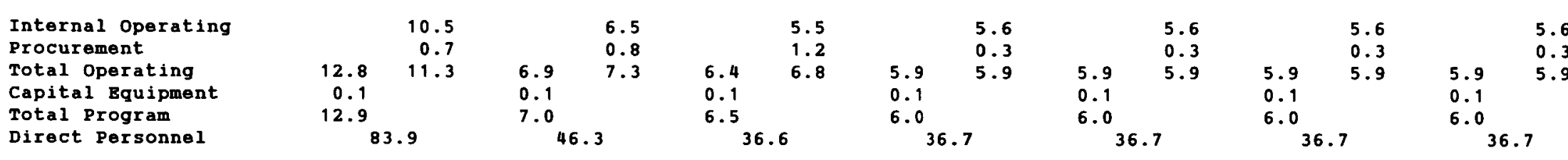

Work for others

NRC/Nuclear Reactor Regulation

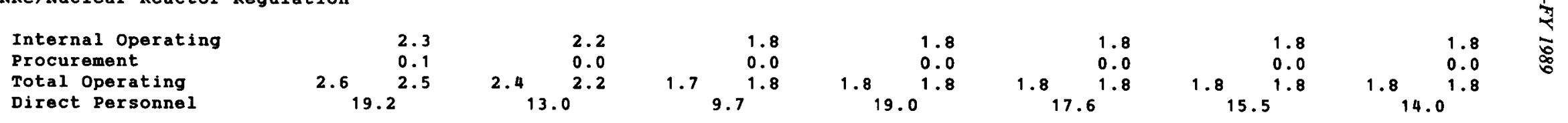

\section{NRC/Administration}

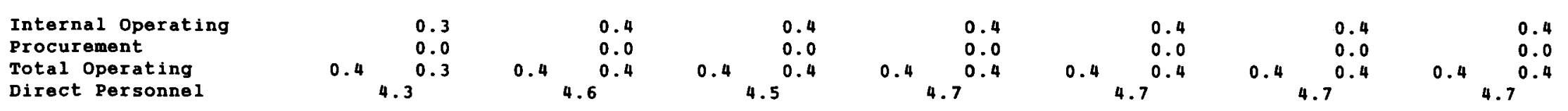


Table SD.1 (continued)

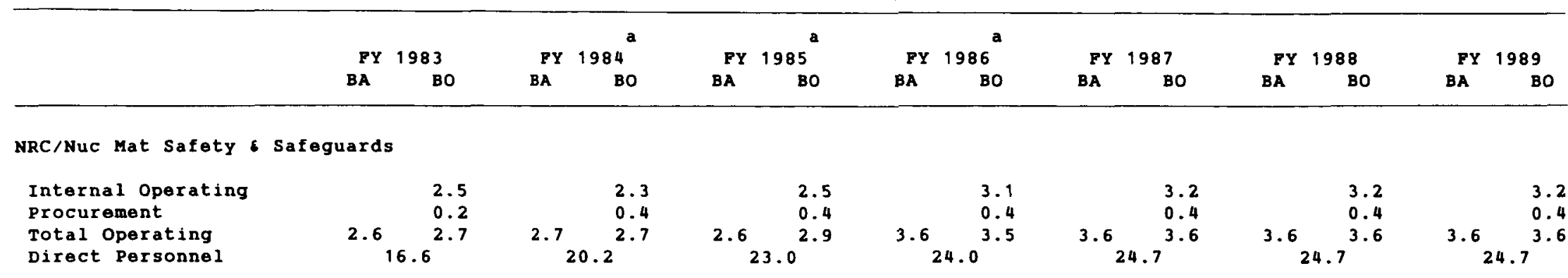

NRC/Nuclear Regulatory Research

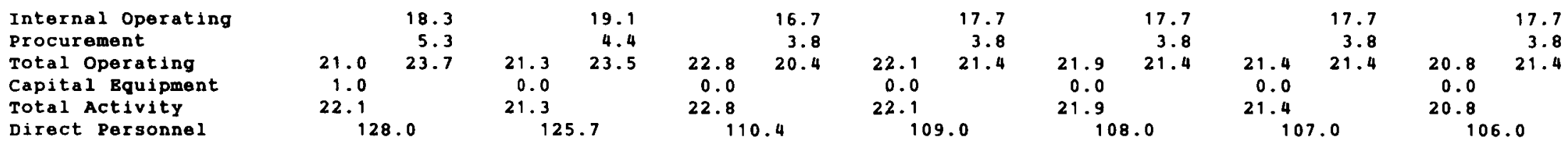

NRC/Analysis Eval of Oper Data

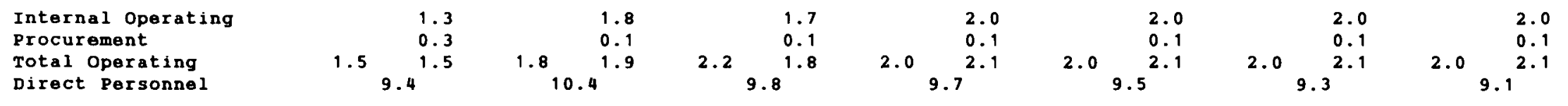


Table SD.1 (continued)

\begin{tabular}{|c|c|c|c|c|c|c|c|c|c|c|c|c|c|c|}
\hline & $\begin{array}{c}\text { PY } \\
\text { BA }\end{array}$ & $\begin{array}{l}983 \\
\text { BO }\end{array}$ & $\begin{array}{l}\text { FY } \\
\text { BA }\end{array}$ & $\begin{array}{c}984^{\mathrm{a}} \\
\mathrm{BO}\end{array}$ & $\begin{array}{c}\mathbf{F Y} \\
\mathbf{B A}\end{array}$ & $985^{a}$ & $\underset{B A}{\mathbf{F Y}}$ & $86^{a}$ & $\begin{array}{c}\text { FY } \\
\text { BA }\end{array}$ & $\begin{array}{l}87 \\
\text { BO }\end{array}$ & $\begin{array}{c}\mathbf{F Y} \\
\mathbf{B A}\end{array}$ & $\begin{array}{l}988 \\
\text { BO }\end{array}$ & $\begin{array}{c}\text { PY } \\
\text { BA }\end{array}$ & $\begin{array}{r}1989 \\
\text { BO }\end{array}$ \\
\hline \multicolumn{15}{|l|}{ NRC/Other offices } \\
\hline $\begin{array}{l}\text { Internal Operating } \\
\text { Procurement } \\
\text { Total Operating } \\
\text { Direct Personnel }\end{array}$ & 0.7 & $\begin{array}{r}0.4 \\
0.0 \\
0.4 \\
.5\end{array}$ & 1.0 & $\begin{array}{r}1.0 \\
0.0 \\
.3^{1.0}\end{array}$ & 1.6 & $\begin{array}{r}1.6 \\
0.0 \\
1.6\end{array}$ & 1.6 & $\begin{array}{r}1.6 \\
0.0 \\
1.6\end{array}$ & 1.6 & $\begin{array}{r}1.6 \\
0.0 \\
1.6 \\
2^{1.6}\end{array}$ & 1.6 & $\begin{array}{l}1.6 \\
0.0 \\
1.6\end{array}$ & 1.6 & $\begin{array}{r}1.6 \\
0.0 \\
1.6\end{array}$ \\
\hline \multicolumn{15}{|c|}{ NUCLEAR REGULATORY COMMISSION } \\
\hline $\begin{array}{l}\text { Internal operating } \\
\text { Procurement } \\
\text { Total operating } \\
\text { Capital Bquipment } \\
\text { Total Program } \\
\text { Direct Personnel }\end{array}$ & $\begin{array}{r}28.9 \\
1.1 \\
30.0 \\
17\end{array}$ & $\begin{array}{r}25.2 \\
5.9 \\
31.1\end{array}$ & $\begin{array}{r}29.6 \\
0.0 \\
29.6 \\
18\end{array}$ & $\begin{array}{r}26.8 \\
4.9 \\
31.7\end{array}$ & $\begin{array}{r}31.4 \\
0.0 \\
31.4 \\
16\end{array}$ & $\begin{array}{r}24.7 \\
4.3 \\
28.9\end{array}$ & $\begin{array}{r}31.5 \\
0.0 \\
31.5 \\
17\end{array}$ & $\begin{array}{r}26.6 \\
4.2 \\
30.8\end{array}$ & $\begin{array}{r}31.3 \\
0.0 \\
31.3 \\
17\end{array}$ & $\begin{array}{r}26.6 \\
4.2 \\
30.9\end{array}$ & $\begin{array}{r}30.8 \\
0.0 \\
30.8 \\
17\end{array}$ & $\begin{array}{r}26.6 \\
4.2 \\
30.9\end{array}$ & $\begin{array}{r}30.2 \\
0.0 \\
30.2 \\
16\end{array}$ & $\begin{array}{r}26.6 \\
4.2 \\
30.9 \\
\\
77.7\end{array}$ \\
\hline \multicolumn{15}{|l|}{ DEPARTMENT OF DEFENSE } \\
\hline $\begin{array}{l}\text { Internal Operating } \\
\text { Procurement } \\
\text { Total operating } \\
\text { Capital Equipment } \\
\text { Total Program } \\
\text { Direct Personnel }\end{array}$ & $\begin{array}{l}7.7 \\
0.1 \\
7.7\end{array}$ & $\begin{array}{l}5.4 \\
2.3 \\
7.7\end{array}$ & $\begin{array}{r}20.8 \\
1.9 \\
22.7 \\
8\end{array}$ & $\begin{array}{r}8.7 \\
6.8 \\
15.5\end{array}$ & $\begin{array}{r}25.6 \\
2.5 \\
28.1 \\
9\end{array}$ & $\begin{array}{l}11.1 \\
10.2 \\
21.3\end{array}$ & $\begin{array}{r}26.0 \\
1.6 \\
27.6 \\
9\end{array}$ & $\begin{array}{l}11.4 \\
12.7 \\
24.0\end{array}$ & $\begin{array}{r}26.5 \\
1.5 \\
28.0 \\
9\end{array}$ & $\begin{array}{l}12.1 \\
13.5 \\
25.5\end{array}$ & $\begin{array}{r}26.5 \\
1.5 \\
28.0 \\
9\end{array}$ & $\begin{array}{l}13.1 \\
13.5 \\
26.5\end{array}$ & $\begin{array}{r}26.5 \\
1.5 \\
28.0 \\
9\end{array}$ & $\begin{array}{l}13.1 \\
13.5 \\
26.5\end{array}$ \\
\hline
\end{tabular}


Table SD.1 (continued)

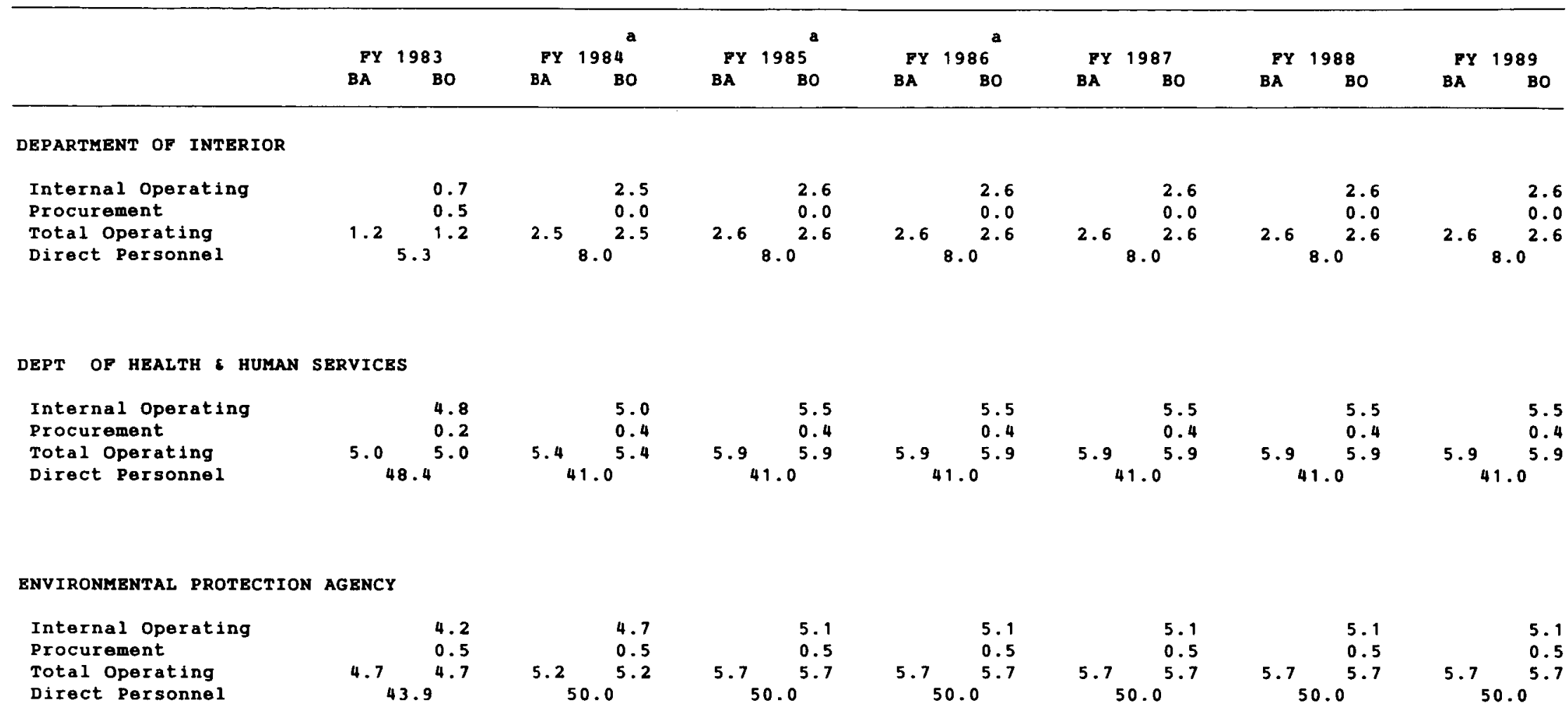


Table SD.1 (continued)

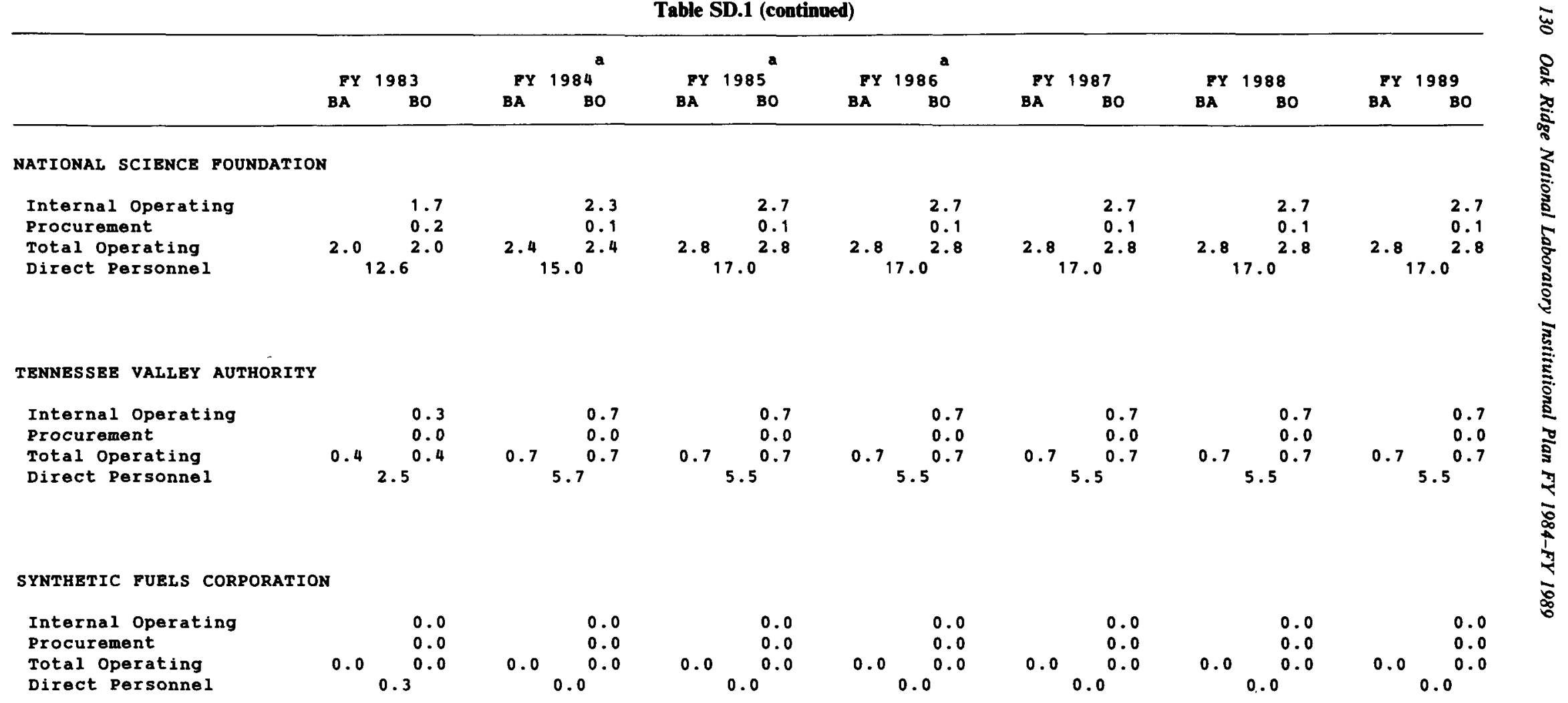


Table SD.1 (continued)

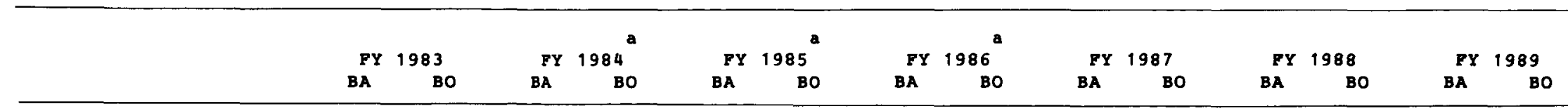

\section{OTHER FEDERAL AGENCIES}

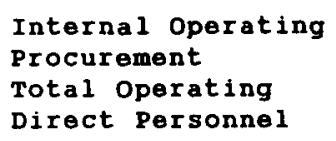

Internal operating

Procurement

Total Operating

Direct Personnel

\begin{tabular}{|c|c|c|c|}
\hline & $\begin{array}{l}3.0 \\
0.4\end{array}$ & & $\begin{array}{l}5.9 \\
0.7\end{array}$ \\
\hline .5 & 3.5 & 6.6 & 6.6 \\
\hline
\end{tabular}

$6.3 \quad \begin{array}{r}6.0 \\ 6.3 \\ 6.9^{6.3}\end{array}$

$6.1 r_{36.9}^{6.0} \begin{aligned} & 6.1 \\ & 6.1\end{aligned}$

6.0
$6.1 \quad 6.1$
36.9

$6.1 \quad \begin{array}{r}6.0 \\ 0.1 \\ 36.9^{6.1}\end{array}$

$5.9{ }_{35.6} \begin{aligned} & 5.8 \\ & 5.9\end{aligned}$

ELECTRIC POWER RESEARCH INSTITUTE

Internal operating

procurement

Total Operating

$\begin{array}{llll} & 1.8 & & 2.2 \\ & 0.4 & & 0.3 \\ 2.2 & 2.2 & 2.5 & 2.5\end{array}$

$2.5 r_{17.0}^{2.2} \begin{aligned} & 0.3 \\ & 2.5\end{aligned}$

$3.0 \quad \begin{array}{r}2.7 \\ 0.3 \\ 17.0^{3.0}\end{array}$

$3.0 \quad \begin{array}{r}2.7 \\ 17.0^{3.0}\end{array}$

$3.0 \begin{array}{r}2.7 \\ 0.3 \\ 17.0^{3.0}\end{array}$

$\begin{array}{rr}2.7 \\ 17.0 & 0.3 \\ 3.0\end{array}$

OTHER NONPEDERAL AGENCIES

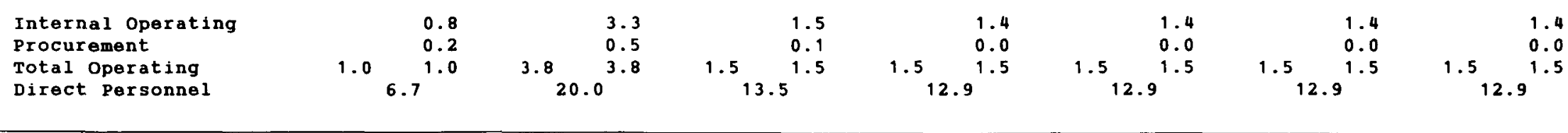

Escalation factors from FY 1983 to FY 1984 and from FY 1984 to FY 1985 are both $8.5 \times$. Figures for FY 1986 through FY 1989 are in constant PY 1985 dollars. 
Table SD.2. WPAS cross reference ${ }^{a}$

\begin{tabular}{|c|c|c|}
\hline B\& $R$ code & WPAS No. & WPAS title \\
\hline & Assistant & secretary for Fossil Energy \\
\hline \multirow[t]{3}{*}{ AA0515000 } & 00211 & FE Solid Waste Extractions \\
\hline & 00241 & Pgm Plan Fos En Solid Wastes \\
\hline & 00270 & Metals from Fly Ash-Process Eval \\
\hline \multirow[t]{3}{*}{ AA0 520000} & 00253 & Coal Beneficiation: Novel Flotation \\
\hline & 00279 & System Analysis of Coal Prep \\
\hline & 99999 & Unassigned Uncosted Bal $9 / 30 / 82$ \\
\hline AA 1505000 & 00157 & Ceramic HX for FF Comb \\
\hline AA 1510100 & 00028 & ARETD Fossil Energy Mtls Program \\
\hline \multirow[t]{4}{*}{ AA 1515050} & 00231 & FFFB Bioreactors for Coal Wastewate \\
\hline & 00268 & Control of Reverse Osmosis \\
\hline & 00269 & Solids and Sludge Disposal \\
\hline & 99999 & Unassigned Uncosted Bal $9 / 30 / 82$ \\
\hline \multirow[t]{5}{*}{ AA 1515100} & 00084 & Process Research Digest \\
\hline & $\begin{array}{l}00208 \\
00209\end{array}$ & $\begin{array}{l}\text { Process Factors Affecting sCT Prodn } \\
\text { Slurry Reactor Development }\end{array}$ \\
\hline & 00302 & New Liquefaction Techniques \\
\hline & 00305 & Physical Properties of Coal Liquids \\
\hline & $\mathrm{A} 0208$ & Process Factors Affecting scT Prodn \\
\hline \multirow[t]{9}{*}{ AA 1520150} & 00205 & GEMS/Liquid-Gaseous Fuel Supplies \\
\hline & 00213 & Liquefaction ECT Assessments \\
\hline & 00223 & Regulatory/Update (Newsletter) \\
\hline & 00227 & Liq Econ $\varepsilon$ Tech Assmts \\
\hline & 00228 & FE Envir Safety \& Health \\
\hline & 00265 & Pseudo Comp Prop for ASPEN \\
\hline & 00311 & IEA - EA Service \\
\hline & 00316 & Systems Analysis Support - DLTAS \\
\hline & 00324 & Performance Assurance $\varepsilon$ stand \\
\hline \multirow[t]{4}{*}{ AA2515150 } & 00262 & Matls for Coal Liqu p-Vessels \\
\hline & 00263 & Coal Liqu Matls Test \& Fail \\
\hline & 00272 & Coating studies for Coal Conversion \\
\hline & 00280 & CvD coating studies \\
\hline \multirow[t]{6}{*}{ AA2530100 } & 00216 & Eff of Hydrotreat $\varepsilon$ Mitig Processes \\
\hline & 00220 & On-Line Monitor-ESR \\
\hline & 00222 & Liq plant studies - Components \\
\hline & 00239 & LIQUEFACTION COMPONENTS STUDIES \\
\hline & 00255 & Fluid Props. for Coal Conversion \\
\hline & 00258 & SCT Process Liquids properties \\
\hline AA3505400 & 00017 & Coal Combustor for cogenerat \\
\hline AA3505500 & 00273 & Mag Benef of FBC streams \\
\hline \multirow[t]{5}{*}{ AA 3520100} & 00274 & Combustion Kinetics of AFB Fuels \\
\hline & 00275 & Coupled FBC Pyrolysis Pwr sys \\
\hline & 00276 & High Performance PFBC Dev \\
\hline & 00277 & Risk Assessment of PFBC \\
\hline & 00278 & PFBC Deposition Experiment \\
\hline AA3525050 & 00326 & systems assessment of PFBC \\
\hline AA5505050 & 00159 & Dist Heating - Fossil Energy \\
\hline AA5515150 & 00011 & Low-Temperature Heat Utilization \\
\hline \multirow[t]{2}{*}{ AA8 540000} & 00210 & IEA Tech Rep \\
\hline & 00259 & Purification of SNG \\
\hline \multirow[t]{2}{*}{ AA8545050 } & 00232 & slurry Pump Development \\
\hline & 00233 & Hot Dirty Gas Heat Exchangers \\
\hline
\end{tabular}


Table SD.2 (continued)

\begin{tabular}{|c|c|c|}
\hline B \& $R$ code & WPAS No. & WPAS title \\
\hline & 00234 & Hot Dirty Gas Compressors/Expanders \\
\hline & 00235 & Hot Dirty Gas Valves \\
\hline & 00236 & Plant Component support \\
\hline & 00238 & Critical Component Tech. Assmt. \\
\hline & 00281 & NDT Needs for Gasification \\
\hline & A0218 & Adv Pres Vessel Matl Technology \\
\hline & A0219 & Plant Matls Surveillance Tests \\
\hline & B0218 & Electroslag Component Casting \\
\hline & E0218 & Nondestructive Test Ultrasonic \\
\hline & $E 0219$ & Plant Materials support \\
\hline & MO218 & Mgmt Surface Gasif Matls Prog \\
\hline AA 8550050 & 00237 & Gasifiers in Industry, EHES \\
\hline$A C 1510100$ & 00087 & Amphiphiles in EOR \\
\hline \multirow[t]{2}{*}{$\mathrm{CHO} 203000$} & 00203 & METC Modeling Support \\
\hline & Assistant & Secretary for Nuclear Energy \\
\hline AE2 2005100 & 99999 & Unassigned Uncosted Balance $9 / 30 / 82$ \\
\hline \multirow[t]{4}{*}{ AE2 2005150} & SNRO 1 & Space Nuclear Reactor studies \\
\hline & SR005 & Alternative Heat Pipe Development \\
\hline & SR006 & Heat Pipe Heater Development \\
\hline & SR007 & Heat Pipe Alloy Development \\
\hline AE2010050 & 01322 & Space Flight Systems Hardware \\
\hline AE2015050 & 99999 & Unassigned Uncosted Balance $9 / 30 / 82$ \\
\hline AE2015100 & 01311 & Small Reactor Evaluation \\
\hline AE2081050 & 00000 & Other Spec Matls-Iridium Change \\
\hline AF 1015000 & 99999 & Unassigned Uncosted Balance $9 / 30 / 82$ \\
\hline AF 1025000 & 99999 & Unassigned Uncosted Balance $9 / 30 / 82$ \\
\hline \multirow[t]{4}{*}{ AF 1520000} & $01311 \mathrm{D}$ & Small Reactor Eval-Program Plan \\
\hline & $01312 \mathrm{~A}$ & Elec Utility Industry-Region study \\
\hline & $01447 \mathrm{~K}$ & Technical support \\
\hline & $01448 \mathrm{~A}$ & Energy Economic Data Base \\
\hline AF 1540101 & OHO16 & Measurements $\varepsilon$ Controls Technology \\
\hline AF 1540102 & OH 037 & Clad/Duct Development \\
\hline \multirow[t]{10}{*}{ AF 1540103} & OR 1.1 & High-Temp Structural Design Tech \\
\hline & OR 1.10 & MSTMC Development \\
\hline & OR 1.2 & Seismic Design Tech \\
\hline & OR 1.3 & Mech Props Design Data \\
\hline & OR 1.4 & Fabrication Technology \\
\hline & OR 1.5 & NDT Technology \\
\hline & OR 1.7 & Advanced Alloy Development \\
\hline & OR 1.7 .3 & Advanced Alloy Design Methods \\
\hline & OR 1.8 .2 & Documentation \\
\hline & OR 1.8 .3 & Nuclear systems Materials Handbook \\
\hline \multirow[t]{6}{*}{ AF 1540104} & OHOO4 & Fast Shielding Experimental Prog \\
\hline & OHO13 & cross sections for Reactor Mtls \\
\hline & ОН 015 & Radiation Shielding Info Center \\
\hline & OH 054 & Assess of Reactor Parameter Uncert \\
\hline & OH 057 & Shielding Analysis \\
\hline & OH 153 & US/UK Actinide Irradiations \\
\hline \multirow[t]{3}{*}{ AF 1540105} & $\mathrm{OH} 020$ & RED Integration \\
\hline & OH044 & LOA-2 THORS \\
\hline & OH 136 & LOA-4 Environment \\
\hline
\end{tabular}


Table SD.2 (continued)

\begin{tabular}{|c|c|c|}
\hline B\&R code & WPAS No. & WPAS title \\
\hline \multirow[t]{6}{*}{ AF 1540303} & $01311 \mathrm{E}$ & Small Reactor Eval-Program Support \\
\hline & $01312 \mathrm{E}$ & Electric utility Indust-Region stu \\
\hline & $01447 \mathrm{~J}$ & Age Profile of Power Plants \\
\hline & 01501 & Breeder strategy studies support \\
\hline & 99999 & Unassigned Uncosted Balance $9 / 30 / 82$ \\
\hline & ONLWIO 06 & Integrated Data Base Program \\
\hline \multirow{11}{*}{$\begin{array}{l}\text { AF } 1540352 \\
\text { AF } 1540836 \\
\text { AG2 } 520000\end{array}$} & $\mathrm{OH} 022$ & Nuclear standards Management Center \\
\hline & 00000 & Breeder Reactor-TSF Fuel Change \\
\hline & 01329 & HTGR Chemistry studies \\
\hline & 01330 & Fueled Graphite Development \\
\hline & 01331 & structural Component Testing \\
\hline & 01332 & HTR Materials studies \\
\hline & 01333 & HTGR Graphite studies \\
\hline & 01334 & HTR Shielding \\
\hline & 01335 & HTR Physics \\
\hline & 01336 & HTR Assessments \\
\hline & 01338 & HTR CFTL studies \\
\hline AG 3005000 & ORTMI 01 & TMI Technical support' \\
\hline AG 3010000 & 99999 & Unassigned Uncosted Balance $9 / 30 / 82$ \\
\hline \multirow[t]{4}{*}{$\begin{array}{l}\text { AG3610000 } \\
A G 3620000\end{array}$} & $\begin{array}{l}99999 \\
01311 \mathrm{~A}\end{array}$ & $\begin{array}{l}\text { Unassigned Uncosted Balance } 9 / 30 / 82 \\
\text { Small Reactor Eval-Base Program }\end{array}$ \\
\hline & 01312 & Utility Deregulation study \\
\hline & $01447 \mathrm{~L}$ & Technical Support for NE Plans and \\
\hline & 01448 & Energy Economic Data Base \\
\hline \multirow[t]{2}{*}{ AH 1005000} & ONLWF 02 & FUSRAP support \\
\hline & ONLWIO 7 & Integrated Data Base Program \\
\hline АH 1010000 & $01312 \mathrm{~F}$ & Electric utility Industry-Regional \\
\hline AH 1015000 & $01312 \mathrm{~B}$ & Electric utility Industry-Regional \\
\hline \multirow[t]{4}{*}{ AH 1020000} & ONLWDO9 & Commercial surplus Fac surveil \\
\hline & ONLWD 14 & Disposition Planning \\
\hline & ONLWD 15 & Molten Salt Reac Decomm \\
\hline & ONLWIO 8 & Integrated Data Base Program \\
\hline AJ 0581030 & 00000 & All Other Inventories-Hafnium Chang \\
\hline AP 0515150 & ONLWI 05 & ORIGEN2 WOrk \\
\hline AP 0515250 & ONLWRO2 & Commercial waste Transport studies \\
\hline \multirow[t]{3}{*}{ AP0 520150} & $01312 \mathrm{C}$ & Electric Utility Industry-Regional \\
\hline & 99999 & Unassigned Uncosted Balance $9 / 30 / 82$ \\
\hline & ONLWL 48 & Maxey Flats Project \\
\hline AS 0500000 & ONLWIO9 & Integrated Data Base Program \\
\hline \multirow[t]{5}{*}{ AS 1505000} & $01311 \mathrm{~B}$ & Small Reactor Eval-utility \\
\hline & $01312 \mathrm{G}$ & Electric Utility Industry-Region st \\
\hline & $01447 \mathrm{G}$ & Technical support for NE Plans and \\
\hline & $01448 \mathrm{~B}$ & Energy Economic Data Base \\
\hline & CFR 1 & Breeder Reprocessing \\
\hline AS 1525100 & CFR2 & Thorium Fuel Cycle Reprocessing \\
\hline AS2505000 & 99999 & Unassigned Uncosted Balance $9 / 30 / 82$ \\
\hline AS2510000 & 99999 & Unassigned Uncosted Balance $9 / 30 / 82$ \\
\hline \multirow[t]{2}{*}{ AS 2515000} & $01448 \mathrm{C}$ & Energy Economic Data Base \\
\hline & 99999 & Unassigned Uncosted Balance $9 / 30 / 82$ \\
\hline CD 1001228 & $01311 \mathrm{C}$ & Small Reactor Eval-Multi-Unit \\
\hline \multirow[t]{3}{*}{ CD 1001232} & $01311 \mathrm{~F}$ & Small Reactor Eval-utility contact \\
\hline & $01312 \mathrm{D}$ & Electric Utility Industry -Region s \\
\hline & $01447 \mathrm{I}$ & Tech support for NE Plans and Eval \\
\hline
\end{tabular}


Table SD.2 (continued)

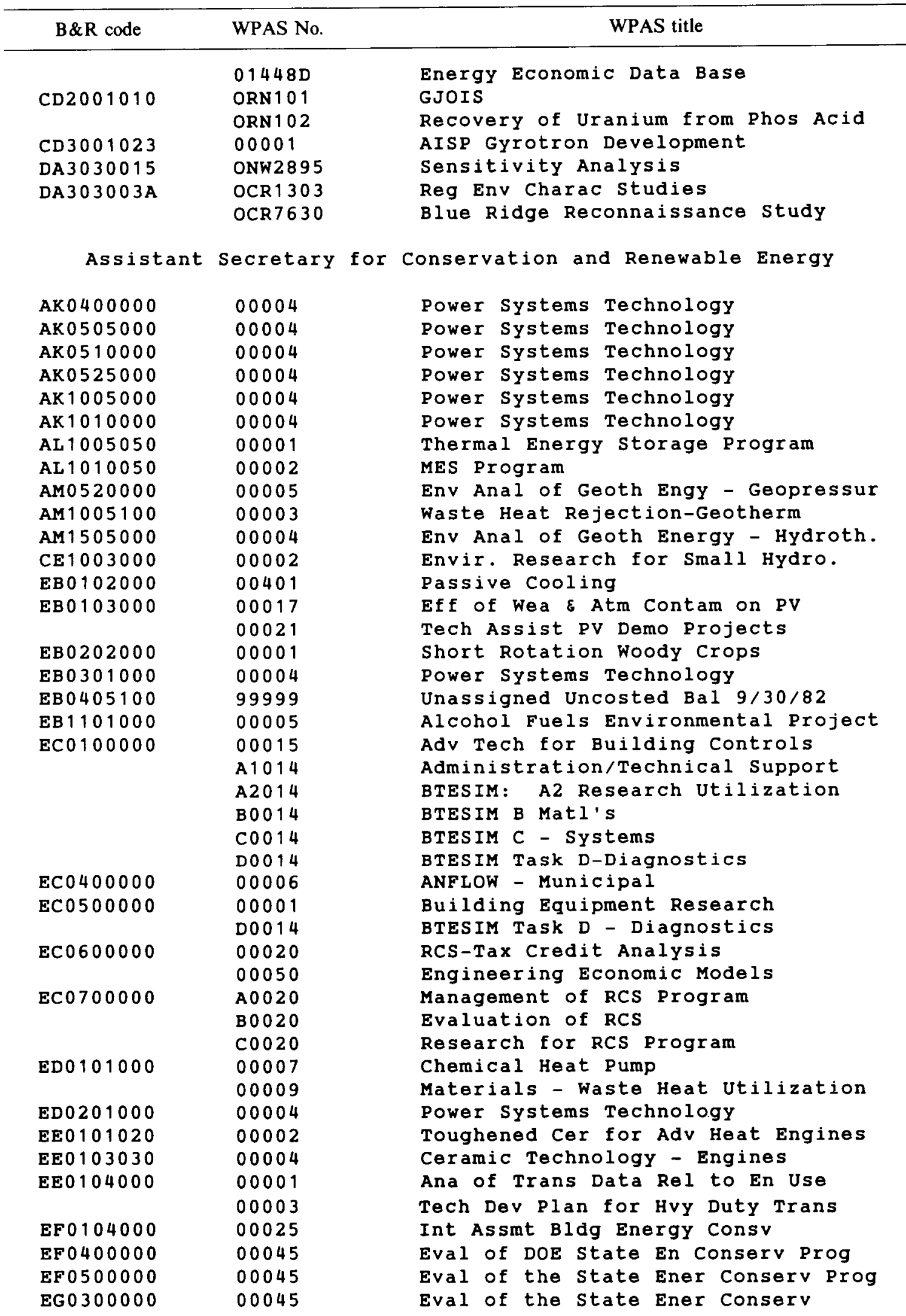


Table SD.2 (continued)

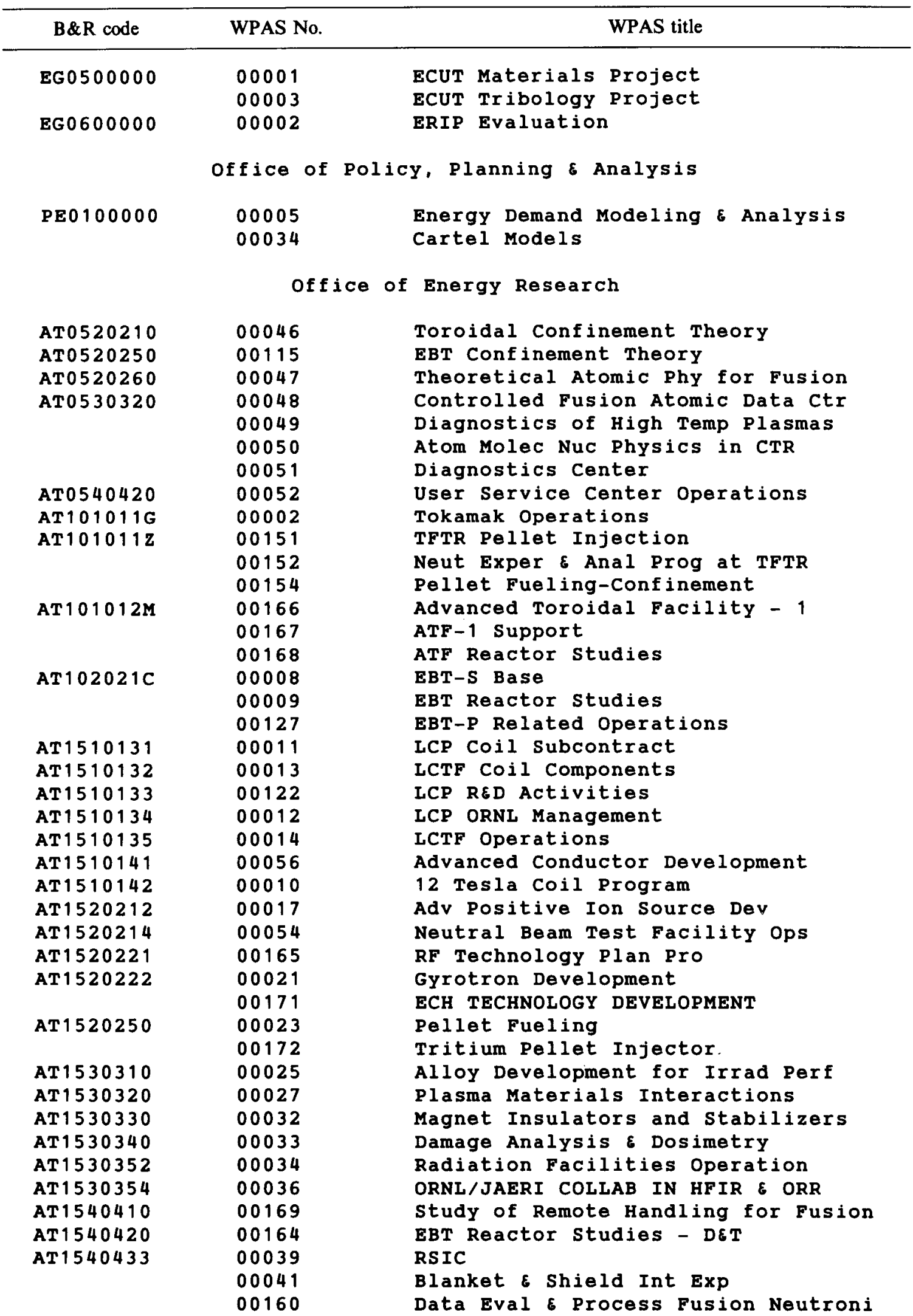


Table SD.2 (continued)

\begin{tabular}{|c|c|c|}
\hline B\&R code & WPAS No. & WPAS title \\
\hline AT 1540450 & 00044 & Plasma Systems Analysis (Tokamak) \\
\hline AT1550510 & 00043 & Magnetic Fusion Env Assess Prog \\
\hline AT1581011 & 00000 & Fuels Fabrication-ORR Change \\
\hline AT 1581020 & 00000 & Common Use Stores-Change \\
\hline AT 1581030 & 00000 & OSM-Precious Metals-Change \\
\hline AT1581040 & 00000 & Chg in Collat Funds $\&$ other Dep \\
\hline \multirow[t]{2}{*}{ AT 1590000} & 00035 & FEDC \\
\hline & 00170 & Fusion Remote Handling Demonstratio \\
\hline HAO201010 & 000801 & Dosimetry for Human Exposures \\
\hline \multirow[t]{10}{*}{ HAO202010 } & 000143 & Fission Neutrons $\varepsilon$ Gamma Rays \\
\hline & 000190 & Radiation Immunology \\
\hline & 003441 & H-Coal Bioassay \\
\hline & 003551 & Interpretation of Cancer Tests \\
\hline & 003552 & Radn Carc-Time Dose Relation \\
\hline & 003955 & Dose Response Relation in Chem Carc \\
\hline & 003957 & Carcinogen Activity in Human Cells \\
\hline & 003958 & solid state RIA in Cocarcinogenesis \\
\hline & 003959 & Chem Carcinogens \& UV Radiation \\
\hline & NOEพ80 & Interferon \\
\hline \multirow[t]{11}{*}{ HAO202020 } & 000173 & Mammalian Biochem Genetics \\
\hline & 000174 & Mammalian Genetics \\
\hline & 000181 & Mammalian Cytogenetics \\
\hline & 001569 & Comparative Mutagenesis \\
\hline & 001570 & Mammalian Chem Mutagenesis \\
\hline & 002527 & Genetic effect of plutonium \\
\hline & 003555 & Freezing Mouse Mutants \\
\hline & 003968 & Mammalian Cell Genetic Toxicology \\
\hline & 003969 & Medical $\&$ Molecular Genetics \\
\hline & 003970 & Mechs of Mamm Mutagenesis \\
\hline & 003971 & Genetic Basis of Mutagenesis \\
\hline \multirow[t]{3}{*}{ HAO202030 } & 000183 & Mammalian Gametogenesis \\
\hline & 002362 & Chemical Toxicology \\
\hline & 003980 & Biostatistics $\varepsilon$ Biomathematics \\
\hline \multirow[t]{4}{*}{ HAO2 203010} & 000608 & Transport, Fate, $\varepsilon$ Effs of Ener Eff \\
\hline & $\begin{array}{l}000681 \\
000690\end{array}$ & $\begin{array}{l}\text { Envir Effs of Uran Enrich Facils } \\
\text { Radionuclides in the Environment }\end{array}$ \\
\hline & $\begin{array}{l}002528 \\
003356\end{array}$ & $\begin{array}{l}\text { Radionuclide in the coastal zone } \\
\text { Comparative Environmental Chemistry }\end{array}$ \\
\hline & 009029 & Hydrologic Transport of Trace Elem \\
\hline \multirow[t]{5}{*}{ HAO203020 } & 000609 & Ecological Processes in SE Systems \\
\hline & 001693 & Envir Fate and Effs of org Mixtures \\
\hline & 003546 & H Coal Environmental project \\
\hline & 003944 & Terrestrial Effects of Energy Dev. \\
\hline & 003945 & Effs on vegetation of Gas Pollutant \\
\hline \multirow[t]{2}{*}{ HA0203050 } & 000929 & National Environmental Research Par \\
\hline & 002936 & Dev of Guidelines for Montr \\
\hline \multirow[t]{3}{*}{ HAO204010 } & 001710 & Char and Repository of synFuels \\
\hline & 001722 & Chem Related to the Toxicol props \\
\hline & 003469 & Coal Liquefaction: Pollutant char. \\
\hline \multirow[t]{3}{*}{ HAO204020 } & 001624 & Atmosphere-Canopy Interactions \\
\hline & NOEW 42 & Dry Deposition Calibration \\
\hline & NOEW6 6 & Control of Trit Exposure in Reacs \\
\hline \multirow[t]{2}{*}{ HAO 204030} & 000714 & Health Physics Research Reactor \\
\hline & 000717 & Medical Physics $\varepsilon$ Internal Dos \\
\hline
\end{tabular}


Table SD.2 (continued)

\begin{tabular}{|c|c|c|}
\hline B \& $R$ code & WPAS No. & WPAS title \\
\hline & 001608 & Resonance Ionization spectroscopy \\
\hline & 001707 & Dosimetry for New Energy sys Poll \\
\hline & 004169 & Environ. E Personnel Monitoring \\
\hline & 004170 & Anal Chem of Isomers and Intractabl \\
\hline & 004273 & Hiroshima/Nagasaki Reevaluation stu \\
\hline \multirow[t]{6}{*}{ HA0204060 } & 000722 & Atomic \& Molecular Physics \\
\hline & 001706 & Microdosim \& Biol Modeling \\
\hline & 004165 & studies-Phys Param-Health Protectn \\
\hline & 004166 & Chemistry in the Atmosphere \\
\hline & 004167 & Poll Ion Formation and Atmos clust \\
\hline & 004168 & Surf Inter $\varepsilon$ Ion Part Accretion \\
\hline \multirow[t]{7}{*}{ HAO205000 } & 001669 & Global Carbon Cycle \& Climate \\
\hline & 003160 & Bioclimatology of Energy Impacts \\
\hline & 003457 & Elevated $\mathrm{CO} 2$ Effects on Terrest \\
\hline & 003547 & Soil Carbon in the Global Carbon $C y$ \\
\hline & 003781 & Sensitivity Analysis of CO- 2 \\
\hline & 003939 & Carbon Dioxide Info Center \\
\hline & 004181 & Carbon Cycle Prog. Mgmt. \\
\hline \multirow[t]{3}{*}{ HAO206000 } & 003462 & HIth and Env Impacts of Coal Iiquef \\
\hline & $\begin{array}{l}003932 \\
004182\end{array}$ & $\begin{array}{l}\text { Water Chlorination Conference } \\
\text { LMFBR Health Risk Assessment }\end{array}$ \\
\hline & 004262 & Risk Barriers Survey \\
\hline HAO281000 & 00000 & Fuel Fabrication-HPRR Change \\
\hline \multirow[t]{27}{*}{ HB 0100000} & 000158 & Growth \& Regeneration \\
\hline & 000162 & Mechanism of Radiation Lethal \\
\hline & $\begin{array}{l}000165 \\
000167\end{array}$ & $\begin{array}{l}\text { Nucleic Acids in Pathogenesis } \\
\text { Theoretical } \& \text { Applied Cryobiol }\end{array}$ \\
\hline & 000169 & $\begin{array}{l}\text { Enzyme Regulation } \\
\text { Eneoretion }\end{array}$ \\
\hline & 000177 & Drosophila Cytology $\&$ Genetics \\
\hline & 000179 & Microbial Mutagenesis $\varepsilon$ Cell \\
\hline & 000184 & Effs and Uses of Chromosome Aberrat \\
\hline & 000283 & Environmental Insults to DNA \\
\hline & 000284 & Chromosome Chemistry \\
\hline & 000607 & Systs Processes in Landscape Ecolog \\
\hline & 000718 & Transport \& Surface Physics \\
\hline & 000719 & Chemical Physics studies \\
\hline & 000720 & Liquid $\varepsilon$ Submicron Physics \\
\hline & 000721 & Physics of Solids \& Macromolecules \\
\hline & 001472 & Protein Chemistry \\
\hline & 001476 & Molecular Aspects of Radiation \\
\hline & 001603 & Physicochem Props of Chem Polluts \\
\hline & 001610 & Energy pathways in Irrad Gases \\
\hline & 001699 & Gene Expression in Carcinogenesis \\
\hline & 001701 & Carcinogen-Cell Genome Interact \\
\hline & 002360 & studies-Tumor Cell Immunology \\
\hline & 002368 & Reg of Membrane Transport system \\
\hline & 003236 & Mechanisms of Damage $\varepsilon$ Repair \\
\hline & 003763 & Dev Tunable vuV spectroscopic Techs \\
\hline & 003947 & Nucleic Acid Biochemistry \\
\hline & 004277 & Electronic Autofluorography \\
\hline & NOEพ98 & DNA-Carcinogen Interactions \\
\hline НВ 0201000 & 000982 & 86-In Cyclotron Tech Support \\
\hline & $\begin{array}{l}001161 \\
003765\end{array}$ & $\begin{array}{l}\text { Nuc Medicine E Biomed Technology } \\
\text { Radisotope Prod Tech Dev }\end{array}$ \\
\hline НВ0281011 & 00000 & Radioactive Isotopes-Change \\
\hline
\end{tabular}


Table SD.2 (continued)

\begin{tabular}{|c|c|c|}
\hline B \& $R$ code & WPAS No. & WPAS title \\
\hline НВ 0281012 & $\begin{array}{l}00000 \\
003264\end{array}$ & $\begin{array}{l}\text { Non-EM Stable Isotopes-Change } \\
\text { Isotope Enrichment--Biomedical }\end{array}$ \\
\hline KA0101000 & 00001 & High Energy Physics \\
\hline & 00002 & High Energy Accel Shield studies \\
\hline KB0101000 & 99999 & Unassigned Uncosted Bal $9 / 30 / 82$ \\
\hline KBO201000 & 00012 & Heavy Ion Nuclear Research \\
\hline \multirow[t]{3}{*}{$\mathrm{KB} 0202000$} & 00016 & HHIRF - Operations \\
\hline & 00017 & HHIRF User Support \\
\hline & 00018 & Heavy Ion Laboratory Development \\
\hline KBO300000 & 00020 & Theoretical Nuclear Physics \\
\hline KBO401000 & $\begin{array}{l}00022 \\
00025\end{array}$ & $\begin{array}{l}\text { Light Ion Nuclear Physics Research } \\
\text { Neutron Capture }\end{array}$ \\
\hline \multirow[t]{4}{*}{ KC0101020 } & 00003 & Imp in Med-En Trans Code \\
\hline & $\begin{array}{l}00004 \\
00005\end{array}$ & $\begin{array}{l}\text { Spectra of Fission Neutrons } \\
\text { Operations - ORELA }\end{array}$ \\
\hline & 00006 & Nucl Data-Fusion $\varepsilon$ Fission React \\
\hline & 00008 & Neutron Reactions \\
\hline KC0101030 & 00002 & Nuclear Data Project \\
\hline $\mathrm{KC} 0102010$ & 00013 & Electromag Isotope separation \\
\hline \multirow[t]{2}{*}{ KCO 102020} & 00014 & High Flux Isotope Reactor \\
\hline & 00015 & Transuranium Element Processing \\
\hline KCO 102030 & 00012 & Chem of Transuranium El \& Comp \\
\hline \multirow[t]{3}{*}{ KCO201010 } & 00018 & Theoretical studies of Metals and $A$ \\
\hline & 00019 & X-ray Research Using Synchro source \\
\hline & 00020 & Anal \& High Voltage Electron Micros \\
\hline \multirow[t]{2}{*}{$\mathrm{KCO} 201020$} & 00021 & Deform \& Fract of Metals $\varepsilon$ Alloys \\
\hline & 00026 & Mech Prop of Ceramics \\
\hline KC0201030 & 00022 & Solid State Reacts \& phys Props \\
\hline KC0201040 & 00023 & Radiation Effects \\
\hline \multirow[t]{3}{*}{ KCO201050 } & 00024 & Fundamentals of Welding $\varepsilon$ Joining \\
\hline & 00025 & High-Temp Alloy Design \\
\hline & 00124 & Research in Ceramics Processing \\
\hline \multirow[t]{4}{*}{ KC0202010 } & 00027 & Interatomic Interact in cond syst \\
\hline & 00028 & Prop-Defects, Supercond, Hydrides \\
\hline & 00029 & Support for Neutron Users' Program \\
\hline & 00030 & Assist to sol st Phys \& Matls Chem \\
\hline \multirow[t]{7}{*}{$\mathrm{KC} 0202020$} & 00031 & Phys Prop of superconductors \\
\hline & 00032 & Phytophys Proc-Solar Energy Conv \\
\hline & 00033 & Fund Aspects of Metal Fracture \\
\hline & 00038 & Scatter of synchrotron Radiation \\
\hline & 00134 & High Temp Ceramic Materials \\
\hline & 00136 & Prep $\varepsilon$ Char of Res Matls \\
\hline & 00137 & Small-Angle $x$-Ray scattering \\
\hline $\mathrm{KC} 0202030$ & 00039 & Theory of Condensed Matter \\
\hline \multirow[t]{2}{*}{$\mathrm{KCO} 202040$} & 00040 & X-Ray Diferaction E Electron Micros \\
\hline & 00044 & Gases in Metals \\
\hline \multirow[t]{5}{*}{ KC0202050 } & 00017 & R\&D - Isotope Research Matls Prep \\
\hline & 00042 & Surface Physics $\&$ Catalysis \\
\hline & 00142 & Surf Mod E Char Fac \& Collab Res ct \\
\hline & 00143 & Ion Beam Analysis $\varepsilon$ Ion Implant \\
\hline & 00144 & Radioactive Waste storage \\
\hline $\mathrm{KCO} 203010$ & 00045 & Chem structure of Energy Rel Mat \\
\hline $\mathrm{KC} 0203020$ & 00046 & Thermodyn \& Sens Ana of En Rel sys \\
\hline
\end{tabular}


Table SD.2 (continued)

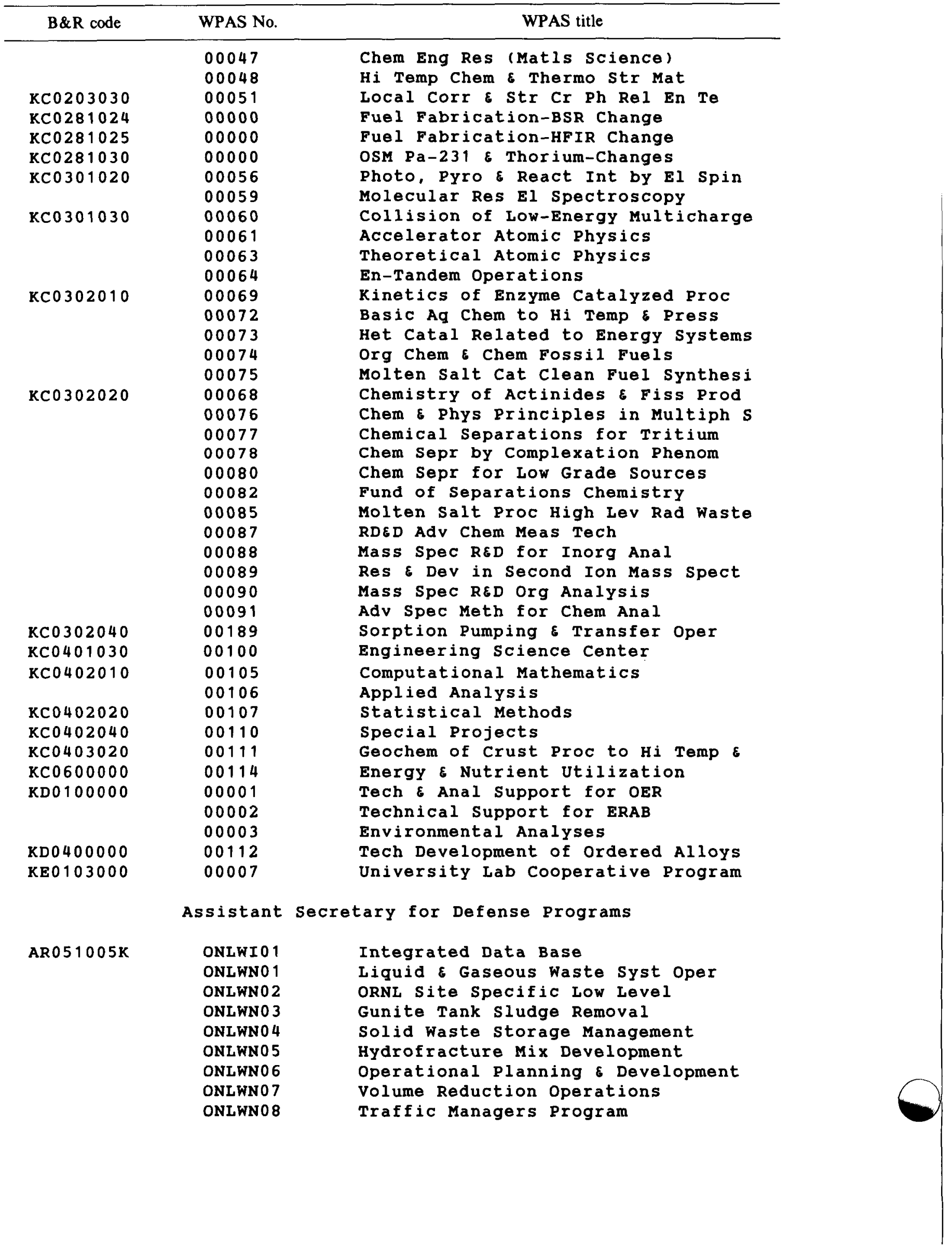


Table SD.2 (continued)

\begin{tabular}{|c|c|c|}
\hline$B \& R$ code & WPAS No. & WPAS title \\
\hline & ONLWN 10 & Mgmt Metal Waste ORO sites \\
\hline & ONLWN 13 & Development of LLW Disposal Fac. \\
\hline \multirow[t]{5}{*}{ AR0510100 } & ONLWDO 5 & FPDL Decommissioning \\
\hline & ONLWDO 8 & Defense Surplus Fac Surveil \\
\hline & ONLWD 12 & Metal Recovery Bldg Decommissioning \\
\hline & ONLWD 13 & ILW Transfer Line Decom \\
\hline & ONLWD 16 & Disposition surplus ORNL Facilities \\
\hline \multirow[t]{2}{*}{ ARO 0515050} & ONLWAO 5 & Carbon-14 Immobilization \\
\hline & ONLWAO 8 & FTF Quality Assurance \\
\hline AR0 515100 & 99999 & Unassigned Uncosted Balance $9 / 30 / 82$ \\
\hline \multirow[t]{5}{*}{ AR0 0515150} & ONLWLO 1 & LL Waste Program Management \\
\hline & ONLWLO9 & Corrective Measures Technology \\
\hline & ONLWL 14 & Shallow Land Burial Technology \\
\hline & ONLWL 32 & Shallow Land Burial Handbook \\
\hline & ONLWL 33 & Corrective Measures Handbook \\
\hline \multirow[t]{3}{*}{ AR0 515200} & ONLWT 10 & Instrumentation support \\
\hline & ONLWT 16 & RH Tru waste Certification \\
\hline & ONLWT 22 & Inventory Work off plan \\
\hline AR0 015250 & ONLWBO 1 & Krypton-85 Light Developnment \\
\hline AR0 525000 & ONLWRO 1 & Defense Waste Trans studies \\
\hline GBO 103010 & 99999 & Unassigned Uncosted Balance $9 / 30 / 82$ \\
\hline GBO381042 & 00000 & Spec React Matls-Boron-10 Change \\
\hline GC0102050 & OR00002 & Sensitive Tech - Proliferation \\
\hline \multirow[t]{2}{*}{ GCO 102070} & ORO0001 & Nuclear Fuel Cycle Workshop \\
\hline & ORGC2 & Isotopes Separation Tech \\
\hline GD0201010 & OR00002 & NLO CASE STUDY \\
\hline GD0203000 & OR04011 & Micro-Sampling Resin Bead Mass Spec \\
\hline GE0221010 & ON5419B & Inventory--Heavy Element production \\
\hline \multirow[t]{2}{*}{ GE0 348040} & ON5419A & 233 U Dispensing Facility \\
\hline & ON5519A & Con-Ed Conversion \\
\hline \multirow[t]{2}{*}{ GE0348060 } & 00001 & Management DOE-DP UOR System \\
\hline & 99999 & Unassigned Uncosted Balance $9 / 30 / 82$ \\
\hline GE0381044 & 00000 & Sp Reac Matls-Hvy Water Change \\
\hline GE0 381054 & 00000 & OSM Am-241,Np-237,U-234-Inv Changes \\
\hline Assistant & Secretary for Env. & - Protection, safety $\&$ Emerg. Prep \\
\hline EF 0700000 & 99999 & Unassigned Uncosted Bal $9 / 30 / 82$ \\
\hline HAO 101010 & 003474 & Envir Tech Assist and Guidelines \\
\hline \multirow[t]{2}{*}{ HAO 101020} & 002975 & OEA - Envir. POlicy \& Analysis \\
\hline & 003921 & Equipment support to spain \\
\hline HAO 108061 & ESO10 & Computation Performance Assessment \\
\hline HAO 108062 & 600097 & Emergency Technology \\
\hline HAO 108081 & 003740 & Tech Assist for Spain \\
\hline HAO 108082 & 800477 & Radiological Surveys \\
\hline HAO 108084 & $\operatorname{ES} 090$ & Tech. Support Hazardous Waste Manag \\
\hline SA0101000 & 99999 & Unassigned Uncosted Bal $9 / 30 / 82$ \\
\hline UBO201000 & 99999 & Unassigned Uncosted Bal $9 / 30 / 82$ \\
\hline \multirow[t]{2}{*}{ UEO401000 } & 99999 & Unassigned Uncosted Bal $9 / 30 / 82$ \\
\hline & Federal Energy & Regulatory Commission \\
\hline VI0104010 & 00002 & Wheeling \\
\hline \multirow[t]{2}{*}{ VPO000000 } & 00001 & FERC support \\
\hline & 00002 & Susitna Hydro Project Need for Powe \\
\hline
\end{tabular}


Table SD.2 (continued)

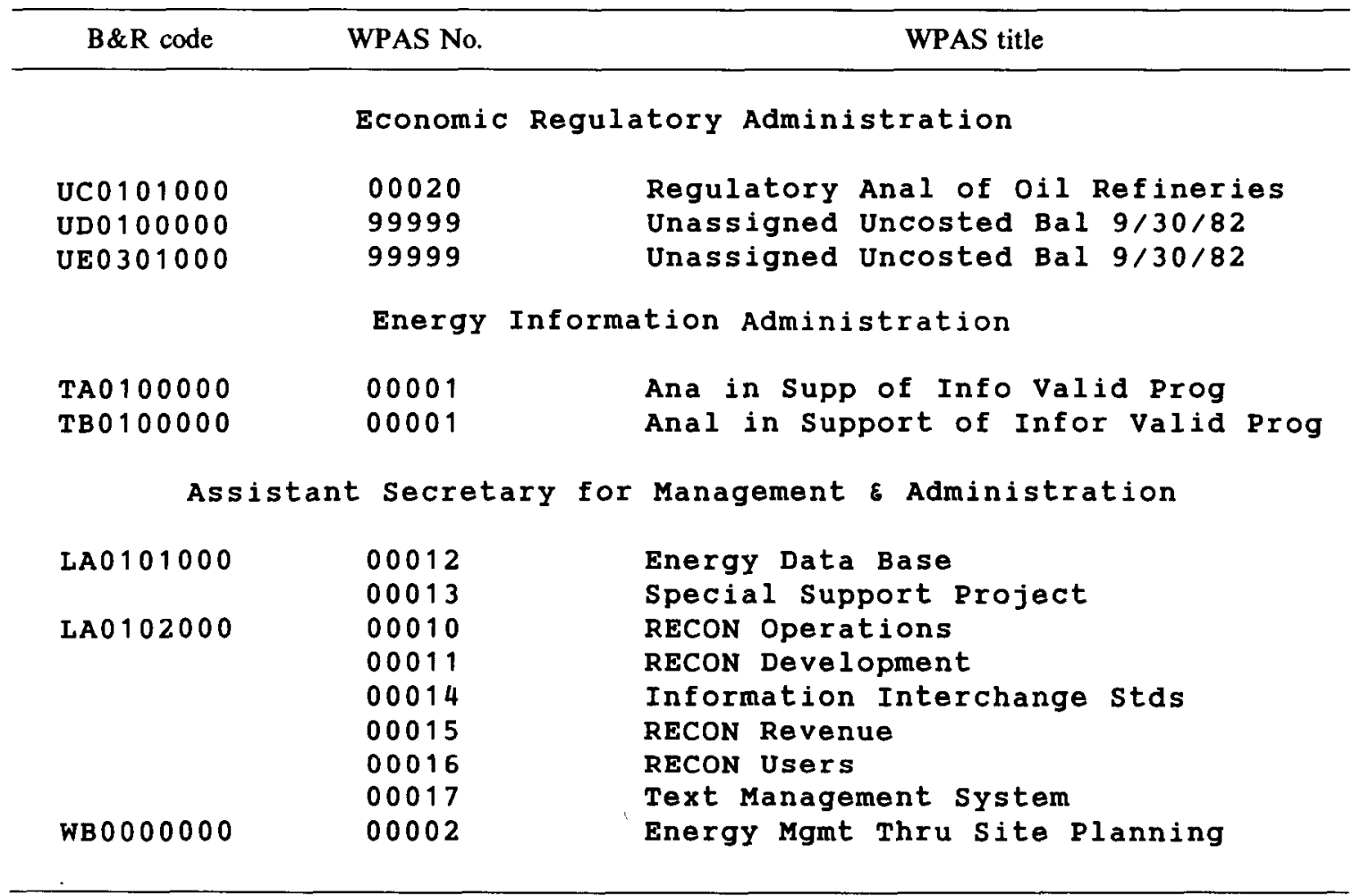

${ }^{a}$ ORNL's base budget submittal, April 1983. 
Table SD.3. Expenditures on behalf of historically black colleges ( $S$ in Thousands)

\begin{tabular}{lccccccc}
\hline & FY 1983 & FY 1984 & FY 1985 & FY 1986 & FY 1987 & FY 1988 & FY 1989 \\
\hline $\begin{array}{l}\text { Total estimated } \\
\text { expenditures }\end{array}$ & 22 & 347 & 200 & 200 & 200 & 200 & 200 \\
\hline
\end{tabular}

Table SD.4. Phases of R \& D analysis

( $\$$ in Millions-total $\mathrm{BO}$ )

\begin{tabular}{lrrr}
\hline & FY 1983 & FY 1984 & FY 1984 \\
\hline Research & 198.6 & 222.9 & 243.6 \\
Exploratory Development & 33.1 & 37.4 & 38.7 \\
Advanced Development & 56.3 & 56.8 & 58.5 \\
Engineering Development & 40.6 & 48.1 & 50.5 \\
\hline
\end{tabular}




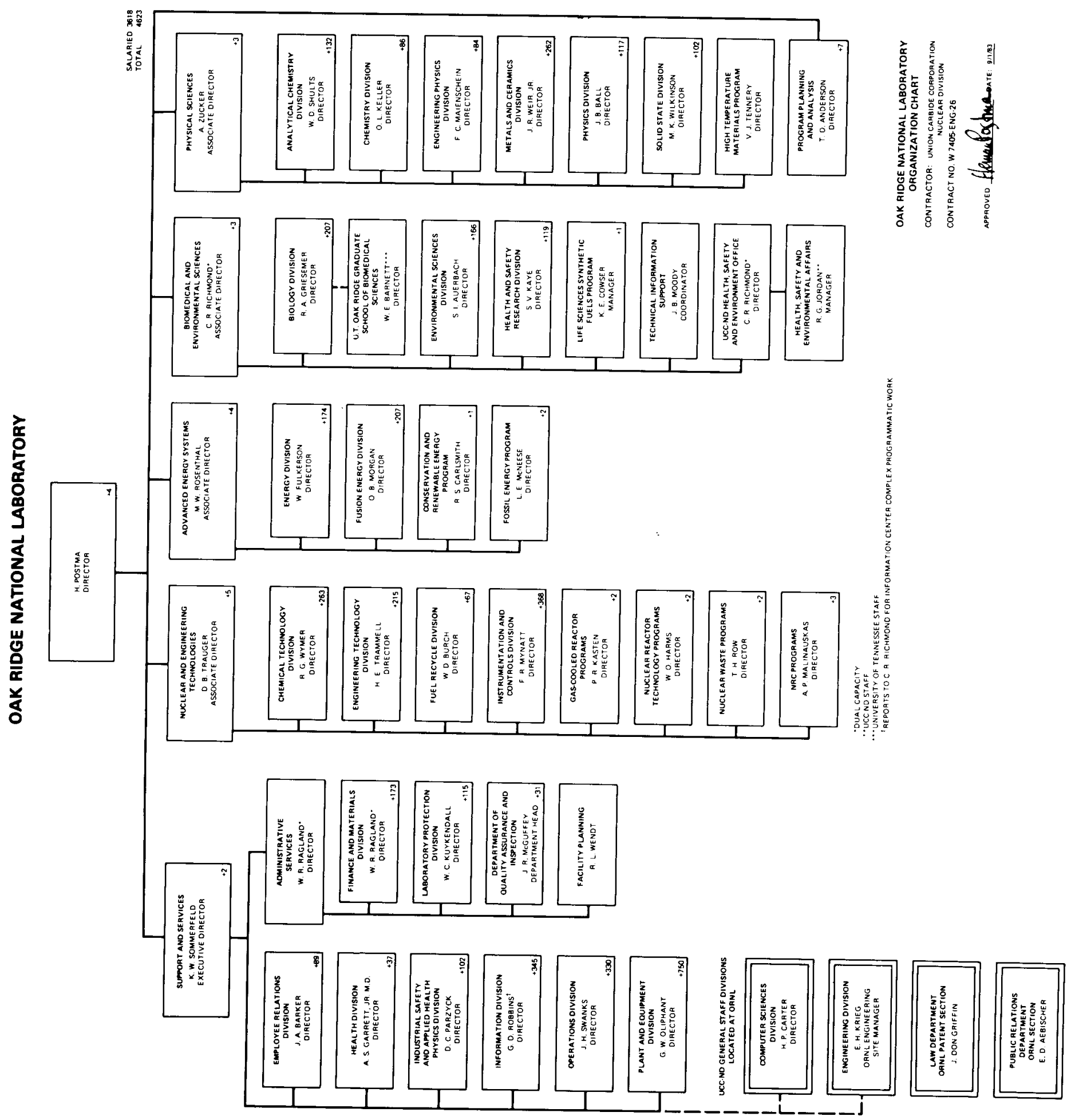

